УНИВЕРЗИТЕТ У БЕОГРАДУ

ФАКУЛТЕТ БЕЗБЕДНОСТИ

СВЕТЛАНА С. СТАНАРЕВИЋ

КОНЦЕПТ БЕЗБЕДНОСНЕ КУЛТУРЕ

И ПРЕТПОСТАВКЕ

ЊЕГОВОГ РАЗВОЈА

ДОКТОРСКА ДИСЕРТАЦИЈА

Београд, 2012 


\section{UNIVERSITY OF BELGRADE \\ FACULTY OF SECURITY STUDIES}

SVETLANA S. STANAREVIĆ

\section{THE CONCEPT OF SECURITY CULTURE AND ASSUMPTIONS OF ITS DEVELOPMENT}

DOCTORAL DISSERTATION

Belgrade, 2012 
Комисија

Председник: Др Радомир Милашиновић, редовни професор, Универзитет у Београду, Факултет безбедности Ментор: Др Миленко Бодин, доцент, Универзитет у Београду, Факултет безбедности

Члан: Др Љубомир Стајић, редовни професор, Универзитет у Новом Саду, Правни фракултет

Члан: Др Зоран Кековић, редовни професор, Универзитет у Београду, Факултет безбедности

Датум одбране: 


\section{Концепт безбедносне културе и претпоставке његовог развоја}

\section{Резиме}

У раду се разматрају могући правци теоријског заснивања концепта безбедносне културе на основу анализе различитих теоријских приступа његовим конститутивним елементима - културе и безбедности. Као прво, након представљања различитих теоријских оквира унутар антрополошке димензије концепта културе, издвојена је хуманолошка теоријска перспектива развоја културе - од првобитног разумевања културе као услова опстанка, до савременог, који је види као услов развоја и добробити. На том путу се развијао и интерес безбедности, као један од суштинских интереса који покреће савременог човека.

Анализа појма културе помогла нам је да се разјасне симболичка значења и позитивне вредности, имплицитне и експлицитне, у одређеном начину живота у извесној култури. Анализа обухвата и сагле́дање елемената начина живота (који за присталице другачијих одређења заправо и не спадају у област културе); организацију државних институција; структуру институција које изражавају или владају друштвеним односима; карактеристичне форме којима припадници друштва комуницирају; трагове креативне људске делатности у институцијама и облицима понашања.

Такође је важно да се представе елементи који уобличавају (националну) културу, као што су симболи, обичаји, ритуали и вредности, али и елементи који обележавају поље у оквиру којег се може разматрати национална култура да би се ближе одредили не само утемељени процеси који је стварају, већ и категорије које ремете њен поредак, а огледају се у промени, традицији и идентитету. Затим следи представљање националне културе као националног и јавног интереса, што се испољава на начин који артикулише вредности, перцепцију добробити и перцепцију развоја и угрожености.

С друге стране, поред наглашавања значаја интердисциплинарног проучавања, посебно је разматран хуманолошки и културолошки модел концептуализације безбедности који је дао полазну основу за разраду могућности његове 
измењене употребе у оквиру концепта безбедносне културе с циљем заштите и одржавања добробити појединца, друштва и државе. Стога други сегмент обухвата дефинисање теоријског упоришта појма безбедности, који се затим идентификовао и артикулисао у структуралној вези националне културе и националне безбедности.

У раду су анализирани и представљени различити теоријски приступи безбедности, који имају одређене рефлексије на разумевање овог појма кроз појмове сигурности, извесности и очувања егзистенције. Анализа појма безбедности одвијала се у контексту могућности да се он развије, прво, као посебна људска потреба, а затим као интерес у контексту културних потреба, примењујући културолошки приступ, уобличен категоријом националне безбедности. Овај сегмент је приказао и артикулацију културе у концептима безбедности, те на нивоима рефлексије који се огледају кроз призму личности, друштва, заједнице или ентитета; и осликао културу као национални безбедносни интерес.

Анализирајући посебно концепт идентитета и његове релације према култури и безбедности, покушали смо да укажемо на чињеницу да промене до којих долази у друштвеним односима током конституисања идентитета и прерастања из једног облика у други - дефинишу и оснажују социјалне капацитете за утврђивање елемената националне културе који ће се трансформисати у безбедносну културу.

Коначно, трећи сегмент рада анализира теоријска исходишта у којима се проналазе могуће сличности, али и размимоилажења са концептом безбедносне културе, који се у новије време интензивно развија. У овом делу приказани су конституисање и развој појма и термина безбедносна култура, као и промене које су се одсликале у његовом концептуалном развоју. То нам је помогло да се утврди садржај и суштина концепта безбедносне културе, његова обележја која имају синтетичка, трансферна и развојна својства. Даље је представљена безбедносна култура као фактор развоја националне безбедности, укључујући два битна процеса: први, као трансфер националне културе у безбедносну културу, и други, као трансфер националне безбедности у безбедносну 
културу. Безбедносну културу смо сагледали и у светлу регионалних, интернационалних и глобалних процеса у свету, као и кроз могућност да се институционално развија у односу на друштвене интеграције, на државу и у оквиру међународних односа.

Концепт безбедносне културе превасходно се анализира унутар антрополошкохуманолошког приступа разумевању концепта културе, начина на који се артикулише феномен идентитета из поља културе у поље безбедности, затим конституише интерес безбедности и утврђује однос националне културе и националне безбедности.

Методологија и модели истраживања безбедносне културе могу се представити на основу више приступа, а у раду су издвојени: приступ организационе културе, приступ са аспекта супкултуре, приступ са аспекта социјалног капитала и хуманолошки приступ. Да би концепт могао „живети“, важно је фокусирати се и на његов развој и практичну примену, тако да су се издвојили фактори који то омогућавају, а сматрамо да се међу најбитније могу уврстити: образовање, обавезивање, контрола и примена стандарда̂.

У оквиру завршног поглавља су систематизовани резултати истраживања и синтетизовани у закључак о природи теоријских основа безбедносне културе. Размотрен је научни и шири друштвени значај одређивања теоријских полазишта безбедносне културе.

Кључне речи: култура, национална култура, вредности, идентитет, безбедност, национална безбедност, безбедносна култура, национални интереси, развој, добробит

Научна област: друштвено-хуманистичке науке

Ужа научна област: студије безбедности

УДК број: 351.78:316.7 


\title{
The concept of security culture and assumptions of its development
}

\begin{abstract}
This dissertation treats potential directions for the theoretical foundation of the security culture concept on the basis of analyis of various theoretical approaches towards its constitutive elements - culture and security. Firstly, after presenting multifarious theoretical frameworks within the anthropological dimension of the culture concept, the humanological theoretical perspective of culture development is singled out - from the original comprehension of culture as a precondition of survival to the contemporary one, that conceives it as an assumption of development and welfare. Following that way, the security interest has also developed, as one among the essential interests which move the contemporary man.
\end{abstract}

The analysis of the culture concept have helped us to elucidate symbolical meanings and positive values, implicit and explicit ones, in a certain way of life in some culture. The analysis comprises, too, the recognition of elements of the way of life (that in fact, for supporters of other determinations, do not fall into the domain of culture); the organization of state institutions; the structure of institutions which express or dominate social relations; typical forms through which members of society communicate among themselves; the traces of creative human activity in institutions and modes of behaviour.

It is also important to present the elements that shape (national) culture, such as symbols, customs, rites and values, as well as elements which signify the field within which national culture may be examined in order to define more closely founded processes that generate it, but also the categories which disturb its order, and which reflect themselves in change, tradition and identity. Thereafter, it follows a review of national culture as a national and public interest, which manifests itself in the way which articulate values, the perception of welfare and the perception of development and endangerment.

On the other hand, besides stressing the importance of interdisciplinary investigation, the humanological and culturological model for conceptualization of security is especially discussed, which supplied the initial basis for the elaboration of potentials 
of its transformed use within the security culture concept, having in mind the protection and preservation of welfare of individual, society and state. Thus, the second segment encompasses defining of theoretical support for the security concept, which has thereafter identified and articulated itself in the structural connection of national culture and national security.

In this thesis, various theoretical approaches toward security are analyzed and presented, which have certain repercussions on the conception of this notion through the concepts of security, certainty and the preservation of existence. The analysis of the security concept is performed in the context of possibility of its development, firstly, as a separate human need, and then as an interest in the context of cultural needs, applying the culturological approach, shaped by the category of national security. This segment has showed, too, articulation of culture in security concepts, as well as on the levels of reflection which are manifested through personality, society, community or entity; and it has depicted culture as the national security interest.

Analyzing especially the concept of identity and its relationships towards culture and security, we have tried to point to the fact that changes which emerge in social relations during the process of constituting identity and developing from the one form to another - define and strenghten social capacities for establishing the elements of national culture which will be transformed into security culture.

Finally, the third segment of the dissertation analyzes theoretical departures in which possible similarities are found, but also disagreements with the concept of security culture, which develops intensively in recent times. In this part, the genesis and development of the concept and term of security culture are described, as well as shifts that have reflected in its conceptual evolution. It have aided us to establish the content and essence of the security culture concept, its features that have synthetical, transpositional and developmental attributes. Furthermore, security culture is presented as a factor of development of national security, including two substantive processes: the first one, as the transfer of national culture into security culture, and, secondly, as the transfer of national security into security culture. We have also interpreted security culture in the light of regional, international and global processes 
worldwide, as well as through possibility to develop itself institutionally in the relation with social integrations, state and in the framework of international relations. The concept of security culture is analyzed primarily within the anthropologicalhumanological approach towards comprehension of the culture concept, within the manner in which the identity phenomenon have articulated itself from the realm of culture into the domain of security, then the way the security interest is constituted and the relation between national culture and national security is established.

The methodology and models for examination of security culture can be represented on the basis of various approaches, and we single out the following: the organizational culture, the approach from the perspective of subculture, the approach from the viewpoint of social capital and humanological approach. In order for the concept to "live", it is important to focus on its development, as well as on its practical implementation, so we have distinguished the factors which enable it, while we consider among the most significant ones: education, obligation, control and the application of standards.

Within the concluding chapter, the results of investigation are systematized and synthesized into an assessment on the nature of theoretical foundations of security culture. The scientific and wider social significance of theoretical vantage points of security culture is discussed, too.

Keywords: culture, national culture, values, identity, security, national security, security culture, national interests, development, welfare

Scientific domain: social sciences and humanities

Scientific specialty: security studies

UDK number: 351.78:316.7 


\section{САДРЖАЈ}

УВОД

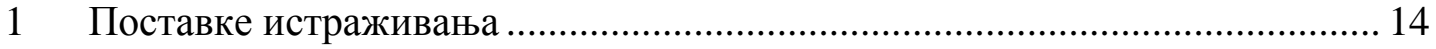

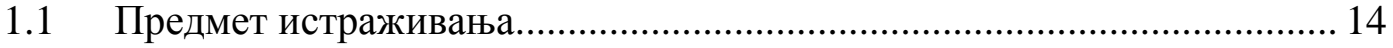

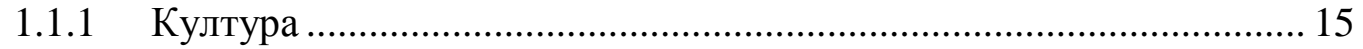

1.1.2 Национална култура …………………………………………….... 22

1.1.3 Идентитет …………………………………………………….... 23

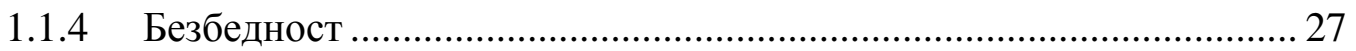

1.1.5 Национална безбедност, национална култура и национални

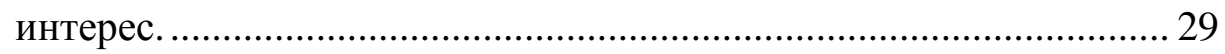

1.1.6 Безбедносна култура......................................................................... 30

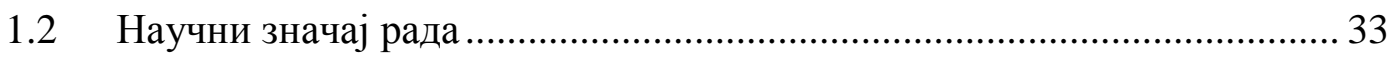

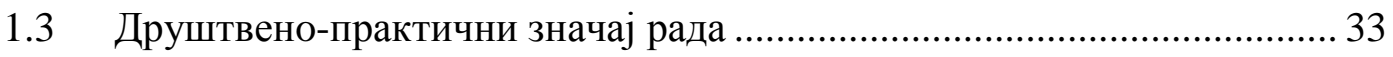

1.4 Теоријско-методолошки апарат ............................................................. 34

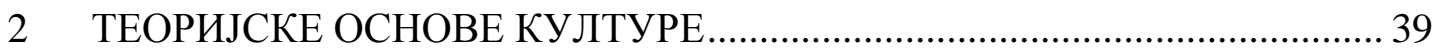

2.1 Појам културе и различити теоријски приступи..................................... 40

2.1.1 Антрополошки приступ ................................................................... 47

2.1.2 Теорије културне еволуције........................................................... 52

2.1.3 Еколошки приступ .......................................................................... 58

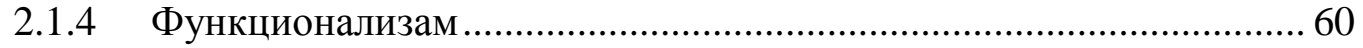

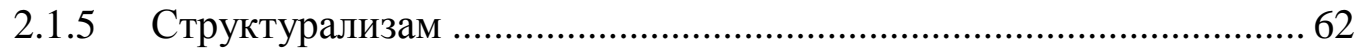

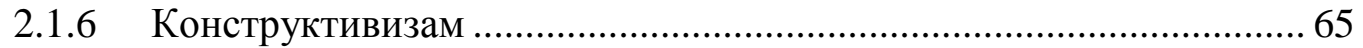

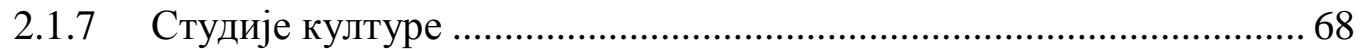

2.1.8 Хуманолошки поглед на културу као теоријска перспектива....... 72 
2.2.1 Културни обрасци као фактори идентитета и разлике..................... 82

2.2.2 Заснивање вредности у оквиру једне културе …............................8 89

2.2.3 Култура - доминантна и/или маргинална својства ........................ 91

2.2.4 Културне разлике као фактор стабилности или социјалне

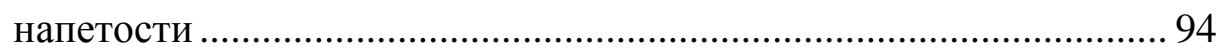

2.2.5 Мултикултурализам ................................................................. 98

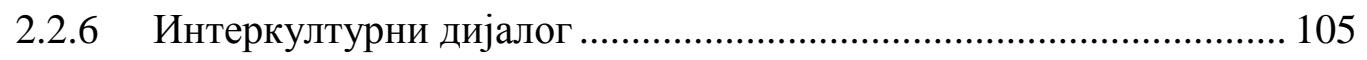

2.3 Уобличавање (националне) културе................................................. 107

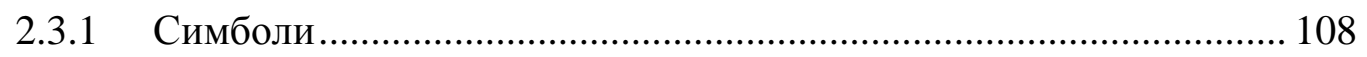

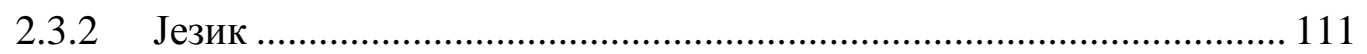

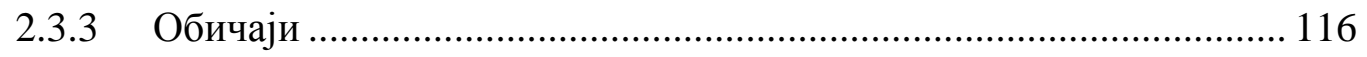

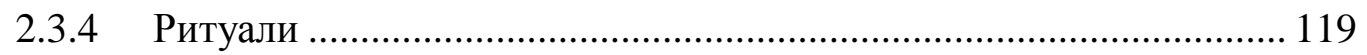

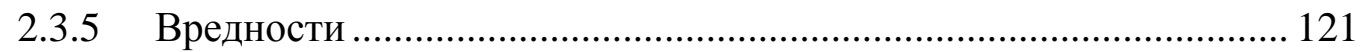

2.4 Основи националне културе........................................................... 123

2.4.1 Појам и значење ......................................................................... 123

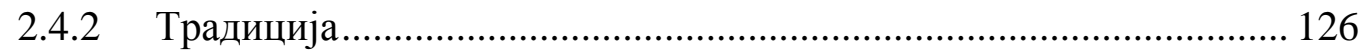

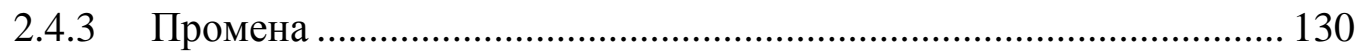

2.4.4 Идентитет/различитост …............................................................. 132

2.5 Национална култура као национални и јавни интерес ....................... 135

2.5.1 Артикулација вредности ......................................................... 137

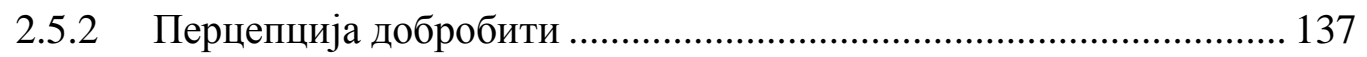

2.5.3 Перцепција развоја и угрожености ............................................ 138

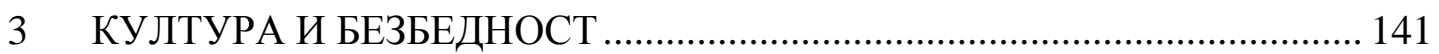

3.1 Теоријски основи безбедности................................................... 141 
3.1.1 Појам и дефиниције безбедности ................................................ 142

3.2 Артикулација културе у концептима безбедности ............................... 160

3.2.1 рај Хладног рата и стварање нових идентитета укорењених у

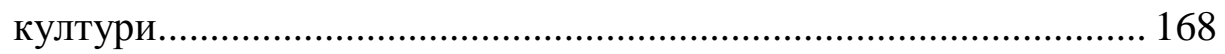

3.2.2 Однос културе, идентитета и безбедности..................................... 170

3.2.3 Култура и систем вредности као основ сарадње у безбедности . 176

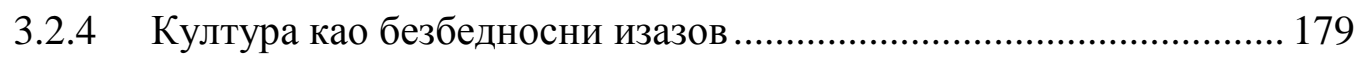

3.2.5 Култура као исходиште или упориште безбедности..................... 182

3.2.6 Културни обрасци и модели понашања у сфери безбедности .... 190

3.3 Култура и безбедност - нивои рефлексије.......................................... 194

3.3.1 Релације појмова култура и безбедност кроз призму личности.. 195

3.3.2 Пројекције на друштво ............................................................. 197

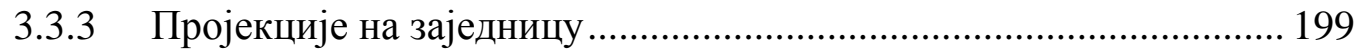

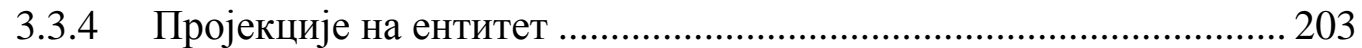

3.4 Култура као национални безбедносни интерес ....................................2 204

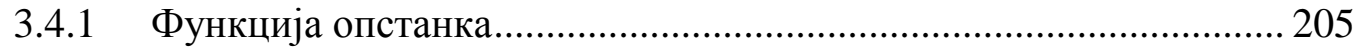

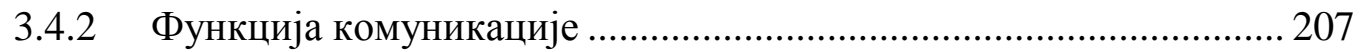

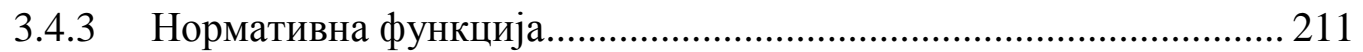

3.4.4 Безбедносно-заштитна функција................................................... 212

3.4.5 Кумулативна функција културе ..................................................... 214

3.5 Национална култура и национална безбедност................................... 217

3.5.1 Различити приступи концепту националне безбедности............... 218

3.5.2 Традиционални приступи .............................................................. 220

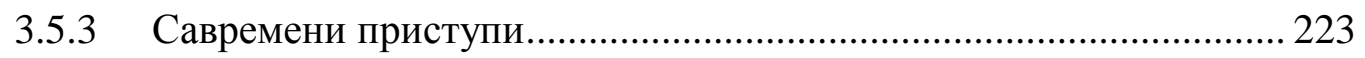

3.5.4 Национална култура као фактор националне безбедности .......... 227 
4.1 Концепт безбедносне културе у различитим контекстима ................. 231

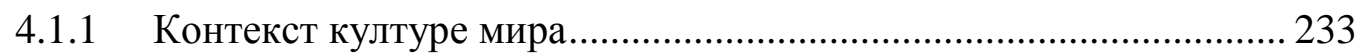

4.1.2 Контекст стратешке културе …….................................................. 236

4.1.3 Контекст политичке културе .................................................... 241

4.1.4 Контекст организационе културе ............................................... 243

4.1.5 Контекст „safety“-културе (културе безбедности и заштите на

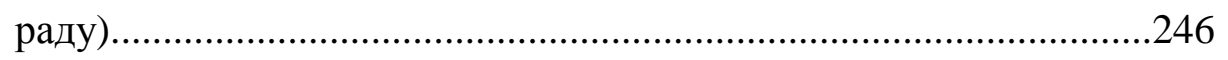

4.1.6 Контекст концепта „друштвене самозаштите“............................ 250

4.2 Појам и основне теоријске поставке безбедносне културе ................ 254

4.2.1 Теоријски основи безбедносне културе......................................... 260

4.2.2 Обележја концепта безбедносне културе ...................................... 278

4.3 Безбедносна култура и процеси у свету .............................................. 283

4.3.1 Регионални/билатерални односи.................................................. 284

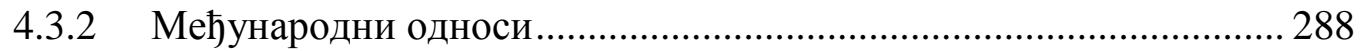

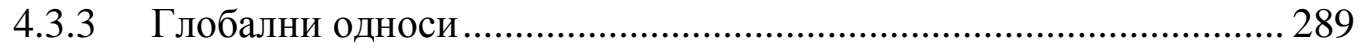

4.4 Безбедносна култура као фактор развоја националне безбедности ... 293

4.4.1 Трансфер националне културе у безбедносну културу ................. 293

4.4.2 Трансфер националне безбедности у безбедносну културу .......... 305

4.5 Институционални развој безбедносне културе ................................... 309

4.5.1 Безбедносна култура и друштвене интеграције............................. 311

4.5.2 Безбедносна култура и однос према држави................................ 312

4.5.3 Безбедносна култура и међународни односи ................................ 314

4.6 Манифестације безбедносне културе .............................................. 314

4.6.1 Безбедносна култура као систем знања ........................................ 315 
4.6.2 Безбедносна култура манифестована кроз ставове ....................... 318

4.6.3 Безбедносна култура као начин понашања ..................................... 320

4.6.4 Безбедносна култура и симболичка комуникација ........................ 322

4.7 Методологија и модели истраживања безбедносне културе ….......... 324

4.7.1 Приступ са аспекта организационе културе ….............................. 325

4.7.2 Приступ са аспекта супкултуре/-а............................................... 327

4.7.3 Приступ са аспекта социјалног и/или културног капитала ........... 329

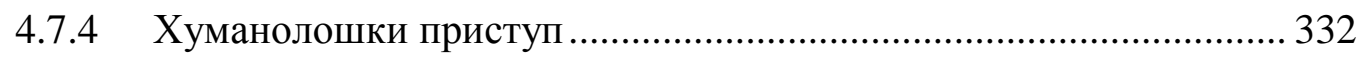

4.8 Развој и примена концепта безбедносне културе................................. 334

4.8.1 Приступ заснован на образовању ................................................ 334

4.8.2 Приступ заснован на обавезивању ................................................ 335

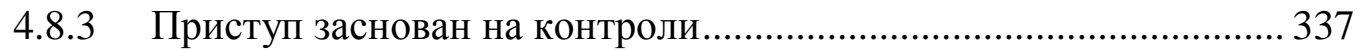

4.8.4 Приступ заснован на примени стандарда̂....................................... 339

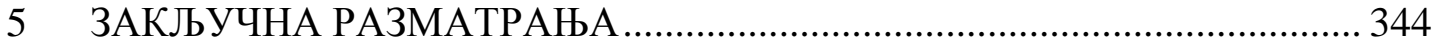

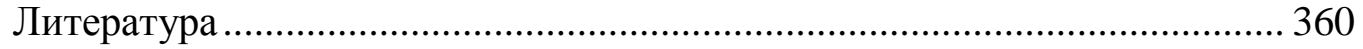

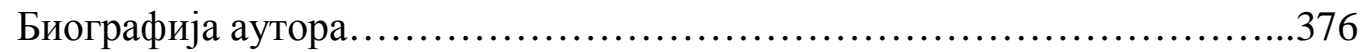

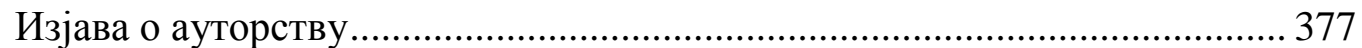

Изјава о истоветности штампане и електронске верзије докторског рада ... 378

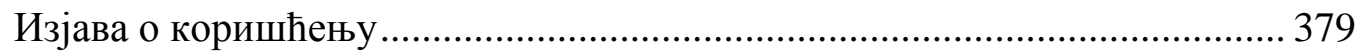




\section{УВОД}

У савременом свету култура представља интегрални део друштвеног и индивидуалног живота. Уколико бисмо покушали да је дефинишемо мером потпуне научне објективности, било би тешко издвојити културу као посебно подручје или предмет посматрања. Такође, објективан суд о култури тешко је успоставити, јер је свако тумачење, па и научно, условљено контекстом у којем настаје. Особине културе - као што су динамичност, хетерогеност и променљивост - смештају је у поље друштвеног, психолошког, политичког, економског и духовног живота људи, али и поље безбедности.

Познати теоретичар културе Рејмонд Вилијамс [Raymond Williams] истицао је у својим радовима чињеницу да је култура „обична“, што, између осталог, може значити да је она део живота свих класа и друштвених група и да обухвата мноштво свакодневних пракси. Такође је приметио да, као сложен организам, тј. као одређени начин живота, култура увек нешто говори, и то кроз заједницу и искуства одређене друштвене групе, која је условљена својим местом у друштвеној структури. ${ }^{1}$ У мноштву различитих приступа и тумачења културе често се издвајају два: један по којем је култура потпуно самосталан и несазнатљив феномен и други, свакако ближи правом стању ствари, по којем је култура релативно самостална, али ипак друштвена појава која има одређених закономерности у свом настанку и развоју, а које су у непосредној вези са другим бројним чиниоцима свеукупног друштвеног развоја и развоја друштвених односа.

Уобичајено је и гледиште да су појединци, групе, заједнице и организације одређени својим културним окружењем. Ово гледиште можемо представити и као размишљање по којем је култура нешто што је „отелотворено у објектима,

1 Рејмонд Вилијамс, „Анализа културе“, у: Сmудије културе - Зборник, Службени гласник, Београд, 2008, стр. 124. 
глумцима, сценама и структурама чији су природа и деловање културолошки организовани. Отелотворена је и у организацијама које имају своје циљеве, техничким структурама, формализованим правилима и конституционалним документима. Отелотворења културе су и склоности, могућности и потенцијалне патологије појединаца.“2

У литератури се често наилази на класично схватање културе, које је представља као стандард естетског савршенства или оно најбоље што је смишљено и изречено на свету. На тај начин се култура види као посвећена област у којој се открива Истина, исказују креативност, дубина и ширина духа, такозвана „висока култура“. Ово виђење прати друго, које има корене у антропологији и односи се на одређени начин живота који изражава извесна значења и вредности не само у уметности и знању, већ и у институцијама и свакодневном понашању. Сведена на индивидуални ниво, култура се може објаснити и као виђење сопственог живота, живота заједнице, збир прећутних смерница у поступању и доживљавању света око нас.

Последњих деценија у друштвеним наукама је појам културе све распрострањенији, а то појачано интересовање је и даље у порасту, што се сматра последицом „културалног преокрета“, који се догодио под утицајем економских, политичких и културних промена насталих у оквиру постиндустријског друштва. Да би се објаснили модернизација савременог друштва, демократизација и све што тај процес производи - војна стратегија у новим измењеним околностима у међународним односима или односима између етничких и других друштвених група на унутрашњем плану држава све чешће се посеже за културом и њеним елементима.

На тај начин је појам културе постао све фреквентније коришћен, истовремено функционишући у разним дискурсима, политичким, економским, националним, глобалистичким, расистичким и сличним. Са својевремено успостављене позиције у којој је посматрана као посебна сфера друштва, представљена високом уметношћу, култура је у међувремену прожела и све друге домене друштва.

2 Френк Џ. Лечнер, Џон Боли, Култура света, Клио, Београд, 2006, стр. 28-29. 
Данашњи свет је оптерећен бројним противречностима, као неминовним последицама сложених промена у другој половини двадесетог века. Суочавајући се са растућим и евидентним проблемима који нарушавају и угрожавају вредности појединца, друштвених група, друштва у целини или међународне заједнице, у фокусу пажње теоретичара и истраживача све више су заступљени култура и безбедност, као главни „актери“ свих сложених односа међу људима, народима или државама.

Догађаји, изазови и нови развојни токови, као што су демократска консолидација у послератном Ираку или рат против тероризма, довели су до потребе да се размишља на иновативан начин када су у питању односи између културе и безбедности. Некада секундарна, култура је сада постала веома важан чинилац у развоју међународних односа, међународне, али и националне безбедности. Заправо, она је одувек била важна и њен утицај се рефлектовао кроз све сфере једног друштва, али је последњих година њено присуство у међународним односима у значајној мери остварено и кроз промене у расподели моћи, у њеним новим изворима и облицима. Наиме, нови видови испољавања моћи у међународним односима јесу не само степен техничкотехнолошког развоја и образовне структуре становништва, већ и привлачност културних добара и ресурса, идеологије, начина размишљања и живота, односно привлачност укупног цивилизацијског обрасца. ${ }^{3}$

С друге стране, концептуализација безбедности такође доживљава далекосежне промене, у чијој се основи укорењује ново мишљење и практиковање безбедности, које би требало да омогући сигурније, праведније и боље уређено друштво. То је у условима нових безбедносних изазова, ризика и претњи ${ }^{4}$

3 Драган Симић: Наука о безбедности - савремени приступи безбедности, Факултет политичких наука, Службени лист, Београд, 2002, стр. 37.

4 Тешко је распознати и описати збуњујући низ проблема с којима се сада суочава човечанство. Својевремено је генерални секретар УН Кофи Анан то сажео у извештају УН Безбеднији свет, из децембра 2004. године: „Сви смо слаби према новим угрожавањима безбедности и старим претњама, које се сада постепено развијају на комплексне и непредвидиве начине... Шест најважнијих група су: економске и социјалне претње, укључујући сиромаштво и неизлечиве заразне болести, конфликти и ривалитет међу 
знатно отежано, али и захтевније у смислу нових приступа и облика супротстављања који се нарочито препознају у превентивним стратегијама, концепцијама и конкретним мерама.

Идеја да култура може дефинисати стратешке исходе, први пут се уочава код класичних теоретичара Тукидида [Thoukydídess], Сун Цу Вуа [Sun Tzu Wu], касније и Клаузевица [Clausewitz]. Рана истраживања су покушала да објасне како „национални карактер“ може утицати, односно довести до различитих начина вођења рата. Наиме, на основу ових претпоставки долазило је до повезивања културе и политике безбедности фокусиране на „национални карактер“ као производ језика, религије, навика, социјализације и интерпретације заједничких историјских искустава. ${ }^{5}$

Одувек се, дакле, веровало да су културно знање и ратовање нераскидиво повезани. Културно знање као средство за побољшање војне снаге наглашавао је и Херодот, који је истицао значај познавања других „противничких“ карактера током Персијских ратова (490-479 г. п.н.е.). Многе војсковође и војници у различитим историјским епохама, напамет су знали стихове Сун Цу Вуа: „Ако знам непријатеља и знам себе, не морам се плашити резултата стотину битака.“ Такође, многи савремени војни теоретичари и војсковође

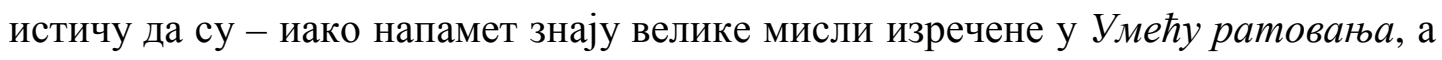
посебно „упознај непријатеља“, као један од првих принципа ратовања - бројне војне операције и донете одлуке значајне за националну безбедност претрпеле неуспех управо због недостатка знања о страним културама и друштвима и непознавање културног контекста у којем се одвија свакодневни живот. ${ }^{6}$

државама, унутардржавно насиље, укључујући грађанске ратове, распад државе и геноциде, нуклеарно, радиолошко, хемијско и биолошко оружје, тероризам и транснационални организовани криминал.“

5 Jeffrey S. Lantis, Derryl Howlett: „Strategic Culture“, in: Strategy in the Contemporary World, Edited by John Baylis, James Wirtz, Colin S. Gray, and Eliot Cohen, Second Edition, Oxford University Press, 2007, p. 84.

6 Тако, на пример, америчко искуство ратовања веома добро илуструје ову тезу, и то на бројним примерима ратова које су водили у XX и почетком XXI века: рат у Вијетнаму, Авганистану или Ираку. Ови различити „мали“ ратови упозорили су политичаре, стратеге и 
Култура је нашла своје место и у другим друштвеним активностима, па су тако политиколози Габријел Алмондо [Gabriel Almondo] и Сидни Верба [Sidney Verba] покренули интересовање за политичку културу, коју су дефинисали као „подскуп“ уверења и вредности друштва које се ослања на политички систем. За њих политичка култура обухвата обавезу да се поштују вредности као што су демократски принципи и институције, идеје везане за морал и употребу силе, права појединаца и заједница, као и предиспозиције ка месту и улози одређене земље у свету.

Социолог Ен Свидлер [Ann Swidler] предложила је комплекснији модел повезивања између културе и понашања државе наглашавањем посредничке улоге онога што она назива културалне „стратегијске акције“. Свидлерова дефинише културу у веома широком смислу и наводи да се она састоји од симболичких преносилаца значења, укључујући уверења, ритуалне праксе, уметничке форме и церемоније, као и неформалне културне навике, а то су нпр. језик, оговарање, приче и свакодневни ритуали. На основу аргумената Макса Вебера [Max Weber] и Талкота Парсонса [Talcott Parsons], она тврди да су стратегије вођене интересом веома важно посредничко стање када је у питању понашање државе. ${ }^{7}$

Половином седме деценије прошлог века Џек Снајдер [Jack Snyder] уводи културу у модерно истраживање безбедности, развијањем теорије стратешке културе ради интерпретирања совјетске нуклеарне доктрине. Он сматра да је

војне лидере на значај културе на тактичком и оперативном нивоу. Разматрања о томе како култура утиче на политичке и стратешке акције, понашање и поступке других постала су витални стратешки задаци. Способност да се разуме и цени улога и утицај културе у политици и стратегији се све више посматра као вештина критичког стратешког размишљања. Културно знање на нивоу политике и стратешког деловања значи способност да се размотре историја, вредности, идеологија, политика, религија и друге културне димензије и процени утицај на њихове потенцијалне политике, пре свега у безбедносној сфери.

7 Jeffrey S. Lantis, Derryl Howlett: „Strategic Culture“, in: Strategy in the Contemporary World, Edited by John Baylis, James Wirtz, Colin S. Gray, and Eliot Cohen, Second Edition, Oxford University Press, 2007, p. 84. 
група општих уверења, ставова и шаблона понашања, уз узимање у обзир нуклеарне стратегије, постигла стање полутрајности, које је смешта на ниво „културалног“ уместо на саму политику. Снајдер је применио стратешкокултурални оквир за интерпретацију развоја нуклеарних доктрина Совјетског Савеза и САД као функцију различитих организационих, историјских и политичких садржаја, као и технолошких ограничења. Он је закључио да је совјетска војска показала преференцију за превентивну, офанзивну употребу силе, а почеци тога би се могли пронаћи у руској историји несигурности и ауторитативној контроли.

Колин Греј [Colin Gray] је такође навео да различити национални стилови, са дубоким коренима у оквиру „појединачног тока историјског искуства“, карактеришу стратешки развој у земљама као што су САД и Совјетски Савез. На основу тога нуклеарна стратегија може бити повезана са историјским политичким оријентацијама. Греј је дефинисао стратешку културу као „режиме размишљања и акција уз узимање у обзир силе која потиче од перцепције националног историјског искуства, од аспирације за одговорно понашање у државном смислу“, па чак и од „грађанске културе и начина живота“. Према томе, стратешка култура „обезбеђује средину у оквиру које се дебатује о стратегији“ и служи као одлучујући независни фактор стратешких политичких шаблона. Као и Снајдер, Греј је сматрао да би стратешка култура могла имати условно трајни утицај на безбедносну политику. ${ }^{8}$

Како култура обликује националну безбедност, најбоље се види кроз понашање државе у међународним односима и, у складу са тим, остваривањем такве позиције са које може да значајно утиче на друге државе на међународној сцени или да трпи њихове утицаје. Културу је и у том контексту тешко дефинисати, али се теоретичари слажу да је то, у сваком случају, битан концепт у међународним односима. Када се посматра и анализира ова сфера деловања културе, запажају се три подручја где она често проналази употребу при разматрању међународних односа, а то су, као што смо већ навели, повезана поља политичке, стратешке, али и организационе културе.

8 Исто. 
Да би се анализирала структура односа културе и безбедности, оба појма се морају сместити у раван која ће дати стабилност и солидну утемељеност теоријском промишљању. То може, дакле, бити ниво националне безбедности, где се још укрштају и појмови као што су: национална култура, национални и/или културни идентитет и национални интереси. Још од времена настанка савремених националних држава, постало је јасно да културе могу бити изграђене конструкцијама и свесним политикама, али да такође могу бити инструмент помоћу којег можемо обликовати људе, њихово мишљење, предрасуде, емоције, обрасце понашања, политичке преференције.

Познато је да се национална безбедност односи на делатност државе којом она, у складу са својим друштвеним могућностима у садашњости и ресурсима које гради за будућност, штити властити идентитет, опстанак и интересе. При том су друштвене могућности у свом најширем схватању условљене и културним обележјима, као што су традиција, вредности, веровања, институције, али и начин живота. Када говори о безбедности, Љ. Стајић наглашава управо ту димензију друштва, јер да бисмо били безбедни, „није довољно само одсуство неког или нечег што нас угрожава, већ се мора живети у друштву које обилује правдом, моралом и културом, друштву које стално унапређује своје вредности“. 9

Теоретичар Каценстејн [Peter J. Katzenstein] је истакао социолошке институционалне перспективе политике националне безбедности и при том размотрио две детерминанте безбедносне политике - културалноинституционални контекст и замишљен или изграђен идентитет држава, влада и других актера. ${ }^{10}$ Наиме, он такође наводи најмање три дејства која културолошко окружење може да има на идентитет државе, а тако и на

\footnotetext{
9 Љубомир Стајић, „Неке недоумице око схватања безбедности у ХХІ веку“, у: Ризик, моћ, заштита - Увођење у науке безбедности, приредио Владимир Н. Цветковић, Службени гласник и Факултет безбедности, Београд, 2010, стр. 342.

${ }^{10}$ Jepperson, R. L., Wendt, A., Katzenstein, P. J. (1996), „Norms, Identity and Culture in National Security“, y: Katzenstein, P. J. (yp.), The Culture of National Security: Norms and Identity in World Politics, Columbia University Press, New York, pp. 33-75.
} 
интересе и политику националне безбедности. Прво, може да утиче на изгледе да држава, пре свега, уопште преживи као ентитет.

Друго, окружење може да промени систем облика државности током времена. Данас, у супротности са касним деветнаестим веком, било би готово непојмљиво да држава олако изгласа да постане колонија. Сходно томе, све до деветнаестог века оружани сукоб је виђен као морална вежба државне снаге; док данас државе, и даље устројене да воде ратове, мењајући међународне норме, нису имуне на унутрашње факторе који „слабе“ агресивне импулсе многих држава. То је приметно нарочито на Западу, стварајући такво расположење да се рат сагле̄да као нужно зло.

На крају, као треће дејство, културолошко окружење може да проузрокује промене обележја државности у оквиру датог међународног система. Познат је пример како су се, као последица Другог светског рата, одвијале промене политике идентитета у Немачкој и Јапану, које су оформиле нове идентитете трговачких држава.

Пратећи ову мисао, а за разлику од већ поменутих димензија политичке, стратешке и организационе културе, сматрамо да ваља увести нову употребу појма културе у концепту безбедносне културе, који треба да нам омогући да утврдимо нека понашања у безбедности, у систему као целини, његовим појединим деловима унутар посебних групација (супкултура), као и на кључним тачкама безбедносне иницијативе и одлучивања, пре свега на нивоу државе, али и неког другог ентитета. Култура и правила понашања у безбедности мењају се, развијају и усложњавају у складу са промењеном улогом државе и са променом безбедносног амбијента унутар или изван државне територије, укључујући и промену карактера безбедносних претњи и ризика.

Те промене иницирају и појаву нових актера и измењену улогу старих актера ${ }^{11}$ у безбедности чији се безбедносни интереси усклађују и са факторима културе.

${ }^{11}$ Стварање и развој нових актера (подразумева се, и наддржавних и унутардржавних) како на међународној, тако и на унутрашњој сцени - није укинуло значај државе, већ је утицало само на њену улогу и садржај активности, а развијају се и нови односи и релације које 
Културе које они поседују и испољавају, интерно и једни према другима, могу да утичу на начин на који дефинишу и остварују своје циљеве. Чак и у стабилним околностима, култура одређује и обезбеђује читав репертоар ставова и одговора базираних на веровањима и навикама који преовладавају у држави или који су успостављени међу државама у њиховим узајамним односима. До које границе могу да се користе норме и идеје у објашњавању одређених исхода, остаје отворено за будућа размишљања и укрштања различитих ставова о том питању, али ћемо кроз бројне илустрације у раду приказати сложеност тих могућности које се пружају аналитичарима и истраживачима.

Као што ће у раду бити објашњено, културолошке теорије већ дуго располажу истакнутим местом у пољу међународне безбедности, а нови културалисти у безбедносним студијама верују да је реализам, као доминантни истраживачки правац у међународним односима након Другог светског рата, прецењен и да културолошке теорије дају много боље објашњење како свет „ради“.12 Додаћемо: и за то како се иначе различити (и једноставни и комплексни) процеси и активности у једном друштву одвијају, управо под утицајем или бар у контексту културе и културних појава и феномена.

У заједничким настојањима да овај свет учине извеснијим и сигурнијим за све људе, народе и државе, култура и безбедност граде сложен однос, који понекад може да произведе и негативне консеквенције. Намера аутора овог рада јесте да се акцент стави на развој, добробит и извесност, као позитивне исходе њиховог међусобног деловања, а који се могу пронаћи или уочити у концепту чије промишљање почиње, а који је означен као безбедносна култура.

Потреба и интерес савременог (цивилног) друштва за безбедношћу, која је условљена и омогућена социјалним променама и трендовима у јачању демократских институција, може се остварити стабилним утемељењем и

остварује са тим актерима, без обзира на то што понекад делује да је ово науштрб њеног суверенитета.

12 Michael C. Desh, „Culture Clash - Assessing the Importance of Ideas in Security Studies“, International Security, Vol. 1, 1998, pp. 141-170. 
развијањем безбедносне културе. Дистинкција између потребе и интереса за безбедношћу и потребе за културом односи се углавном на начин на који се долази до задовољења тих потреба, који је најчешће одређен утицајима из друштвеног окружења. Култура и цивилизација одређују начине задовољавања потреба које су важне за достојанствен и квалитетан живот. Безбедносна култура као концепт може се, дакле, сместити у оквир дисциплине која безбедносне појаве живота настоји да спозна у њиховом културном значењу.

Управо из потребе да се сагледају могућности најопштијег и најпрегледнијег представљања концепта безбедносне културе, узимајући у обзир све димензије и различите ентитете на које се он може применити, настала је идеја да се напише овај рад. Неки други савремени теоријски приступи безбедности, који се баве појединцима и маргинализованим друштвеним групама, сазнања до којих долазе веома тешко користе у анализи и међународне и глобалне безбедности. Када је у питању безбедносна култура, ствари стоје другачије, јер се само на основу прелиминарне анализе литературе може рећи да овај концепт оправдано сврставамо у групу „теорија усмерених на решавање проблема“, а што ће касније током рада бити потврђено и одговарајућом аргументацијом. Што је најважније, врло лако се може применити од појединачног до глобалног нивоа.

Шире посматрано, безбедносна култура се може представити као веома важна област регулисања друштвених односа и друштвених активности, али је, и ради даљег развоја друштва у целини, неопходно испитати све аспекте изградње и развоја концепта безбедносне културе. Он није довољно истражен и разрађен у нашем друштву, па самим тим постоји потреба свестраног, дугорочнијег и студиознијег приступа. При том се мора уважити и чињеница да је тај концепт релативно нов, али у неким својим димензијама у доброј мери и проучен, пре свега код западних истраживача и теоретичара. Према доступној литератури, уочено је да је присутан и да се развија тек нешто више од две деценије. ${ }^{13}$

13 Појам „безбедносна култура“ први пут је поменут у Завршном извештају Међународне агенције за атомску енергију (IAEA, 1986) о нуклеарној катастрофи у Чернобиљу, упоредо са још једним сродним појмом и концептом - сигурносна култура [safety culture], који ce сматра старијим и развијенијим, али ужим и са мањим апликативним могућностима. Уочено 
Наиме, почетна замисао о безбедносној култури у западним друштвима везује се за широк спектар организација, укључујући и оне које обухватају јавну безбедност, безбедност јавног транспорта, као и нуклеарну индустрију. Ипак, примећено је да у литератури недостаје управо излагање о томе како се конституисао концепт и који су то битни елементи и категорије из поља културе и поља безбедности учествовали у томе и у каквим релацијама.

Због тога се као основни циљ овог рада и може дефинисати сагле́дање претпоставки разумевања појма безбедносна култура и претпоставки његовог развоја као теоријског концепта. Уколико појам безбедносне културе што прецизније дефинишемо и концептуално профилишемо, самим тим отворићемо могућност да и теоријски буде плодан, тј. у систематском погледу значајан. Између осталог, то подразумева сагле́дање могућности развоја и примене концепта безбедносне културе као инструмента научне анализе који треба да послужи и као средство за откривање општих веза и односа између појмова.

Откривање, креирање и обликовање теоријског концепта безбедносне културе и његово развијање реализоваће се у условима примене више теоријских перспектива (које припадају и домену културе и безбедности) и истраживањем могућности његове практичне примене. Да би се то остварило, неопходни су дубља анализа и суочавање релација на којима се граде односи између његових конститутивних појмова и развијање, тј. представљање потенцијалних методологија за истраживање и имплементирање безбедносне културе у оквире безбедносне политике државе, организације или неког другог ентитета. Наиме, комплексност истраживаног феномена може довести до недореченог и непрецизног формулисања и разматрања фактора који су изузетно важни за безбедност. Због тога је посебна пажња усмерена ка појмовно-теоријским разјашњењима основних категорија, као што су: култура, национална култура, вредности, идентитет, традиција, безбедност, национална безбедност, безбедносна култура и други.

је да се, поред области нуклеарне безбедности, када је у питању његова практична димензија, концепт безбедносне културе највише везује за област заштите информација (у великим корпорацијама), процене ризика, у сфери глобалног управљања итд. 
Као пратећи циљ намеће се, дакле, и могућност да се знања о безбедносној култури систематизују и ставе у комплетнији и уређенији методолошки оквир који ће уједно развијати прецизније методолошке инструменте за ефикаснији развој и имплементацију безбедносне културе.

На почетку, треба истаћи и потенцијал концепта безбедносне културе да обухвати више „проблемских ситуација“, тако да ћемо се у раду бавити његовом природом, садржајем, теоријским моделима, начинима на основу којих се може развијати. Наравно, све то је неопходно како бисмо дошли до резултата који ће нам представити безбедносну културу као незаобилазан чинилац безбедносне политике унутар једне државе и на међународном плану, који значајно утиче да се безбедност унапреди и развије.

Безбедносна култура може представљати прихватљив оквир или образац за безбедносну политику која ће бити смислена за теоретичаре и корисна за практичаре безбедности. Смисао овог концепта се огледа управо у томе да постави, али и објасни темеље безбедносне политике и да дефинише, а затим и развије средства која ће омогућити развој и просперитет државе, а на појединачном нивоу добробит, сигурност и квалитет живота. Безбедносна култура се такође може сагледати у контексту превенције друштвених конфликата, системских одговора на ризике и као конститутивни део нових безбедносних инфраструктура.

Шири приступ проблему истраживања отворио је многобројна питања и дилеме, за које смо се трудили да пронађемо адекватна решења и одговоре. Нека од тих теоријских питања и претпоставки, које могу имати и функцију хеуристичких смерница, гласе:

- Постоје ограничења материјалистичког поимања моћи у разумевању структуре и динамике савремених безбедносних односа.

- Критички и конструктивистички приступ безбедности, укључивањем интерсубјективних подручја културе и идентитета у безбедносну анализу, дају боља и свеобухватнија објашњења тога како свет „ради“. 
- Култура и идентитет се могу представити као средиште развијања интереса безбедности и безбедносне анализе.

- Национална безбедност је условљена националном културом и идентитетом.

- Савремени приступ концепту безбедносне културе истиче његова обележја која имају синтетичку, трансферну и развојну димензију.

- Претпоставке развоја безбедносне културе, као теоријског концепта и кроз његову практичну примену, крећу се у правцу аналитичких, развојних и инфраструктурних могућности.

И поред тога што предмет овог рада припада домену наука безбедности, исцрпно су коришћена теоријска достигнућа и резултати промишљања са подручја социологије, политикологије, психологије, антропологије и других друштвенонаучних дисциплина. Постављени задатак је свакако задовољење људских потреба у разумевању сопственог света, дакле и друштва, које ниједна од наука појединачно не може испунити. Интердисциплинарна трагања увек доносе више сазнајне плодности, нове теоријске перспективе, а изласком изван оквира једне дисциплине ослобађамо се институционалних рутина, које, иначе, често знају да инвентивност жртвују методолошком конформизму. 


\section{1 ПОСТАВКЕ ИСТРАЖИВАЫА}

\section{1 Предмет истраживања}

Имајући у виду глобално идентификован значај културе за безбедност и извесне недостатке у досадашњој тематизацији, као и начин представљања овог односа како у страним, а посебно у домаћим научним студијама, предмет овог рада је анализа претпоставки развоја концепта безбедносна култура. Да би се ова анализа развила на сврсисходан начин, сви токови аргументације, дискусије и разјашњења градили су се на темељу перспектива више теоријских дисциплина, при чему се највише мисли на културолошке теорије, теорије у оквиру наука безбедности, као и социолошких, политиколошких и других сродних домена.

Предмет истраживања је обухватио идентификовање и компарацију теоријских исходишта у којима се проналазе могуће сличности, али и размимоилажења са концептом безбедносне културе који смо развијали, при чему је било кључно утврдити садржај и суштину феномена „безбедносна култура“, његова обележја која имају синтетичка, трансферна и развојна својства. Кроз призму културе, националне културе, националног идентитета, концепта безбедности и националне безбедности одсликавају се својства безбедносне културе, конкретизована и моделована као специфична безбедносна инфраструктура.

Идентификована трансферна и развојна својства безбедносне културе имају своју практичну димензију, која се може утврдити кроз одговарајуће индикаторе, којима се процењују имплементациони капацитети безбедносне културе у оквиру неког ентитета. Предмет истраживања обухватио је и компарацију више приступа, дакле социолошког, психолошког, аналитичког, хуманолошког, али и организационог приступа на путу дефинисања безбедносне културе, као својеврсне, нове безбедносне инфраструктуре. 
Да бисмо утврдили шта обухвата појам безбедносне културе и у којем се правцу могу развијати теоријске анализе и тумачења, неопходно је да прво представимо основне теоријске поставке којима ћемо усмерити даљи ток рада. За почетак би било добро да наведемо његове мање апстрактне саставне делове, тј. да опишемо поједине равни у којима се испољава оно што помоћу појма намеравамо да означимо. Полазимо, дакле, од његових градивних елемената, а пре свега од појма културе.

\subsection{1 Култура}

Појам културе је једна од темељних категорија у животу човека, веома је комплексан и тешко ухватљив, тако да често измиче прецизном и недвосмисленом дефинисању. За потребе овог рада приказана су нека сасвим општа одређења, али и она која се одликују извесном специфичношћу. Најопштије и у науци често прихваћено, али и критиковано антрополошко схватање културе дефинише је као начин живота, или као друштвено дефинисан начин живота.

За ову дефиницију неки аутори сматрају да је превише општа и да се не може третирати као дефиниција у правом смислу речи. Такође, одређивање културе као суме целокупних достигнућа која је човек стекао као члан друштва ограничава појам културе и не открива њен пуни садржај и богатство. Као прихватљивим приступима у дефинисању културе даћемо првенство онима који полазе од фундаменталних функција културе, које служе задовољавању човекових потреба, али и постављању нормативних циљева, тј. одређивању стандарда толерантне и пожељне егзистенције.

Да бисмо разумели шта све обухватају и бројна друга тумачења, потребно је поћи од фундаменталне поделе човеку знаног универзума на свет природе (то је све што постоји пре човека и независно од његове воље) и свет културе (који укључује све што је човек створио и што може да замисли). ${ }^{14}$ У многим

14 Ранко Бугарски, Језик и култура, Библиотека XX век, Београд, 2005, стр. 14. 
разматрањима култура се представља као чинилац који је помогао човеку да из природног пређе у друштвено стање. Традиционална схватања истичу како је однос биолошког и културног развоја човека такав да је биолошки претходио културном, што значи да се човеково физичко биће развијало кроз уобичајене механизме генетских промена и природне селекције, све док његов анатомски склоп није добио мање-више садашњи облик. Тек тада је почео његов културни развој. ${ }^{15}$

Савремена размишљања указују на чињеницу да је еволуција homo sapiens-a човека каквог знамо - из његове непосредне пресапијентске основе започела пре четири милиона година појавом првобитног човеколиког мајмуна аустралопитека и достигла врхунац појавом самог sapiens-а пре само једне, две или три стотине хиљада година. Пошто су неки аустралопитеци имали елементарне облике културне активности (једноставно прављење оруђа, лов итд.), дошло је до преклапања између почетка културе и појаве човека каквог данас познајемо.

Тај период је, према неким проценама, могао да траје знатно више од милион година. Завршне фазе човекове филогенетске историје одвијале су се у истом великом геолошком раздобљу - леденом добу - као и почетне фазе његове културне историје. Из тога је произашла и констатација да људи имају рођендане, али човек нема. Наиме, према савременим размишљањима, култура је преузела главну и усмеравајућу улогу у еволуцији човека. Пошто се култура постепено акумулирала и развијала, селективну предност су добијали појединци који су били најспособнији да је искористе (вешт ловац, упоран сакупљач, спретан произвођач алатки и оруђа).

Као што је теоретичар Клифорд Герц [Clifford Geertz] такође навео у својим радовима, „човек је непотпуна или недовршена животиња која се употпуњује

15 Према истом схватању на одређеном ступњу његове филогенетске историје нека врста маргиналне генетске промене учинила га је способним да ствара и носи културу, и од тада је облик његовог одговора адаптације на притиске околине готово искључиво културни, а не генетски. Видети шире у: Клифорд Герц, Тумачење култура 1, Библиотека XX век, Београд, 1998. 
односно довршава кроз културу“, што значи да можемо рећи како без човека нема културе, али исто тако и још важније - без културе нема човека. И даље остаје недефинисана граница између онога што је урођено контролисано и онога што је културно контролисано у људском понашању - понекад је нејасна и нераспознатљива или несазнатљива.

За развијање и разумевање концепта безбедносне културе веома је важно нагласити димензију културе која обухвата скуп контролних механизама планова, упутстава, правила и поука за управљање понашањем. Човек је управо животиња која зависи од таквих екстрагенетских, спољашњих механизама и таквих културних програма који уређују његово понашање. Овде се култура приближава синтетичком смислу појма ,управљања“ [management] - што значи „постићи циљ упркос тешкоћама“ - где је, као и у основи управљања, важно урадити ствари на начин на који људи сами то не би обавили без надзора. ${ }^{16}$ Оваквим описом појма „управљати“ и прављењем аналогије са појмом културе указује се и на ограничавање слободе објекта управљања, које има свој смисао и оправданост у случају да доноси више безбедности и сигурности.

Изучавање културе са овог становишта полази и од претпоставке да је људска мисао у основи и социјална и јавна, при чему то мишљење не чини само оно што се дешава у глави, већ подразумева и размену значењских симбола (речи, гестови, музички звукови итсл). Са становишта било којег појединца, таквих симбола има много и они помажу човеку да објасни догађаје кроз које пролази, али и да се оријентише у непрекидном животном току, који доноси и бројна искушења. Не треба заборавити да се у људској пракси сједињавају елементи значења, узора и вредности са циљевима које човек тежи да оствари, па је и појам културе знатно садржајнији и богатији него ако се посматра само у смислу симболичких система, али је он веома значајан и мора се уважити у свим расправама о култури. Потчињавајући се управљању симболички посредованих програма за произвођење артефаката, организовање друштвеног живота или изражавање осећања, човек је готово ненамерно одредио највише

\footnotetext{
16 Зигмунт Бауман, Флуидни живот, Mediterran Publishing, Нови Сад, 2009, стр. 68.
} 
стадијуме сопствене биолошке судбине и тако готово нехотично створио самог себе.

Култура се и у науци појавила као термин који има значење управљања или уређења (обликовања) људске мисли и понашања. Тако је ушла и у речничке одреднице као сврсисходна активност што има циљ да култивише људска бића, која су иначе подложна утицајима и са великим потребама да се поправе или побољшају. Отуд је и значење култивисања употребљено са истим крајњим циљем - побољшања (првобитно усева, кроз пажљиву бригу ратара од сетве до жетве, а затим примењена на човека, од малог детета до одраслог појединца путем образовања и васпитања).

У сваком случају, може се прихватити становиште које културу одређује као процес(е) обликовања, контроле и управљања људским мишљењем и понашањем (као појединца или дела групе), како би на подеснији начин решавао своје егзистенцијалне проблеме, задовољавао фундаменталне потребе и интересе, развијао нове аспекте живота и који као крајњи резултат дају хуманијег човека и хуманије друштво.

Култура се може условно поделити на две широке области, материјалну и духовну, а код овог приступа се у разматрање обично уводи и појам цивилизације. Њиме се понекад обухватају оба ова подручја културе, а покаткад једно од њих, што је најчешће ствар приступа и теоријске оријентације. Шире схватање културе свакако истиче да она обухвата како материјална тако и духовна добра извесне заједнице (етничке, националне, професионалне). Због тога је, према неким ауторима, и потребно културу посматрати у три релевантна значења: антрополошком (које се тиче начина живота), цивилизацијском (које се усредсређује на физички и умни рад те на стваралаштво као његов производ) и бихејвиоралном (које обраћа пажњу на обрасце понашања).

Све ове компоненте обухвата или на неки начин подразумева и језгровито одређење културе које је дао УНЕСКО, организација несумњиво меродавна у овој области, а које гласи: „Културу чине вредности, веровања, језищи, науке и 
уметности, традиџије, институције и начин живота којима се једна личност или група изражавају, остварују и развијају.“17

Значења културе можемо сагледати и кроз призму појединих националних тумачења. Француски смисао упућује на идеју стварања дела. Он претпоставља могућност одређења онога што се у датом тренутку сматра наслеђем, вештином, стварањем и знањем, јер претпоставља да се ова одређења развијају у времену. Немачко значење је блиско идеји цивилизације и спаја вредности, представе, симболе и наслеђе, онако како их у датом историјском тренутку дели једна заједница. Англосаксонско значење је више антрополошко и у обзир узима начин живота, стилове, свакодневна знања, представе и митове.

На основу свега реченог и имајући у виду идеју која нас је покренула, морао би се прихватити управо специфичан и посебан карактер сваког облика културе. Све више се одбацује схватање да је култура заједничка за читаво човечанство, да зависи од достигнутог степена развоја, како су сматрали антрополози присталице теорије еволуције, а прихвата се постојање мноштва култура, од којих је свака легитимни израз људског „духа“ и исход посебног историјског процеса. $^{18}$ Подразумева се не само прихватање мноштва култура, већ и мноштва погледа и размишљања на тему културе.

Три суштинска елемента обележавају поље у оквиру којег се може разматрати култура да би се ближе одредили не само утемељени процеси што је стварају, већ и токови који ремете њен поредак и у извесном смислу се свесно намећу како би се започела тзв. модернизација и достигло толико жељено приближавање савременом друштву. Та три елемента су: промена, традиција и идентитет. Први је процес, други је систем вредности, а трећи историјско достигнуће. Свака расправа о култури развија се као покушај да се та три елемента повежу указивањем на њихове разлике и дисконтинуитет.

17 (UNESCOMexicoCityMONDIACULTWorldConference 1982), видети: www.unesco.org.

18 Термин „култура“ је са̂м по себи проблематичан, јер је и даље снажно повезан са архаичним ставовима о „примитивним“ групама, поготово у смислу супериорности повезане са колонијализмом. 
У том смислу традиција се може схватити као основа на коју неизоставно морају да се надовежу иновативни процеси, идеје и импулси промене. Развој, промене и модернизација нужно зависе од система вредности, правила, заједничких знања ентитета обухваћених процесом иновације. Сви аутори који су се бавили културом наводе у својим дефиницијама и вредности као темељну категорију. Вредности можемо разумети као трајан изразито позитиван однос према одређеним објектима које оцењујемо као важне и за чије остварење постоји лично ангажовање. Једна од основних карактеристика вредности јесте да утичу на понашање и на формирање ставова. Уколико се тежи стварању снажне културе (снажне у свим димензијама, подразумева се и у безбедносној), неопходно је да шира заједница буде упозната са темељним вредностима и да се оне негују, презентују и промовишу у свакој прилици, али исто тако и да се чувају и штите, када се за тим укаже потреба.

Култура је та која шири простор вредности, али да би то постигла, неопходно је да прихвати изазов нових потреба и нових вредности, стваралачко тражење, ризик који стреми дубини, дух динамичности и разноврсности, стваралаштво као људску „аутономију“ и „испуњење“. Култура је важна не само у деловању на вредности, већ и на погледе на свет и структуру међуљудских односа. Начин на који култура може утицати на ставове и социјалне односе верификован је у широком распону области, као што су индивидуализам/колективизам, родност, дистанца моћи и културна комплексност. И коначно, културне варијабле могу бити представљене кроз утицај широког низа социјалних, политичких, безбедносних и пословних понашања.

Од краја Хладног рата концепт културе остварује нов утицај кроз готово драматичан повратак међународној позорници, при чему се обистињавају предвиђања неких изучавалаца да ће се та присутност још више осетити у новом миленијуму, као потенцијално оружје новог моћног судара, способна да замени војну принуду као политичко средство. ${ }^{19}$

19 За јасно схватање културе кроз новије домете литературе у области међународних односа, безбедносних студија и међународне економије видети: Mazarr J. Michael, „Culture and International Relations: A Review Essay“, Washington Quarterly 19:2, Spring 1996; William 
Симболи културног идентитета су све израженији у периоду након Хладног рата, када се и развија теза да су култура и културни идентитет најзначајнији за човека и за већину људи. То је и раздобље када најважније разлике међу људима нису идеолошке, политичке или економске, већ културне. ${ }^{20}$ Културне разлике се пре свега огледају у посебном систему вредности, начину на који су регулисани друштвени односи, обичајима, општем погледу на свет и живот. Основне разлике у вођењу политике, развоју економије или промишљању безбедности и понашању у сфери безбедности јасно се огледају и дубоко су укорењене у различитим културама.

На који начин различите културе стварају и негују посебне обрасце политичког и економског развоја, тако и обликују специфична размишљања, ставове и понашања у сфери безбедности, што представља довољан услов за развијање новог теоријског концепта у виду безбедносне културе. Култура на тај начин крчи пут не само савршенству ${ }^{21}$ већ и сигурности.

Култура са атрибутом безбедности фокусира своје отелотворење на сегмент који обухвата она знања, ставове, правила и понашање који су усвојени,

Zimmerman, Harold K. Jacobson, eds.: Behavior, Culture, and Conflict in World Politics, Ann Arbor: University of Michigan Press, 1993; Yosef Y. Lapid, Kratochwil, eds., Return of Culture and Identity to IR Theory, Boulder, Colo.: Lynne Rienner, 1996.

20 Разноликост је једна од кључних преокупација социолошких, политиколошких, културолошких и многих других теоретичара друштвене оријентације, а њено очување је идеља водиља Европске уније, Савета Европе и других међународних институција и њихових докумената. Када је у питању разноликост култура, као што је већ примећено, постоје неке опречне поделе на примитивне и развијене, и с тим у вези постоје многе укорењене заблуде и предрасуде. Видети: Семјуел Хантингтон, Сукоб циивилизаиија, ЦИД, Подгорица, Романов, Бања Лука, 2000, стр. 21.

21 У том смислу култура је, поред већ реченог, све више и трагање за потпуним савршенством кроз сазнање о свему што нас се тиче и најбоље што је мишљено и речено у свету, а која кроз то сазнавање уноси струју свеже и слободне мисли у наше уврежене појмове и навике. Она тежи томе да најбоље што је мишљено и знано буде заступљено свуда у свету, да сви људи живе у атмосфери „свежине“ и „светлости“ у којој могу да користе све идеје, као што их она сама користи, слободно - неговани, а не оковани њима. Но, и то се многима, за сада, чини недостижним. 
прихваћени и који се репрезентују и кроз активности појединца, групе, заједнице и кроз деловање институција, а чији је крајњи циљ да се заштити, сачува и унапреди безбедност и сигурност појединца, односно вредности једног друштва, државе или међународне заједнице у целини. Заправо, у овом раду културу ћемо третирати као онај друштвени чинилац који обликује развој друштвених односа, тако да доприноси развоју (интереса) безбедности појединца, друштвене групе, друштва у целини, а пре свега националне безбедности.

\subsection{2 Национална култура}

Појам националне културе је у литератури прилично неухватљив и често дефинисан нејасно, посебно када се очекује да се утврде границе овог појма и прецизно протумаче структурни елементи, а најчешће нација и „национално“ (где се укрштају најмање два гледишта и/или теоријска исходишта о пореклу нације као етничке или грађанске политичке заједнице).

За сада ћемо прихватити становиште по којем се национална култура може дефинисати као скуп претпоставки, веровања и вредности које деле припадници једне националне заједнице и који битно одређују њихово разумевање света, као и понашање у њему. ${ }^{22}$ Наведене претпоставке, вредности и норме углавном су подсвесног карактера и одређују замисао људске природе, однос према природи, као и односе између људи.

Национална култура је такође начин на који се рефлектује однос културе уопште и националног идентитета. По обиму појма национална култура подразумева свеукупно културално стваралаштво (производњу) које се може препознати као национално. С друге стране, једно квалитативно одређење националне културе може пре свега да подразумева ону врсту културалног деловања које директно утиче на развој националне свести.

22 Н. Јанићијевић, „Глобализација и националне културе земаља у транзицији: конвергенција или дивергенција?“, Пословна политика, год. 31, бр. 7-8, 2002. 
Уважавајући могућу тензију између појмова културе уопште и националне културе, треба истаћи да се било какво стваралаштво које називамо културним сматра отвореним за културну комуникацију најширих размера, али истовремено, уколико је у питању култура, у њој се распознаје оригиналност у форми и садржају као нешто што исказује дух људи и народа међу другим људима и другим народима. У том смислу национална култура представља оквир стваралаштва и деловања који се по обиму и садржају појма не може нивелисати на општу културу. На основу таквог разумевања националне културе може се говорити о њеном утемељењу у одређеним цивилизацијским парадигмама, њеној трајности на основу специфичних културних образаца и актуелности у погледу особености искустава и начина живота једног одређеног народа.

Поједини аутори су (оправдано) указивали на терминолошки проблем при поистовећивању културе и националне културе, помињући друштва (националне државе) која су културно хетерогена. ${ }^{23}$ Често се наводи пример САД и различитих етничких (културних) група - Афроамериканаца, Азијата, Хиспанаца, уз, наравно, преовладавајуће бело становништво (које је такође етнички хетерогено). Због тога неки истраживачи користе термин „социјетална култура““, чиме претходне напомене губе на значају. У теорији и истраживању је ипак појам националне културе постао много раширенији и као такав ће се користити и у овом раду.

\subsection{3 Идентитет}

Идентитет најчешће подразумева скуп и континуитет суштинских својстава којима се нека људска група или јединка дефинишу наспрам других, обезбеђујући тако своју „самоистоветност“. То је, дакле, осећање припадности датом колективу, односно свест о сопственој личности. При томе је идентитет увек сложен од низа компоненти, јер се социјални простор конституише укрштањем и преклапањем различитих друштвених група, сачињених од исто

${ }^{23}$ Исто. 
тако вишестрано оријентисаних појединаца. ${ }^{24}$ Ове компоненте могу се легитимно посматрати и као различите врсте идентитета, па тако имамо право да говоримо о етничком, националном, културном, конфесионалном, социјалном, регионалном и другим врстама или подврстама идентитета - од полног и узрасног до професионалног и политичког.

Постоји, дакле, више аспеката идентитета, али је чињеница да се готово сви теоретичари слажу да идентитет постоји у односу на другог - идеја која је често обухваћена појмом различитости. Наиме, идентитет је друштвена категорија која не изражава само значење што га било који од актера неког односа приписује себи, већ се самодефинисања пре односе на дефиниције које сама индивидуа даје другима, али и други њој. Свака расправа о идентитету као односу указује на то да је он до неке мере остварен према разликама. Вилијем Коноли [William E. Connolly] истиче да је идентитет, био он лични, државни, или неке друштвене групе, увек ,заснован у односу на низ разлика које су постале друштвено признате. Ове разлике су од суштинског значаја за његово постојање. Када оне не би коегзистирале као разлике, идентитет не би постојао као јасан и солидан.“25

Неки научници оспоравају идеју да идентитет зависи од разлике, па тако и теоретичар Оле Вивер [Ole Waever] указује на савремену Европу, која је погодан пример за покретање неких питања у вези са овом тврдњом. ${ }^{26}$

24 Стварно, индивидуе поседују читав низ идентитета - концентричних кругова, а сваки, ма шта да је, сваки репрезентује различите сфере. Први круг би могао бити јединствене карактеристике личности, други најближа породица, трећи - шира фамилија, а затим се кроз запослење, политичку припадност, националност и религију добија још даљи спектар кругова. Идентитет се, међутим, односи на неспецифичне физичке атрибуте, али са јединственом релацијом према окружењу у којем он живи и у сваком другом погледу. То је зато што научници те́же да посматрају идентитет као „relational“ (релациони, такав који се обликује тек у односу на нешто): то постаје са утицајем различитих релација индивидуа и група једних са другима, са околном средином и са природним окружењем.

${ }^{25}$ Connolly, William E., Identity/difference: democratic negotiations of political paradox, Cornell University Press, 1991.

${ }^{26}$ Уместо да прави конструкције како су они други опасни, Европа је након Хладног рата била окосница привлачења за своје растављене делове. Европски дијалог је установио грађане 
Идентитет није дефинисан само у интеракцији са другом опасном страном, јер увођењем дијалога добијамо значајно средство за редефинисање идентитета, који су иначе били конституисани према потпуној и коренитој разлици.

Идентитет припада пољу праксе у оквиру које се могу установити објективни циљеви, а тиме и интереси. Док једна група теоретичара види интересе као материјалне и објективне феномене, друга група те́жи да докаже како интерес проистиче из идентитета, па самим тим не представља материјално својство. Сложићемо се да постојање односа између идентитета и интереса ниједном од њих не гарантује поседовање апсолутне стабилности и оба се могу трансформисати кроз интеракцију и међусобну комуникацију. Међутим, идентитет и интереси су неодвојиви и њима се не треба бавити као узрочнопоследичним односом у једном или другом смеру. Тако ћемо их и третирати у раду.

У том односу веома је важна и култура, јер веровања и идеје које људи заступају и размењују јесу иницијатори циљева које одређени актери настоје да постигну. Процеси који се користе у комуницирању ових уверења помажу у објашњавању тога како се идентитети формирају и одржавају, а ти исти идентитети се, заузврат, ослањају на интересе којима актери стреме. Вероватноћа сарадње или конфликта зависи од тога шта актери мисле о себи и о онима (другима) са којима су у контакту.

У литератури се често напомиње да је национални идентитет једно од најважнијих, али и најпротивречнијих испољавања идентитета. У великој мери национални идентитет условљава развој и испољавања осталих облика идентитета. За разлику од етничког идентитета, као неке врсте социокултурног „гена“ који има снагу готово органске везе, грађански национални идентитет је културно и политичко повезивање чланова које уједињава чланство у датој политичкој заједници као целини на основу прихваћених друштвених вредности и симбола, али на основу могућег избора, обезбеђујући интеграцију индивидуа и друштвених група у једну супериорну заједницу.

једне целовите и слободне Европе која није конституисана против неког вечног непријатеља, чак ни према земљама Источне Европе. 
Да бисмо на најбољи могући начин разумели могућности развоја интереса безбедности који одређени идентитет производи, идеално би било разумети тај интерес и као природно стање у смислу етничког идентитета (етнос) и друштвено стање (са аспекта политичке заједнице), што би као крајњи резултат дало својеврсну рефлексију егзистенцијалне добробити народа и грађанства. ${ }^{27}$ У сваком случају, идентитет је важан, јер представља значајан (не и једини) критеријум за остваривање интереса безбедности, пошто само свест о томе ко треба да буде безбедан даје смисао настојању да се тај интерес оствари.

Улога културе у заснивању идентитета врло је велика и она представља основно цивилизацијско језгро у стварању не само националног идентитета. Пошто је идентитет везан за изградњу система вредности у једном друштву, ако се у идентитет не угради одређени културни образац, онда он постаје празан појам, без суштинског смисла. Култура и стабилан систем вредности тако представљају основне елементе у стварању идентитета.

Постоје модерна питања културе која су пројектована у проблеме идентитета. Многе културне студије и социјалне теорије истражују питање културног идентитета. Културни идентитет се може представити као осећај да постоји континуитет међу генерацијама једне популационе јединице, да постоје заједничка сећања о ранијим догађајима и заједничке представе о колективној судбини. Дакле, то је и свест о припадности групи која историјски настаје и развија се у односима са другим друштвеним групама, али и скуп културних карактеристика по којима се једна група разликује и диференцира од друге. ${ }^{28}$

Сама дефиниција културног идентитета треба да укључи и постојање заједничких културних одлика које симболички омеђују друштвену - у овом случају националну групу. У те културне одлике спадају бројни елементи - од језика па до националних симбола, од културне традиције до националне уметности. Културни идентитет обухвата: место, род, порекло/расу, историју,

27 Миленко Бодин, Теоријски основи менащмента нащионалне безбедности, докторска дисертација, Факултет безбедности, Универзитет у Београду, 2007.

28 Драган Коковић, Жолт Лазар, „Чиниоци неговања националног и културног идентитета у Војводини“, Социолошки преглед, Vol. XXXVII, бр. 1-2, 2003, стр. 49-59. 
националност, сексуалну припадност и опредељеност, религијска веровања и етницитет.

\subsection{4 Безбедност}

Безбедност се узима као полазна основа за сагле́дање функционисања односно стабилности једног друштва. Сви концепти безбедности у себи садрже интерес да се преживи, да се сачува идентитет и да се даље развијају појединац, друштвена група, држава или неки други ентитет. Најшире постављен оквир, са владавином права и са свим општеприхваћеним и општепознатим грађанским и осталим слободама, нужна је претпоставка за испуњавање безбедности и сигурности појединца, без обзира на то да ли се посматра као индивидуа или део неке групе и заједнице.

Безбедност се може сагледати у контексту могућности и способности једног друштва или државе да сачува своје вредности и своје особености, упркос променљивим условима и стварним или могућим претњама. Када се говори о социјеталној безбедности, она се односи и на трајност традиционалних језичких, културних схема у пољу језика, културе, асоцијација, идентитета и националних и верских пракси, укључујући и неминовне промене које се сматрају прихватљивима. Без обзира на теоријску оријентацију, сваки приступ безбедности подразумева и одржавање и заштиту добробити припадника датог друштва, онако како је дефинишу чланови тог друштва или сама култура.

Видели смо како су појам културе и колективног идентитета, нарочито националног идентитета, тесно повезани, па је стога неопходно бити веома пажљив у повезивању културе и безбедности (поготово националне безбедности), јер култура врло често изазива изузимање уместо укључивања, а и безбедност која се спроводи у име културе понекад може да има врло негативне последице. Зато смо у овом раду покушали да одговоримо на питање како се производи безбедност, да утврдимо однос између културе, идентитета и безбедности, или то како се култура и идентитет интегришу у безбедност. Процес произвођења безбедности подразумева становиште по којем безбедност 
није само „добро“, вредност или једноставна датост, већ је и друштвена конструкција која настаје, неретко, и у процесу секуритизације. ${ }^{29}$ Овај процес „производње“ укључује одлуку о томе шта је референтни објекат безбедности, дефинише претње за безбедност референтног објекта и утврђује средства или начин да се оствари његова безбедност.

При дефинисању појма безбедности мора се уважити теоријски контекст, али исто тако и време када настаје, амбијент у којем настаје, узимајући у обзир његову уоквиреност правним, политичким и културним чињеницама. То даље значи да се безбедност може представити и као цивилизацијска категорија, која је базични елемент како националних тако и међународних пројеката развоја.

За нормално функционисање једног друштва, државе или заједнице неопходан и приоритетан услов свакако представља безбедност, али да би се он испунио, нужно је, између осталог, развијати безбедносну свест свих чланова заједнице. Она подразумева постојање потребе да се заштите, обезбеде, осигурају или одбране одређене вредности, идентификују и распознају ризици и претње угрожавања, утврде снаге и моћи индивидуе или групе (самостално или као део заједнице) која треба да буде заштићена, осигурана и обезбеђена, али и препознају интереси које треба остварити или за које се треба борити. Да би се реализовали задаци који воде том циљу, али и циљевима сарадње међу државама, народима, поштовања права и слободе других, очувања мира и стабилности, неопходно је у континуитету радити на развијању свести о улози и значају безбедности у функционисању једне заједнице, једног друштва и њихових чланова.

Управо је култура та која ће указати на чињеницу да је безбедност важна. То јест, култура ће одредити и означити интерес безбедности као један од

${ }^{29}$ Секуритизаиија је појам који су у теоријско поље студија безбедности увели Оле Вивер и Бери Базан. Представља екстремни вид политизације неког питања у којем секуритизујући актер, по правилу политичка елита, алармира јавност тиме што неку друштвену појаву или процес означава језичким актом, као егзистенцијалну претњу безбедности или опстанку нпр. државе, како би добила легитимитет за спровођење специјалних мера, које, опет, не морају бити само војне мере. Уколико јавност идентификује безбедносну претњу и одобри специјалне мере, видимо пример успешне секуритизације. 
приоритетних интереса који мобилише све ресурсе једног ентитета, према којем и усмерава своје активности. Оног тренутка када најшира заједница прихвати свест о опасностима, појавама и носиоцима угрожавања и буде спремна да успешно одговори на њихово деловање, тада ће и њена безбедност бити значајно унапређена, а изабрани модел понашања постаће део ширег културног миљеа.

Феномен безбедности у односу на културне обрасце добија потпуно нову димензију и усмерава пажњу истраживача на елементе културе који полако потискују традиционалне политичке и економске инструменте и тиме показују њихову неефикасност и неадекватност савременој пракси. Појам безбедности, артикулисан кроз концепт безбедносне културе, тражи ново тумачење и разјашњење, те га је потребно и представити на потпуно другачији начин у условима када је култура та која даје основ свим даљим промишљањима, која одређује и учествује у дефинисању безбедности.

\subsection{5 Национална безбедност, национална култура и национални интерес}

Национална безбедност се може представити као способност државе (нације) да опстане тако што ће заштитити територијални интегритет и суверенитет, остварити политичку самосталност и уз помоћ државних атрибута заштитити своје унутрашње вредности од угрожавања, које може доћи споља или изнутра. Заштита основних вредности друштва полази од активности националних безбедносних структура путем организованог специфичног апарата државе и не произлази искључиво из ефикасности, већ и суштине и функције, као и превенције укупних хуманистичких вредности којима се на цивилизован начин постижу национални безбедносни ефекти у друштву.

Разнолике су културно-теоријске традиције, из којих се могу издвојити и различита значења националне безбедности с обзиром на вредноснонормативни потенцијал њеног садржаја, с једне стране, и фактичке организације системске природе, које постављају националну безбедност у 
контекст позитивноправног и политичког остваривања, с друге. ${ }^{30}$ Свакако да национална култура својим садржајем и својим функцијама утврђује начин на који се национална безбедност изграђује, чува и развија, поштујући значај и одржавање свих важних компоненти нације као ентитета. Да би се то постигло, неопходно је да своје утицаје и деловање усмери тако да се изграђује и одржава одређени степен националне хомогености, да се преносе доминантне идеје у сфери политичког и националног, уобличава и преноси владајући поглед на свет, укључујући вредносни систем и вредносне оријентације, чувају историјска сећања везана за процес настајања националног идентитета, конструише однос са „другима“, изграђују ресурси у материјалном и духовном смислу и слично.

Национална безбедност представља и „угаони камен“ концепта националног интереса, који као искључиву или најважнију вредност којој те́жи најчешће истиче управо национално самоочување, тј. националну безбедност.

Витални национални интерес представља корист, добит и погодност од посебног значаја за опстанак нације без обзира на начин на који се конституисала. Он не може бити предмет преговарања, већ представља крајњу тачку опстанка, за чију је заштиту држава спремна да употреби све расположиве снаге. Интерес националне безбедности може бити интерпретација виталних националних интереса на различитим нивоима испољавања. Национални интереси треба да буду јасно дефинисани и да артикулишу намере нације, које државе реализују активним спровођењем политике на унутрашњем и спољашњем плану, уз мобилисање свих расположивих ресурса.

\subsection{6 Безбедносна култура}

Разумевање концепта безбедносне културе подразумевало би такве безбедносне активности и понашања који проистичу из одговорности и

30 Миленко Бодин: Теоријски основи менащмента националне безбедности, докторска дисертација, Факултет безбедности Универзитета у Београду, Београд, 2007. 
спремности деловања свих субјеката у једном друштву, у складу са стеченим знањима и вештинама, као и прихваћеним вредностима и вредносним оријентацијама, веровањима и изграђеним ставовима утемељеним у датој култури и културном наслеђу. Огледа се у начину на који се најшире схвата окружење, испољава разумевање за динамику друштвених односа (и на појединачном и на ширем плану), уочава важност апсолутне контроле над сопственим добрима (начело суверенитета), начина на који се уочавају и дефинишу опасности/претње, затим одређују интереси и бирају средства или инструменти за деловање.

Безбедносна култура се може разматрати и кроз њене унутрашње и спољашње манифестације. Унутрашње се односе на промишљање безбедности или развој идеје о безбедности, а спољашње на понашање у сфери безбедности, као и однос или приступ безбедности који се превасходно односи на спремност и способност да се одговори на изазове и претње, било у материјалном било у духовном смислу.

Према Љубомиру Стајићу, безбедносна култура је: скуп усвојених ставова, знаға, вештина и правила из области безбедности, испољених као понашање и процес, о потреби, начинима и средствима заштите личних, друштвених и међународних вредности од свих облика и носилаца угрожавана, без обзира на место или време њиховог испољавања. ${ }^{31}$

Према овој дефиницији безбедносне културе, уочавамо да се она одређује у односу на угрожавање, опасност или претње, који су кључне одреднице за успостављање и развијање једног оваквог концепта. У раду би се нагласиле и неке друге, нове димензије које се оријентишу према богатијем систему мотивације за деловање, као што су, на пример, бољи услови развоја и унапређења односа између одређених актера на међународној сцени или унутар државе упркос присутним претњама и опасностима. Такође, указали бисмо на димензију која интегрише разнородне елементе и њихове специфичне

31 Љубомир Стајић: Основи система безбедности, Правни факултет у Новом Саду, Нови Сад, 2011, стр. 59. 
функције, као и поткултуре, и њихове различите улоге, обављајући одређене фундаменталне функције у процесу хуманизације човека и његовог света.

Концепт безбедносне културе има додирних тачака са многим сличним концептима који су разматрани у раду и који уједно могу представљати његово теоријско извориште. Упоређујући их, покушали смо да утврдимо где су тачке сусрета или размимоилажења у сагле́дању предмета којим се баве. Тако, на пример, у односу на стратешку културу концепт безбедносне културе се може представити као шири, јер, пре свега, поседује потенцијал да се развија и примењује у више димензија и аспеката, али и са више расположивих инструмената. У складу са новим, измењеним концептом безбедности, који укључује бројне актере и не креће се у оквиру само војних претњи, стварају се услови који превазилазе могућности, замисли и идеје стратешке културе.

Циљ безбедносне културе је да осмисли, припреми и омогући остваривање безбедности појединца, заједнице и сваког организованог људског ентитета, да се не деси безбедносна катастрофа, као највише и најрестриктивније остварење безбедносне претње, с једне стране, и да се сви актери оспособе да искористе све своје могућности за развој и напредак, с друге стране. Да би се достигло то жељено стање безбедности, између осталог, потребно је ширити безбедносну свест и одговорност на појединачном, државном и глобалном нивоу, и то као константну делатност.

Безбедносну културу смо желели да представимо као једну од најбитнијих категорија савременог концепта безбедности, при чему она конкретно може представљати материјализацију замисли безбедности, а, с обзиром на то да њена пуна афирмација тек предстоји, указали смо на неопходност развијања и пружања подршке истраживањима у тој области. Овај рад сматрамо такође, малим доприносом тим активностима. 


\section{2 Научни значај рада}

Научни значај овог рада се огледа у самој спознаји, опису и објашњењу појма безбедносна култура, који има и своју теоријско-концептуалну димензију. Ова димензија подразумева систематизацију сазнања до којих се дошло из области културе и безбедности те прецизно дефинисање концепта безбедносне културе. У домаћој стручној литератури ова се проблематика није довољно обрађивала, па се у том смислу очекује и стручни допринос овог рада. Значај се огледа и кроз ниво сазнања који ће се остварити овим истраживањем.

Поред примене дескрипције (научни опис), као најнижег нивоа научног сазнања, како би се сазнале спољне стране појава или процеса - у овом случају безбедносне културе - такође ће се применити и научно објашњење, као виши ниво сазнања који треба да утврди зашто су и на основу којих критеријума издвојена трансферна, синтетичка и развојна обележја овог концепта. У овом раду је било битно утврдити везу која се гради између појмова култура и безбедност, утврдити њен смер и интензитет, као и законитост која условљава производ њихове везе, а који се огледа у појму безбедносна култура.

\section{3 Друштвено-практични значај рада}

Оправданост истраживања безбедносне културе свакако је условљена доприносом којим ће резултати истраживања утицати на решавање конкретних друштвених проблема. У овом случају се мисли на проблеме у области безбедности, али који се одражавају и на друге друштвене сфере. Безбедносна култура може послужити као значајно концептуално оруђе и као основ за вођење успешне безбедносне политике, у једном друштву или држави, затим као системски одговор на ризике, средство за решавање конфликата или неке друге проблеме у подручју безбедности. Резултати истраживања ће такође допринети бољем разумевању ове проблематике, што је изузетно важно у сложеним друштвеним околностима, када је рад многих институција, органа и 
служби усмерен ка развијању стратегија које дугорочно дефинишу циљеве развоја, просперитета и напретка којим ће се једно друштво кретати.

Резултати истраживања могу довести и до промена које ће одредити начин на који се поима неко безбедносно питање, са полазиштима и перспективама које дају нов квалитет и нове погледе на третирану проблематику.

\section{4 Теоријско-методолошки апарат}

С обзиром на то да је истраживање по свом карактеру пре свега теоријско, брижљиво је припремљен појмовни оквир у којем се истраживање креће. Анализа појма, тј. теоријске конструкције, важна је како би се теоријски појмови повезали са другим теоријским конструкцијама у појмовној мрежи односне науке или наука и да би се касније појмови претворили у инструменте за прикупљање искуствених података, тј. да би се довели у непосредну везу са искуственим појавама.

Теоријско истраживање се примарно бави каузалним процесима и објашњењима. Фактори (или варијабле) који се узимају у разматрање често су апстрактни или чисто теоријске творевине за које се развијају операционалне дефиниције и индикатори различитих ступњева прецизности и валидности. Група којој је намењено теоријско истраживање јесте релевантни део заједнице истраживача друштвених наука (то јест, углавном научници) у којем се може претпоставити да сви говоре исти специјалистички језик. Дугорочни циљ је развој знања из припадајућих друштвених наука (наука безбедности).

Ова врста истраживања се у суштини бави производњом знања ради разумевања, обично у оквиру једне дисциплине друштвених наука. Сложеност предмета истраживања, која је уоквирена и богатим проблемским пољем, намеће примену више метода и методолошких поступака. Различита, а веома често само у фрагментима тематизована питања релевантна за овај рад условила су комплементарну анализу садржаја који су обрађивани или обухваћени разноликим изворима, као што су: 
- научни и стручни радови који се директно или индиректно баве феноменима културе, националне културе, културне историје, безбедности, националне безбедности и другим сродним појмовима;

- научни и стручни истраживачки пројекти из ове области;

- међународни документи, конвенције, протоколи и извештаји;

- извештаји, зборници са тематских конференција.

Преглед истраживања је пружио синтезу постојећег знања о одређеном питању, на основу свих релевантних доступних истраживања. Овде је повремено било речи о прегледу теоријских развојних токова, који се често стапају са историјатом започетих идеја и не морају имати готово никакве везе са емпиријским резултатима проучавања. Добри прегледи истраживања и теоријских промишљања мултидисциплинарни су, што је примењено и у овом раду, тако да су консултоване многобројне релевантне студије из различитих дисциплина друштвених наука. Нека питања су привукла већу пажњу унутар одређених дисциплина, па су добила и више простора.

Набројани теоријски концепти, који су обухваћени проблемским и предметним приказом, сами по себи указују на мултидисциплинарно научно подручје којим се рад бавио, како је и најављено у уводном делу: од безбедносних наука, преко студија културе, антропологије, до психологије, социологије и политикологије.

Како би проблем био постављен довољно конкретно, иако сложен и општи по тенденцији, методама формалне логике подељен је на потпроблеме применом одговарајућих критеријума. Методама анализе и синтезе дефинисана су решења потпроблема, која су релевантна за домен основног проблема. Истраживање проблема у виду прикупљања информација извршено је, поред већ изложеног проучавања доступне литературе, коришћењем стручних и научних знања и информација, као темеља за дефинисање одговора. Прикупљање информација и дефинисање проблема преплитали су се, тако да је ово резултовало редефинисањем кључних питања и концепата.

У раду су употребљаване следеће опште научне методе и приступи: индукција и дедукција, методе анализе и синтезе, методе апстракције и конкретизације, 
метода специјализације (а у оквиру ње класификација), метода дескрипције, историјско-компаративна метода, генетичка метода, метода моделовања, теорија система као приступ.

Предиктивна индукција је процес мишљења који се користио за закључивање од једне групе појаве на другу групу, нпр. када је реч о безбедности и националној безбедности, при чему се са́мо расуђивање заснива на сличности појава. Индукција која се темељи на аналогном закључивању, код које се мишљење креће од једне ка другој појединачној појави, користила се за артикулацију културе у оквиру безбедности. Каузална индукција коришћена је за анализу узрочно-последичних односа безбедности и културе, националне безбедности и националне културе. Темељ за примену индуктивног приступа били су посматрање и симулација.

Најважнији елементи дедуктивног приступа јесу поступци метода анализе, синтезе, апстракције, генерализације и специјализације, а наводе се објашњења чињеница и правилности, за предвиђање будућег развоја и за откривање нових чињеница и правилности, па представљају претежни стил научног излагања.

Метода анализе је поступак научног истраживања којим се сложени појмови, попут културе и безбедности, рашчлањавају на елементе, како дескриптивно, тако и експликативно, чиме се покушала објаснити безбедносна култура као целина, на основу идентификованих кључних елемената, делова и функција. Апстракција је заснована на анализи, али је анализа, као поступак рашчлањавања, представљала и подвајање посебности предмета и процеса.

Синтезом, као општом научном методом, систематизовала су се знања тако што се сазнање сложене целине (безбедносне културе) схватило преко њених појединачних делова, њиховим спајањем или њиховим стављањем у разне могуће односе и везе.

Специјализација је поступак којим се од општих појмова културе и безбедности дошло до концепта безбедносне културе, утемељеног на аналитичко-синтетичкој методи и апстрактно-конкретној методи. У оквиру специјализације се класификација, као систематизована подела општег појма на посебне, користила у дистинкцији појмова из области културе и 
безбедности. Уз класификацију, потребна је и дескрипција, како би се наведени кључни појмови описали, те додала битна ауторска запажања о предметима и процесима. На тај начин формиран је основ за научну експликацију, са објашњењима о уоченим обележјима и процесима, узрочним везама и односима развоја безбедносне културе.

Метода моделовања послужила је за формирање модела структуре и функционалног модела безбедносне културе. Моделовање претпоставља холистички и проблемски оријентисан приступ, заснован на теорији система, који подразумева динамично јединство међусобно повезаних елемената чија се интеракција одвија по принципима синергизма. На тај начин су посматрани и анализирани и појмови културе и безбедности.

Када је у питању теоријско-епистемолошки део научне методе, односно теоријско-методолошки приступ истраживању безбедносне културе, нагласили бисмо значај увођења истористичког приступа или методе разумевања. Овај прилаз оспорава позитивистички метод - његов принцип у изучавању друштва и друштвених појава, као и начело о епистемолошком јединству природних и друштвених наука, и сумња у могућност и целисходност откривања научних закона о друштву. Наиме, „позитивистичком захтеву за научним објашњењем друштвених појава историзам супротставља захтев за њиховим разумевањем и описом“. У оквиру овог теоријско-методолошког правца постоје два приступа разумевању друштвених појава: субјективистичко и интуиционистичко поимање и схватање разумевања као методе научног објашњења.

Заступници овог схватања, пре свих, В. Дилтај [Wilhelm Dilthey] и Х. Рикерт [Heinrich Rickert] разликују природне и друштвене појаве. По њима, природне појаве су дате човеку својом спољашњом димензијом, коју он уочава и објашњава утврђивањем закона који владају њима. Друштвене појаве су дело човека, не заснивају се на механичкој узрочности, већ на слободној вољи човека и његовој делатности, која се руководи одређеним вредностима и циљевима. Као производ човека, друштвене науке се могу непосредно „осетити“ и „доживети“, па зато те́же разумевању појава, односно утврђивању значаја и смисла друштвеног догађања на основу индивидуалног доживљаја и 
његовог израза. Разумевање се јавља као завршни чин у научном сазнању друштвеног живота.

Разумевање као приступ уводи, а и целовито развија Макс Вебер. ${ }^{32}$ Он сматра да у основи свих друштвених појава ,лежи људско деловање, односно понашање“. Свако друштвено деловање везано је са субјективним значењем које му придају учесници у неком друштвеном односу, а задатак друштвених наука је да разумевањем тог значења објасне суштину деловања, односно понашања. Да би се разумело значење, битно је, с једне стране, схватити унутарњи смисао којим се у разним облицима деловања руководе појединци, тј. како субјективно повезују циљеве и средства помоћу којих те циљеве остварују; и, с друге стране, утврдити мотиве којима се појединци или друштвене групе руководе у свом деловању. У разним културама се на различитим вредностима заснивају и управљају деловања и понашања, а упоредним проучавањем владајућих културних вредности може се утврдити историјска особеност неког догађаја или појаве, разумевањем смисла који им се придаје из угла појединаца или група који долазе из тих култура. Самим тим се може објаснити и разумети какав су утицај они остварили на одређене друштвене, политичке и безбедносне токове и решења која су се доносила у кључним историјским тренуцима.

\footnotetext{
${ }^{32}$ Макс Вебер, Методологија друштвених наука, Глобус, Загреб, 1989.
} 


\section{2 ТЕОРИЈСКЕ ОСНОВЕ КУЛТУРЕ}

Систематизовани покушаји разумевања и објашњења повезаности облика изражавања културе, друштва, историје и човековог саморазумевања довели су и до успостављања теорије културе. Сваки пут када се покушало критички промишљати о културним феноменима, њиховој генези или вези коју граде са другим феноменима - дат је и допринос теорији културе. Теорије културе су настајале и добијале озбиљне обрисе у деветнаестом веку и наставиле да се развијају у двадесетом, али је са̂м термин култура проналазио своје место и у најстаријим филозофским списима и имао своју специфичну генезу све од настанка првих теорија, али и даље.

Да бисмо одговорили на питања која смо поставили већ на почетку, неопходно је на једном дубљем нивоу осветлити природу саме културе и уочити елементе који значајно обликују понашање и усмеравају активности одређених актера у пољу безбедности. Дакле, важно је сагледати културу као систем за организовање и усмеравање људског искуства, при чему поједине културе, као и поједини теоретичари културе, на различите начине поједностављују или „искривљено“ представљају укупни свет стварности и место културе у њему. Наиме, свака култура образује специфичан оквир унутар којег се прикупљају и интерпретирају спољни знаци „реалности“. Профилисање тог оквира омогућавају конститутивни елементи сваке културе, као што су симболи (језик, мит, ритуали), традиција, религија и други, а на теоретичарима и истраживачима је да их распознају, интерпретирају, тумаче и уведу у теоријску расправу.

Начин на који су то радили, услови и полазне идеје који су их мотивисали одредили су и контуре теоријских праваца које су ти теоретичари конституисали и развили. Ширином обухвата више теоријских праваца и концептуалних достигнућа желели смо да прикажемо богатство и ширину 
значаја и величине културе у новијој историји целокупног човечанства, али и појединачних нација/држава.

\section{1 Појам културе и различити теоријски приступи}

Етимолошки се појам „култура“ изводи из латинских речи cultus и colere. Основно значење прве од ове две речи лежи у религијском схватању културе. Насупрот томе, реч colere, која значи „неговати“, „гајити“, „обрађивати“, има шире значење, којем више одговара савремено схватање културе. Суштинско значење речи „култура“ представља оно које, с једне стране, културу схвата као практично-материјални процес неговања сопственог подмлатка, тј. деце и омладине, док, с друге стране, означава неговање земљишта, биљака и животиња. У овом другом лежи корен материјалне културе. Наравно, постоји и значење речи „култура“ које се тумачи као процес неговања душе и духа, тј. односи се на развијање човекових душевних и духовних способности и одлика. Схватање целокупне културе као духовне културе ${ }^{33}$ заправо је њено значење у ужем смислу, у које се убрајају наука, уметност и филозофија.

Глобално се култура често схвата као супротност природи, која није дело човека. Она је свеукупност људских остварења и артикулација, његових историјских, индивидуалних и заједничких, практичних, естетских и теоријских, као и митских и религиозних облика изражавања. ${ }^{34}$ Појам, дакле, обухвата како културу стварања (грчки poiesis) тако и културу делања у етичком смислу (грчки praxis).

Од најстаријих времена па до данас на делу су бројна трагања и покушаји да се објасни појам и оно што чини суштину културе. Кроз историју је постојало

33 „Духовна култура“ може да буде схваћена као ,једно посебно умеће којим се човек подучава како да култивише и усаврши све делове свога духа“. Видети: Луј Доло, Индивидуална $u$ масовна култура, Клио, Београд, 2000, стр. 26.

34 Лексикон савремене културе. Теме и теорије, облици и институције од 1945. до данас, приредио Ралф Шнел, Библиотека Посебна издања, Плато Books, Београд, 2008. 
више раздвојених светова који задуго нису имали сазнања о постојању оних других и који су се тек у новије доба узајамно пронашли и повезали, захваљујући, пре свега, развоју науке и технологије, модерних средстава саобраћаја и средстава комуникације. Разноврсност менталитета старог Египта, царске Кине, Јапана, преколумбовске Америке, народаิ на острвима Океаније, црне Африке пре европске колонизације, па и арапски, турски или ирански исток обогатили су анализу онога што представља културу, дакле суштински универзалну идеју. Њихова гледишта, размишљања и тумачења још су у сенци западног света, који је проистекао из грчко-латинске и хришћанске цивилизације, и који је мало по мало развио концепт модерне културе, о којем се управо у том свету највише и размишљало. Да би се у правом светлу сагледало значење појма културе, неопходан је и њихов поглед на свет (поглед Истока, Далеког истока итсл.) и начин промишљања о овом феномену, што најчешће недостаје у текстовима који се баве овом тематиком.

Амерички антрополози Алфред Кребер [Alfred Louis Kroeber] и Клајд Клакхон [Clyde Kluckhon] у једној студији још 1952. године анализирали су и класификовали чак 164 основне дефиниције културе садржане у антрополошкој и социолошкој литератури почев од 1871. Није тешко замислити колико је овај број повећан у протеклом периоду од 1952. године до данас, нарочито узимајући у обзир и допринос других научних дисциплина које су се у међувремену прикључиле расправама о томе шта је култура. ${ }^{35}$ У нашем случају рад неће бити оптерећен набрајањем свих постојећих дефиниција културе, али ће се указати на неке кључне.

Појам културе проналази своје место још у најстаријим временима. Атина и други грчки градови нису имали речи које би одговарале савременом концепту културе. Али неке су биле блиске: tropos - који је представљао начин или поступак изражавања, затим ethos у значењу „станиште, обичаји, дах или дух“. Тако је Исократ говорио да „треба пре назвати Грцима оне који деле наш ethos

\footnotetext{
${ }^{35}$ Према једној студији, данас се говори о преко 250 дефиниција културе. Видети: Patrick D. Allan, Understanding Military Culture: A Canadian Perspective, McGill-Queen's University Press, Montreal, Canada, 2004, p. 15.
} 
него оне који деле нашу крв“. Значајна је и реч paideia - грчка реч најближа модерном значењу појма култура (paideia - од ње потиче, с мало измењеним смислом, термин „педагогија“). Цицерон је за реч paideia нашао њен најбољи еквивалент humanitas. ${ }^{36}$

У римско доба нема значајног напретка у продубљивању значења појма културе у смислу обогаћивања људског духа. Култура је тада сведена на појам образовања и посматрана је као потреба само изабраних појединаца за изградњом истанчаног укуса и привилегија резервисана за мали број људи. Допринос Римљана је у томе што су извели реч култура из латинског colere узгајати. Ова реч је, као што је напред већ поменуто, схваћена у свом материјалном и техничком смислу: побољшање квалитета поља и земљишта да би се на њима садиле житарице, биљке, дрвеће и воће. Појам културе подразумева и наглашено прожимање културе и религије, посебно кроз значење друге речи, а то је култ [cultus], који се односио на обожавање богова.

Оксфордски речник, први пут 1420. године, помиње културу у њеном фигуративном значењу, при чему представља један шири оквир, проистекао из употребе метафоре, дакле, култура не означава само објект (обрађену земљу), него и активност (култивисање земље). Током XVI века култура је у свом фигуративном смислу схваћена као усавршавање духа и понашања, а уведена је у научни језик. У XVII веку придев ,просвећен“37 коришћен је често, а именица „култура“ и даље је ретко у употреби, углавном уз неку прилошку одредбу (уметничка култура, научна култура). Тек 1691. године у једном делу помиње се култура без прилошке одредбе, у значењу духовног усавршавања.

\footnotetext{
${ }^{36}$ Луј Доло, Индивидуална и масовна култура, Клио, Београд, 2000. Видети шире: стр. 20-21.

${ }^{37}$ Израз просвета је још у XII и XIII веку коришћен у старој српској држави да означи садржаје које носе „култура и „цивилизација“. Наиме, у најстаријим писаним документима (о Св. Симеону и Св. Сави) обилато се користе просвета, просветитель, просветити и слични термини, управо са значењем култивисаности у најширем смислу (техничком, духовном, религиозном, моралном, правном итд.). Са пропашћу српске државе замиру и ови појмови, све до XIX века, када почиње духовна и државна обнова и када се враћају у употребу.
} 
Прва модерна дефиниција појма културе потиче од Немца Самуела Пуфендорфа [Samuel von Puffendorf], који је 1686. године дао једно од тумачења културе по којем: „Култура обухвата све проналаске и уређаје који се примењују у ьудском животу, дакле одећу, језик, обичаје, уметност, а пре свега целу организащију цивилизованих грађанских друщтава, кроз чије је формирање ьудска врста уведена у оквире одређеног поретка. Култура омогућава сваком човеку да достигне истински људски живот захваљујући надметаюу, делатностима и откривању других људи, али такође $и$ захваљујући личним напорима и промишьағима сваког појединца, а захваљујући и божанској инспиращији.“38

Готово осамнаест векова је прошло од употребе тог значења културе, јер ова дефиниција психолошке и религиозне суштине подсећа на реч paideia код Грка. У осамнаестом веку Француска је била та која је преузела улогу да на један смео начин развије појам културе, у њеном фигуративном значењу. Наиме, поједини аутори изнова стичу свест о томе шта представља појам „духовне културе“, што посебно оживљава код Волтера, који препоручује проширење концепта културе, пре свега у име космополитизма. Култури је додељена и њена интелектуална димензија, док дух губи део свог спиритуалног и религиозног значења, а добија рационалистичку, политичку и социјалну ноту. У Немачкој се у XIX веку „култура“ развила у полемички појам, супротстављен француском појму „цивилизација“. У Наполеоново доба цุивилизација је, наиме, била повезана с националним идејама и с универзалном вером у напредак и тумачена првенствено као систем делања. Надовезујући се на начин на који су Имануел Кант и каснија епоха идеализма користили реч „култура“, немачко схватање тог појма стављало је тежиште на унутрашње оплемењење, за разлику од само спољашњег оплемењења, особеног за цивилизацију. ${ }^{39}$ Даљи развој појма културе све је више наглашавао човекова

${ }^{38}$ Антоњина Клосковска, Социологија културе, Чигоја, Београд, 2001, стр. 10.

39 Култура је, дакле, приказивана као унутрашњи, духовни садржај, а цивилизација као спољашња, материјална форма. Оштро супротстављање духа и материје, које је карактеристично за класичну немачку филозофију, пресликало се и на учење о култури. Овакво семантичко разграничавање културе и цивилизације, које су прихватили Тенијес, 
постигнућа, која су током историје нарастала, као и њихов значај за одређени социјални - а махом и етнички - систем повезивања и његове етичке премисе. У посредовању појма културе важну улогу су имали и хуманистичкопедагошки концепти, који су културу ограничавали на тзв. високу културу, изражену кроз одређене облике књижевности и уметности уопште.

Око 1800. године појам добија специфично немачку новину у значењу односно, испуњава се филозофским садржајима. Тиме се сужава просветитељски појам културе, што као последицу има претварање културе у ужем смислу (наука и уметност) у медијум амбициозног концепта образовања. To ће, као својеврсна матрица тумачења, до данашњих дана битно одређивати поглед на свет образованог грађанства. ${ }^{40}$ Током прве три деценије XX века појам културе је на немачком говорном подручју остварио свој највећи филозофски и публицистички развој, и то како на плану утемељења теорија културе, тако и на плану критике културе.

У Русији је реч „култура“ први пут забележена у Џепном речнику страних речи Н. Кирилова 1846. године, у којем је описана као усмерена активност на буђење у предмету успаваних снага и као известан степен развитка те активности. Крајем XVIII и почетком XIX века у теорији филозофије и књижевности у Русији још није пронађена реч „култура““. Данашњи садржај овог појма преносио се у то време речима „образованост“ и „просвећеност“. Код А. С. Пушкина, који није користио термин „култура“, а немогуће је да га није познавао, могло се прочитати: „Поштовање прошлости - ево особине

Шпенглер и Вебер, није било општеприхваћено. Наиме, према Креберу и Клакхону, „број аутора који је култури приписивао материјални и технолошки аспект бар је толико велик као и број оних који овај аспект приписују цивилизацији“. А постоји и одређен број аутора који цивилизацију сагле̄да као наткултурну творевину, највиши стадијум развоја човечанства или стање свести које људи достижу у потрази за идентитетом у једној широј заједници него што је сопствена култура. Видети шире о томе у: Јан Кјенјевич, Увод у историју ичивилизације Истока и Запада, Службени гласник, Београд, 2011.

40 Лексикон савремене културе. Теме и теорије, облици и институције од 1945. до данас, приредио Ралф Шнел, Библиотека Посебна издања, Плато Books, Београд, 2008. 
којом се одликује образованост од дивљаштва.“41 Касније се, у Енцииклопедијском речнику свих наука, који је изашао 1878. године, о култури говори као о духовном и материјалном развитку земље, а појмови „култура“ и „цивилизација“ посматрају се као синоними.

Недефинисаност термина „култура“ довела је до сумњичавог односа према њему код појединих теоретичара у првој половини XX века. Без обзира на то, термин је прихваћен у научној литератури у већини земаља, и то у холандском, скандинавским и словенским језицима, а потпуно се учврстио у Шпанији, Италији и Америци, док је једино у Француској и Енглеској наилазио на известан отпор. Према неким тумачењеима, језик науке је у ове две земље већ био довољно развијен у тренутку рађања науке о култури, па је из тог разлога имао мању потребу за туђим позајмицама, нарочито немачким.

Након Другог светског рата појам се користи у знатно ширем значењу и, како је представљено у Лексикону савремене културе (објављен у Немачкој 2000. године, преведен код нас 2008. године): 1. преноси се на културу свакодневице (популарну и масовну); 2. укључује се разумевање света засновано на природним наукама и техници; 3. подразумева глобалну критику културе и цивилизације, а наглашава се повезаност економских и културних аспеката; 4. евроцентрично разумевање културе шири се концептима мултикултуралности, интеркултуралности и транскултуралности, што је и реакција на све масовнија миграциона кретања и с њима повезану културну неједнозначност, која је у вези с различитим националним, језичким и етничким коренима културе. Затим, 5. разумевање културе оријентисано на главна струјања шири се и укључивањем посебних, раније само маргинално или недовољно опажених култура, што се најбоље огледа кроз студије рода или истраживања култура искључених групација (сексуалних мањина, верских, етничких итсл). 6. Естетичке теорије развијају се као саставни делови опште теорије културе. 7. Разумевање културе проширује се и укључивањем политичких теорија, као и кроз политичку праксу и с њом повезане захтеве за успостављањем културе политичког деловања. 8. Разумевање културе се све више повезује с променама

\footnotetext{
${ }^{41}$ Е. В. Соколов, Култура и личност, Просвета, Београд, 1976.
} 
у оквиру медија, где се укључују појмови као што су медијско друштво, медијска култура и медијска екологија, који припадају контексту новог културног саморазумевања.

Дакле, крајем XX века култура се више не схвата на известан исувише интелектуалан и књижевни начин, њен домен се проширује и на друге вредности, што неизоставно отвара и нове расправе које иду у прилог или против таквог тумачења. Током деведесетих година XX века појам културе доживљава даљу диференцијацију кад год неки облик културног испољавања добије култни статус и повеже се с ритуалним облицима самоинсценирања. Култура тада почиње да се опажа и као део такозваног event-a. ${ }^{42}$

Није једино тумачење термина „култура“, већ и покушај разумевања саме суштине културе имало током времена бројне тумаче, теоретичаре и истраживаче који су се трудили да прегледно и повезано изложе своје схватање културе, методе њеног научног истраживања, да изведу дефиницију културе као објекта научног истраживања и науке као инструмента истраживања културе. На тај начин су желели да конституишу максимално доследну и кохерентну, неком себи својственом логиком повезану схему свих битних чинилаца и њихових међусобних односа који учествују у динамици настанка и развитка културе и културних феномена. Тај процес, наравно, није завршен, па се и надаље очекује да будућа промишљања и идеје које творе културу такође буду плодоносни и конструктивни.

42 Појам који означава догађај, често инсцениран у рекламне сврхе, који директно укључује рекламирани производ или ствара оквир којим се повећава пријатност куповине, а у крајњем случају и са̂м може представљати производ. Посебно у сфери пружања услуга event има широку примену као инструмент за привлачење купаца и посетилаца. У оквиру социологије говори се о преображају потрошње као снабдевања у потрошњу која представља доживљај, те се савремено друштво дефинише и као друштво доживљаја, у којем постизање жељених осећања и расположења више није ствар појединца, већ се циљано производи „догађањима“. Event (тј. Ereignis) представља и један од кључних појмова модерне филозофије и означава непредвидљив догађај који трајно мења дату структуру мишљења (Хајдегер). 
Да бисмо у овом раду представили и посебне теорије и теоријске правце који су за предмет проучавања узимали културу, могу се применити различити критеријуми, опет условљени потребама истраживања и идејом коју желимо да развијемо. Тако, на пример, то могу бити и два дихотомна принципа којима је могуће руководити се у том послу: рационални и ирационални, који одређују и два општа усмерења теорије културе, условно подељена на: а) рационалистичке и б) метафизичко-ирационалистичке теорије.

Методолошки посматрано, рационалистичке теорије су у приступу „култури“ оријентисане емпиријски, што значи да „културу“ схватају као историјску, објективну, чињеничну датост. Ирационалистичке теорије, међутим, сматрају да иза појавне манифестације датости „културе“ треба открити њен метафизички темељ, који се налази испитивањем њених дубљих структура, пре свих емоционалних и колективнодушевних носилаца и покретача. У представљању теорија културе негде ће се поштовати овај дихотомни принцип, а негде ће се издвојити начин на који се тумаче одређени елементи културе, као што су традиција, промена/напредак и идентитет, или којима се даје предност или важност у тумачењу и објашњавању самог појма културе. На крају ћемо извести хуманолошки приступ култури, који ће послужити као основа за даље развијање концепта културе у пољу безбедности и кроз концепт безбедносне културе.

\subsection{1 Антрополошки приступ}

Антропологија, као наука о човеку уопште, као најобухватнија дисциплина хуманистичких наука, међу последњима је почела да се бави истраживањем људске природе, човекових рукотворина и односа међу људским бићима. Пре ње су то учиниле филозофија, теологија, историја, економија и право, политичка наука и естетика, лингвистика и археологија, али и упоредно проучавање религија, свака дисциплина на сопствени начин.

Антрополошки појам културе, својим истицањем заједничких одредница културе једне заједнице, занемарује унутардруштвена разликовања у 
културном пољу и преко социологије, антропологије и културних студија дефинитивно разбија јединство „културе“ у оквирима једног друштва у мноштво посебних „култура“. У XIX веку култура је обликована у суштинском - антрополошком смислу. За антропологију је култура темељни појам и преко ње антрополози схватају друштво као компликовани однос између заједничко̄г, опште̄г и различито̄г - особено̄г у људској врсти.

Главна разлика у односу на хуманистички појам културе јесте да од нормативног он постаје општи појам. Антрополози описују културу чињенички онако како је налазе искуствено у разним друштвима. ${ }^{43}$ Од самог почетка културу поимају на различите начине, па је тако за неке оруђе за задовољавање материјалних потреба стварног живота, а за друге је од њих независна, опет за неке елементима културе се људи служе и манипулишу, а за поједине ауторе основна начела културе леже на несвесном нивоу. Наредни теоретичари је сматрају одразом садашњих околности или, опет, неки следећи на основу учинка других историјских случајности.

Франц Боас [Franz Boas], иако се остварио као амерички антрополог, заправо је најзначајнији представник немачке теорије о „култури“. Овај аутор полази од става да свака култура - било којег народа - има своју прошлост и одликује се „својом властитом једноставном историјом“. По њему је економија, технологија, или оно што Немци по традицији зову сфером цивилизације нуспроизвод Идеја. Идеја, сфера културе [Kultur], чини битно средиште једног народа. Ова теза је потпуно супротна схватањима Леслија Вајта [Leslie Alvin White], који сматра да се водеће начело динамике културе налази управо у технолошкој сфери, у материјалној култури, док су идеацијски елементи - што

${ }^{43}$ Модерна антропологија се све више конституише као наука која проучава не само начин на који људи живе, доживљавају и сазнају или интерпретирају своју праксу и њене учинке, стварајући властите специфичне оквире оријентације и упутства за живот, што чини садржај културе као људског света. Све више постаје интерпретативна наука, таква у којој је кључни проблем значење, а не сама појава. Ослања се на херменеутички приступ, што значи да проучава и начин на који се људи разумеју и интерпретирају свет у којем живе, каква значења придају предметима које употребљавају и како их осмишљавају или тумаче. Више о томе ћемо сазнати у вези с конструктивистичким приступом култури. 
је само друга ознака за форме културе: уметност, религију, митологију секундарни изрази и нуспроизводи технолошког развоја.

Боас је пренагласио идеју о културном детерминизму, тј. о култури као пресудном фактору - који аутоматски делује на укупан друштвени, политички и материјални развој, на структуру друштва, економију и технологију - да се конституише и одређени недвосмислени закључак. Према Боасу, „Политичка промена у једном народу првенствено је ограничена идејама којих се тај народ држи, пре неголи структуром датог друштва, деобом моћи или природом привредног уређења“. 44

На рад Боаса је утицала немачка традиција идеалистичког мишљења, која је више истицала субјективну идеју него објективну, појавну стварност. Док су се природне науке бавиле појавним светом на материјалистичкој основи, идеалисти су сматрали да се области људске делатности може приступити једино кроз њена „спиритуална“ или субјективна својства. Историју при томе не треба схватити као разраду природних и свеопштих закона, већ као изражавање идеја. Geist, или „дух“, постаје устројавајуће начело за податке историчара, a тај Geist је био не́ма, субјективно доживљавана целина. Мислило се да свака културна традиција и свако раздобље поседују свој властити јединствени „дух“, који се квалитативно разликује од сваког другог, а човек из једне традиције кадар је да појми догађаје и „дух“ неке друге искључиво посредством субјективног разумевања. Немачки идеалистички писци тежили су да примењују један од два приступа: или су се усредсређивали на филозофију историје, или су за свој циљ узимали до ситница подробне историјске извештаје, наумљене да пруже најпотпуније могућно знање или разумевање једног датог раздобља или догађаја.

Супротно Тајлоровом [Edward Burnett Tylor] еволуционизму и његовој критици традиције, Франц Боас уважава и традицију и осећање као битне полуге и као динамичке факторе културе. Док је Тајлор веровао да принципи традиције и осећање, ако су уопште од некаквог значаја, важе само за примитивно друштво,

\footnotetext{
${ }^{44}$ Елвин Хач, Антрополошке теорије 1, БИГЗ, Београд, 1979.
} 
Боас тврди супротно: „Чак и у нашој цивилизацији, уобичајено мишљење првенствено се усмерава чувством [осећајем], а не разумом. “45

Слично гледиште о доминацији осећања и вредности културног система, или тзв. сфери идеја, налазимо код Рут Бенедикт [Ruth Benedict ${ }^{46}$ или код Алфреда Луиса Кребера. За Бенедиктову је осећање појединца одлучујуће у разјашњењу суштине културног система, културне установе, док је разум сасвим споредан чинилац. Основни појам којим се Рут Бенедикт бавила у теорији културе јесте концепт културног обрасца. Затечени „образац“ предодређује положај сваког новог члана у извесној заједници, он утиче на његова посматрања, оцењивања вредности других.

Бенедиктова је у својим делима истакла да је „животна историја сваког појединца на првоме месту и пре свега прилагођавање обрасцима и мерилима који се у његовој заједници преносе с колена на колено. Од тренутка његовог рођења обичаји света у којем је рођен уобличавају његово животно искуство и понашање. Кад почне да говори, он је мало створење своје културе, а кад одрасте и оспособи се да узима учешћа у активностима те културе, њене навике биће његове навике, њена веровања његова веровања, њене немогућности његове немогућности.“ Дакле, жели да каже како људе међусобно истински повезује „њихова култура - идеје и мерила која су им заједнички“. 47

Рут Бенедикт је имала један интеграцијски приступ култури који је искључивао проучавање културних установа изван њиховог ширег контекста. Сматрала је да се сваки одељак културе мора сагледати у контексту целине, будући да је

${ }^{45}$ Исто, стр. 76.

${ }^{46}$ Рут Бенедикт, као еминентна представница теоријске школе култура и личност, радикално раскида са дискриминаторском традицијом у којој се веровања и поступци тзв. примитивних (незападних) народа процењују мерилима деветнаестог века. По њеном мишљењу, тешко је разумети било коју културну одлику када се она издвоји из општег склопа. Али, такође истиче међудејство које се одвија између културе и појединца: „Ми морамо схватити јединку онакву каква живи у својој култури, али и културу онакву каква живи кроз јединке.“ Видети: Рут Бенедикт, Обрасии културе, Просвета, Београд, 1976.

${ }^{47}$ Исто. 
део ширег система интегрисања, подвргнут начелима која владају том целином. Природа културе sui generis, према Бенедиктовој, значи да културу ваља схватати с обзиром на њена унутрашња начела, а ова су релативно независна од спољних утицаја. Та самосталност културе јавља се у њеном делу као спорно питање у два различита контекста: у њеним гледиштима у вези културе са средином, с једне, те културе с личношћу, с друге стране.

Такође, издвојила је два нивоа на којима се одвија процес интегрисања: ниво културних одлика и ниво стварања чувствених [осећајних] образаца. Она је нагласила да се елементи културе јављају у бесконачним комбинацијама. У једном друштву се неки особен елемент културе, попут какве уметничке форме, може утопити у религијски систем, док у другом друштву иста одлика може да се одреди као драгоцено добро, те да тако постане део система економске размене. Могућности су безбројне и усклађивања су често чудна. Међу гледиштима Бенедиктове о интеграцији уочава се њен став како је важно да нема две културе које су сличне. Облик интегрисања једне културе случајан је, будући да је производ готово произвољних и неограничених преспајања, накнадних тумачења и разраде културних одлика.

Други ниво на којем је Бенедиктова сагледала интеграцију културе јесте ниво осећаја или емоција. Наиме, она је трагала за неким апстрактним оквиром који би осмислио оне опште обрасце што, чинило се, прожимају сваку културу, тражила је неко „уцелињујуће начело“, којим би се објаснило јединство културе, за које је осећала да постоји. Тако је у једном тренутку уочила да се разлике међу културама могу објаснити као и разлике међу људима: попут неког појединца, свака култура понаособ те́жи да се одликује особеном нарави; Бенедиктова је то уцелињујуће начело назвала етосом или конфигурацијом културе. ${ }^{48}$

Важно је уочити и следећу чињеницу на коју указује Рут Бенедикт, а то је да не сматра културу производом било којег појединца: она је примарна - док је појединац мање-више њен извршилац. Можемо знати све о распрострањености

48 у суштини, ово начело је један емоционални образац; он се садржи у извесној осећајној склоности или ставу, који временом тежи да прожме дату културу. 
једног племенског облика брака, о обредним играма, као и о церемонијама у вези с пубертетом, па да ипак ништа не разумемо о култури као целини која се служи тим елементима за свој сопствени циљ. У чему се онда огледа значај проучавања тзв. културе примитивних народа? Као једно од филозофских оправдања Рут Бенедикт истиче следеће: „Чињенице најједноставнијих култура могу учинити јасним друштвене околности које иначе изазивају недоумицу и нису приступачне доказивању.“ У томе се огледа и највећи значај проучавања примитивних друштава којима су се антрополози посветили још од XIX века.

\subsection{2 Теорије културне еволуције}

Еволуционизам, као појам који везујемо за биолошке науке и који се концептуално односи на постепен и лаган развој сложеног организма од једноставних ка сложенијим облицима, преноси принцип еволуције и на област културе и уметности. Представници овог теоријског правца, као што су: Тејлор, Луис Морган, Спенсер и Бастијан, сматрају да су разлике међу разним културама у основи само квантитативне разлике - тачније, само разлике у „степену развитка“.

Едвард Барнет Тејлор је најпознатији представник еволуционистичке теорије „културе“, односно „цивилизације“, пошто је у енглеској и америчкој антропологији употреба једног термина ствар личног избора, а не појмовна, семантичка разлика. Наиме, Тејлор сматра да се „цивилизација“ развија на подлози разума и научног сазнања, и да „цивилизација“ стоји у месту када њоме управља древни обичај који намећу прадедови. ${ }^{49}$ Тејлор се, дакле, радикално супротставља сваком виду традиционализма, а признаје само поступан, али сигуран напредак у развоју.

У свом најпознатијем делу, Примитивна култура [Primitive Culture], Тејлор је установио извесна теоријска начела, међу којима је и оно које истиче да културом човечанства владају одређени закони еволуцијског развоја. У

${ }^{49}$ Edward B. Tylor, Anthropology: An Introduction to the Study of Man, New York, 1881, p. 430; према: Елвин Хач, Антрополошке теорије 1, БИГЗ, Београд, 1979, стр. 33. 
међувремену је опречна мишљења код теоретичара̂ културе изазвала управо сама одредница „примитивна“. Наиме, иако је признато да су све друштвене групе, дакле и дивљи или примитивни народи, ${ }^{50}$ способни да стварају „културу“, остала је недореченост у термину, која је захтевала нову концептуалну разраду. Она је касније и урађена признавањем постојања не само једне већ мноштва културних могућности, па самим тим и до признавања плуралитета култура, које се не могу процењивати на основу исте скале вредности.

Тејлор је људске установе поимао с обзиром на међудејство двеју опречних сила - конзервативних окова традиције, с једне, и прогресивног, рационалног мишљења, с друге стране. Он је конзервативизам држао за болесно стање и показивао је мало саосећања кад није наишао на такав пример. Неки антрополози, попут Диркема, сматрали су основе традиције кориснима; по Диркему сила традиције доприноси кохезији и постојаности друштва. Други антрополози, укључујући Рут Бенедикт, били су склони да се према конзервативизму односе неутрално. За њу је традиционализам, просто, животна чињеница - можда неповољна у неким случајевима, али не у већини. За Тејлора историја човечанства јесте сведочанство достигнућа, а спутавајући окови традиције оличавају антитезу и разуму и напретку. ${ }^{51}$

50 Вековима су још од времена великих географских открића, представе о примитивним народима које су стизале на Запад и одговарајуће идеологије говориле или о „нељудском“, или о „човечанству које је Бог напустио“, изопаченом и грешном, па га треба казнити или избавити помоћу ропства и присилног рада. То је било покриће за покоље, истребљења, израбљивање и владавину везану за рани колонијализам, који се још назива „освајачки“ или „Пљачкашки“. У међувремену је прихваћено становиште по којем култура примитивних народа не само да није одраз изопаченог човечанства или пуке анималности, већ је то култура која је била својствена и цивилизованим народима у почетним фазама њиховог развоја. Према: Уго Фабијети, Роберто Малигети, Винченцо Матера, Увод у антропологију, Клио, Београд, 2002, стр. 54.

51 Илустративан пример традиционалног конзервативизма чини једна етничка групација, Дајаци, која живи на Борнеу. Када су их Европљани упознали с једном бољом техником сече дрвета, Дајаци су јој се толико одупирали да су одредили глобу за свакога ко буде ухваћен да се њоме служи. Надмоћ те европске новине, међутим, била је тако очигледна да 
У основи сваког еволуционизма и интелектуализма налази се борба против традиционализма и културног партикуларизма. Према истом аутору све културне установе које се ослањају на традицију у својој основи су „нестабилне“, па самим тим културне установе које нису утемељене на разуму треба искорењивати као неуке традиције. Основни став интелектуалистичког приступа култури и друштву, гласи: било да је реч о јединки или о људској групи, у подручју културе свако се мора понашати коришћењем „рационалног начела“. Традиција се, додуше, може дуго одржавати, по сили инерције и навика, „али ће коначно ипак устукнути пред разумом““.

Немајући разумевање за идеју традиције, а поштујући схему еволуционизма и непрекидног развоја установљеног на разуму, Тајлор је био склон да каже како свуда где се сусрећемо са тзв. феноменом „тираније традиције“ - уочавамо поуздан знак да пред собом имамо развој у којем није победио разум. Његова основна теза гласи: „Што је нека култура на нижем ступњу, утолико су и закони традиције јачи.“ И обратно: на вишим ступњевима цивилизације људи желе да „свесно побољшају своје установе“ да их „разумом превладају“, док „међу нижим расама постоји тврдоглав отпор најпожељнијим реформама““.

Лесли Вајт је даље унапредио еволуционистичко схватање културе и идеју о утилитарности културе. То у основи значи да су културне установе у својој суштини корисне, да је њихова сврха да се за људску врсту живот учини „безбедним и трајним“. ${ }^{52}$ Вајт сматра да друштвена група ствара културу, па је и значајнија од појединца. Самим тим „појединац није релевантан за актуелни културни прогрес“, већ за „објашњење културног процеса“. Управо због тога он и сматра културу као реалност, тачније као датост која је унапред дата човеку, па је зато култура биће sui generis.

су се многи Дајаци њоме кришом користили. Тајлор тај случај описује као „запањујући пример опстанка (обичаја)“ посредством ауторитета старине, насупрот „пуком“ здравом разуму. Видети: Edward Burnett Tylor, Primitive culture, I, p. 71; према: Елвин Хач, Антрополошке теорије 1, БИГЗ, Библиотека XX век, Београд, 1979, стр. 48.

52 Лесли Вајт, Наука о култури, Култура, Београд, 1970, стр. 156. 
Тако се култура сагле̄да као објективност изван и изнад човековог осећајног живота. „Не одређују људска бића културу по жељи и замисли, управо култура одређује понашање људи. “53 А култура се мења и развија у складу са властитим законима, не повинујући се човековој вољи или жељи. Једна наука о култури открила би природу и смер процеса културе, али човеку не би дала у руке и моћ да надзире или усмерава његов ток. ${ }^{54}$

У време кад је већина америчких антрополога одбацивала еволуционизам и кад се мало ко бавио трагањем за природним законима који се налазе у основи културе, Вајт је предлагао једну еволуциону и научну теорију културе. При образлагању Вајтовог мишљења нужно је повући разлику између његове две употребе термина „култура“. Прво значење односи се на културу човечанства као целину, на укупан збир културних одлика широм света. Друго значење се односи на посебне, омеђене видове те целине, као што су културе Индијанаца Пуебло и Шошона. Дакле, култура човечанства као „,јединствен, самодовољни, затворени систем“ насупрот појединачној култури, која не може да буде самодовољна, јер на њу непрестано утичу месна средина и увођење туђих одлика, из других друштава.

Вајтова еволуциона теорија темељи се на идеји да су установе у основи корисне. Попут свих животиња, човек мора да се споразуме са спољашњим светом. На пример, мора да себи обезбеди храну и мора да се брани како од природе тако и од непријатеља. Животињске врсте се прилагођавају употребом својих чулних органа, мишића̂ и томе сличног, док човек развија културу као додатно средство прилагођавања и надзора, јер су сврха и функција културе, као што је већ напред речено, да се за људску врсту живот учини безбедним и трајним. $^{55}$

\footnotetext{
${ }^{53}$ L. White: Individuality and Individualism: A Cultural Interpretation, Texas Quarterly, 1963; према: Елвин Хач, Антрополошке теорије 1, БИГЗ, Библиотека XX век, Београд, 1979, стр. 187.

${ }^{54}$ Исто, стр. 185.

${ }_{55}^{55}$ Оно што је изгубљено од безбедности за коју јамчи природа надокнађено је преимућством веће довитљивости. Људском бићу неће, као медведу, са́мо израсти поларно крзно да би се, после више генерација, прилагодио Северном полу. Он учи да са̂м сашије крзно и да
} 
Међутим, нису сви видови културе једнако важни за човеково уклапање у свет. Према Вајту, културу сачињавају четири одвојена дела; први је технолошки, укључујући особине као што су оруђа, средства за опстанак и помагала за напад и одбрану; други је социолошки сектор, или обрасци међуличних односа; трећи, идеацијски сектор обухвата културне идеје и веровања; најзад, последњи - сектор ставова - обухвата осећаје....

Технолошки део је најнепосредније укључен у процес прилагођавања; услед тога је он и најосновнији, те одређује остале бар на неки општији начин. Али ни друге особине (елементи) културе нису без вредности. Веровања и обреди, на пример, пружају човеку „неки осећај моћи и поуздања“, помажући му тако да надвладава патњу, осујећења, страх и досаду, с којима се стално суочава. Можда су међу функцијама не-технолошких саставница културе најважније оне које доприносе делотворности технолошког система. Вајт напомиње да би се друштвени систем чак могао дефинисати као „начин на који се једно друштво користи неком посебном технологијом у разним процесима одржавања живота“. Идеацијски систем пружа знање потребно за остваривање датог технолошког система. Веровања и осећања такође испуњавају важне функције у вези с друштвеним системом; она, на пример, унапређују друштвену солидарност, што је предуслов за технолошко предузетништво.

Пошто људска бића поседују културу, сваки је нараштај кадар да своја унапређења пренесе следећем колену. Човекова култура је прогресивна и иде ка све већој власти над природним силама, ка потпунијој безбедности живота за човека. Тај процес еволуције је sui generis: „Култура има свој посебан живот, којим управљају његова властита начела и властити закони. Трајући столећима, она припаднике сваког нараштаја обухвата на самом рођењу и обликује их у људска бића, опремајући их веровањима, обрасцима понашања, осећањима и ставовима. Људско понашање је само одзив једног примата кадрог да

подигне кућу од снега. Према свему што можемо научити из историје интелигенције у прељудским, као и у људским заједницама, та довитљивост је била тло са којег је потекао и на којем се одржао људски напредак. 
симболизује на основу тог вантелесног континуума који називамо културом. Култура је систем који расте увећавајући свој надзор над силама природе.“56

Представницима класичног еволуционизма, који су једноставно надовезивали друштвено-културну еволуцију на биолошку, недостајали су основни елементи да би се установио прави смисао појма еволуције у области људског живота и да би се пронашли суштински критеријуми за утврђивање степена еволуционог развитка. Извесне аналогије које су се повлачиле наступале су у време када друштвене науке још нису успевале да се осамостале од природних и да се оспособе да схвате својеврсност друштвених појава. Управо је упознавање са нецивилизованим народима потврђивало уверење о непрекинутој ниิти између природног и друштвеног развитка. Једноставне облике друштвене организације антрополози су, упоређујући их са сложеним друштвима савремене цивилизације, свели на ,јједноћелијски“ облик људског живота.

Кребер је био тај теоретичар културе који је значајно допринео да се питање о људској еволуцији постави на потпуно друкчију основу. ${ }^{57}$ По њему органска/биолошка и друштвено-културна еволуција не представљају јединствен континуирани низ, већ се у једној тачки историјски разилазе. Тако је и претпоставио да се друштвено-културни развитак, као еволуција људског света, не може посматрати у истој равни у којој се одвија биолошки развитак органског света. Из те претпоставке је произашло да се принципи друштвенокултурне еволуције не могу сводити на принципе биолошке еволуције, да су фактори еволуционог развитка људског света сложенији и не могу се изводити из биолошке природе човека, а механизми и преносиоци промена у друштвенокултурној еволуцији разликују се од механизама природне мутације и селекције.

Полазећи управо од овог последњег, можемо рећи како је свесна и смисаона селекција коју врши човек у току свог развитка знатно сложенија од

\footnotetext{
${ }^{56}$ L. White, Ethnological Theory, p. 379; према: Елвин Хач, Антрополошке теорије 1, стр. 182.

${ }^{57}$ A. Kroeber, C. Kluckhon, Culture, Random House, New York, 1963; према: Загорка Голубовић, Антропологија, Службени гласник, Београд, 2007, стр. 141.
} 
селективности биолошке еволуције. Наиме, циљ селекције у биолошкој еволуцији јесте да се преживи, а код човека је мотив одабирања неке вредности задовољење многостраних потреба и води усавршавању људске врсте, а не тежњи да се преживи.

\subsection{3 Еколошки приступ}

Еколошки приступ култури подразумева проучавање прилагођености културе или њеног односа с природном средином. Ту су обухваћена два одвојена реда појава: особине саме природне средине и културна „изградња“, кроз коју се та средина експлоатише, укључујући технологију и устројство привреде. У културно-еколошкој анализи морају се узети у обзир оба скупа појава.

Џулијан Стјуард [Julian H. Steward] друштву је приступао кроз испитивање његове екологије, како би открио начин на који тај еколошки оквир одређује друге особине дате културе. Иако је екологију сматрао значајним узрочним чиниоцем у основи друштвених установа, Стјуард је јасно истицао да се еколошким прилагођавањем не могу објаснити све особине културе. Он је разлучивао културно језгро, „скупину особина најприсније повезаних с делатностима у сврху опстанка и с привредним уређењем“ - особине као што су политичко устројство и, у неким случајевима, религијски обрасци - од другостепених особина културе, оних који нису снажно везане за језгро и које су у „већој мери одређене чисто културно-историјским чиниоцима насумичним новинама или дифузијом“. Ова разлика је једнака оној коју је Кребер повлачио између стварносне и вредносне културе. ${ }^{58}$

\footnotetext{
${ }^{58}$ У оквиру стварносне културе Алфред Луис Кребер је обухватио стварност која представља технички, стварносни аспект културе, самосредство, утемељење на објективним и спољашњим условима и емитовање кумулативне (еволутивне) димензије културе. Вредносна култура представља могућност, дакле систем идеја унутрашњег аспекта културе, темељи се на субјективним и унутрашњим начелима и емитује креативну димензију стварности.
} 
Стјуард је сматрао да узрочни и еколошки оквир пружа довољну основу за једну теорију еволуције културе. Боас и већина антрополога којима је он предавао сматрали су да свака култура има јединствену и сложену историју, а да закони еволуцијске промене или не постоје или су исувише сложени да би били откривени. Према Стјуардовој схеми, међутим, разне природне средине нужно намећу различите форме прилагођавања, тако да би разне културе у сличним срединама требало да испољавају и сличне обрасце развоја.

Једна од идеја које су се присно повезале са Стјуардовом теоријом еволуције јесте његов појам нивоа друштвено-културне интеграције (уцелињености). Он је сматрао да разлике између једноставних и сложених друштава нису тек квантитативне и „системи вишег нивоа не садрже само већи број уразноличених делова“. Сложени системи се пре квалитативно разликују од једноставних, јер разни нивои сложености подразумевају из основа различите форме интеграције и прилагођавања. Он је запазио да је еколошки приступ мање применљив на сложена него на примитивна друштва, пошто је друштво с истанчаном технологијом слободније (независније) од срединских ограничења, па самим тим располаже ширим опсегом могућности.

Два елемента Стјуардовог мишљења наводила су га да првенство даје пре екологији него идејама. Први је било схватање да је култура омеђена скупом објективних и крутих услова. Култура може да буде подложна неочекиваним варијацијама, којима владају субјективна начела, али одлика која дође у сукоб са системом одржавања живота напросто се мора прилагодити. Чак и ако један народ разрађује церемонијалне или уметничке особине своје културе радије него средства за одржавање живота, он своја културна занимања може да следи једино у оквиру граница које му поставља еколошка основа. Сходно томе, промене у систему обезбеђивања средстава за живот често ће наметати нужне промене у другим особинама културе, док се обратно дешава ређе.

Други елемент Стјуардовог мишљења тиче се практичне представе о човеку, по којој ће питања опстанка појединац по правилу претпоставити обзирима мање важним за живот, те ће нееколошке особине културе морати прве да устукну уколико би између поменутих одлика дошло до несагласности. Услед оба ова 
чиниоца, проблем еколошког прилагођавања склон је да претежно утиче на културу и стога је екологија кључ за интегрисање и промену културе.

\subsection{4 Функционализам}

Еволуционизам је готово у потпуности био ослоњен на почетне успехе дарвинизма и његовог еволуционог и историјског тумачења биолошког развоја порекла врсте, па је временом почео и да застарева. Унутар исте оријентације, која се ослања на рационалне капацитете у тумачењу културе, као и објективне критеријуме, издваја се функционалистички приступ култури. Теоретичари функционалистичке оријентације углавном нису много говорили о култури у смислу уметности, већ их је више занимала култура у смислу норми, вредности и начина живота.

Најпознатији и најзначајнији представник ове оријентације јесте Бронислав Малиновски. ${ }^{59}$ Он сматра како једна истинска теорија културе мора увидети да људско друштво има за подлогу биолошку чињеницу да су „људска бића једна животињска врста“. Дакле, човек је најпре морао биолошки да преживи и опстане, као сваки организам у природи, да би тек потом „човек створио једну секундарну средину“ - културу. ${ }^{60}$ Међутим, та секундарна средина, „сама култура“" коју је човек створио наспрам природне, као примарне средине, мора се „стално репродуковати, одржавати и усмеравати“. Свака „културна средина“ ствара свој културни „стандард живота“ као услов опстанка и напредовања заједнице, а на њему се увек изнова јављају нове „потребе“.

У темељу културе се према овом теоретичару налазе људске потребе, а други важан појам је концепт „функције“. Функција се може разумети као задовољење неке потребе активношћу у којој људска бића сарађују, употребљавају рукотворине и троше добра. Теоријска анализа којом се

59 Малиновски се сматра једним од утемељивача функционализма у антропологији и друштвеним наукама, а функционализам је био један од главних видова његовог приступа људском понашању.

${ }^{60}$ Б. Малиновски, Научна теорија културе, „Вук Караџић“, Београд, 1970, стр. 82. 
покушава дефинисати однос између културне радње и неке људске потребе, основне или изведене, може се назвати функционалном. ${ }^{61}$

Све је, дакле, функционално повезано са неком коришћу за човека. Целокупно културно понашање одвија се унутар „људске организације“. Трећи важан појам опстанка „културе“ и човека као духовног бића јесте традиција. Културна традиција се преноси с поколења на поколење уз помоћ механизама васпитне природе. Као четврти значајан појам културе појављује се њена организација унутар „институције“. Институција подразумева, према Малиновском, сагласност људи у погледу количине традиционалних вредности ради којих се они удружују и организују. Бронислав Малиновски, иначе, одређује културу на следећи начин:

„Култура је један интеграл састављен од делимично самосталних, делимично координираних институција. Она се интегрише на основу низа начела као ито су: заједница по крви, размножавање, просторна блискост, у вези са сарадњом, специјализачија активности, и на крају, али не и најмање важно, употреба моћи у политичкој организацији.“

Према томе, „култура је очито интегрална целина која се састоји од оруђа и потрошних добара, конституционалних статута разних друштвених скупина, од људских идеја и вештина, веровања и обичаја“. Било да разматрамо веома једноставну или примитивну културу, или пак крајње сложену и развијену, према Малиновском, увек имамо посла са огромним апаратом делом материјалним, делом људским, а делом духовним, захваљујући којем је човек у стању да успешно решава специфичне проблеме с којима се суочава. ${ }^{62}$

${ }^{61}$ На пример: потреба да се у слободном времену човек духовно уздиже и на посебан начин разоноди може се задовољити гледањем позоришне представе, а за ту прилику је настала институција позоришта. Као институција културе, она обавља функцију задовољавања једне битне културне потребе. Одржавање реда унутар друштва јесте потреба стара колико и људски род, а иста таква потреба је у институционалном смислу условила настанак и развој полиције.

${ }^{62}$ Б. Малиновски: Научна теорија културе, „Вук Караџић“, Београд, 1970, стр. 41. 
Култура је, дакле, значајан и сложен инструмент који треба да омогући човеку да овлада својом природном средином, стави је у службу својих потреба и тако осигура опстанак, репродукцију и продужење своје биолошке врсте. Коначно, културу је и неопходно схватити као средство за постизање одређеног циља, инструментално или функционално.

На друштвеном плану култура пре свега доприноси организовању људских бића у „трајне групе“ или пак организује или установљава такве групе као нове. Њихова правила, или „статут“ једне институције, дефинишу се као систем вредности зарад чијег се остваривања људска бића организују или улазе у већ постојеће организације. Особље једне институције дефинише се као група организована на темељу одређених начела ауторитета, поделе функција и расподеле повластица и дужности. Најзад, Малиновски показује да људи као културна бића живе у складу са нормама, обичајима, традицијама и правилима који су плод „узајамног дејства органских процеса и човековог манипулисања средином и њеног преуређивања““.

Код Боаса - свака култура има посебну историју, и стога је јединствена. Ако је човек у основи производ културе, свако ће друштво испољити неки другачији тип личности. За Малиновског су, међутим, сви људи у основи слични - када се истраже унутрашње динамике у оквиру група примитивних народа, откривају се исти чиниоци који покрећу и западног пословног човека или студента универзитета.

\subsection{5 Структурализам}

Структурализам је утицајан приступ истраживању културе, који је проистекао из лингвистичких теорија. У структуралистичким приступима се језик сматра кључем за разумевањем друштвеног света. За структуралисте је свет налик на језички феномен, јер се већи део друштвеног живота одвија путем језика, који га, према структуралистичком гледишту, и обликује. Управо су покушаји неких теоретичара да разоткрију темељну структуру знакова и језика утицали на развој структурализма. Структурализам анализира темељне структуре које 
су део човековог мишљења и људских друштвених група. Структура се при томе схвата као синхроно делатни систем релација, на којем се заснива повезаност одређеног искуственог система и који је погодан за поређење културних система.

Антрополог Клод Леви-Строс [Claude Lévi-Strauss] први је развио структурализам и применио га за разумевање, између осталог, система сродства и митова. Овај теоретичар сматра да свако људско мишљење и сви облици друштвености имају одређену структуру. Те структуре не можемо непосредно посматрати, али се могу разоткрити у човековој култури, коју те структуре обликују. Пошто су структуре заједничке свим људима, докази о њима могу се пронаћи свуда. Тако, митови древних Грка и северноамеричких Индијанаца (или америчких урођеника) одражавају исте структуре. Слично томе, сви системи сродства темеље се на истим основним структурама. Различити се митови или системи сродства могу у појединостима врло разликовати, но, основна структура је иста. Леви-Строс тврди да су феномени сродства исте врсте као и језички феномени. ${ }^{63}$

Према њему, сви родбински системи имају скупове односа и, попут језика, сваки део тог система има значење једино у односу према другим елементима. Тако, на пример, положај жене се може разумети једино ако се стави у однос с положајем мушкарца, а положај мајке се може појавити искључиво у односу према положају сина или кћери.

„Понављање образаца сродства, брачних правила, слична прописана стајалишта између одређених типова сродника и тако даље у различитим деловима света и у битно различитим друштвима наводе нас на то да закључимо како, у случају сродства, ... феномени које можемо посматрати проистичу из деловања закона који су општи, али имплицитни. “64

За Леви-Строса системи сродства нису једини универзални аспекти културе. Наиме, он тврди како је уочио неке бинарне опозиције, или парове

\footnotetext{
${ }^{63}$ Lévi-Strauss, Claude, The Structural Study of Myth, Suffolk: Basic Books,1963.

${ }^{64}$ Исто, стр. 34.
} 
супротности, које структурирају свеколико људско мишљење. Примери тих бинарних опозиција јесу природа-култура, мушкарац-жена, добро-зло. Категорије у свакој бинарној опозицији међусобно се искључују, нешто не може истовремено бити део и природе и културе. Међутим, бинарне опозиције понекад проузрокују противречности. Да би се та противречност разрешила, користе се митови. Овде се може поменути и значај бинарне опозиције између Оријента и Запада у западној мисли, на коју је указао Едвард Саид у свом делу Oријентализам [Orientalism, 1978], описујући је терминима који свакако нагињу онима које је користио Леви-Строс - тврдећи да разлику између „њих“ и „нас“ потхрањују академски специјалисти, односно професионални оријенталисти, који би заправо требало да је демонтирају. ${ }^{65}$

Неки теоретичари се не слажу са тврдњом Леви-Строса да људи увек мисле у бинарним опозицијама, као што је, на пример, у опозицији природе и културе. Сва друштва морају одговорити на постојање природе, али је не морају доживљавати као супротност култури. Наиме, различита друштва разумеју природу на различите начине, она нема исто значење за свакога и не посматра се увек као супротност култури. Људи у многим околностима размишљају истанчаније, а не у паровима супротности. Није све црно или бело, постоји још читав спектар боја између крајности.

${ }^{65}$ Саид је такође тврдио да је од XVIII века оријентализам, било манифестни или латентни, био повезан са колонијализмом и постао ,западни начин доминације, реструктурисања и владања Оријентом“. У Оријентализму су анализиране различите схеме којима су путници, романописци, интелектуалци са Запада описивали Блиски исток, стереотипима као што су „заосталост“, „пасивност“, „дегенерација“, „деспотизам“, „фатализам“ и „сензуалност“. Може се рећи да је књига пуна беса, страсна молба странцима да културе Блиског истока посматрају неспутани одбојношћу и снисходљивошћу. Ова студија је инспирисала многе сличне студије, не само о Азији, Африци и Северној или Јужној Америци, већ и о Европи. За наше просторе (простор Балкана) занимљиво је прочитати Имагинарни Балкан Марије Тодорове, преведен у оквиру издавачке куће XX век, 2006. године, и већ поменути Оријентализам, Едварда Саида у истом издању 2008. 


\subsection{6 Конструктивизам}

Конструктивизам је један од савремених теоријских приступа, који заузима значајно место у друштвеним наукама. Укључује сагле́дање начина на који су друштвене појаве креиране, институционализоване и постале део традиције. Уз конструктивизам често иде и атрибут „социјални“, јер полази од претпоставке да су сви човекови „производи“ социјално условљени, па тако и култура, наука, ставови, знања. Такође, друштвене појаве су, саме по себи, условљене историјским и социјалним околностима, а могу се спознати једино тако што ће их појединац конструисати у интеракцији са социјалним окружењем.

Конструктивизам се као теоријски правац устоличио почетком XX века, али конструктивистичке идеје нису нове, већ су зачете у различитим епохама људске мисли. На почетку XX века имао је двојаку примену; као ознаку за авангардни покрет оријентисан ка техници и као назив сазнајнопсихолошке теорије у оквиру наука о комуникацији. ${ }^{66}$ Конструктивизам сазнајнопсихолошке оријентације радикализује схватање Имануела Канта по којем је стварност увек одређена субјективним искуством.

Такав конструктивизам, који се назива и радикалним, не ослања се само на филозофију него и на сазнања биологије, неуропсихологије и кибернетике. Временом је овај теоријски правац стекао уплив и у друге научне дисциплине. Културни историчари, заједно са социолозима, антрополозима и осталим научницима, прикључили су се дебати коју су некада сматрали чисто филозофском или научном.

Конструктивизам је прича о утицају процеса сазнавања на уобличавање мишљења о људској природи. Полазећи од става да људи немају непосредан приступ стварности, већ да увек конструишу сопствене верзије те стварности унутар доступних референтних оквира, конструктивисти истичу да је „истина“ појам који у друштвеним наукама треба опрезно користити. Овај теоријски

66 Лексикон савремене културе. Теме и теорије, облици и институције од 1945. до данас, приредио Ралф Шнел, Библиотека Посебна издања, Плато Books, Београд, 2008. 
правац проблематизује „очигледно“, „стварно“, „разумљиво са́мо по себи“. Доводи у питање становиште да је конвенционално знање утемељено на објективним, дакле непристрасним запажањима и да можемо лако разликовати субјект од објекта, перципирано̄ и стварно̄.

Представници конструктивизма упозоравају да је потребна сумња према нашим претпоставкама о томе како свет изгледа и о категоријама које користимо да бисмо га разумели и интерпретирали. Такве категорије и концепти морају се сагледати као променљиве - дакле, историјске и културне специфичности које се због тога разликују у различитим раздобљима и на различитим местима. Управо због тога и долази до заокрета ка конструктивизму у другој половини XX века.

Успон „историје одоздо“, као у Настајању енглеске радничке класе Едварда Томпсона, укључивао је и покушај да се прошлост представи из угла обичних људи. Слично је било и са историјом колонизованих земаља у Азији, Африци и Америци, која се појавила истовремено с постколонијалним студијама и често се усмеравала на „поглед покорених“ или гледиште „потлачених класа“.67 Слично томе, феминистички теоретичари су покушали да жене учине „видљивијима“ у многим друштвеним процесима и да их проучавају на основу виђења из женског угла. Историчари су били међу првима који су постали свесни да различити људи могу сагледати „исти“ догађај или структуру из веома различитих углова.

У терминологији конструктивизма често се користи термин значење, а за појединца се каже да конструише значење неке социјалне ситуације. Разумевањем значења, дакле онога што појединац мисли о појавама око себе и начина на који их тумачи, може се сазнати много и о ономе чије су мисли и значења. Идеју о „значењу“ је у антропологију крајем 1950-их година увео Клифорд Герц и представио је као „скуп културно конструисаних и историјски специфичних упутстава, оквира или модела осећања, намера и делања““, као и

\footnotetext{
${ }^{67}$ Питер Берк, Основи културне историје, Клио, Београд, 2010, стр. 98-99.
} 
модела за њих. Једноставније речено, значење истовремено дефинише живот и даје му сврху. ${ }^{68}$

Конструктивисти верују како човек, да би разумео овај свет значења, мора да га интерпретира, а интерпретативна културална анализа довела је у питање схватање друштва као машине или организма, по којем се сложене интенције људских бића и културне формације своде на допринос функционисању друштвеног строја-организма.

Макс Вебер је својевремено описао човека као „животињу заплетену у мреже значења које је са̂м исплео“, а томе се онда може додати да културу чине управо те мреже. Клифорд Герц сматра да је анализа културе једна интерпретативна наука у потрази за значењем, а не експериментална наука у потрази за законом. Свој „интерпретативни, хуманистички приступ“ Герц је формулисао у противставу према облицима објективизма и редукционизма који су доминирали половином прошлог века у антропологији и другим друштвеним наукама. Његов теоријски допринос проучавању културе поједини аутори су видели на различите начине.

Издвајамо, пре свега, наглашавање културне разноврсности симболичких форми и људског понашања, као и критику свих видова редукционизма. Затим, епистемолошки допринос се огледа у увођењу херменеутике и феноменологије, херменеутичког круга и дескриптивне феноменологије у етнографску праксу (наративност, рефлексивност и тумачење). Филозофски допринос се састоји у критици научног позитивизма и наивног емпиризма, као и у одбрани хуманистичког холизма.

Герц је на више начина покушао да дефинише и објасни суштину културе. По њему, култура је: „артикулисана укупност уређених гроздова значењских симбола“, „уређен систем значења и симбола ... помоћу којих појединци дефинишу свој свет, изражавају емоције и стварају процене“, „историјски преношен образац значења отеловљених у симболима, систем наслеђених

${ }^{68}$ Гордана Горуновић: Антропологија Клифорда Гериа-Културна теорија и интерпретативна анализа култура, Филозофски факултет Универзитета у Београду, Београд, 2010, стр. 226227 
појмова изражених симболичким формама уз помоћ којих људи преносе, чувају и развијају своје знање о животу и ставове према њему“, као и „скуп симболичких средстава за регулисање понашања, екстрасоматских [вантелесних] извора информација“. 69

Он се определио за семиотичко схватање културе и интерпретативни приступ њеном проучавању. Герц сматра да је анализа културе „интринсично непотпуна“, да је то „чудна наука“ чије најупечатљивије тврдње имају најнесигурнију основу и у којој напредовати у вези са неким питањем значи појачавати сумњу, и у себи и у другима, да га нисте баш добро схватили. ${ }^{70}$

Анализа културе је, као што видимо и након овог приступа, веома комплексна и увек постоји опасност да потрага за њеним дубљим слојевима изгуби додир са „тврдим“ димензијама живота - са политичким, економским, стратификаторним реалностима којима су људи окружени - и с биолошким и физичким потребама на које се те димензије ослањају. Све је, у ствари, као и увек, много сложеније.

\subsection{7 Студије културе}

Студије културе припадају теоријској оријентацији која се отворено залаже за идеју да је културу могуће наћи свуда и на свакоме месту, те да је сваки напор да се она ограничи и учврсти у свом појму - не само непотребан већ и немогућ. Прва особеност ових студија огледа се управо у томе да се култура посматра као динамична, хетерогена, променљива и ставу да она не постоји као изолована област, независна у односу на динамику друштвеног, психолошког, економског, политичког, емоционалног и имагинарног/духовног живота људи.

\footnotetext{
${ }^{69}$ Клифорд Герц, Тумачење култура 1, Библиотека ХХ век, Београд, 1998.

${ }^{70}$ Наравно, увек постоји начин да се побегне од оваквог приступа, што значи да се култура претвори у фолклор и почне се бавити прикупљањем података о њему, претвори у обележја и пребројава их, претвори у институције и класификује их, претвори их у структуре и игра се са њима. Исто, стр. 44-45.
} 
Према овим размишљањима култура није везана само за највише домете духа, већ она обележава и свакодневни живот обичних људи, исказује се у једноставним животним стварима, осећањима, укусима, навикама и веровањима, који чине специфично културно искуство различитих друштвених група. Ове и сличне идеје студија културе проистекле су из радова Рејмонда Вилијамса [Raymond Williams], Ричарда Хогарта [Richard Hoggart] и Едварда Томпсона [Edward Palmer Thompson], интелектуалаца радничког порекла, који су привржени, пре свега, марксизму и социјалистичкој левици у Великој Британији.

Студије културе представљају једну хетерогену област која не може да се подведе под одређене дисциплинарне оквире, јер на различите начине спајају искуства антропологије, филозофије, лингвистике, баштину књижевне критике, политикологије, психологије. У том мноштву дисциплина, студије културе не користе ниједан одређен метод традиционалних дисциплина већ узимају оно што омогућава да се култура разуме као вишезначан, сложен и динамичан феномен. $^{71}$

Студије културе дуго нису биле прихваћене као посебна дисциплина и као легитимна академска област. Настале су насупрот званичном поретку академске средине Велике Британије, крајем педесетих година XX века. ${ }^{72}$ Биле су један од видова алтернативног мишљења, укључене у алтернативне културне и социјалне покрете који су мењали дотадашњи поредак западног света и извршили снажан утицај на готово све сфере друштвеног живота. Међутим, студије културе, ослањајући се, с једне стране, на сасвим одређене, у основи постмодернистичке теоријске правце, а, с друге стране, са отвореним

71 Студије културе су препознатљиве у свету науке и шире, а често се називају „трансдисциплином“ или „недисциплинованом дисциплином“, која спаја различите методологије и теме традиционалних дисциплина, у складу са захтевима динамичних животних промена савременог света.

72 Свој институционални живот студије културе су започеле у Центру за савремене студије у Бирмингему, а затим се њихов утицај ширио и на подручје САД, Канаде и Аустралије, неке бивше британске колоније (Индија), а временом се њихов утицај осетио и у Јужној Америци и земљама бившег социјалистичког блока. 
идеолошким и политичким потенцијалом, укидају идеју универзалног значења и значаја културе указујући на релативност и временско-просторну променљивост културе. Уместо објективног знања о култури, пласира се идеја о њеном субјективном значењу, о смислу што га она има за људе који уобличавају властита искуства дајући значење стварима и процесима који их окружују. $^{73}$

Проблеми вредности или естетског просуђивања квалитета културних производа нису у фокусу интересовања студија културе, већ савремени живот, популарна и медијска култура, појаве кратког трајања и слични феномени. У оквиру студија културе, култура се зато често представља као синоним за друштво (што није новина), али исто тако ове студије показују незаинтересованост за оно што се најчешће сматра културом: за уметност, религију, филозофију и народне обичаје. На тај начин култура престаје да буде начин самоостварења духа, простор умности и општечовечанског кретања заснованог на смислу или трагању за њим, већ обележава и свакодневни живот обичних људи, оличен у њиховим осећањима, укусима, навикама и веровањима који чине специфично културно искуство различитих друштвених група.

На представљање различитих приступа изучавању и тумачењу културе и њених феномена овде бисмо ставили тачку. Неки значајни теоретичари културе представљени су како би се на њиховом раду показали правац и тенденције читаве школе мишљења у датом тренутку. При том, нису детаљно набрајана различита становишта унутар појединачних теоријских праваца, већ само она која су погодни представници за илустрацију општег принципа. Усредсређеност на одређене представнике или теоријске правце може произвести проблем, посебно ако се зна да су неки од ових праваца изгубили оштрину, да су им откривене многе мане или да се нису развијали даље од почетне идеје.

73 Јелена Ђорђевић, предговор, у: Сmудије културе, Зборник, приредила Јелена Ђорђевић, Службени гласник, Београд, 2009, стр. 12-13. 
На основу изложених различитих теоријских приступа и научног објашњења културе и неких културних феномена који су њен саставни део, на крају овог дела могу се издвојити кључни елементи и домени који ће послужити разради концепта безбедносне културе. На неке од њих ћемо се враћати и позивати даље у тексту, када се за то укаже потреба. То су следећи домени:

- Култура је услов, средство и суштина људске егзистенщије. Она има потенцијал да утврди начин усмеравања и улагања у продужење живота и обезбеђивање његовог смисла.

- Култивисање, или обрађивање, израз је основне везе између људских група и природне околине од које добијају средства за живот. Тиме култура означава основне начине на која различита друштва виде своју повезаност са природом не само као извор хране и енергије, него и као извор искуства које би им помогло да се носе са смртношћу, опасностима и ризицима којима су изложени и да обележе значајне прекретнице у циклусу људског живота.

- Култура је фактор који игра значајну улогу у моделовању људског понашаља, а то нису само „природни инстинкти“, што се као тема често појављује у дискусијама о еволуцији заједница, од племена, преко царстава до модерних држава. Негде су овакве заједнице моделоване утицајем окружења, климе и присуства конкурентне заједнице, а негде идејама које су људи имали о томе ко су и који су им заједнички циљеви који их везују у заједницу.

- Култура се може и мора узети у разматрање као један од значајнијих фактора који одређује или утиче на укупан друштвени развој, политички, економски, технолошки, али и развој у области безбедности и безбедносних појава и феномена.

- Да би се на адекватан и применљив начин прихватио концепт културе као одредиште бројних и све актуелнијих размишљања у области безбедности 
и безбедносних појава, неопходно је помирити субјективну идеју са објективном/појавном стварношћу. ${ }^{74}$

- Култура је у својој суштини једно корисно средство (оруђе) помоћу којег је човек стављен у положај да се успешније бори са конкретним специфичним проблемима с којима се сусреће у својој околини у процесу подмиривања сопствених потреба.

- Култура се може представити и као међусобно испреплетени системи знакова (симбола) подложних тумачењу, али она није моћ, нешто чему се друштвени догађаји, понашања, институције или процеси могу каузално приписивати; већ је контекст, нешто унутар чега се они могу појмљиво, тј. подробно описати.

- Култура је теоријска и практична област која се изнова проблематизује, добија нова значења и тумачења и све се више везује за конщепте који представљају важно аналитичко оруђе за разумевање многоструких промена у савременим друштвима.

\subsection{8 Хуманолошки поглед на културу}

\section{као теоријска перспектива}

\subsubsection{1 Теоријска исходишта развијања интереса безбедности}

На основу представљања више теоријских оквира за тумачење и смислено објашњење концепта културе, као и издвајања најбитнијих одлика које ће нам послужити у даљем уобличавању концепта безбедносне културе, неопходно је

\footnotetext{
${ }^{74}$ Поређењем објективних и субјективних нивоа безбедности може се показати да постоји значајан несклад у погледу онога за шта се сматра да је остварено на плану објективне безбедности и онога што је субјективна перцепција нечије безбедности. Постојање разлика између објективних услова и субјективних перцепција указује на размимоилажење између система и појединца, што може да доведе до друштвених конфликата. Избор субјективних показатеља безбедности и субјективна перцепција условљени су културним факторима, наслеђем, традицијом и сличним чиниоцима.
} 
утврдити или бар претпоставити која су то теоријска исходишта развијања потребе и интереса безбедности, а која ће прибавити или омогућити управо култура. Да бисмо то постигли, увешћемо један другачији поглед на културу, чија хуманистичка основа треба да буде претпоставка и циљ људског деловања, која ће у исту раван довести људску природу и људску стварност.

Изучавање стварности претпоставља приписивање људског значења њеном садржају, при чему се утврђивање узрочности и правилности међу појавама поставља као средство сазнања. Специфичност феномена људског искуства нагласиће се управо преко категорије „духовног“, на шта су својевремено указивали Дилтај и Вебер у настојањима да конституишу хуманолошко утемељење научног знања о човеку, његовој природи и његовој стварности. ${ }^{75}$

Можемо кренути од става да је култура свеукупност промена у природи, друштву, мишљењу човека, чији је циљ одржавање људске врсте на Земљи и њен развој. И етимолошки посматрано, као што смо видели, култура означава човекову повезаност са природом. Кроз функције опстанка и заштите помогла је првобитном човеку да преживи у свету дивљих животиња и елементарних непогода. Такође, кроз дуг временски период, под утицајем разноврсних околности, култура је заправо помогла човеку да из природног пређе у друштвено стање и довела је до његових значајних промена. Тим преласком човеково понашање више није вођено инстинктом, већ правдом, а поступцима је додата моралност - физички нагон је, дакле, замењен гласом дужности, а прохтеви правом.

Култура је, може се рећи, учинила да човекова природна својства добију једну потпуно нову димензију и преобликују се у друштвени живот који има своја правила, своје обрасце који препоручују одређено пожељно понашање и своје оквире деловања, условљене суштинским својствима која одвајају једну друштвену групу од друге.

Захваљујући култури, човек је стекао бројна преимућства, вежбао и развијао своје способности, проширио своје идеје, његова су се осећања оплеменила и,

\footnotetext{
${ }^{75}$ Миленко Бодин, „Хуманологија и хуманолошке науке“, Зборник радова, Факултет цивилне одбране Универзитета у Београду, 2002, стр. 369-383.
} 
једном речју, постао је разумно биће и човек. Заправо, речено на начин на који је Маркузе дефинисао културу, она је била процес хуманизащије који карактерише колективни напор да се заштити људски живот, смири борба за егзистенщију ... да се стабилизује производна организащија друштва, да се развију интелектуалне способности човека, да се умање и превладају агресија, насиље и беда. ${ }^{76}$

Када је „превазиђена“ фаза опстанка (елементарног људског живота) и када су се појавили први елементи друштвености, почели изграђивати друштвена структура и у оквиру ње друштвени односи, то је и улога културе померена ка опстанку и заштити специфичног/особеног начина живота који су поједине људске скупине почеле да развијају. Наиме, појава својине је изазвала и одређене противречности, које су у још увек крхком првобитном људском друштву изазвале конфликте и створиле нове „непријатеље“ као кључне факторе угрожавања човека као појединца или дела друштвене групе. Са становишта појединих група људи и њихових посебних обележја (данас, рецимо, нације и њихове националне културе), који живе на одређеном простору, одржавање људског живота као основни циљ културе, не може да се прошири на све људске животе, дакле и оне из других група.

Оваквим изношењем чињеница отварају се и одређена питања, као, на пример: Да ли се првобитно разумевање циља културе протеже само на тај људски живот који је дефинисан као вредан одржавања, пропагирања и уживања: оно што се дефинише као „наше“? Да ли се односи на све људе и све људске скупине? Претпоставимо да његово одржавање, простирање и уживање може да подразумева, између осталог, конкуренцију са другим групама људи за контролу ресурсаิ, укључујући и простор где живе. Тако се и појавила потреба или захтев за одвраћањем или укидањем облика људског живота који је дефинисан као „остало“, а тако се заправо и појавио или конституисао идентитет као специфично обележје једне групе људи у односу на другу.

Са развојем специфичне материјалне културе (начин произвођења оружја и оруђа, начин лова, градње првих насеобина итсл), као и духовне компоненте

\footnotetext{
${ }^{76}$ Херберт Маркузе, Култура и друштво, БИГЗ, Београд, 1977.
} 
(обреди, ритуали итд), долази до издвајања посебних група које развијају сопствене групне идентитете. Са циљем да се очувају идентитет и интегритет одређене групе, успостављају се и посебна правила понашања у облику наредби и забрана. Тако, на пример, употреба алата, хране, правила̂ лова само су неки од сегмената материјалне културе по којима је једна група почела да се разликује од друге. По логици бинарних опозиција, коришћење одређеног алата или активности добија смисао, постаје значајно једној или другој супротстављеној култури.

Обележја или маркери ${ }^{77}$ културног идентитета временом испољавају тенденцију да постану организовани у систем правила за понашање. Именовање појединих решења (за појединачне практичне проблеме), као маркера идентитета, доводи до описних генерализација: „Они који то раде на овај начин јесу ова врста људи.“ Употребљени као сопствени маркери идентитета, описују генерализације и уједно постају нормативи: „То је оно како ствари треба да се ураде.“ Следећи корак је био да се концептуализује разлика између „нашег“ начина да се нешто уради и начина оних „других“. Истовремено је оно „наше“ уједно и добро, а према оном „другом“ смо равнодушни, или је означено као лоше.

Управо преко маркера̂ културног идентитета људи су почели да долазе у сукобе, било да су желели да наметну свој начин живота (своја решења проблема), своја обележја, било да их сачувају од наметања других или да једноставно сачувају ресурсе како би преживели као посебна скупина. У том смислу се култура и културни идентитет представљају као фактори који су доводили до бројних сукоба вођених током читаве историје људског друштва, па је тако и данас.

Нас даље занима како се на основу формираног идентитета једне људске скупине (у једном тренутку је то постала нација) изнедрио интерес за безбедношћу и каква је улога културе у томе, ослањајући се овог пута на њене позитивне аспекте и домене. Да бисмо то објаснили, потребно је увести у теоријску анализу једну нову величину, а то је слобода. Слобода је човеково

\footnotetext{
${ }^{77}$ Маркери културног идентитета су: морал, језик, етницитет, територија и слична обележја.
} 
елементарно искуство и основно природно својство, без којег се нису могли развити ни право, ни дужност, ни моралност. Уједно иде у пару са безбедношћу, јер, између осталог, условљавају једно друго, тражећи прихватљив баланс. ${ }^{78}$

Једно је виђење слободе која је садржана у природи човековог постојања, дакле као његово природно својство, а друго је разумевање слободе која је дело културе, колективног живота, права. У оба случаја реч је о могућности избора: у првом - на делу су наши духовни услови избора и стварања, али и сама чињеница да смо у стању да бирамо и стварамо, у другом случају - реч је о ситуационим условима избора, односно то шта нам друштвена организација и право уопште остављају да бирамо.

Апсолутна слобода, која је према Томасу Хобсу представљала основну карактеристику природног стања, ${ }^{79}$ у којем нема никаквог закона, правила или организације колективног живота, већ постоји само непрестана борба „свих против свих“, водила је међусобном неповерењу. Пошто је такво стање било неподношљиво, људи су се договорили да се удруже у одређене заједнице којима управља централна власт и које ће омогућити безбедан друштвени живот. Зарад сопствене безбедности и успостављања мира, људи се одричу дела своје слободе, који преносе на суверена. ${ }^{80}$ На сличан начин Џон Лок говори о „савршеној слободи“ и „стању једнакости“ у којем се људи

${ }^{78}$ Слобода омогућава да се раде ствари које се воле и да се чува друштво које се креће напред. Слобода, иначе, покреће свет. Иако нису сви људи широм света слободни, сваки дан се предузимају одређени кораци којима се креће ка слободном свету. Безбедност је потребна, јер безбедност и слобода не могу постојати једна без друге. Када слобода почне да прекорачује своје границе, безбедност је ту да стави вето.

79 Хипотетичко „природно стање“, које су теоретичари друштвеног живота некада исцрпно разматрали, заправо, према мишљењу других теоретичара, уопште није ни постојало, а и да јесте, не би било стање неограничене слободе. У таквом свету није „све допуштено“, јер нешто може бити дозвољено или не само на основу одређеног права. Где нема права, нема ни слободе, па је самим тим слобода увек ограничена.

${ }^{80}$ Томас Хобс, Левијатан, Култура, Београд, 1961. 
усаглашавају и удружују како би живели безбедно и у миру у односу на оне који их нападају и живе у другој заједници.

Слобода, као природно својство човека, представља темељну вредност која је проистекла из „природног стања“ и коју прати безбедност и интерес безбедности као антрополошко својство човека и као регулативни инструмент у форми друштвеног живота. Управо је та регулативност, као основ остваривања интереса безбедности, део хуманолошке перспективе тумачења културе, која ће означити и то на који ће се начин и којим средствима остварити регулативна функција уређености. ${ }^{81}$

Познато је да одувек постоји тежња да се успостави равнотежа између безбедности и заштите основних права и слобода појединца, као и интереса друштва и заједнице. Ни у једном друштву не могу се остварити максимална безбедност, као ни апсолутна слобода, тако да се оба појма морају прихватити као варијабилне величине с обзиром на дивергентне, конфликтне и непомирљиве интересе појединаца и група у сваком друштву. Безбедност се мора ставити на своје место пре него што слобода буде заиста слобода. Па тако слобода и безбедност морају да постоје и опстају заједно како би се одржао човек као појединац и човечанство као људска заједница на максимуму својих способности и могућности.

Безбедност не сме дозволити да се слобода дегенерише у анархију, већ заједно морају бити у савршеној хармонији. Ако се слобода замењује безбедношћу, и обратно, систем постаје неуравнотежен и распада се. ${ }^{82}$ Тако се може рећи и да је без слободе - безбедност ропство, а без безбедности - слобода је илузија.

81 Више о хуманолошком моделу конципирања интереса безбедности видети у: Миленко Бодин, „Теоријске претпоставке разумевања и остваривања националне безбедности“, у: Ризик, моћ, заштита - Увођење у науке безбедности, Службени гласник и Факултет безбедности, Београд, 2010, стр. 135-150; и од истог аутора: „Хуманологија и хуманолошке науке“, Зборник радова, Факултет цивилне одбране Универзитета у Београду, 2002, стр. $369-381$.

${ }^{82}$ Слобода се мора схватити у границама односа према другим појединцима, чији интегритет и достојанство не смеју бити повређени човековим деловањем и тада „слободни избор“ има 
Култура је арбитар или управљач, дакле онај елемент или полуга у друштвеним односима и друштвеној структури који је омогућио да се развије и онај други простор мисли у оквиру којег се разматра слобода као део културе, колективног живота и права. Слобода је у том значењу простор људске активности, у којем друштвена организација ништа не забрањује нити налаже, у којем људи могу бирати шта хоће, чинити нешто или не чинити, без излагања репресијама. ${ }^{83}$ Слобода је у том значењу и ступњевита, има је више или мање, а постоји и навика да се различита политичка уређења мере аршинима слободе од таквих где је слобода близу нуле (тоталитарни режими у својим најекстремнијим видовима), до таквих где су забране и наредбе сведене на минимум.

У сваком случају, да би се остварио интерес безбедности и да би се утврдио начин одвијања те активности, мора се утврдити специфичност начина живота који је у основи једне културе и који „производи“ одређени ниво слободе и безбедности који су неопходни да се такав живот одржи. Национална култура у том смислу може да представља оквир стваралаштва и деловања једне националне заједнице, затим оквир култивисања нације и релевантни оквир у којем се проналазе и производе средства за решавање проблема (видети схему број 1).

другачије значење од импулсивног, ирационалног деловања, из којег проистичу неморални поступци.

83 Лешек Колаковски, Мини предавања о макси стварима, Плато, Београд, 2001, стр. 61-62. 


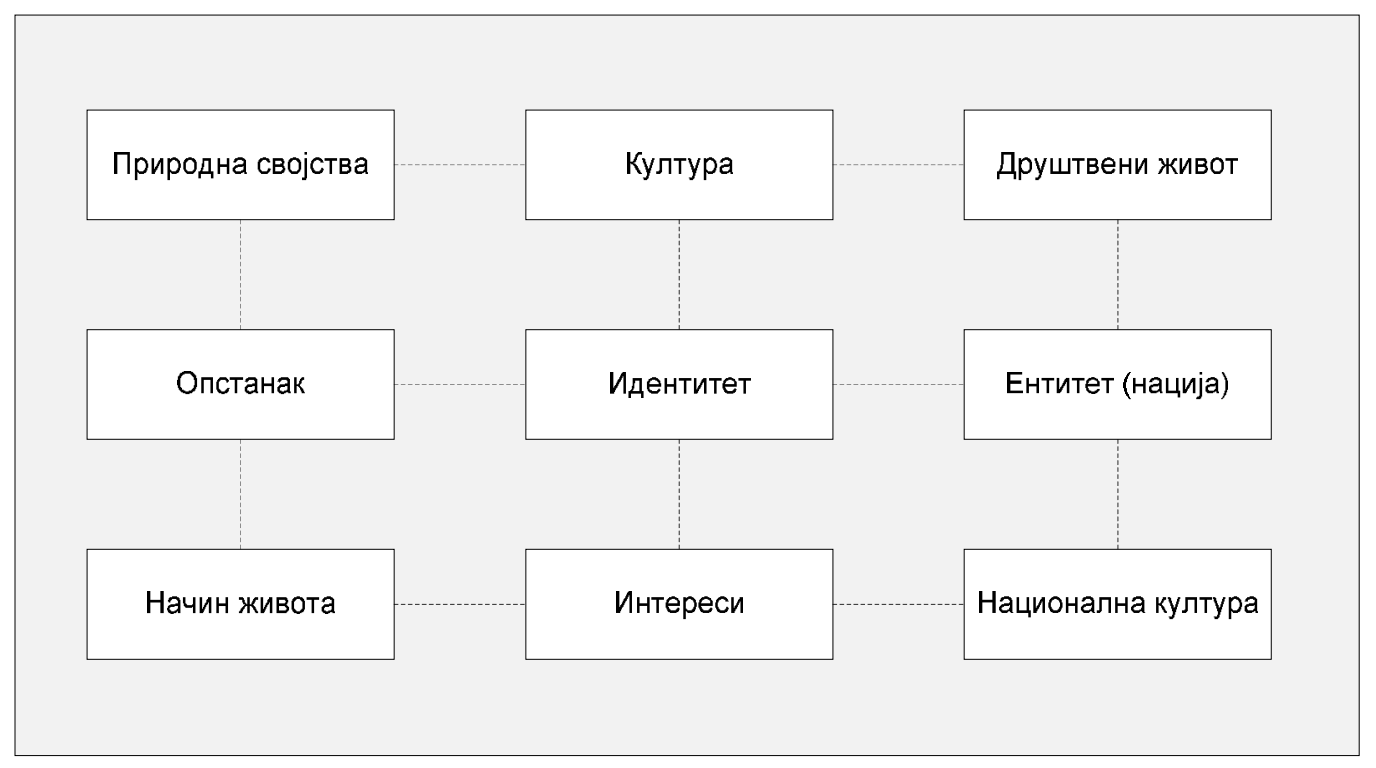

\section{Схема 1. Хуманолошко разумевање културе}

Самим тим, национална култура значајно опредељује разумевање света, као и понашање у њему, али исто тако представља не само услов опстанка већ и услов развоја, добробити и одрживости. Дакле, култура је прешла дуг пут, од тога да је била само услов опстанка, до тога да је постала услов развоја и напретка савременог друштва, а на том путу развија интерес безбедности, као један од суштинских интереса који покреће савременог човека.

Хуманолошка перспектива тумачења културе, између осталог, подразумева оно својство културе које ће развијати и подржавати проактивну људску природу (генеричку конституцију) и њене могућности, како човек не би био заробљен (сопственом природом), већ да би активним радом достигао цивилизовани друштвени живот, у којем царују безбедност, слобода, добробит и развој.

\section{2 Култура између идентитета и разлике}

Од тренутка када су многи критичари почели указивати на немогућност постојања хомогеног концепта културе и откривали специфичне језике и значења многих поткултура, све више је у жижу интересовања долазио 
субјективни доживљај културе, било да је реч о појединцима или групама. Управо кроз појам идентитета, који је у савременом свету разломљен и испресецан по различитим осама припадности, преламају се и све остале линије културе. Проблем идентитета је првобитно био везан за политике идентитета, којима су се промовисали културе и групни идентитети маргиналних и маргинализованих група, а затим се скренуо поглед на различитост и, пре свега, пра́во на разлику.

Културе се разликују по томе што се извесна одлика или особеност налази у једној култури, а у другој не, или по томе што се одређена одлика јавља у двема областима и у два различита облика. Такође, разлика може бити и у томе што су као целине усмерене у различитим правцима. Оне се крећу различитим путевима ради постизања различитих циљева, а ти циљеви и та средства у једном друштву не могу се оцењивати мерилима неког другог друштва, зато што у суштини немају међу собом много тога заједничког. ${ }^{84}$ Мерила се, без обзира на то који је вид понашања у питању, крећу у разним културама од позитивног до негативног пола. Можемо се сложити у претпоставци да су сви народи сагласни у осуди одузимања живота другоме.

Супротно томе, када је у питању убиство, у неким културама може се сматрати да је човек невин ако су међу двема земљама прекинути дипломатски односи, или ако је човек сагласно обичају убио своје прво двоје деце, или ако муж има право над животом и смрћу своје жене, или ако је дужност детета да убије своје родитеље пре него што остаре.

Код неких народа човек се подвргава мучењу зато што је случајно проузроковао нечију смрт; код других нехотично убиство не повлачи никакве последице. Самоубиство исто тако може бити сматрано за ствар која не заслужује нарочиту пажњу, уточиште ономе ко је претрпео неко омаловажавање, или најузвишенији и најплеменитији поступак који је један мудар човек у стању да предузме. С друге стране, и са́мо помињање самоубиства може бити ствар која се прима с неверицом и смехом, а да је са̂м

\footnotetext{
${ }^{84}$ Рут Бенедикт, Обрасизи културе, Просвета, Београд, 1976.
} 
чин несхватљив као људски могућ. Оно може бити и законски кажњиво кривично дело или се сматрати као „огрешење“ о богове.

Рат у западној цивилизацији, и поред тога што је кроз историју заузимао значајно место, представља противдруштвену чињеницу. У збрци која је настала након Првог, па и Другог светског рата испоставило се да су сви разлози из ратног времена који су објашњавали његово подстицање храбрости, алтруизма, духовних вредности добили један лажан и непријатан одјек. Све ово пружа веома поучан пример за разорно дејство до којег може довести развитак једног одабраног културног обележја. Ако би се рат оправдавао, разлог томе је што сви народи увек оправдавају особине за које сматрају да их сами имају, а не зато што је рат у стању да издржи непристрасно оцењивање његових „добрих страна““.

C друге стране, једном народу може бити немогуће да уопште схвати могућност ратног стања. Рут Бенедикт наглашава да су прави пример за то Ескими. Еским сасвим добро може разумети могућност да човек може убити човека. Ако постоји особа која му смета, процени своју снагу и спремност, он ће га убити, при чему његова јачина утиче и на то да нема друштвене одмазде. Али Ескимима је потпуно страна идеја да једно ескимско село устане против другог у бојном поретку или једно племе против другог племена, или чак да се неко село одлучи на ратовање из заседе. Мисао о убиству може да се роди само у једној глави и не дели се, као код западног човека, у категорије - једну која заслужује сваку похвалу и другу која се сматра за најтежи злочин.

Не уобличавају све културе безбројне појединости свог понашања према једном уравнотеженом и ритмичном обрасцу. Попут извесних појединаца, одређени друштвени пореци не подвргавају своје поступке устаљеним и владајућим побудама. Наиме, они се осипају, мењају, прелазе из једног облика у други. Ако се у једном тренутку чини да иду за остваривањем одређених циљева, у другоме су се окренули у неком можда и супротном смеру, који не даје никакав путоказ за делатност која ће доћи после тога. Такав недостатак интеграције, или целовитости, одлика је одређених култура, као што је и крајња интеграција одлика неких других. Једна култура може попримити у себе 
многе одлике других култура из окружења, па, на пример, технологију и начин обраде одређених материјала може преузети из једног културног подручја, делове својих верских обичаја из другог, неке наредне елементе из трећег.

Технологија, културно прилагођавање, обреди зрелости (прелаза), начин ратовања или друштвена структура само су неке од особина које се у једној култури могу наглашавати и разрађивати, а у другој потпуно пренебрегнути. Тако, на пример, у једном друштву технологија може бити невероватно потцењена чак и у оним областима живота које се чине неопходнима за обезбеђивање опстанка; док су у другом, исто тако једноставном - технолошка достигнућа изванредно истанчано сложена и прилагођена приликама.

\subsection{1 Културни обрасци као фактори идентитета и разлике}

Културни образац је уопштен начин понашања карактеристичан за одређено друштво. Сврха таквог уопштавања је у покушају да се обухвати већи комплекс чињеница, да се оне смисаоно изразе и интерпретирају. Културни образац се може представити као „смисаони оквир оријентације и интеграције једне заједнице који обухвата, пре свега, вредносне системе помоћу којих појединци и друштвене групе долазе до разумевања себе и света у којем живе, као и моделе за акцију ради остваривања изабраних циљева и промовисања пожељног начина живота““ ${ }^{85}$

Многи истраживачи културне обрасце поистовећују са начином живота, истичући да је „начин живота или културни образац друштвено омеђено поље у којем се крећу појединачна свест и понашање“. Начин живота је

${ }^{85}$ Клифорд Герц је, говорећи о култури и изучавању са становишта „контролног механизма“, истакао да када човековим понашањем не би управљали културни обрасци - организовани системи значењских симбола - оно би практично било необуздано, чист хаос бесмислених поступака и експлозија емоција; његово искуство би практично било безоблично. Култура, акумулирани тоталитет таквих образаца, није само украс људске егзистенције већ - као главни основ њене специфичности - и њен суштински услов. Видети шире у његовом раду: Тумачење култура 1, Библиотека ХХ век, Београд, 1998, стр. 64. 
институционализован облик културног обрасца, као систем узајамно повезаних норми и вредности - у вези је са материјалним условима живота и разликама међу њима. Тако се културним обрасцима може назвати свака норма, одређени облик мишљења, деловања и понашања који се понавља и у оквиру којег се јављају и функционишу ствари, знаци и понашања. Друштво ствара одређене културне вредности, при чему један глобални друштвени систем може прихватити неке универзалне вредности и мноштво културних образаца, али може имати и неке специфичне вредности и обрасце понашања и разноврсне начине решења људских и друштвених проблема.

Како културни образац делује на појединца и обратно, покушала је да објасни Рут Бенедикт. Наиме, она сматра да већ створени културни образац делује на појединце својеврсном принудом. Међутим, има места за индивидуално стваралаштво, којим се појединац, добро прилагођен обрасцима своје културе, може појавити као њен даљи стваралац. „Највећи број људи се прилагођава облику своје културе због изванредно велике савитљивости њихових урођених склоности. У сваком случају, огромна већина појединаца прихвата без отпора онај облик који јој се пружа.“86

Разлог због којег култура има тако силну моћ над човеком Рут Бенедикт је пронашла у „емотивним основама културе“. „Појединац се емотивно везује толико снажно за своје обичаје и веровања да је за њега доиста немогућно да их доводи у питање, још мање да их оспорава. Чак и када им установе дају најширу слободу, људи никад нису довољно довитљиви да унесу нешто више од безначајних промена.“ Наиме, појединци могу „изабрати“ или бити присиљени да прихвате низ ситуација које не воде ка очовечењу њихових сопствених потенцијала, већ ка самоотуђењу, или ономе што је Фром назвао „бекство од слободе“. Као и Боас, Рут Бенедикт је сматрала да се стваралачка сила интеграције налази у уму појединца, да тај ум одабира и преиначује културне одлике деловањем појединца у складу са субјективним мерилима њихове културе.

\footnotetext{
${ }^{86}$ Рут Бенедикт, Обрасичи културе, Просвета, Београд, 1976.
} 
Заједнички обрасци понашања који су карактеристични за неку групу изражавају се различитим начинима на које друштвена заједница реагује на друге припаднике те исте групе и њихову физичку околину. Култура једног друштва састоји се делимично од одређеног низа поступака у решавању проблема̂ чланова друштва. Неки од тих проблема својствени су члановима датог друштва, други су универзални, заједнички свим људским бићима. Постоје, природно, различити начини решавања тих проблема. Све то доводи до сазнања да се може потврдити да не постоје две идентичне културе. ${ }^{87}$

Западна цивилизација, услед одређених историјских околности, распростире се на ширем пространству него иједна друга до сад позната „локална скупина“. Она је наметнула свој образац највећем делу Земљине кугле, па су људи у неким претходним временима били наведени да поверују у једнообразност људског понашања до које под другим околностима не би дошло. Изузетно је важно сагледати шта су одговарајући односи у неком времену значили за људе који су у њему живели, а не само шта они значе за човека данас, према савременим мерилима. Тако, на пример, приношење на жртву може да се доживи као израз признања, а не као друштвена неправда, како се то данас схвата. Ако се сопствена етичка и естетска мерила примене на стране културе или далека времена, као што неки научници несвесно чине, онда је немогуће разумети их.

Да бисмо описали и на неки начин оценили културу једног народа, морамо узети у обзир све гране његовог духовног живота, дакле његову науку, веру, морал, његову књижевност и уметност, али исто тако и његову политику и право, његову војску и привреду, његове обичаје и забаве. Тек анализом свих

\footnotetext{
87 За многе је током историје постојала само једна култура, а то је била грчко-римска. Неки морепловци су писали и о далеким земљама, али веома дуго на такав начин као да описују егзотичне животиње или биљке. Све је то било интересантно само као необичност, а не као и актуелни начин живота људи и народа, па су се мерила западног морала и естетике, једном речју западњачке надмености, стално мешала у оцене начина живота тих, многима далеких култура и ометала да се сагледа њихова повезаност са средином у којој су живели, животном заинтересованошћу и сопственим разумевањем живота који су водили.
} 
области може се рећи какав културни образац тај народ негује и колико је продубљен и префињен, или какав начин живота води та групација. ${ }^{88}$

Стари хуманисти су на основу античке филозофије обликовали образац који представља пример високог културног обрасца. Сагласно њему појединац мора научити да управља самим собом, да утврди мерило вредности, према којем би своје прохтеве и тежње одмеравао и ценио. Човек узима све ствари као делове једне целине, где сваку ствар поставља на своје место и одређује јој релативну вредност. При томе тежи складности и умерености у свему што ради или о чему промишља, јер само захваљујући томе долази до унутрашњег мира и равнотеже.

У литератури је већ примећено да је хуманистички културни образац дуго владао на Западу. И енглески „џентлмен“ и немачки „културни човек“ јесу културни обрасци с истом хуманистичком основом. У њима је наглашено пристојно понашање и лепо васпитање, али не као нешто спољашње и формално, него као нешто у чему се огледају лична вредност и способност за самодисциплину појединца. Хуманисти цене човека по томе какав је, а не по томе шта је постигао и колико је успео - тако су бар размишљали у XVIII и XIX веку. Како је приметио Слободан Јовановић, у првој половини XX века преовладало је мишљење да се више цене дела него карактери, а, како се чини, у многим друштвима слично размишљање се задржало и до данашњих дана.

За културни образац се каже да је допуна националном и политичком обрасцу, а Слободан Јовановић је почетком прошлог (XX) века уочио да се потреба за изградњом националног обрасца кроз историју српског народа осећала јаче него потреба за културним обрасцем. За недостатак те потребе он је кривио „наш индивидуализам“ (што би неко назвао и националним егоизмом), руковођен искључиво националним и политичким обрасцима. Уколико овакве особине кокетирају са национализмом, и то његовим најекстремнијим

\footnotetext{
${ }^{88}$ Слободан Јовановић, Културни образац, Стубови културе, Београд, 2005.
} 
облицима, долази до гушења сваке критичности и онемогућавања духовног развитка појединца. ${ }^{89}$

Изградња националног обрасца једног народа често је праћена многим утицајима који условљавају и одлике тог обрасца, а често их прате и бројне предрасуде и стереотипи својствени доживљају других народа о народу који је предмет посматрања. Да ли су Срби народ с ратничким особинама, каква представа влада о њима у очима странаца? Питање је истог нивоа као кад се размишља о томе колико је истине у томе да се уз Немца везују марљивост и испијање пива, или када се за Шкота каже да је шкрт. ${ }^{90}$

Након Балканских ратова, али и ратова који су следили, говорило се да су Срби један ратнички народ. Није сувишно рећи да и данас постоје таква размишљања. Међутим, рећи да је неко ратнички народ подразумева да тај народ жели борбу као занат, један такав народ има тежњу да у борби живи и да

${ }^{89}$ То, опет, изазива недоумицу око непостојања културног обрасца, као преко потребног код Срба, који важе за индивидуалисте. Више разлога се може навести за ту ускраћеност, па је тако један од њих да је за појединца питање народне/националне судбине било важније од питања његове личне судбине, да је у једном историјском тренутку низ околности довео до слабљења неговања унутрашњег живота, или је разлог тај што се природа индивидуализма појединаца на овим просторима одликује великом енергијом, али и великом амбицијом. Амбиција која покреће више на јавне подухвате и подвиге него на присна размишљања о себи самоме троши своју снагу на спољну друштвену акцију и тражи потврду своје вредности у јавним признањима и одликовањима, а мање цени вредност самодисциплине. Видети: Слободан Јовановић, Културни образаи, Стубови културе, Београд, 2005.

${ }^{90}$ Овакве концепције о стереотипима потичу, свакако, из домена имагологије, представе о појединачним нацијама на европском континенту. Она је позната још из антике у чувеном Епименидовом парадоксу („Сви Крићани лажу, каже један Крићанин“), а потврдио је и касније, 1781, чувени филозоф Имануел Кант, расправљајући о једној заблуди Дејвида Хјума („Ако унутар једне нације сваки појединац усваја у свој карактер извесне опште особине, онда сама нација нема свој карактер“). С тим се Кант не слаже, јер он сматра да „афектација једног карактера јесте управо општи карактер народа којем он припада“. На основу ових, али и других сличних мишљења, сматра се да је идеја стереотипа рођена највероватније са идејом нације и националним карактером. На путу уједињења европски народи понекад су се ослобађали наслеђеног бремена. Према: Мирјана Д. Стефановић, Кратки увод у историју српске културе, Службени гласник, Београд, 2008. 
је она нешто чему је тај народ стално посвећен. ${ }^{91}$ Чињеница је да су се Срби много борили, али не зато што је њихов начин живота подразумевао освајања, већ живот народа који се ослобађао, јер је био примораван да се бори и да се брани.

Истраживања о психичким типовима, карактеру и менталитету ${ }^{92}$ једног народа или етничких заједница леже у домену етнопсихологије, научне дисциплине која се конституисала средином XIX века и чији је научни легитимитет често оспораван. И поред оспоравања, још постоји интерес за даља етнопсихолошка проучавања, усмерена првенствено на истраживање везе између културе и личности и могућности дефинисања националног карактера. ${ }^{93}$

91 „Ратовање није израз борбеног нагона. Ратоборност код човека је тако незнатна особина његовог бића да може не доћи ни до каквог израза у међуплеменским односима. Када добије својство установе, облик који оно прима иде за другим токовима мисли, а не за онима који су садржани у првобитном подстицају. Борбеност није ништа више до почетни потез у образовању обичаја, потез до којег може и да не дође.“ Видети: Рут Бенедикт, Обрасии културе, Просвета, Београд, 1976, стр. 62.

92 Својевремено је негде око 1700. године у јужнонемачком простору (Штајерска) настала „таблица народа“, где су приказани представници десет европских народа и све антипатије, ксенофобије и предрасуде о појединачним народима. Ту је зачета идеја о биолошкогенетски утемељеној раси, о оним особинама које људску јединку повезују са сопственом нацијом - чак и када није одрастала унутар своје националне културе - а које је, опет, раздвајају од припадника другог народа. Десет мушких фигура (Шпанац, Француз, Холанђанин, Немац, Енглез, Швеђанин, Пољак, Мађар, Московљанин и Турчин или Грк) пореди се у седамнаест категорија: по темпераменту, природи, интелекту, пороцима, страстима, знању, ношњи, болестима, војничкој вештини, вери, политичком устројству итсл. Видети: Марија Тодорова, Имагинарни Балкан, Библиотека XX век, Београд, 2006, стр. $157-158$.

${ }^{93}$ Може се рећи да национални карактер представља идеју коју народ има о свом властитом карактеру, о својој историји, о својим задацима у будућности. Идеје које народ има о себи, о својој историјској судбини, првобитно налазе свој израз у народним предањима, легендама, а касније и у делима политичара, књижевника, па и научника. Уместо термина национални карактер данас се више употребљава појам наиионални идентитет, мада те две категорије ипак нису сасвим истоветне. 
Тако су у оквиру англосаксонске антропологије и франкофонске етнологије постигнути значајни резултати у истраживању етнопсихолошких особина и дефинисања извесних карактеристичних црта личности припадника одређених типова култура. Међу њима су неки већ раније поменути научници: Малиновски, Рут Бенедикт, Боас, Диркем, Леви-Строс, али и Маргарет Мид, Ралф Линтон, Леви-Брил, Еловел и други. У нешто одређенијем смислу ова проблематика се разматра и у оквиру етнопсихијатрије, нарочито развијене у Француској. Релевантне студије о психолошким, социјалнопсихолошким и психоаналитичким аспектима етнологије објављене у двотомној Onштој етнологији (Париз, 1968) указују на комплексност и обухватност таквих истраживачких приступа.

Рут Бенедикт је увидела да свака култура има нешто особено, што одговара карактеру појединца. У оном уобичајеном и стереотипном - да је човек увек и свуда исти и да се не мења - лежи и данас препрека да видимо суштинске разлике међу индивидуалним културама. Утврдила је да ни човек ни заједница, који припадају различитим културама, не могу бити исти, а да то не зависи ни од онога што многи називају расама, ма шта под тим разумели.

Расправама о менталитету неког народа и његовим посебностима често се супротставља чињеница да недостаје студиознијих, научно заснованих или бар ауторитативним ставовима подржаних расправа. Својевремено је Јован Цвијић рекао да је „човек за човека једна од тајни у коју се најтеже може продрети“. Идеје и побуде људских група често измичу прецизној анализи и проучавању. Наиме, Цвијић се сложио и са мишљењем антрополога, који су широм света проучавали мале народе племенског типа, да директно посматрање даје више тачнијих резултата у примитивним заједницама, јер још нису обрађене, модификоване и обликоване готово једнолико (глајхшалтоване) под утицајем цивилизације. Њихове психичке особине су простије и јасније. Оне се могу поузданије ухватити, а нарочито врло експресивне психичке особине етничких група патријархалног режима.

Проучавање примитивних друштава помаже у уочавању разлике између образаца специфичних за локалне културне типове и оних који су заједнички 
целој људској врсти. Истраживања те врсте омогућавају да се оцени и схвати важна улога културно условљеног људског понашања и не упадне у замку опасних генерализација, којима се могу стигматизовати читаве епохе људске историје.

\subsection{2 Заснивање вредности у оквиру једне културе}

Проблем вредности у једном друштву тесно је повезан са чињеницом разноликог изграђивања образаца културе. Свака расправа о вредностима обично се задовољава обележавањем извесних људских одлика као пожељних и указивањем на одређени друштвени циљ који би у себи садржао те вредности. Искоришћавање других у личним односима и претерани егоистични захтеви завређују осуду, док је утапање појединаца у групне делатности ствар за похвалу; добар је човек који не тражи задовољство ни у мучењу других нити у самомучењу и који је ра̀д да живи и да пусти друге да живе. Друштвени поредак остварен као коначан и савршен у којем ће људски живот достићи беспрекоран развитак јесте утопија и као такав је недостижан.

Све вредности које једно друштво промовише истовремено су вредности културе, јер је она на њима и утемељена. Темељна вредност за све културе јесте људски живот и све остале универзалне вредности (мир, праведност, част, лепота, право, мудрост) заправо стоје у одбрани живота као темељне вредности. Према многим мислиоцима вредности представљају „душу“ културе.

Постоје универзалне (трајне) вредности, које историјски трају и неодвојиви су део сваке културе. Оне су непревазиђене, изван су времена у којем су настале и историјски опстају за дужи низ година. Ту се, поред већ поменутих, убрајају вредности као што су: слобода, хуманост, храброст, истинољубивост, еколошка хармонија и сличне.

Постоје вредности значајне за друштвену заједницу, као што су одговорност, патриотизам, поштовање реда и закона, друштвена ангажованост. Вредности које указују на односе према другима свакако су: алтруизам, солидарност, 
кооперативност, толерантност, частан однос и друге. Развој појединца условљен је вредностима као што су: интегритет, позитиван однос према раду, стваралаштво, самоконтрола, скромност и предузимљивост.

Врхунске вредности културе трају дуго и доприносе успостављању континуитета укупне стваралачке праксе људског рода. Временом неке вредности губе своју социјалну функцију, али не губе своје уметничке одлике. Праве вредности нису историјски ограничене, већ трају и уједно подстичу стварање нових вредности. Материјалне вредности цивилизације често су супротстављене вредностима културе, тј. духовној димензији културе супротставља се псеудовредност масовне и потрошачке културе.

Одређене вредности културе могу бити и национално обележене. Сва друштва, а нарочито мултиетничка, мултикултурална и мултиконфесионална, без обзира на облик државног уређења, одликују партикуларне, али и доминантне вредности и интереси. Националне вредности су прокламоване и гарантоване правним поретком и од виталног су значаја за опстанак и развој друштва и државе. Често се вредности изједначавају са друштвеном нормом заснованом на неким правилима којима се регулишу односи у друштву, према друштву, према природи и себи самом, тако да се постигне друштвено пожељна оријентација у понашању.

У разматрањима културе најважнија ствар коју треба сагледати јесу управо оне вредности на којима се заснива, јер ће се само тако сазнати према чему су дате културе усмерене и због чега су организоване. Стварање, одржавање и развој вредности усмерава културу како на традицију, тако и на сталну промену и напредак. У свету је данас могуће утврдити доминацију два усмерења која се међусобно искључују; један део света се одликује доминацијом „економског материјализма, а други део углавном неразвијеног света „ритуализованим традиционализмом“. 94

У развијеном свету, сматра Ратко Божовић, култура је строго функционализована и инструментализована, тако да се врхунске

\footnotetext{
${ }^{94}$ Ратко Р. Божовић, Живот културе, „Филип Вишњић“, Београд, 2009.
} 
традиционалне вредности јављају више као експонати и музејске вредности. На другој страни, раширена потрошачка и масовна култура хомогенизује укус различитих категорија људи и тиме се човек као појединац утапа у обезличену масу. Све везано за традицију пасивизује се и тиме се губи могућност њеног делотворног очувања.

С друге стране, неразвијени део света нема делотворну традицију, већ гаји ограничавајући традиционализам, а исто тако није спреман за изазове савременог развоја, јер је економски неразвијен. При том, постоји константан притисак потрошачке психологије, која најчешће иде испред и изнад производних могућности друштва.

Да би једно друштво изабрало и сачувало вредности које су значајне за напредак и благостање, у условима тржишне економије и бројних ломова и турбулентних промена у сфери економије, политике и безбедности, потребно је да нађе праву меру како би се избалансирао и одржао задовољавајући ниво друштвено пожељних понашања и активности.

\subsection{3 Култура - доминантна и/или маргинална својства}

Многи ће се сложити, из данашње перспективе гледано, да је култура, као појава која се везује за човека од самих почетака његовог друштвеног организовања, у свим епохама имала одређени утицај на токове друштвеног развоја. Из историје је такође познато да је та иста култура, сходно различитим друштвеним околностима, често гушена, оспоравана и редукована на задовољавање интереса и потреба малобројних владајућих структура.

За исто време, реалне друштвене потребе и стварни значај и могућности учешћа културе у друштвеном животу били су другачији. Основне узроке за то треба потражити у свеколикој одређености културе и њене друштвене улоге карактеристикама владајућих друштвених односа. Наиме, друштвена улога културе била је условљена политичком, економском и социјалном организацијом конкретних друштвених заједница. 
И за културу, као и за друге форме егзистенције, били су карактеристични односи подређености и експлоатације. Општи закон поделе рада условљавао је не само дистанцирање подређених друштвених слојева од шире партиципације у култури, већ је и културу у целости удаљавао од основних животних токова. Култура као слобода остајала је на нивоу начелних могућности - замењена је илузијом о њеном постојању на такав начин да је допрла и до нашег времена кроз стваралаштво повлашћених појединаца. ${ }^{95}$

Када је реч о култури и доминантним или маргиналним својствима, заправо је могуће представити више нивоа анализе. ${ }^{96}$ Шездесетих година XX века многи антрополози, социолози и економисти (углавном марксистичке оријентације) бавили су се проблемом односа између заједница и култура на глобалном нивоу и уочили неравноправност, која се може свести на однос центра и периферије. На неравноправност тог односа највише су указивали они који су желели да истакну израбљивање као обележје односа између колонијалистичког центра и колонизованих области, или, после колонијализма (након Другог светског рата), између индустријски и технолошки напредног центра и периферије као изворишта сировина и радне снаге.

У свим антрополошким анализама из тог периода у првом плану су друштвена, политичка и економска структура. Без обзира на отвореност, те анализе не узимају у обзир „културне“ аспекте, јер их ови аналитичари често сврставају у надградњу и сматрају их идеолошким и другоразредним у односу на политичке и економске факторе, а посебно када је реч о односима између центра и

95 Милош Илић, Социологија културе и уметности, седмо издање, Научна књига, Београд, 1983.

96 Доминантна својства културе могу се односити и на претпоставке, вредности, норме, симболе и веровања које деле сви њени чланови у нижем или вишем степену. Маргинална својства обухватају исти садржај, али који дели мања група у оквиру неког ентитета. Маргинална својства се могу изразити и кроз категорије као што су супкултура, контракултура и сличне. Наравно, није увек могуће правити овакву дистинкцију, посебно ако се сагледа тумачење културе из призме савремених теорија и „рађања“ новог типа културе у времену информатичко-технолошке револуције и глобалне експанзије мултинационалног капитализма. 
периферије. Познато је да је однос између центра и периферије неравноправан, пре свега у области економије, где је центар својом економијом тлачио, мењао, па и уништавао економију периферије.

Питања која су се у међувремену отворила усмерена су ка култури и размишљањима да ли се процеси у култури одвијају упоредо с оним што се збива у политици и економији. Опште сагле́дање глобалних прилика са аспекта културе даје нам једну знатно комплекснију слику у односу на представу о центру, који влада, и периферији, која се покорава. ${ }^{97}$

Многе ослободилачке и социјалне револуције током двадесетог века носиле су са собом истовремено и замах културног преображаја. Оне су, као по правилу, прерастале и у културне револуције, чије победе остварују најшире масе, прекрајајући дотадашње уске и елитистичке концепте културе. Огроман ослобођени културни потенцијал до тада гушене и спутаване стваралачке моћи милионских популација потпуно новом снагом је покренуо развој савремене културне историје. Културне вредности и садржаји престају да буду само привилегија и потреба фаворизоване мањине, већ улазе у хоризонт живљења већине чланова друштвене заједнице.

Наравно, анализа доминантних или маргиналних својстава културе може се сместити и у оквир прихватања културе као фактора/димензије који својим могућностима, значајем и улогом у конструисању и креирању друштвених односа далеко превазилази улогу и значај економских или политичких структура. Или, блаже речено, култура се више не схвата као затворен систем идеја, симбола и значења које деле сви припадници неког друштва, већ пре као апстрактна категорија чије су конкретне манифестације фрагментоване и уско испреплетене са силама економије и политике. Која ће димензија превладати, то је већ ствар комплексних друштвених околности, али и теоријских тумачења и вишестране анализе друштвених прилика.

Из свега реченог произлази да је у савременом раздобљу људске историје питање друштвене улоге и значаја културе добило своју пуну легитимност.

97 Уго Фабијети, Роберто Малигети, Винченцо Матера, Увод у антропологију, Клио, Београд, 2002, стр. 201-202. 
Токови савременог друштвеног развоја својим бројним карактеристикама указују баш на нужност још дубљег и чвршћег повезивања културе са свим токовима друштвеног живота што ће условити и убудуће снажити теоријско интересовање за промишљање тих односа. ${ }^{98}$

При том се чак указује на чињеницу да је лоше постављено питање какво место култура заузима у друштву, јер се не може одредити неко посебно место културе, пошто људско друштво претпоставља да су култура и њени елементи интегрисани у све друштвене појаве и процесе. Зато је можда најбоље рећи да културу третирамо као компоненту целокупног друштвеног живота и живота појединца, да она не представља сферу за себе, нити у облику суперструктуре нити у облику подструктуре (у оном смислу у којем се о економији и политици може говорити као о подструктурама глобалне структуре друштва).

\subsection{4 Културне разлике као фактор стабилности или социјалне напетости}

Колико год да има размишљања која су неповерљива према тој чињеници, оно што стварно повезује људе међу собом јесте њихова култура - идеје и мерила који су им заједнички. Ако уместо одабирања неког симбола, као што је крвно наследство, и његовог проглашавања за бојни поклич, нација обрати пажњу више култури која сједињава њен народ истичући високе врлине те културе, а одајући признање и другачијим вредностима које се могу развити у некој различитој култури, она ће реалистичким мишљењем заменити једну врсту симболизма који је опасан, јер је извор обмана. ${ }^{99}$

98 Интересовање теоријских дисциплина за подручје културе такође је попримило битно другачија обележја, јер се култури више не приступа као засебном и аутономном подручју које постоји и реализује се издвојено од свих других облика људске праксе. Тиме се и у сфери науке све више негује приступ којим се наглашава најнепосреднија повезаност културе са свим осталим подручјима друштвеног живота.

99 Разни народи исте конфликте решавају на различите начине - култура је извор конфликта, али и компонента њиховог решавања и основно питање је: како је могуће успоставити 
Култура је контекст, ако је интегрисан и координиран, може помоћи актерима да превазиђу чак и озбиљне препреке у сарадњи. Насупрот томе, култура се, нажалост, често јавља као одлучујући извор потенцијалног сукоба или неусаглашености.

Криза идентитета која је наступила на глобалном плану током деведесетих година двадесетог века учинила је да културни идентитет одређује место државе у светској политици, али исто тако и њене пријатеље, односно непријатеље. Познато је и кроз историју, да када наступи криза идентитета, прво што повеже људе јесте „крв“, уверења, вера и породица. Удруживање настаје на основу сличних или истих предака, на основу религије, језика, заједничких вредности и институција.

Односи између група из различитих цивилизација и култура нису увек били блиски и пријатељски, већ су често кроз историју били антагонистички. Тако је и данас, а тако ће бити и у будућности, предвиђа Семјуел Хантингтон у Сукобу цивилизащија. Он је уочио да култура и културни идентитет обликују моделе кохезије, дезинтеграције и сукоба у послехладноратовском свету. И поред тога што су се умањиле разлике на идеолошком, политичком или економском плану, на културном плану су се још више продубиле.

Исти аутор наводи више чињеница које објашњавају зашто културне разлике промовишу неслагања и сукобе: ${ }^{100}$

- Све је виши степен у којем се људи широм света културно разликују, што значи и да сукоби између културних група све више добијају на важности.

- Упадљивост културног идентитета је углавном резултат друштвеноекономске модернизације на индивидуалном нивоу, на којем маргинализација и отуђење стварају потребу за значајнијим

стабилан поредак у условима разлика међу културним моделима појединих народа (политичко̄ се не може разумети без културе, од које зависи како појединци и групе решавају сукобе).

100 Семјуел Хантингтон, Сукоб циивилизащија, ЦИД, Подгорица, и Романов, Бања Лука, 2000, стр. $143-145$. 
идентитетима и на друштвеном нивоу, на којем повећане способности и моћ незападних друштава подстичу ревитализацију домаћих идентитета и културе.

- Идентитет, на било којем нивоу, може да се одреди само у односу на „другу“ (особу, племе, народ, расу, цивилизацију). Односи између држава из исте цивилизације историјски се разликују од односа између држава из различитих цивилизација. Тако су правила хришћанских нација у међусобним односима била другачија од правила у односима са Турцима, на пример.

- Извори сукоба између држава и група из различитих цивилизација јесу они који су у великој мери генерисали сукоб између група: контрола људи, територије, богатства и ресурса и релативна моћ, тј. способност да се нечије сопствене вредности, култура и институције наметну другој групи. Ипак, сукоб између културних група може да обухвати и културна питања.

- Сукоби су одувек присутни, јер се каже да је људски мрзети. За самоодређење и мотивисаност људима су потребни непријатељи: на послу, у политици. Они који су различити - некако по аутоматизму се доживљавају као претња и њима се не верује.

Не можемо се сложити у сваком сегменту оваквог тумачења разлога за сукоб и нетрепељивост коју доносе културне разлике. Као што има аргумената за све заоштреније културно одвајање и раздвајање међу неким друштвеним групама, тако имамо и аргументе (пре свега посматрано у глобалном контексту) који наводе све више примера културног приближавања и устројавања заједничких културних елемената који спајају и мире народе, друштвене групе и појединце. Такође, констатација да је људски мрзети, на пример, нема одговарајућег научног, теоријског утемељења и објашњења.

Наравно, не можемо говорити о свеукупној култури као потенцијалном узроку социјалних напетости, па чак и као безбедносном проблему, већ издвојити оне елементе или димензије које ће послужити за анализу позитивних или негативних последица које производе одређени аспекти културе. 
Један од тих аспеката управо су културне разлике о којима је говорио и Хантингтон. Кључни проблем може да представља управо то да се неретко културне разлике отворено или прикривено злоупотребљавају, односно инструментализују за одређене политичке циљеве. Културна различитост готово је свакодневни разлог убијања у многим земљама, па и европским, неко би рекао - нарочито на Балкану. Оног тренутка када борба за признавање и поштовање културних разлика прерасте у нешто сасвим друго, нешто много екстремније, као што је борба за територију, посебне привилегије и подривање успостављеног поретка, прерасте, дакле, у насиље и у један деструктиван процес који даје једну потпуно нову димензију тој борби. Према томе, једна од најактуелнијих тема у савременом политичком дискурсу неизбежно је повезана са политиком признавања и праштања у којој мери и којој форми треба да буде призната борба за очување културних разлика.

Међутим, улога културних разлика је од виталног значаја и за процес друштвене интеграције, од чијег успешног спровођења зависе стабилност, па чак и опстанак друштва и државе, што се може поистоветити и са биодиверзитетом који је на делу у природи. У зависности од начина на који ће бити артикулисане и третиране од стране државе, културне разлике могу да постану фактор интеграције или пак, као што смо видели, да прерасту у фактор дезинтеграције. Бери Базан, истакнути теоретичар студија безбедности, такође је уочио значај решавања социјалних питања и очувања културне и верске самобитности појединих друштвених заједница (у теорији познато као социјетална безбедност), како би се избегли конфликти. Као важан предуслов успешне националне безбедносне политике он је истакао управо смањивање противречности између државне и социјеталне безбедности.

Такође је важно уочити да се културне разлике не могу третирати као изолован фактор који утиче на процес друштвене интеграције и стабилности у једном друштву. Важни су и многи други друштвени моменти и токови у држави, као што су социо-економски положај грађана, интегрисаност припадника различитих културних и етничких заједница у свим сферама друштвеног живота, функционисање правне државе и поштовање универзалних вредности. 
Наравно, у теорији су се развили и профилисали одређени концепти (асимилација, мултикултурализам и интеркултурни дијалог), који су послужили политичким чиниоцима да у пракси покушају да помире и реше културне разлике, при чему је сваки од њих показао одређене предности, али и бројне слабости. У даљем тексту бавићемо се мултикултурализмом као алтернативним концептом и интеркултурним дијалогом.

\subsection{5 Мултикултурализам}

Као што је већ познато, културна хетерогеност је одлика највећег броја данашњих земаља. ${ }^{101}$ Културна разноликост сваког савременог друштва вишедимензионална је и, почев од оне биолошке/полне, која се културно преводи у разлику у роду, обухвата и генерацијску разлику, као и разлике које су социјално условљене и тичу се националне, религијске, регионалне припадности и припадности језичкој заједници.

Услед ове разноврсности, јавља се читав низ питања која могу бити предмет спора. Успостављање регионалне аутономије, остваривање језичких права, политичко представништво, имиграциона политика, национални симболи су само нека питања око којих се сукобљавају националне мањине и националне већине. Највећи изазов са којима се суочавају данашње демократије управо је решавање ових питања на најприхватљивији могући начин.

Модерна држава је одувек покушавала да користи моћне централизујуће силе да успостави културну хомогеност, која у основи поистовећује јединство са хомогеношћу и једнакост са униформношћу. Међутим, савремена мултикултурна друштва представљају јединствен историјски феномен, који отвара нова питања и захтева нове концепте за разумевање својих противречности и развојних перспектива. Концепт мултикултурализма је један

101 Према најновијим проценама, у 184 независне државе у свету постоји око 600 језичких и 5.000 етничких група. Исланд и Кореја се наводе као примери земаља које су мање или више културно хомогене. Видети: Вил Кимлика, Мултикултурализам - мултикултурно грађанство, ЦИД, Подгорица, Јесенски и Турк, Загреб, 2004. 
од тих концепата и он се често објашњава као политички и друштвени одговор на социјалну ситуацију у којој више не постоји консензус о јединственој националној култури каква би требало да интегрише друштво које је мултикултурно.

Појам мултикултурализам често подразумева различите облике културног плурализма, од којих сваки може представљати одређени изазов. Мањине се инкорпорирају у политичке заједнице на различите начине, од освајања и колонизације претходно самоуправљајућих друштава до добровољне имиграције појединаца и породица. У односу на то како је извршена инкорпорација можемо утврдити природу мањинске групе и тип односа који њени припадници желе да изграде са ширим друштвом.

Како је у оквиру своје студије о мултикултурализму истакао Вил Кимлика, могу се разликовати два модалитета културне разноврсности:

1. Културна разноврсност која настаје из инкорпорације претходно самоуправљајућих, територијално концентрисаних култура у већу државу. Ове инкорпориране културе, које називају националним мањинама, по правилу настоје да се одрже као особена друштва поред већинске културе и захтевају различите видове аутономије или самоуправе како би обезбедиле свој опстанак као особена друштва.

2. Културна разноврсност настаје као резултат индивидуалне или породичне миграције. ${ }^{102}$ Такви имигранти често образују лабаве асоцијације које се називају етничке групе. Оне по правилу желе да се интегришу у шире друштво и да буду прихваћене као његови пуноправни чланови. Иако оне често траже шире признање својих етничких идентитета, њихов циљ није да постану сепаратне и самоуправљајуће нације унутар ширег друштва, већ да модификују

102 Аустралија, Канада и САД имају три највеће стопе имиграције per capita у свету. Преко половине целокупне легалне имиграције у свету тиче се ове три земље. 
институције и законе матичног друштва како би их прилагодили културним разликама. ${ }^{103}$

Једна те иста земља може бити истовремено и мултинационална (као резултат колонизације, освајања или конфедерализације националних заједница) и полиетничка (као резултат индивидуалне и породичне имиграције).

Неки аутори, политички званичници или представници цивилног друштва, термин „мултикултурно“ употребљавају на шири начин, тако да он обухвата широки спектар неетничких друштвених група које су, из различитих разлога, искључене или маргинализоване у односу на доминантну друштвену матицу. Оваква употреба датог термина нарочито је раширена у САД, где заговорници мултикултурних наставних програма настоје да промене ситуацију искључених група, као што су хомосексуалци, жене, мануелни радници, атеисти и комунисти.

Све то уједно, још једном, указује и на сложеност израза култура. Многе од ових група имају особену културу у једном здраворазумском смислу те речи тј. овде се култура односи на особене обичаје, перспективе или етосе група или асоцијација, па се, према томе, може говорити о „култури хомосексуалаца“ или чак „бирократској култури“. То је можда и најлокалније значење термина „култура“. На другом екстрему, употребљавајући „културу“ у најширем смислу, можемо рећи да све западне демократије деле исту културу - тј. да све оне представљају модерну, урбану, секуларизовану, индустријску цивилизацију, насупрот феудалном, пољопривредном и теократском свету наших предака.

Уколико култура значи „цивилизованост“ народа, онда практично сва модерна друштва деле исту културу. Ако се култура одреди на овај начин, тада ни најмултинационалније земље, попут Швајцарске, или пак полиетничније земље, попут Аустралије, нису много мултикултурне, утолико што и различите националне и етничке групе партиципирају у истом модерном индустријализованом начину живота.

103 Вил Кимлика, Мултикултурализам - мултикултурно грађанство, ЦИД, Подгорица, Јесенски и Турк, Загреб, 2004, стр. 21-22. 
Најчешће гледиште је да је држава мултикултурна ако њени чланови или припадају различитим нацијама (мултинационална држава) или су имигрирали из различитих нација (полиетничка држава) и ако ова чињеница представља важан аспект личног идентитета и политичког живота. Неки други у појам укључују и енклаве, друштвене покрете и добровољне асоцијације. Маргинализација жена, хомосексуалаца, лезбијки, хендикепираних пресеца етничке и националне границе - она је својствена већинским културама у истој мери као и националним мањинама и етничким групама, а против ње се иначе мора борити на свим местима.

Постоји мишљење да истинска либерална концепција националног припадништва треба да се заснива искључиво на прихватању политичких принципа демократије и права, а не на интеграцији у посебну културу. За ову концепцију се каже да је она то што разликује „грађански““104 или конституционални национализам од нелибералног, „етничког“ национализма. По Кимлики је то погрешно. И други мултикултуралисти замерају носећем либералном постулату по којем је држава пуки конвенционални идентитет чији правно-политички идентитет не зависи од културно-етничког идентитета њене популације, тј. од обичајносних норми које следе њени чланови.

Наиме, полазна тачка либерала при конципирању устава јесте апстрактни грађанин, тј. сопство невезано за било какве примордијалне, чланством у посебној заједници посредоване идентитете. При том, закони и политичке институције изведени из овог либералног устава и његових базичних принципа постављају се као културно-етнички неутралне инстанције, а то се оправдава ставом да је културно-етнички идентитет људи ирелевантан за њихов политички идентитет. Међутим, према мултикултуралистима културноетнички идентитет човека, као неодвојив од културно-етничког идентитета посебне заједнице којој овај припада, није ирелевантан за његов политички

104 Чистом грађанском принципу, дакле, иманентан је државно-територијални појам нације, који је потпуно очишћен од културно-етничког елемента, што имплицира изједначавање националности и држављанства, или, а то је исто, одвајање етницитета од државе и његово измештање у сферу цивилног друштва. 
идентитет, јер ће огромна већина људи показивати тенденцију да се при доношењу политичких одлука (рецимо, гласање на изборима) руководити не само чисто политичким критеријумима већ и критеријумима културноетничког припадништва. ${ }^{105}$

У либерално-демократској теорији се, иначе, разликују две традиције: једна која говори о политици једнакости, према којој сви појединци заслужују једнако поштовање и једнака права; и друга - политика различитости, која се темељи на признању јединствених идентитета појединаца и група. Неки аутори сматрају да се оба гледишта темеље на поимању једнаког поштовања, па самим тим посматрају и мултикултурализам као логичан продужетак политике једнаког поштовања и политике признања. С тим у вези, многе државе траже начине и облике политичких решења у пружању трајне основе за решавање проблема који настају због етничких, националних, верских и других различитости између разних делова становништва.

У Европској унији постоје и дефинисани стандарди са којима се морају усагласити правни системи свих нових чланица. Питање мањина је важан проблем организације политичког, културног и економског живота, а не споредни феномен који се може решити на технички начин. Решити питање мањина на правним основама има за циљ интеграцију мањина у друштво - у његове политичке, привредне, културне и друге облике и установе. На тај начин би се избегле асимилација и гетоизација, а ускладили односи и сарадња свих мањина и већине на начелима владавине права и демократског уређења друштва. Тешкоће настају јер постоје огромне разлике у економском положају и у инфраструктури образовне мреже и нивоу образовања, као и у материјалним и људским ресурсима појединих мањина.

Као што смо већ нагласили, да би се превазишла ова ситуација, либерали су сматрали да мултикултурна друштва могу опстати као политичке заједнице једино ако остваре раздвајање културног од политичког идентитета. Међутим,

\footnotetext{
105 Видети шире: Слободан Дивјак, Проблем идентитета: културно, етничко, национално и индивидуално, Службени гласник, Београд, 2006, стр. 76 и даље.
} 
свакодневни и политички живот у мултикултурним срединама донекле је демантовао ове тврдње. ${ }^{106}$

У сваком случају, крајњи исход (бар на дневнополитичком нивоу) није задовољавајући, а један од узрока се може тражити и у различитом схватању појма нације, које се знатно разликује када су у питању европско и америчко тумачење. Током већег дела своје историје САД су себе сматрале нацијом имиграната, али са језгром културе коју имигранти морају да прихвате у добро знаном мултикултуралном процесу melting pot-a. Свако може да постане Американац ако прихвати језик и доминантну културу нације. ${ }^{107}$ Ово је остављало доста простора за посебност, али су неке вредности морале да буду заједничке. Тако је и држављанство постало правни концепт. Захтевало је

106 Када је немачка канцеларка Ангела Меркел крајем 2010. године изјавила да је концепт мултикултурализма у Немачкој „потпуно пропао“, изазвала је бурне реакције, а међу њима и реакције потпуног одобравања таквог става. Наравно, долази до нових преиспитивања и тумачања оправданости и сврсисходности овог концепта. Овај концепт је у својој основи либералан и хуман, те је као такав нудио мигрантима (пре свега Турцима у Немачкој осамдесетих година XX века) велику погодност: да задрже своју културу, али да буду лојални држави. У складу са тим концептом, од турских миграната се није очекивало да се асимилују у немачку културу. Уместо тога, они су задржали сопствену културу, укључујући и језик и веру, и она је коегзистирала са немачком културом. Отуда је постојао велики број странаца, од којих многи нису говорили немачки и по правилу нису делили немачке и европске вредности. Док поштује различитост, деловало је да таква политика купује лојалност миграната. Дубље објашњење било је да Немци нису желели, а нису ни знали како да асимилују културно, језички, верски и морално различит свет. Мултикултурализам није толико представљао поштовање различитости колико начин да се избегне одговор на питање шта значи бити Немац и на који би начин странци могли да постану Немци. Видети: www.stratfor.com/weekly/20101018_germany_and_failure_multiculturalism.

107 Усељеници у САД морају не само да испоље лојалност према демократским принципима, већ и да уче енглески језик и историју своје нове земље. Оно што разликује грађанску нацију од етничке нације није само одсуство било које културне компоненте у националном идентитету, већ пре чињеница да се свако може интегрисати у заједничку културу, без обзира на расу или боју коже. 
пролазак кроз процедуре, полагање заклетве и неговање заједничких вредности. Националност је могла да се стекне - имала је своју цену. ${ }^{108}$

С друге стране, схватање нације по етничком пореклу (својевремено је то важило за Французе, Пољаке или Грке, на пример) значило је не само научити језик или усвојити заједничке вредности, већ и имати заједничко порекло, историју, културу, мит о заједничким прецима и сличне елементе. Мултикултурализам је на европском тлу резултовао трајним отуђењем имиграната. ${ }^{109}$

Због специфичне историје и решавања проблема немачке нације холокаустом, као и вишедеценијског избегавања расправе о овом питању, пример Немачке је специфичан и другачији када је у питању примена концепта мултикултурализма. Међутим, и друге европске земље и њихови лидери (у Великој Британији Дејвид Камерон, почетком 2011, износи сличне ставове) доводе у сумњу и оспоравају значај и примену овог концепта.

Бројни су покушаји да се културна различитост у једном друштву не претвори у озбиљну претњу, која лако може да наруши друштвене односе. Како се може закључити у овом делу, концепт мултикултурализма је показао и своје предности, али и мане у покушају да реши потенцијалне проблеме који из културне различитости могу произаћи. С тим у вези, појавио се један нов концепт који покушава да надомести недостатке и слабости концепта мултикултурализма. У питању је интеркултурни дијалог.

\footnotetext{
108 www.stratfor.com/weekly/20100719_geopolitics_nationalism_and_dual_citizenship

109 Занимљив пример су они немачки Турци који су задржали свој идентитет, више се везујући за земљу порекла (која је домовина), него за Немачку (која је погодност). Показало се да идеја о везаности за домовинску културу и истовремено компатибилности са политичком лојалношћу држави у којој неко живи и није тако продуктивна. Немачка се нашла у „проблему“ - у својој средини има велики број странаца, а, према перцепцији владајуће политичке елите или једног дела грађанства, бар неки од тих муслиманских имиграната повезани су и са потенцијалним тероризмом. Ову чињеницу, опет, може демантовати „случај Брејвик“, тј. класичан облик тероризма извршен од стране „домаћег“ терористе, а не имиграната.
} 


\subsection{6 Интеркултурни дијалог}

Да би се спречиле бројне етничке, верске, језичке и културне поделе и да би сви живели у достојанству, поштујући универзалне вредности које дели читаво човечанство, неопходно је на један конструктиван и демократски начин прићи различитим идентитетима. Управо је дијалог често средство за редефинисање идентитета, посебно оних који су конституисани према потпуној и оштрој разлици. У теорији постоје бројна разматрања и истраживања о дијалогу као форми комуникативне активности и рационалности помоћу које актери укључени у однос сукоба или потенцијалног сукоба те́же томе да постигну универзални консензус, заснован, пре свега, на снази бољег аргумента.

Пракса нуди мало другачија решења, која нису усмерена ка универзалној сагласности, већ према покушају да се актери поставе изнад апсолутног односа између идентитета и разлике - основе сукоба - и усмере према неком облику заједничког идентитета и језика који би произвео повољне услове за могућност разговора који ће донети прихватљиво решење за обе стране у „сукобу“.

Управо због тога, једна од тема бројних билатералних и мултилатералних сусрета између европских земаља у првој деценији двадесет првог века била је да су стари приступи управљања културном разноликошћу превазиђени у друштвима у којима постоји висок степен такве разноликости, који је у сталном порасту. За оно што је до „недавно“ било препоручени политички приступ „мултикултурализам“ показало са да садржи бројне слабости. Пошто не постоји жеља да се врати ранијој тези о асимилацији, да би се добило инклузивно (укључиво) друштво, потребан је и нов приступ, а интеркултурни дијалог може бити пут који треба следити. ${ }^{110}$

Тај механизам вођења интеркултурног дијалога подразумева отворену и достојанствену размену мишљења између појединаца, група различитог

110 Савет Европе је 2008. године на министарској седници усвојио Белу књигу о интеркултурном дијалогу, који је представљен као модел за управљање културном разноликошћу који је окренут будућности. Основна идеја водиља овог концепта јесте „живети заједно као једнаки у достојанству“. 
етничког, културног, верског и језичког порекла и наслеђа, уз заједничко разумевање и уважавање. Присутан је на свим нивоима у оквиру једног друштва, између више друштава и између Европе и других земаља. Интеркултурни дијалог је важан за управљање у вишеструким културним опредељењима, а може се разумети и као механизам за усклађивање идентитета, за нови почетак и нова искуства, који додаје нова обележја идентитета без одрицања од сопственог порекла.

Према документу Савета Европе, као основни предуслови за интеркултурни дијалог издвајају се:

- људска права, демократија и владавина права,

- једнако достојанство и узајамно поштовање,

- полна једнакост и

- отклањање баријера које спречавају интеркултурни дијалог.

Поштовање људских права, демократија и владавина права неопходне су карактеристике инклузивног друштва, у којем ниједан појединац није маргинализован и изопштен. Он је моћно средство медијације и помирења: конструктивним залагањем за превазилажење културних подела он се бави истинским проблемима друштвеног раслојавања и несигурности, док истовремено негује интеграцију и социјалну кохезију.

Једнакост и узајамно поштовање представљају важну основу за изградњу интеркултурног дијалога и имају суштинску важност у уклањању баријера за његову реализацију. Они доприносе јачању демократске стабилности и борби против предрасуда и стереотипа у јавном животу и политичком дискурсу, олакшава стварање коалиција између различитих културних и верских заједница и може спречити ескалирање конфликата и у ситуацијама након конфликта или током ,замрзнутог конфликта“.

Родна равноправност такође даје позитивну димензију интеркултурном дијалогу. Сложеност идентитета сваког појединца пружа могућност да се додатно размисли о развоју солидарности упркос постојању бројних стереотипа и да се самим тим појачају перспективе једне заједнице. Сама 
чињеница да је полна неједнакост поље на којем се ломе копља указује на то да интеркултурни пројекти на којима се ангажују жене које припадају „мањинској“ и „већинској“ заједници може довести до стварања заједничког искуства.

Тамо где не постоји напредак у смеру остваривања једнакости, друштвена напетост може и сама да се манифестује у културној арени, чак и када узрок немира лежи негде другде, културни идентитет лако може бити предмет жигосања. $^{111}$ Интеркултурни дијалог је представљен као важна потпора изградњи једног новог друштвеног и културног модела, који све више узима маха у европском простору. То је модел који се мења великом брзином и који ће омогућити да сви који живе у културно разноликим друштвима остварују своја људска права и основне слободе. То је уједно и један од највећих захтева савременог доба, а биће важан и у годинама које долазе.

\section{3 Уобличавање (националне) културе}

Један од уобичајених начина разумевања културе јесте и њено посматрање на основу приказа компоненти које је сачињавају, односно уобличавају. Да бисмо их представили, описали и разумели, морамо им дати јасну димензију културе, кроз коју ће они добити свој пуни садржај, а такође се јасно и прецизно изразити. Симболи, вредности, веровања, обичаји, ритуали, језици и праксе преносе се новим члановима који прихватају културу, пре свега, друштвене групе којој припадају.

Процес идентификације са елементима специфичне културе подразумева снажан емоционални улог, а он је најинтензивнији, па често и најбогатији, када су у питању верски, етнички и/или национални идентитет. Из ове тврдње проистичу две ствари: прво, удео културе у фаворизовању стварања сложених односа између чланова дате заједнице са допуштењем да препознају сваког

${ }^{111}$ Подсетимо се још једном примера муслимана̂ и сврставања у категорију потенцијалних терориста. 
другог члана (нације) и замисле њихову заједницу као одвојену и дистанцирану од других, друго, индивидуе социјализоване у оквиру посебне културе те́же њеним унутрашњим симболима, веровањима, обичајима, вредностима, као делом који и њих уобличава. ${ }^{112}$

Посредством церемонија, обичаја и симбола сваки припадник заједнице учествује у њеном животу, емоцијама и врлинама и, преко њих, поново се посвећује њеној судбини. Артикулишући и чинећи опипљивом идеологију национализма и појмове нације, церемонијал и симболика доприносе осигуравању континуитета једне апстрактне историјске и судбинске заједнице.

Карл Дојч [Karl Deutsch] је дефинисао нацију као културни ентитет који се односи на процесе комуникације, фундаменталне у креирању кохерентних друштава и култура. ${ }^{113}$ По његовом виђењу се управо припадност народу/нацији састоји у широкој комплементарности друштвене комуникације. Она се састоји у способности да комуницирају ефикасније и преко широког спектра тема, са члановима једне велике групе, а не са „аутсајдерима“. Комуникација захтева употребу одређеног језика познатог припадницима нације, коришћење симбола, ритуала, обичаја и усвајање вредности које су од посебног значаја за дату заједницу.

\subsection{1 Симболи}

Лесли Вајт је својевремено рекао да је „симбол оно што је преобразило човека од обичне животиње у људску животињу“ и да „без симболичког општења ми уопште не бисмо имали културу“.

Реч „симбол“ потиче од старогрчке речи symballein, која значи „заједно“. Њено фигуративно коришћење настало је у обичају ломљења глинене плочице да би се закључио неки уговор или споразум: свака уговорна страна добила би један

\footnotetext{
${ }^{112}$ Montserrat Guibernau, The Identity of Nations, Polity Press, Cambridge, UK, 2008.

${ }^{113}$ Karl W. Deutsch (1966), Nationalism and Social Communication, second edn, New York, MIT Press; према: Антони Д. Смит, Национални идентитет, Библиотека XX век, Београд, 2010.
} 
од сломљених делова, који би се приликом поновног састанка слагали као слагалица. Ови делови, који су идентификовали једно од умешаних лица, били су познати као symbola, тако да симбол не представља само нешто друго него указује и на то да „нешто“ недостаје, невидљиви део који треба да оствари потпуност или целовитост. ${ }^{114}$

Читава теорија симболизма састоји се у дефиницији симбола или идеје као нечег што се може физички забележити, описати или дефинисати. Идеје, мисли и осећања морају се обрађивати са свим осталим видовима културе, и функционално и формално.

Функционални приступ нам омогућава да одредимо прагматички контекст једног симбола и докажемо како у културној реалности неки вербални или други симболички чин постаје стваран само кроз учинак који производи. Формални приступ је основа, а уједно и потврда нашег убеђења да је у социолошком или етнографском теренском раду могуће с високим степеном тачности и објективности дефинисати идеје, веровања, емоционалне кристализације једне сасвим другачије културе.

Симболи се налазе у суштини културног идентитета, будући да обликују све аспекте живота. Они се користе свим изворима - живим и неживим - у свом надахнућу и појављују се у свим појмљивим облицима: као слике, метафоре, звукови и гестови, као персонификације у миту и легенди, или се одигравају

114 Лексема symbolon може се превести и у смислу „знака, знамења“. Најједноставније, као што лист хартије има две стране, тако и симбол има два лица: а) са предње стране он је физичка, материјална ствар, дакле, он мора бити најпре некакав предмет, звучни сигнал, гест, реч, слика, које ја запажам, видим, чујем, могу да додирнем; а затим б) мене, као људско биће, присуство тога што видим и чујем, нагони да замислим „нешто друго“, што се налази с оне стране „чулног“. То је неки нематеријални, само људима схватљив смисао. Симбол је, дакле, људска замисао, пројекција, да у чулним предметима „види“ још и нешто друго, што животиња, на пример, није у могућности. Симбол је тако, двостран: специфичан материјални објект - слика, тон, волумен, гест, нешто објектно, страствено, дато у простору и времену, али чији манифестни објектни план претпоставља један други, невидљиви или иматеријални смисао. Видети: Марк О’Конел и Рејџ Ери, Илустрована енцииклоедија знакова и симбола. Идентификација и анализа визуелног речника који формулише наше мисли и диктира реакције на свет око нас, „ЈРЈ“, Београд, 2007. 
кроз обред, ритуал или обичај. Још од најстаријих времена појам симболике се појављује у свим људским културама, друштвеним структурама и религијским системима, доприносећи гледањима на свет и обликујући људско схватање космоса и нашег места у њему. Велика моћ симбола одавно је позната: кажу да је старокинески мудрац Конфучије рекао: „Светом владају знакови и симболи, не речи или закони. “115

Симболика се одувек користи за означавање идентитета и за потврђивање привржености друштвеној групи или „породици“, основним јединицама друштва. Било да се заснивају на заједничким веровањима или заједничким интересима и активностима, све организоване групе - на локалном, регионалном, националном или међународном плану - имају сопствене симболе идентитета. Они могу да буду у облику тотема, барјака, застава ${ }^{116}$ или изражени кодексима одевања или преко ритуализованих форми понашања. Једна од важних карактеристика такве симболике јесте њена видљивост: она је планирана да обезбеди лако препознатљив знак групног идентитета, што је начин кодификовања и структурисања друштвених односа, прављења разлике између оних који су „у игри“ и оних који су „ван игре“, у циљу побуђивања емоционалног одговора, као што су страх, поштовање, понизност или понос, код свих који је виде, чују или на неки други начин перципирају.

${ }^{115}$ Исто.

116 Употреба платнених застава пренета је из Кине у Европу, где су се најпре користиле као војни и церемонијални знакови, али касније и као начин идентификовања владара, њихових земаља и националности на мору. У XVII веку дошло је до увођења стандардизованих пуковских боја, ратних ознака, застава на бродовима и кућних застава трговачких компанија (претеча модерног логоа). Прве националне заставе на копну појавиле су се у последњој четвртини XVIII века. Током XIX и XX века дошло је до појаве мноштва других застава: владиних служби и чиновника; покрајинских застава; застава ранга у свим деловима оружаних снага; и застава школа, универзитета, научних института, организација, политичких партија, синдиката и герилских покрета. Такође постоје заставе етничких група, пословних корпорација и спортских клубова. Исто, стр. 68. 
Национални симболи ${ }^{117}$ имају своју историју као и обликовање националног идентитета. Заправо, национални симболи имају важну улогу у националној идентификацији и сваки народ на свету идентификује се на основу својих националних симбола, и то пре свега: грба, заставе и химне. Важност националних симбола уочава се свуда, на објектима државних институција, униформама државних формација, као што су војска, полиција, царина, на грбовима (државним и градским), али и на спортским теренима и манифестацијама. Под националним симболима се воде ратови и жртвују животи зарад слободе и независности државе.

\subsection{2 Језик}

Језик је један од првих облика људске симболичке активности. Човек се служи језиком да би означио, именовао, појмовно изразио предмете и бића, појаве, који постоје независно од појединца. Уочљива је јасна разлика између језика као „знака“ и језика као „симбола“. Језик, као и религија, битан је елемент ма које културе или цивилизације.

Функција језика је да организује и конструише наш приступ стварности, а све што знамо о стварности посредовано је језиком. Из тога проистиче да различити језици заправо производе различито мапирање стварности. Када Европљанин посматра снежни предео, он види снег. Еским који посматра тај исти призор запазиће у њему много више, јер Ескими за опис снега имају више од 50 речи. Према томе, Еским и Европљанин који стоје један крај другог и

117 Ту спадају очигледни атрибути нација - заставе, химне, параде, монете, престонице, заклетве, народна ношња, фолклорни музеји, ратни споменици, помени мртвим припадницима нације, пасоши, границе - као и њихови скривенији аспекти, на пример врсте националне рекреације, природа, народни јунаци и јунакиње, бајке, облици етикеције, архитектонски стилови, народна радиност, форме урбанистичког уређења, правне процедуре, образовна пракса и војни кодекси - сви они особени обичаји, колективне норме, стилови и начини делања и осећања који важе за све припаднике заједнице историјске културе. Према: Антони Д. Смит, Национални идентитет, Библиотека XX век, Београд, 2010, стр. 124. 
посматрају исти призор опажаће заправо слику која у њиховим главама и њиховим језицима речено̄ представља две сасвим различите стварности. ${ }^{118}$ Лудвиг Витгенштајн је тврдио да: „границе мог језика су границе мог света“, а Фридрих Ниче је описао језик као „затвор“ и уз то је говорио да „истину више стварамо него што је откривамо“.

Језик је данас немогуће посматрати само у оквиру оних научних области које се баве искључиво језичком праксом. Наиме, језик се мора сагледати комплексно и у интеракцији са другим друштвеним категоријама, које су у корпусу различитих научних дисциплина. Језик, али и идеје не само да описују него и обликују стварност, као што смо већ назначили. Ако је стварност, тј. део стварности, примера ради, предмет посматрања студија безбедности у теорији секуритизације безбедност се концептуализује као језички акт. Да би се нешто означило као безбедносна претња, неопходно је да постоји дискурс којим ће се она означити као таква. У овом случају језик је средство које означава одређени безбедносни чин.

Прихватајући да је језик друштвена творевина и према многима „тотални друштвени феномен“, не можемо се не сложити с чињеницом да језик ипак није само производ друштва, него добрим делом и његов креатор, с обзиром на то да је друштво почело успешно да се развија тек усвајањем језика и његовим коришћењем у низу активности. ${ }^{119}$ Једно од најтежих питања модерне мисли гласи: какве везе се успостављају између језика и друштва, језика и мишљења, језика и предметног света? Он има своје унутрашње односе, свој живот и

118 Стварност је шира и дубља од наше појмовне слике о њој, јер има искустава која јесу стварна, али нису изрецива у научним појмовима. Видети: Ђуро Шушњић, Знати и веровати, Чигоја штампа, Београд, 1995.

119 Наука је утврдила да се и животиње служе гласовима и другим сигналима да би се међусобно споразумеле о извесним нагонским стањима, страховима, опасностима, љутњама. Али је биолошка и друштвена еволуција човека, условљена телесном конституцијом и предусловима човека (уз рад и производњу), суштински одвојила човека од његових сродника из животињског света, а посебно у области говора и језика. Животињски говор никада није био у стању да пређе границу емотивног говора и да се уздигне на ниво означавајућег говора. 
релативну самосталност, своје тешко препознатљиве законитости и своје духовне слојеве, своју специфичност, што не значи да је језичко стварање потпуно недокучиво.

Познавање језика (матерњег и других) веома је важно, јер отвара нове перспективе према другачијим начинима сагле́дања одређених појава, односа и процеса. Да би описали, представили неку појаву или процес, неки језици су богатији и располажу са више језичких термина или категорија помоћу којих описују дату појаву. За разлику од њих, „сиромашнији“ језици су ускраћени за ту могућност да раскошно и богато представе предмет о којем се говори дискутује у свим његовим варијететима, а самим тим изазову различите пориве, реакције или представе код човека.

Богатство језика се у великој мери огледа у развијености његових синонимских могућности, као и у његовим изражајним способностима. Или, прецизније речено, у његовој развијености и раскошности у лексичком, морфолошком и семантичком смислу. Познавање језика (матерњег, пре свега) важно је и са аспекта далекосежних ефеката, употребом једне речи у ситуацији када је битно да се установи шта она заправо значи, и за кога, пре него што крене у масовну употребу. Ово може да буде и скупо плаћена лекција из језичке и опште културе. ${ }^{120}$

Људи различитих култура имају потребу да комуницирају једни с другима и морају да пронађу средство за то. Кроз историју су се појављивали језици

${ }^{120}$ Као добра илустрација може послужити пример употребе речи иредента и иредентизам. У међународном праву ови термини означавају покрет за присаједињење матици делова њене легитимне територије које је запосела нека друга држава. Према томе, покрет на Косову који се код нас званично тако именовао пуних седам година (током осамдесетих година прошлог века) може се евентуално тако звати само гледано из угла великоалбанске политике у самој Албанији (иако ни за то нема историјског основа), док из српског угла то може да буде само сепаратизам - како је након тога почело да се зове. Другим речима, један сепаратистички покрет годинама се у очима светске јавности фактички легитимисао тако што је приказиван као ослободилачки покрет - само употребом те једне, али кључне речи: иредентизам. Видети: Ранко Бугарски, Језик од рата до мира, Чигоја штампа, Београд, 1997, стр. 32. 
широко распрострањени и прихваћени за ефикаснију комуникацију међу дипломатама, научницима, пословним људима, као што су: француски, латински или енглески у новијој историји. У овом случају се језик користи као оруђе комуникације, ${ }^{121}$ а не извор идентитета и заједнице. Уколико се појединци или две државе споразумевају, примера ради, на енглеском језику, не значи да су постали англофили или да су прихватили западни начин размишљања. Језик ће вероватније бити прихваћен као језик шире комуникације ако није идентификован с посебном етничком групом, религијом или идеологијом.

Кроз историју се ширење употребе одређеног језика у свету рефлектовало на ширење моћи у свету. Језици који се најшире говоре - енглески, шпански, француски, кинески (мандарински) - били су језици империјалних држава које су активно промовисале употребу језика од стране других. Како се померају центри моћи, тако долази до промене у коришћењу језика. Тако, у другим облицима културе све већа моћ генерише лингвистичку агресивност оних којима је језик те земље матерњи и подстрек за друге који желе да га науче. Моћ језика извире и из његове способности да створи јединствену област размене и комуникације, који доприносе јачању националног идентитета. За

${ }^{121}$ Употреба српског језика у првом столећу после пада српске Деспотовине (1459) достигла је географску распрострањеност каква није забележена ни пре, а вероватно ни касније. Стицајем околности, српски је постао један од дипломатских језика у југоисточној Европи. Њиме су се у међународној преписци служили турски султани, везири, заповедници војски на терену, али и мађарски и румунски владари. Познато је да су се турски званичници из српских крајева, почев од 1396, дописивали са Дубровчанима на српском језику, а од 1420. до средине XVI века султани пишу писма Дубровнику махом на екавском наречју српског језика. Разлози овакве праксе налазе се у чињеницама да је Турска, заузимајући некадашње место српске државе као господара дубровачког залеђа, преузела и знатан део њених функција и њене традиције, а да је на турском двору било много достојанственика пореклом из српских крајева. Свакако је од значаја био и велики углед некадашње српске државе. За време владавине султана Мехмеда II Освајача био је сачињен персијско-арапско-грчкосрпски фразеолошки речник, који је носио наслов Lugat - i farisi, arabi ve rumi ve srb и обухватао шездесетак калиграфски исписаних страница. Према: Павле Ивић, „Књижевни и народни језик код Срба“, Историја српског народа, Друга књига: Доба борби за очување и обнову државе (1371-1537), СКЗ, Београд, 1982, стр. 525. 
двоје људи који не разумеју један другог тешко је рећи да деле исти национални идентитет.

У великој мери, данас су у употреби народни језици, иако постоје и неки изузеци. На пример, где је народни језик нестао, он је често замењиван државним језиком. У Шкотској је практично нестао галски језик, пре свега због наметања енглеског, што је резултовало тиме да касније енглески постане шкотским националним језиком. ${ }^{122}$ Распад СССР-а и крај Хладног рата промовисали су и поново вратили на сцену подмлађене језике који су били потиснути или заборављени. Естонски, литвански, украјински, грузијски и јерменски данас су национални језици независних држава. Азербејџански, киргистански, туркменистански и узбекистански прешли су са ћириличног писма на западно писмо својих турских сродника, док је Таџикистан, у којем се говори персијски језик, усвојио арапско писмо. Примера има још много.

Као средство комуникације, језик је у директној зависности од субјеката који га користе. Диференцирање језика на дијалекте, жаргоне, провинцијализме, професионалне елементе значи да друштвени услови чине битан део, супстрат језичких промена, пошто сваки субјект који користи језик припада некој друштвеној групи. Друштвена организација неког друштва мора да се одрази и на речник, облик, па и на значења, у оквиру одређеног језика. Језици ловачких и пастирских народа морају се разликовати у лексичком, морфолошком и семантичком смислу, исто као што се разликују језици народа који се баве морепловством или језици древних друштава у односу на модерна.

У зависности од потреба и прилика у којима се користи, језик мења своју форму. Тако се језик дипломатије замењује језиком бојног поља у складу са ситуацијом у којој се нађу корисници одређене језичке форме. Језик политике

122 Постоје случајеви где је више од једног језика у употреби званично унутар нације; ово је случај у Квебеку (француски и енглески), Каталонији (каталонски и шпански) и Швајцарској (немачки, француски, италијански и романш, тј. реторомански). Ипак, док је француски у Канади званични (заједно са енглеским), и то не само у Квебеку, званични каталонски статус ограничен је на Каталонију, где је коофицијелни (дели службени статус) са шпанским, који је, опет, једини службени језик на целој територији Шпаније. 
се може посматрати као вид употребе језика који се издваја својом специфичном сврхом, а сврха му је у суштини прагматичке и реторичке природе - обликовање и пропагирање политичких ставова, утицање на мишљење и деловање људи, мењање друштвене свести, афирмација ауторитета власти и слично. Он се веома лако трансформише у језик рата, који као појава постоји веома дуго, али се као предмет проучавања наметнуо тек у новије време, у вези са догађајима као што су дебата о нуклеарном оружју и ратови у Вијетнаму, Заливу или СФР Југославији; најсвежије и у „афричким ратовима“ (тзв. Арапско пролеће) 2011.

Разорно дејство језика у ратном походу прилично је јасно, али размишљања о употреби језика могу се померити ка могућем доприносу језика успостављању и одржавању мира. Језик мира може бити важан састојак сваког мировног решења, било када и било где да је постигнут. И, као што тврди Ранко Бугарски, „мир ће потрајати уколико је подржан одговарајућим вербалним понашањем, а потенцијали језика се морају искористити у сврху постизања и одржавања мира бар онолико колико су злоупотребљени у служби рата“. ${ }^{223}$

\subsection{3 Обичаји}

Део сваке културе чине и обичаји, који се огледају у припремању хране, одевању, васпитању деце, бризи за старе, сексуалној иницијацији, религијским веровањима, друштвеној, политичкој и социјалној организацији итд. На основу обичаја култура указује на метафизичку структуру људског рода, који је у својим битним одредницама јединствен. Уз обичаје долази до изражаја осећајност и страственост једног народа, што указује и на то да човек није само „ratio“, каквим су га од просветитељства наовамо хтели приказати бројни теоретичари.

Како је објашњено у Енциклопедији политичке културе, обичаји или навичаји, тј. неписани закони, регулишу целокупни живот традиционалног друштва, док

\footnotetext{
${ }^{123}$ Ранко Бугарски, Језик од рата до мира, Чигоја штампа, Београд, 1997, стр. 126.
} 
се у модерном друштву налазе у знатно мањем броју и прилично су редуковани. Обичај представља друштвени пропис или норму у којем су у једном неорганизованом колективитету неки дуготрајни, устаљени образац понашања сматра обавезним у одређеним ситуацијама и за чије се непридржавање примењују одговарајуће санкције. Његови основни елементи су: довољно дуго трајање, мала распрострањеност, свест о обавези придржавања и примена санкција у случају непридржавања обичајне диспозиције (императива). ${ }^{124}$

Обичаји се могу објаснити и као искуством стечене навике које су, у време настанка, а у условима стабилне друштвене културе, највише одговарале општим потребама дате друштвене заједнице. Иако настаје институционализацијом навика, обичај, као колективни образац, треба разликовати од навике, као личног искуства. ${ }^{125}$

Постоји широка лествица обичаја који се налазе у разним културама и циљ науке и научника јесте да схвате начин на који се те културе преображавају и диференцирају, различите облике кроз које се изражавају, као и начин на који обичаји разних народа дејствују у животима појединаца који тај народ сачињавају. У контексту дате културе обичаји су смислени уколико доприносе одржавању и јачању друштвене кохезије установљеног поретка. Као један од главних стубова традиције, обичај има велики значај за одржавање културног и друштвеног континуитета, као и за национални (етнички), верски и локални (завичајни) идентитет. Не препоручује се поновна доминација обичајних културних образаца, јер могу да доведу до традиционализма.

Традиционални обичај, посматран широм света, сачињен је од мноштва прецизно описаних понашања, а одлучујућу улогу има у искуству и у веровању, као и врло велику разноврсност коју је у стању да испољи. Погрешно је и крајње поједностављено рећи да обичаји у традиционалном друштву регулишу све, а да у модерном друштву не регулишу више ништа, јер

\footnotetext{
${ }^{124}$ Енциклопедија политичке културе, Савремена администрација, Београд, 1993, стр. 746.

${ }^{125}$ Постоје колективне навике, које се од обичаја разликују по томе што их не прати осећање обавезности и санкција, док их обичај, као друштвени пропис, несумњиво има.
} 
су их заменили право, морал, мода, правила понашања, као диференцирани облици друштвених правила, односно прописа. ${ }^{126}$

Обичаји сигурно нису статичне категорије него су и еволуциони процеси, који подлежу културној реинтерпретацији. Мењају се, јер до промена долази и у друштвеним делатностима, начину живота и вредносним оријентацијама. Најдуже опстају они обичаји који задовољавају неке основне људске потребе и који су подложни функционалној и симболичкој реинтерпретацији, обезбеђују репродукцију појединих облика друштвености.

У политичкој сфери посебан значај има обичајност, схваћена као социјална или чак универзална моралност, уставни обичаји, као нека врста политичких обичаја, међународни, али и други правни обичаји, на пример, узансе као кодификовани пословни обичаји. Међународни обичаји, а поред њих и захтеви човечности и захтеви јавне свести, представљају трајне изворе правила о обавезном понашању у рату. Они обавезују увек и свакога, независно од тога да ли је дата држава потписник неког уговора (конвенције) који треба да се примени или пак није. Дакле, када обавеза не произлази из уговора, односно ако неко питање није уређено уговором, законитост датог понашања се цени у светлу међународног обичаја, човечности и јавне свести. ${ }^{127}$

Својевремено је Џон Дјуи [John Dewey] изјавио да удео који припада обичају при уобличавању понашања појединца, као и у свему оном што је у вези с традиционалним обичајем, исти као однос целокупног речника његовог

${ }^{126}$ Мада се може рећи да су обичаји трајнији и целовитији у традиционалном или неразвијеном него у модерном или развијеном друштву и дуже се одржавају у селу него у граду. Ишчезавају и трансформишу се постепено и уз одређене правилности, а спорије се уобичавају и још спорије изобичавају.

127 У међународном ратном праву, позната је тзв. „Мартенсова клаузула“, која се налази у преамбули Конвениије о законима и обичајима рата на копну, из 1907. године, у којој пише: „Док не буде могао да се прогласи један потпунији зборник закона рата, Високе стране уговорнице сматрају корисним да потврде да, у случајевима који нису предвиђени прописима од њих усвојеним, становништво и учесници у рату остају под заштитом и влашћу начела међународног права онаквим како она произлазе из обичаја установљених међу просвећеним народима, из захтева човечности и из захтева јавне свести.“ 
матерњег језика према оним речима његовог сопственог детињег говора које су прихваћене у говору његове породице. Животна историја сваког појединца јесте, на првоме месту и пре свега, прилагођавање обрасцима и мерилима који се у његовој заједници преносе с колена на колено.

\subsection{4 Ритуали}

Ритуали као стилизоване, програмиране активности и поступци имају за циљ не само да изазову одређене ефекте, већ и да изразе и пренесу одређене културне вредности и веровања. Основна функција ритуала јесте да изрази одређене културне садржаје - претпоставке, вредности и веровања. На тај начин ритуали, стварајући утисак познатог окружења, истовремено доприносе и стварању осећаја сигурности код чланова организације, групе итсл. Ритуали могу и да представљају границу између оних који припадају датој групи, њени су чланови, и оних који то нису.

Као и језик, ритуал је симболички систем заснован на арбитрарним правилима, али и на дубоким, скривеним психолошким и социјалним мотивима, и игра велики број улога у индивидуалном и колективном животу. Он обухвата велики број појава, од конвенционалног и схематизованог понашања животиња и неуротичара, преко магијских и религијских обреда примитивних друштава, церемонија развијених античких цивилизација, манија, шаманистичких сеанси, црквених литургија, политичких парада, иницијација у тајна друштва, до разних других славља и светковина широм друштва. Познато је да је убиство део ритуала иницијације у различитим криминалним и секташким заједницама, а исти механизам омогућава да и у привидно легитимним заједницама, као што су државе, у периодима кризе, моралног суноврата и системске изолације, убиство постане „прихватљив чин“.

Постоји више дефиниција ритуала, али је могуће навести основне карактеристике које се помињу у свим тумачењима овог културног феномена. То су: симболички израз човека и друштва; стандардизована, стилизована, репетитивна радња, која се односи на „свете ствари“, тј. на референцијалну 
раван изван и изнад свакодневне сфере егзистенције, појава која изражава емоције, веровања и ставове друштва; акт који контролише веровања, емоције и ставове друштва, радња која утиче на разрешење друштвених конфликата и јачање веза солидарности и друштвене кохезије, чиме активно учествују у потврђивању поретка. ${ }^{128}$

Свеобухватни смисао ритуала се највише испољава у оквиру политике. И поред већ распрострањеног мишљења да је ритуал застарео, превазиђени облик понашања, непримерен научно-технолошкој цивилизацији и политици као прагматичној, чак тривијалној делатности, постоје и мишљења која је посматрају у ширем антрополошком и културном контексту. С тога гледишта, ритуализам се посматра као један од универзалних облика приказивања и доживљавања друштвености, а политика као природно тло на којем се он развија.

На схватање политичких ритуала као изданка древних, религијских ритуала, указао је Емил Диркем, а његову теорију је у основним цртама прихватила функционалистичка антрополошко-социолошка школа. ${ }^{129}$ Ова теорија ставља у први план улогу ритуала у успостављању идејног и моралног јединства одређене заједнице. То јединство настаје и потврђује се у најинтензивнијем

${ }^{128}$ Енциклопедија политичке културе, Савремена администрација, Београд, 1993, стр. 1018.

129 Диркем је увео у теорију поделу друштвеног искуства на „свето“ и „профано“, постављајући их као два неспојива и апсолутно различита домена. Увођењем појма свето̄г постиже се двострука теоријска намера: открива се органска повезаност између светковине и религије, и порекло свето̄г у друштву, што светковину одређује као прворазредну друштвену појаву. Диркем је управо у религији „примитивних“ народа открио елементарни образац који се понавља и у сложеним друштвима. Тврдио је да у примитивним религијама ритуал има примат над веровањем. Он је ритуале и светковине ставио у са́мо средиште стварања религијске идеје, сматрајући да превасходно у тренуцима свечаног окупљања, кроз обредне радње и интензивно осећање припадности групи, друштво ствара религијску идеју. Религија тако није постојала да би спасавала душе и одговарала на етичке потребе појединаца, већ ради одржања и добробити друштва. Диркем развија теорију порекла религије по којој ритуали и светковине представљају генераторе развоја осталих облика религијског мишљења и веровања. Дистинкција између два супротстављена домена реалности - свето̄г и профано̄г - за Диркема је априорни концепт сваког размишљања о светковини. 
тренутку друштвеног живота, „колективној узаврелости“, када се све друштвене енергије концентришу у једној тачки.

У литератури о ритуалима и светковинама, посебно оним секуларне природе, често се наилази на мишљење да се појам ритуала мора ближе одредити појмовима секуларно̄г и религијско̄г, да би се тачно одредио домен на који се односи. Из тога би произлазило да су појмови ритуал и секуларно̄ неспојиви и да се ритуал мора посматрати само у религијском тумачењу. То значи да су појмови свето̄г и религијско̄г идентични. Искуство, међутим, указује да се светковине и ритуали не могу стриктно везивати за религију, нити свето̄ са религијом или профано̄ са секуларним. Свето̄ не треба идентификовати са религијским, већ га ваља схватити као трансцендентни објекат религијског или секуларног порекла са којим светковина нужно комуницира.

Обележја политичког ритуала израстају из религијске праосновице ритуализма. Пошто је политички ритуал ситуиран у секуларном домену, неизоставно се поставља питање значења свето̄г у њему. Између религијског и секуларног идеала разлика је идеолошка, а не социолошка; први се односи на онај свет, а други на овај, али оба истичу везе између човека и одређених духовних, моралних, економских или политичких вредности као апсолутних ауторитета.

\subsection{5 Вредности}

Постоји размишљање по којем уласком у свет вредности и потреба откривамо онај прави, својеврсни свет човека, у којем „човек рефлектује делимично своју културу, а делимично свој сопствени стил живота“. ${ }^{130}$ То је уједно и сфера у коју је најтеже продрети, тако да су дуго и биле само предмет филозофских размишљања. Социјална психологија и антропологија значајно су допринеле да се вредности адекватно проучавају и помоћу расположивих научних средстава,

${ }^{130}$ Gordon Allport, Becoming, Basic Considerations for a Psychology of Personality, Yale University Press, New Haven, 1995; према: Загорка Голубовић, Антропологија, Службени гласник, Београд, 2007. 
а обогатиле су и теорију о људском понашању, социјалној акцији, као и теорију личности.

Историја вредности идентична је са историјом културе. У друштвеном начину живљења вредности се никада не јављају изоловано, већ у одређеном реду, за који је карактеристичан критеријум избора ствари, знакова и понашања. Вредности могу означити одређене тековине помоћу којих друштво решава своје проблеме и задовољава своје потребе, тј. дефинише смисао свог постојања, па су вредности као такве елементи друштвено-културног система. Такође могу представљати и стандарде помоћу којих друштво препоручује шта је од постојећих и могућих тековина пожељније са становишта потреба и интереса друштва, те као такве представљају елемент културног система у ужем смислу (у смислу нормативног система). Вредности представљају и одређене оријентације које индивидуе током живота формирају, самостално или као део групе/заједнице и уз помоћ којих се догађају процеси интеграције (односно дезинтеграције).

За вредности смо већ рекли да су базична, релативно стабилна веровања, настала као резултат социјализације, под утицајем индивидуалног искуства, те друштвених и културних фактора, а који на индивидуалном нивоу утичу на ставове и понашања. Оне су такође, као што смо видели, и основа за друштвене норме које представљају друштвена правила или упутства за одређење прикладног понашања у одређеним ситуацијама. Свако непридржавање прописаних норми доноси санкције различите оштрине, а свакако најжешће за кршење обичајних норми и закона.

Свако друштво је кроз историју било одређено културним и наслеђем цивилизације. Тако је и данас. Такође се свако друштво одређује и вредностима у настајању, дакле оним које се тек уводе и успостављају. Дакле, уочавамо вредности које су достигнуће друштвене и културне историје и вредности које су незаобилазни чинилац свакодневног људског живота. Између њих често настају и спорови.

Свака историјска епоха и заједница успостављају систем вредности полазећи од себе и доминирајућих друштвених односа, облика рада и производње. Поред 
већ поменутих подела вредности (поглавље 2.2.2), постоје, дакле, и старе вредности, непосредне вредности, нове вредности, осведочене вредности, фундаменталне вредности, универзалне (трајне) вредности. Ова лепеза система вредности указује на сложеност говора о вредностима у друштвеноисторијском контексту.

Колико је све то сложено, видимо и из чињенице да човек није искључиво биће непосредних потреба. Он живи, али и памти, антиципира, креће се у сфери вредности и циљева. Тако је и пољски филозоф Карел Косик говорио да „људска стварност није само продукција новога, већ је репродукција прошлости“. У структуру друштва и његову културу уграђене су вредности - и прошле и садашње и неке које су тек у наговештају.

Вредности су такав елемент културе који одређује оријентацију у делатном животу људских група и индивидуа, и служи као критеријум селекције између постојећих и могућих алтернатива за задовољавање потреба и тада вредности могу имати и позитиван и негативан карактер. Наиме, оријентација и друштава и индивидуа може бити двострука: позитивна (са креативним набојем) и негативна (са елементима деструкције).

\section{4 Основи националне културе}

\subsection{1 Појам и значење}

У уводном делу смо видели да се национална култура може дефинисати као скуп претпоставки, веровања и вредности које деле припадници једне националне заједнице и који битно одређују њихово разумевање света, као и понашање у њему. ${ }^{131}$ Наведене претпоставке, вредности и норме углавном су

${ }^{131}$ Н. Јанићијевић: „Глобализација и националне културе земаља у транзицији: конвергенција или дивергенција?“, Пословна политика, год. 31, бр. 7-8, 2002. 
подсвесног карактера и одређују замисао људске природе, однос према природи, као и односе између људи.

Да бисмо јасније разумели и одредили оквир третирања националне културе у овом раду, морамо поћи од чињенице да постоје различите културне групе у различитим географским регионима и да свака поседује заједничко културно памћење и заједнички систем симбола, што, опет, не значи аутоматски да је култура исто што и нација. Стога, дефинисање културе на националном нивоу није чест приступ антрополошких и наука о култури. Нације су релативно нова појава и не морају неминовно да чине хомогену културу. Такође, појаве као што су национализам, глобализација, миграције и сличне, у савременим друштвима постају снажније и са јачим утицајима, јер, између осталог, могу чак и ојачати културну разноврсност у оквиру једне исте земље.

Ипак, у литератури о менаџменту концепт националне културе је солидно успостављен и широко признат. Холандски истраживач Хотстеде [Geert Hotstede] свестан је проблема перспективе ширег аспекта када се говори о култури, али у својим истраживачким радовима наводи снаге које интегришу (уцелињују), као што су: језик, национални образовни систем, национална армија, национални политички систем, национална заступљеност у спортским манифестацијама и догађајима, тржиште домаћих производа и услуга са одређеним вештинама и слично. Све заједно може довести до могућности концептуализације културе на националном нивоу, јер су детерминанте које имају утицај на „програмирање ума“ упоредиве, с обзиром на то да људи у оквиру једне земље мисле и осећају на сличан начин.

Хотстеде је, иначе, дефинисао националну културу као „колективно програмирање ума које разликује једну групу људи од друге“. ${ }^{132}$ Он је предложио да се људи деле према колективном националном карактеру, који представља њихово културно ментално програмирање. Ово ментално програмирање обухвата вредности, уверења, претпоставке, очекивања,

\footnotetext{
${ }^{132}$ Geert Hotstede, „National Cultures in Four Dimensions“, International Studies of Management and Organization, 1983.
} 
перцепције и понашања. Да би се различите културе тумачиле, потребно је посегнути за различитим димензијама појединачних култура, како би се њиховим поређењем пронашле сличности и разлике, односно створила матрица кроз коју би се преламале особине култура различитих народа. ${ }^{133}$

Неки научници су подржали Хотстедеа и предложили оквир за проучавање културе на националном нивоу. Они су идентификовали основне друштвене проблеме који ангажују све људе без обзира на њихову националну припадност. Разлике међу земљама настају јер свака национална култура има другачији приступ како се прилагођава идентификованим друштвеним питањима или проблемима који су од значаја за све. Поред тога, Стенкамп [Jan-Benedict EM Steenkamp] сматра да се култура валидно може појмовно замислити на националном нивоу, ако постоји неки облик заједнице у оквиру нације са значајним разликама у односу на припаднике других етничких заједница. $^{134}$

Уважавајући и могућу тензију између појмова културе уопште и националне културе, треба истаћи да се било које стваралаштво које називамо културним

${ }^{133}$ Хотстеде је био пионир у развоју националне културне димензије, кроз своја истраживања у локалним јединицама корпорације ИБМ у више од 50 земаља света. С тим у вези Хотстеде је открио да култура има четири димензије помоћу којих се могу објаснити начини на које се људи из различитих култура понашају баш тако како се понашају. То би биле следеће димензије: дистанца моћи, избегавање несигурности, индивидуализам и принцип мушкост/женскост. У међувремену је у оквир анализе увео и пету димензију, која представља дугорочну оријентацију, а подразумева или прихватање дугогодишњих или краткорочних друштвених вредности. Слично су други истраживачи подржали ова Хотстедеова истраживања или су као полазне тачке у сопственим истраживањима узели идентификовање заједничких друштвених проблема, као што су: однос према власти, концепт сопства (однос између појединца и друштва), појединачни концепти мушкости и женскости и начин решавања конфликта. Видети: Shalom H. Schwartz, „Are there universal aspects in the content and structure of values?“, Journal of Social Issues (1994), 50, pp. 19-45; и F. Trompenaars, „Resolving International Conflict Culture and Business Strategy“, Business Strategy Review, 1996, Volume 7, Issue 3, pp. 51-68.

134 Jan-Benedict EM Steenkamp, „The role of national culture in international marketing research“, International Marketing Review, 2001, vol. 18, iss. 1, pp. 30-44. 
сматра отвореним за културну комуникацију најширих размера, али истовремено уколико је у питању засебна култура, у њој се може распознати оригиналност у форми и садржају као нешто што исказује дух људи и народа међу другим људима и другим народима.

У том смислу национална култура представља оквир стваралаштва и деловања који се не може по обиму и садржају појма нивелисати на општу културу. На основу таквог разумевања националне културе може се говорити о њеном утемељењу у одређеним цивилизацијским парадигмама, њеној трајности на основу специфичних културних образаца и актуелности у погледу особености искустава и начина живота народа на одређеном простору.

Као што смо у уводном делу већ нагласили, издвајају се три суштинска елемента што обележавају поље у оквиру којег се може разматрати култура, а самим тим и национална култура. На тај начин се ближе одређују не само утемељени процеси који је стварају, већ и процеси који ремете њен поредак и у извесном смислу се свесно намећу да би се започела тзв. модернизација и достигло толико жељено приближавање модерном друштву. Та три елемента су: промена, традиција и идентитет. Овим елементима се бавимо у тексту који следи.

\subsection{2 Традиција}

Традиција је сложена категорија која има своја социолошка, културолошка, антрополошка, психолошка, религијска, историјска, естетска, политиколошка, филозофска и бројна друга одређења. Може се рећи да без традиције не само што не постоји ниједна култура у историји човечанства, већ се без ње не може претпоставити опстанак ниједне људске заједнице.

Термин „традиција“ потиче од латинске речи traditio, у значењу: предање, преношење с колена на колено, усмено ширење прича, порука, веровања, обичаја, а може се објаснити као процес преношења, предавања и одржавања идеја, вредности, начела образаца модела, усмено и писмено с генерације на 
генерацију. ${ }^{135}$ Дакле, оно што се сматра вредним из целокупне историје једног народа. Она је и скуп вредности идеја, норми, обичаја који су садржани у „историјском памћењу“ - културном идентитету појединаца, група, народа и човечанства. Традиција настаје усменим, митолошким и укупним фолклорним стваралаштвом народа и стога се основано говори о митолошкој, легендарној, епској, фолклорној, етничкој и историјској традицији. Једнако се говори и о уметничкој традицији, под којом се најчешће подразумева наслеђивање старих класичних стилова, израза, мотива, техника, материјала.

Међутим, како је нагласио Рејмонд Вилијамс, „традиција се у енглеском језику усталила као ознака за општи процес преношења на следећу генерацију, али је задржала јаку, понекад и доминантну конотацију нечега што треба поштовати и према чему постоји одређена обавеза“. ${ }^{136}$ Код овог тумачења традиције издвајају се и неки елементи као што су: активан однос, свестан избор, процена и приписивање веће вредности одређеним елементима међу многим који се затичу у акумулативном процесу преношења с генерације на генерацију.

Традиција се огледа у различитим сегментима живота и рада једне заједнице или скупине људи. Она може да има свој религијски карактер, па за религијску традицију сматрамо да обухвата историју свих познатих религија и религијских заједница, укупно теолошко наслеђе и верску праксу. На одређени начин традиција утиче на психологију, менталитет и начин живота појединаца, група, народа и нација. Она се не преноси само говором (усмено или писмено), већ и начином понашања, начином живота. У свим познатим психолошким школама посебан значај се придаје утицају традиције на развој личности и друштва. Психоаналитички појам колективно несвесно заснива се на појму традиције, као што је и случај са појмом архетипа.

У правним одредницама под појмом традиције подразумевају се облици преношења имовине од једног власника на другог. Установљена у римском

\footnotetext{
${ }^{135}$ Антоњина Клосковска, Социологија културе, Чигоја, Београд, 2001.

${ }^{136}$ Raymond Wiliams, Keywords. Vocabulary of Culture and Society, Revised edition, New York: Oxford University Press, 1985, стр. 318; према:Марија Тодорова, Имагинарни Балкан, Библиотека XX век, Београд, 2006, стр. 23.
} 
праву, она је могла означити преношење самог предмета, али је имала и симболичко значење. Са развојем савремених друштава и развојем политичких наука, под традицијом се подразумевају одређени начин организације друштва, деловања органа власти и других субјеката политичког система, укупни систем мишљења, као и поглед на свет и понашање политичких партија и институција. Традиција постаје ознака државе која се заснива на традиционалним концепцијама и систему вредности који одређују различите системе владавине. Филозофско-социолошки приступ појму традиције претпоставља такво схватање традиције које обухвата целокупност идеја облика мишљења, обичаја, установа и института, укупну духовну баштину човечанства. У овим разматрањима садржана су сазнања да се ауторитет традиције не заснива само на дуготрајном понављању понашања и постепеном привикавању на одређене друштвене захтеве већ и да се извор традиције налази у човековој онтолошкој структури, што указује да је традиција један од неопходних услова човековог живота. Стога је потреба за традицијом у одређеној мери насушна људска потреба, за коју се каже и да „крчи себи пут до људских срца тиме што их у исти мах ослобађа и заробљава“. У основним филозофским одредницама налазе се и она значења која говоре о традицији као универзалној историјскокултурној појави која омогућава човеково трајање у времену и одређеном социјалном простору.

Позитивне функције традиције исказују се не само у одржавању стварних, трајних и универзалних културних вредности већ и у томе што је традиција присутна у развоју и напретку култура и представља неотуђив део континуитета сваке националне културе. У разноврсним облицима савремене културе преносе се транспоноване изворне културне и преобликоване вредности и обележја која се показују као садржај фолклора, религије и начина живота сваке конкретне групе (народа).

Традиција која се посматра као „света“ и „недодирљива“ не може се вредновати. Она мора да се посматра као битна претпоставка за рађање нове вредности. Трансформација вредности се мора одвијати тако да се нове вредности афирмишу као стваралаштво које уверљиво замењује наслеђено̄. 
При том унутрашња потреба стваралаштва захтева испитивање свих вредности из прошлости као креативног потенцијала које би требало да буде стваралачки настављен и критички оцењен. Хуманистички смисао стваралаштва, оног највреднијег и најпостојанијег, омогућава успостављање континуитета, који је једна од најбитнијих претпоставки за коегзистенцију целокупног стваралаштва, и оног из прошлости и оног из савремености.

Појава нових вредности не сме да искључи потребу осавремењивања и живог присуства највредније стваралачке праксе и значајних културних остварења из прошлости. Сучељавање традиције и нових вредности мора поћи од претпоставке да традиција не постоји као непроменљива константа, а ни нове вредности као коначне и довршене.

Националне и културне особености неопходно је идентификовати, уважавати и протумачити, али не и пренаглашавати и безразложно глорификовати. Уколико се опсесивно везујемо за традицију, постоји могућност да нас готово магнетском снагом повуче ка традиционализму. С друге стране, уколико се потискује духовна меморија, стварају се услови за настајање митова и легенди. Мистификовање и потискивање прошлости, може у неком тренутку васкрснути у неком потпуно искривљеном облику. Или се може трансформисати у процес који је Ерик Хобсбом назвао „измишљање традиције“. ${ }^{137}$

Прецењивање националног „бића““ и националне културе нарочито је опасно кад се јавља као разлог супротстављања другој нацији и другој националној култури. Када се овај дестабилизован систем вредности „оклизне“ до теорије „крви и тла““ и до императивног затварања у сопствене границе, готово је немогуће очекивати присуство било које традиције, сем оне која помаже идеолошку ретроградност и духовни анахронизам. Традиција се не може ни прећуткивати, посебно ако нисмо спремни да је протумачимо и да се суочимо са њом.

С друге стране, традиционална култура може значајно допринети развоју, што најбоље показује брз раст јапанске економије педесетих година XX века, или

${ }^{137}$ Ерик Хобсбом, Теренс Рејнџер (ур.), Измииљање традищије, Библиотека ХХ век, Београд, 2002. 
традиционална медицина када су у питању источњачке културе и народи такође у другој половини XX века.

Сви облици развоја подразумевају известан степен модернизације, што може бити дестабилизујуће за људе у традиционалним друштвима. Потрага за идентитетом је важан проблем у савременом животу. У нормалним околностима није проблем у традиционалним друштвима, која су регулисана основним нормама и стабилним традицијама и чији чланови добијају свој осећај идентитета са улогама које им се приписују, али изненада може постати акутан. То се обично дешава када се традиционална друштвена структура распада или је озбиљно доведена у питање, у тренуцима када се друштво мора носити са изазовима модернизације.

Тај проблем је искусило јапанско друштво када су Јапанци одлучили да се модернизују у другој половини $\mathrm{XX}$ века. ${ }^{138}$ Одржавање основних социјалних улога, као и разлике у вези са њима, исконски су значајни у хијерархијском друштву Јапана. Као напредно савремено друштво, истичу се управо по томе што су ипак успели да одрже већину својих традиција. Јапан је успешно модернизовао своје друштво уз задржавање традиционалних норми и главних улога - основне улоге у породици, непосредним групама, радноме месту, као и ширем друштву - што све пружа Јапанцима снажан осећај личног и групног идентитета. Како су то учинили? То су успели кроз разумну мешавину модернизације и традиције. Одржавање традиције током развојног процеса од суштинског је значаја за успешну модернизацију, управо зато што традиција даје неопходни културни легитимитет новим и иновационим елементима који се уводе у друштво.

\subsection{3 Промена}

Свака култура, свако доба искоришћавају само неколико од великог броја могућности. Промене могу бити веома узнемирујуће и повлачити за собом

138 Mervyn Claxton, „Cultural traditions: An Important Neglected Development Resource for Countries of the South“. Видети: www.normangirvan.info/tag/mervyn-claxton/ 
велике губитке, али то је последица тешкоћа коју доноси сама промена. Чињеница је и да су наше време и одређене земље нашли једини могући покретач којим се људски живот може руководити. Промене су у једном друштву - то се не сме заборавити - са свим својим тешкоћама, неизбежне. Страхови који прате промене, чак и веома незнатне промене, често су неосновани.

Цивилизације се могу мењати много коренитије но што је иједна људска власт икад хтела или маштала да их измени а да и даље остану потпуно способне за живот. Мање промене које данас изазивају толико негодовање, као што су пораст броја развода, слабљење утицаја цркве у урбаним срединама, неке нове слободе које се промовишу у друштву, али и многе друге, могле би бити веома радо прихваћене у неком незнатно другачијем обрасцу културе. Постајући традиционалне, те новине могу добијати исто богатство садржаја, исти значај и вредност које су старији обрасци имали у другим нараштајима. Традиција и иновација нису одвојени ступњеви у друштвено-историјском развоју који временски смењују један други, већ превасходно културни чиниоци који се узајамно преплићу и прожимају.

Култура се схвата пре као динамичка него статичка, као нешто што се константно мења током времена док апсорбује спољне утицаје и прилагођава се промени окружења и технологије. Култура, дакле, има веома значајну функцију комуникације и опажа се да се локалне културе у последње време брзо мењају услед брзог развоја у комуникацији и транспортним технологијама и интензивнијег кретања људи и идеја између култура. Већина култура је апсорбовала стране утицаје током времена захваљујући трговини, миграцији, колонизацији или прозелитизму. Последњих година масовни медији и велике миграције становништва преко континената виде културу како прима нове утицаје бржим темпом. Већ је одавно познат утицај америчких медија и брзе хране на Истоку, док се у исто време аспекти источњачке културе апсорбују у западну, попут здравственог система из Кине (tai chi) и Индије (јога), као, уосталом, и храна из целог света. 


\subsection{4 Идентитет/различитост}

Појам идентитета, као што је познато, има многобројне ликове. Користи се у различитим околностима, као што су анализа изградње личности детета или одбрамбени став народа током ратних сукоба. Да би се на прави начин схватио идентитет, потребно је покренути размишљања о процесима који уређују његову историјску изградњу, доводе у сумњу, производе губитак или поновно присвајање/рађање.

Идентитет [лат. identitas, од idem, „исто“], као што смо представили већ у уводним деловима, најчешће подразумева скуп и континуитет суштинских својстава којима се нека људска група или јединка дефинишу наспрам других обезбеђујући тако своју „самоистоветност“. То је, дакле, осећање припадности датом колективу, односно свест о сопственој личности. При томе је идентитет увек сложен од низа компоненти, ${ }^{139}$ јер се социјални простор конституише укрштањем и преклапањем различитих друштвених група, сачињених од исто тако вишестрано оријентисаних појединаца.

Разноврсност можемо уочити код сваке индивидуе која може бити родитељ и/или дете, шеф и/или радник, католик или православац, а сваки од предочених идентитета мање је или више релевантан у различитим врстама контекста. Исто важи и за државе. Тако, на пример, идентитет Уједињеног Краљевства је вишеструко изражен: као демократска држава, као део Европе, као неко ко је у посебном односу са САД, као лидер Комонвелта, као свеобухватан ентитет који се састоји од Енглеске, Велса, Шкотске и Северне Ирске, или као некадашња империјална сила. Сваки од ових идентитета може се довести у везу са различитим облицима праксе, при чему они такође могу бити међусобно сукобљени. Идентитет УК као чланице ЕУ понекад се дефинише у

\footnotetext{
139 Ове компоненте могу се легитимно посматрати и као различите врсте идентитета, па тако говоримо о етничком, националном, културном, конфесионалном, социјалном, регионалном и другим врстама или подврстама идентитета - од полног и узрасног до професионалног и политичког.
} 
супротности са њеним идентитетом суверене државе, или пак у супротности са њеним посебним односом са САД.

Идентитет се користи на разне начине и односи се на скуп других категорија, укључујући дискурс, моћ, интересе, институције, психологију и метод. Поред разноврсности, неке од одлика идентитета су и различитост, флуидност, изграђеност. Оно око чега се аналитичари (посебно критичке оријентације) начелно слажу јесте да идентитет постоји у односу на (другог) - идеја која је често обухваћена појмом различитости. Наиме, тај однос може да изгледа другачије у различитим друштвеним скупинама, однос родитеља и деце другачије је постављен у друштвима у којима доминирају шире породице, а другачије у онима у којима преовладавају уже породице, или породице са самохраним родитељима. Идентитети се, дакле, дефинишу према релационом својству (односу), а оно је контекстуално одређено. Међутим, чак и у оквиру контекста идентитети не морају бити фиксни, већ могу да се преплићу са другим идентитетима.

Идентитет није дефинисан само у интеракцији са опасном другом страном. Као средство за редефинисање идентитета који су конституисани према потпуној и великој разлици јавља се дијалог. Хабермас [Jürgen Habermas] је истраживао дијалог као форму комуникативне активности и рационалности помоћу које контекстуално упућени актери теже ка универзалном консензусу заснованом на снази бољег аргумента.

У пракси су процеси дијалога дефинисани мање према тежњи ка универзалној сагласности, а више према покушају да се поставимо изнад апсолутног односа између идентитета и разлике - основе конфликта - и усмеримо према неком облику заједничког идентитета и језика који би учинио разговор - као супротност сукобљавању - могућим. ${ }^{140}$ У том смислу су се развијали и одређени политички концепти и решења за превазилажење несугласица и

\footnotetext{
140 Крајем Хладног рата европски дијалог је установио грађане једне целовите и слободне Европе, насупрот раздвојеним хладноратовским идентитетима у подељеној Европи. Подељена друштва која су излазила из конфликта, такође су тражила неку врсту заједничког идентитета.
} 
конфликата који произлазе из културне различитости и који су видљиви у пракси, а о којима смо већ нешто рекли.

У претходним излагањима већ смо нагласили да је национални идентитет (нарочито у одређеним историјским периодима) један од најважнијих, али и најпротивречнијих испољавања идентитета. На себи својствен начин национални идентитет условљава развој и испољавања осталих облика идентитета. Национални идентитет се може представити као свест о укупном „јаству“, припадности некој националној и културној скупини. Везује се уз формирање нација-држава поштујући вестфалски поредак и територијални темељ идентитета. Саткан је од многобројних других идентитета, а у мноштву других превагу има религијски идентитет, који је често био разликован од других, па се у државама, уз језик, обичаје и територију, узимао као диференцирајући у конституисању нације.

Веза између идентитета и појма културе развија се на један променљив, флуидан и пулсирајући начин. Идентитети се могу стварати, мењати, прелазити из једног облика у други, нестајати, кроз културе и супкултуре којима људи припадају или у којима учествују.

Постоје и мишљења која истичу да се идентитет темељи на култури, али да није једноставно њен производ. Тако, Стивен Фрош [Stephen Frosh] овај однос представља на следећи начин: „Новије социолошке и психолошке теорије истакле су да је 'идентитет' неке особе заправо нешто вишеструко и потенцијално флуидно, што настаје искуством и што је језички кодирано. Развијајући свој идентитет, људи полазе од културално расположивих ресурса у својим непосредним друштвеним мрежама и у друштву као целини. Зато је процес изградње идентитета процес на који дубоко утичу противречности и прилике социо-културне околине која их окружује.“141

Сама дефиниција културног идентитета треба да обухвати и постојање заједничких културних одлика које симболички омеђују друштвену - у овом случају националну - групу кроз националну културу и национални идентитет.

\footnotetext{
${ }^{141}$ Stephen Frosh, Identity Crisis: Modernity, Psychoanalysis, and the Self, Routledge, London, 1991.
} 
У те културне одлике, као што смо већ поменули, спадају бројни елементи, од језика па до националних симбола, од културне традиције до националне уметности. Као што је познато, културни идентитет обухвата: место, род, порекло/расу, историју, националност, сексуалну опредељеност, религијска веровања и етницитет.

\section{5 Национална култура као национални и јавни интерес}

Култура утиче на интересе на два основна начина: она може да регулише интересе, или може да их конституише. Када култура регулише интересе, она ради углавном на исти начин као правила игре, диктирајући који потези могу, а који не могу да се повуку, која тактика може, а која не може да буде примењена. Њени ефекти су такође слични начину на који калкулације трошкова и добити управљају економским понашањем тржишта. У случају културе, међутим, трошкови и добити почивају на нормама и принципима на које се актери ослањају у одлучивању шта треба да се уради, а шта не. ${ }^{142}$ На тај начин културалне инструкције усмеравају актере у одређеним правцима, чак и када би актери имали користи од тога што не поступају по овим усмерењима.

Национални интереси се генерално могу посматрати као вредности и циљеви који су усмерени према развоју националне заједнице и у тесној су вези са националном безбедношћу. ${ }^{143}$ При том национални интереси представљају

\footnotetext{
${ }^{142}$ На пример, за норме људских права се каже да спречавају владе у злоупотребама њихових грађана чак и када би таква злоупотреба помогла владама да уклоне своје политичке опоненте. Или се за транснационалне културалне табуе каже да спречавају произвођаче оружја у производњи експлозивне муниције у XIX веку, или спречавају велике силе у коришћењу хемијског оружја од Првог светског рата. Видети: Amir Pasic, „Culture, Identity and Security: An Overview“, на: http//www.humansecurity.com/documents/RBF_culture idsecurity.pdf

${ }^{143}$ Синиша Таталовић, Национална и међународна сигурност, Политичка култура, Загреб, 2006.
} 
јасно одређене намере државе, на основу којих се одређују циљеви и начини развоја националне заједнице, док национална безбедност представља организовани приступ државе с циљем њихове заштите, односно механизам за њихово остварење. Такво одређење националних интереса указује да они имају своју унутрашњу и спољашњу димензију што омогућава њихово посматрање с два аспекта.

Уколико се посматра унутрашња димензија, онда је реч о јавним интересима које у одређеној мери треба разликовати од националних интереса, посматраних стриктно у ужем смислу. Јавни интерес представља интерес свих грађана. У литератури појам јавни интерес се најчешће налази под називом „општи интерес“, под којим се подразумевају они интереси који су садржински највише везани за добробит заједнице. Јавни интереси, према томе, везани су за унутрашње благостање држава, док су национални интереси у ужем смислу усмерени према споља, а одређени су као видљиве потребе и тежње једне државе у односу на друге суверене државе које сачињавају њено међународно окружење. Такође, национални и јавни интерес могу се разумети и као нешто што има националну и репрезентативну улогу у откривању, стварању, истраживању, проучавању, представљању, ширењу и очувању националних културних вредности.

Унутрашњем државном благостању доприносе: висок степен развоја, висока стопа запослености, висок животни стандард и слични чиниоци, што је и гаранција националне безбедности. Те су категорије и извор националне моћи државе, која се приказује у њеном богатству, природним ресурсима, производним капацитетима, радној снази, трговини итсл.

Национална култура може да дефинише, тј. конституише интересе описивањем тога чему вреди тежити, а шта треба да се избегава. Дакле, утврдити о чему је реч, која је сврха, који циљеви и које се понашање очекује од учесника/актера неког односа, која се добробит очекује, како ће се развијати и које се претње могу очекивати да наруше или угрозе актере. У складу са фундаменталном забринутошћу за безбедност, различити типови држава, са разноликим културним наслеђем, одређују своје интересе на различите начине. 
Државе са сличним културама и институцијама често имају и заједничке интересе. Једна демократска држава има пуно тога заједничког са другим демократским државама и зато међусобно углавном и не долазе у сукоб. Период након Хладног рата карактеристичан је управо по томе да државе своје интересе одређују цивилизацијским појмовима, како је уочио Хантингтон. Такође је приметио да сарађују и улазе у савез са државама са сличном или заједничком културом, а чешће су у сукобу са земљама друге културе. Наравно, ни то није увек правило.

\subsection{1 Артикулација вредности}

Појам интереса укључује у себе различите вредности, идеје и ставове, услед чега долази до превазилажења дуализма између концепта интереса, са једне стране, и вредности и идеја, са друге стране. У теоријским размишљањима и претпоставкама о односу интереса и вредности, већ је превазиђено схватање по којем се они тумаче као синоними. Може се рећи да су вредности општија и теоријски плоднија категорија и да се на њима заснивају интереси, који у вредностима траже мерило које ће указати на то шта треба изабрати, а шта избегавати.

Национална култура представљена као национални интерес има активан однос према националним вредностима. Она твори темеље за задовољавање основних потреба свих грађана и државе у целини, укључујући самоочување, интегритет, економску и правну сигурност, благостање и безбедност на свим нивоима.

\subsection{2 Перцепција добробити}

Питање учешћа у културним активностима и упознавања са садржајем културе, на неки начин, може бити повезано и са благостањем и добробити појединца и читаве заједнице. Активан животни век појединца и читаве популације у једном друштву може се објаснити не само социо-демографским карактеристикама већ и разликама у коришћењу слободног времена и учешћу у 
потрошњи одређених облика културног стваралаштва. Одређена истраживања чак и потврђују идеју да постоји чврста веза између културног учешћа да би се преживело, при чему учешће у културним активностима и потрошња културних добара могу бити повезани и са друштвеним капиталом. Друштвени капитал се односи на капацитете појединаца и њихову способност да обезбеде погодности кроз припадност мрежама и другим друштвеним структурама.

Култура у том случају представља инструмент који промовише кохезију кроз стварање заједничког језика, на тај начин припремајући амбијент за социјално вођен развој људских потенцијала, стварање и/или регенерацију друштвеног ткива. Такође, генерише систематски могућности за друштвено умрежавање и, уопште, оптимално управљање акумулацијом процеса за друге кључне нематеријалне имовине, као што су друштвени капитал са последичном користи у смислу друштвеног поретка и кохезије.

Учешће у културним активностима и потрошња културних добара успоставља услове да се побољшају материјални и нематеријални облици културног капитала, учешће у њиховој потрошњи, а све представља повод за изградњу и стварање активности умрежавања. На тај начин граде се тесне везе између појединаца и група, и пружају извесне погодности, као што су повећање нивоа добробити свих учесника у заједници.

\subsection{3 Перцепција развоја и угрожености}

У западним друштвима у другој половини XX века култура је постала посебно истраживачко поље везано за процесе развоја, али и утврђивање степена угрожености појединих актера друштвеног живота. Инвестиције у културну инфраструктуру, активности и унапређење културне политике обезбеђују бенефиције на социјалном и економском нивоу и представљају једно од основних средстава реновирања и унапређења политика градова. Дефиниција стратегија развоја усмерена на културна добра посматра се као приоритет и као 
брз начин да се повећа вредност градских и регионалних подручја, јер они имају и највише утицаја на све друштвене актере. ${ }^{144}$

Дефинисање културе као капитала за људски развој тек је недавно разрађено и у теорији опредмећено. Културни капитал је замишљен као вредност оличена у активности која генерише вредност. Активности могу бити опипљиве (материјалне - на пример, зграда, објекат) или нематеријалне, представљене кроз историју, традицију или идеје. Материјални културни токови капитала могу бити у вези са потрошњом роба и услуга, док су нематеријални културни токови капитала повезани са ставовима који омогућавају појединцима да успоставе мрежу односа.

Расправа о односу културе и друштвеног развоја започела је седамдесетих година XX века и у стручној литератури се покушало разјаснити у којој мери култура утиче на капацитете различитих учесника друштвеног живота да остваре своје интересе у погледу квалитета живота, социјалне доступности, атрактивности и укупне конкурентности градова. Ова дебата је на крају довела до успостављање нове позиције и доживљаја улоге и потенцијала културе у контексту урбане промене. Иако је раније култура схваћена као релативно маргиналан аспект индивидуалне и друштвене активности, углавном ограничен на сферу забаве и слободног времена, она све више постаје испреплетена са главним питањима друштвеног развоја и добија могућност да остварује виши статус у оквиру стратешког управљања које је на дневном реду многих влада.

Културна улагања и активности усмерене на специфичне заједнице постале су потенцијално ефикасан инструмент политике за решавање случајева људског и друштвеног развоја, промовисање неинструменталних начина успостављања друштвених односа колективних идентитета, као и за подршку изградњи и одржавању друштвено одрживих идентитета, и то од виталног значаја. Стратешки значај култура у овом конкретном контексту има не само са својим

\footnotetext{
144 Прелиминарни корак ка дефинисању културне политике у смислу изградње културних стратегија које се развијају управо од стране националних, регионалних или локалних власти, фокусира се и на промоцију културног сектора, али и ка неговању културе у свим аспектима људске активности.
} 
капацитетима обликовања значења колективних процеса и подстицања нових облика друштвености, већ и са стратешком комплементарношћу са развојем нематеријалних ресурса као што су образовање и способности које су фундаменталне за локалне развојне процесе. Зато је и важно бавити се питањем у којој је мери култура у стању да задовољи ове захтевне изазове. Такође, прихватити да развој не обухвата само економске чиниоце, већ и политичке и институционалне факторе.

Разумевање и концептуализација сложености укључених у однос између културе, на једној страни, и развоја или људске еманципације, с друге стране, могли би значајно да се продубе. Пре свега, ако утврдимо шта спаја културу и развој. Можемо потврдити то да се оба термина односе на способност да употребом креативне маште и проналазака кроз процес иновације, произведу нешто радикално ново и оригинално. Без новина и оригиналности - култура и развој не значе готово ништа. Они, заједно, дају подстицај будућим произвођачима културних добара, инвентивним мислиоцима и ствараоцима (креаторима), али исто тако постижу хуманизацију личности.

С друге стране, перцепција угрожавања која се може повезати и са проценом и анализом ризика заснованој на неоспорним чињеницама, има веома важну улогу у утврђивању националног безбедносног оквира сваке земље. При одлучивању (нарочито када се спроводи у сфери безбедности) пожељно је да се примењује принцип рационалности. То није увек једноставно и лако, јер је перцепција угрожавања често условљена културолошким, а понекад и пристрасним предубеђењима. При том, можемо рећи да се културолошка условљеност може свести на две димензије: једну која се ослања на културална знања о другима и предиспозицијама/претпоставкама које нам говоре о томе како ће се ти „други“ понашати, које акције предузети и слично; и другу која се односи на условљеност сопственим културним наслеђем, традицијом, вредностима које нас „уче“ шта то представља опасност и може нас угрозити (што је најчешће историјска чињеница, али није увек и не треба да буде тренутна реалност). 


\section{3 КУЛТУРА И БЕЗБЕДНОСТ}

Да би се схватиле везе између културе и безбедности, а у сврху обликовања концепта безбедносне културе, претпоставља се да се култура манифестује у друштвеним артефактима (предметима, производима), укључујући изграђено наслеђе, начин живота, начин ратовања и сагле́дања безбедносних појава, безбедносну традицију, али и знања и вештине, веровања и вредности. ${ }^{145}$ Пратећи хуманолошку перспективу разумевања културе, можемо рећи и да служи као: (а) извор идентитета унутар групе; (б) средство организације и/или обликовања заједнице (да делује у [не]безбедносним условима кроз вредносне системе и правила која граде и одржавају друштвени капитал који се може манифестовати и кроз развијену способност безбедности - енгл. securitability); и (в) извор (интереса) безбедности. Откривање тих манифестација и улога које култура има када је у питању феномен безбедности нужно налаже да се претходно теоријски обради и прикаже развој теоријске мисли о безбедности.

\section{1 Теоријски основи безбедности}

Свет је место које није безбедно, и зато је оправдано тако често разматрати значење синтагме бити безбедан. Потреба за безбедношћу се јавља из једне опште рањивости коју деле сва људска бића. Животима чак и најбогатијих, најсложенијих и најзаштићенијих друштава често владају страх, насиље и рат. То сазнање је одувек било и полазиште за размишљање о томе шта значи бити

\footnotetext{
${ }^{145}$ На пример, кинеска култура се може видети у Царској палати у Пекингу, у акупунктурном систему медицине и конфучијанским вредностима, бројним борилачким вештинама које су изворно настале управо на кинеском тлу, а све то Кинезима даје осећај идентитета, помаже да се уреди друштво, као и да привуче туристе у Кину или да привуче пацијенте кинеској медицини.
} 
сигуран или безбедан, или како та стања достићи. Небезбедност је, такође, саставни део природе света, а потрага за савршеном безбедношћу илузорна је, чак може и сама постати део проблема, тј. допринети стварању небезбедности и конструисању претњи. Ипак, немогуће је живети а не тражити и налазити решења за претње које нас оптерећују и за промене током којих се заправо производи највише нових претњи.

У сваком случају, безбедност је позитивна вредност која је пожељна, за разлику од небезбедности, која је негативна категорија и стање или чињеница коју треба избегавати. Једна култура, независно од ентитета који представља, у својој основи може производити и пожељне вредности и негативне „вредности“, тј. аномалије. Попут културе, и безбедност је комплексна, има своју теоријску, али и практичну димензију, и производи везе са другим димензијама, као и мноштвом других појмова. Појам безбедности је такође и „суштински споран појам“, нарочито када постаје поље политичког сукобљавања.

\subsection{1 Појам и дефиниције безбедности}

Основни логички услов успешне комуникације, како у теорији (међу теоретичарима) тако и у пракси (међу практичарима), јесте да сваки појам који је предмет комуникације буде прецизно и јасно дефинисан и већ према потребама класификован. Постоји више дефиниција и тумачења безбедности, тешко је рећи која је најпрецизнија и најјаснија, јер су код сваке дате дефиниције или тумачења аутори заузимали различит приступ и критеријум којим су се водили да би објаснили шта појам безбедности заправо значи. ${ }^{146}$

\footnotetext{
${ }^{146}$ У последњих 20-ак година наступила је експлозија концепата и израза везаних за безбедност и очигледна је потреба за повећаним бројем артикулација безбедности. Тако су у употреби изрази: финансијска безбедност, ИТ безбедност, безбедност хране, људска безбедност, друштвена безбедност, здравствена безбедност, енергетска безбедност, правна безбедност и безбедност дома, комерцијална безбедност, као и већ традиционални термин „национална безбедност“.
} 
Потребни су заиста велики ауторитет, као и пратеће компетенције у одређеној области, да би се испунио услов меродавности којим се може процењивати да ли је нешто прецизно и јасно речено. Како је Дидије Биго [Didier Bigo] нагласио у часопису International Political Sociology, врло велики број субјеката може ући у трку за дефиницијом безбедности и свако од њих може предложити различите кораке у том процесу, али улаз у то поље носи и одређену цену. ${ }^{147}$ Каква ће бити конструкција и како ће коначно гласити дефиниција, зависи, као што је већ наглашено, од ауторитета појединца или институције која подноси захтев за објашњењем неке појаве или феномена у односу на одређену публику. Такође, одређен је симболичким и друштвеним капиталом које појединац акумулира. Потребна су и уверења како би се могло рећи да је нешто безбедно или није.

Не може свако констатовати да објекат, ситуација или особа представљају опасност, већ то могу само „одабрани“, тврди Биго. Уза све то, треба узети у обзир и чињеницу да безбедност и небезбедност могу бити и резултати процеса (де)секуритизације. Као што је познато, секуритизација представља увођење готово свих друштвених питања у расправу о безбедности, посебно идентитета, што без аналитичке прецизности може бити само још једно безобално ширење замисли безбедности. Дидије Биго такође наводи да рушење безбедног света доводи до рушења „режима истине“ који су створили професионалци (не)безбедности у својим категоријама, показујући ко ће бити жртвован и из којег разлога. ${ }^{148}$

Због свега реченог, као и код појма културе, за сада ће се наше амбиције кретати у домену приказа оних тумачења и виђења који су у функцији рада, тако да ће се издвојити само поједине из мноштва дефиниција безбедности које су бројни аутори (домаћи и страни) већ навели. ${ }^{149}$

\footnotetext{
${ }^{147}$ Didier Bigo, „International Political Sociology“, In Security Studies, An Introduction, ed. Paul D. Wiliams, Oxon/New York Routledge, 2008, pp 116-129.

${ }^{148}$ Исто.

149 За најшири и најсвеобухватнији преглед становишта која дефинишу или описују безбедност у домаћој литератури погледати код: Љубомир Стајић, Основи система безбедности,
} 
Безбедност сама по себи има прилично непознату историју и сигурно краћу од културне. Појам безбедности из новије историје припада области међународних односа, део је шире политичке научне дисциплине, са сопственим појединим историјским коренима и културно детерминисаном еволуцијом. Пре средине XX века термин „безбедност“ се никада није користио у вези са питањима међународних односа, или уопште у области политике. Крај Другог светског рата представља период када овај термин готово стидљиво почиње да се користи, али ни приближно није имао тако надмоћну улогу коју игра данас.

У древним временима концепт безбедности је првенствено био повезан са духом и духовношћу. Она је била есенција теолошког појма. Безбедност је саглёдана као диспозиција, поглед на свет и духовно стање како у психолошком тако и у моралном погледу. Грчка реч ataraxie (део ума, или у значењу - мир) користила се како би се описало стање безбедности. ${ }^{150}$

На прелазу у Средњи век ataraxia је преведена на латински као securitas. У моралној логици средњовековног хришћанства, securitas је добило негативну конотацију. Наиме, безбедност је имала уочљив субјективан карактер, означавајући недостатак емоционалних и духовних проблема, што је интерпретирано као недостатак бављења тиме. Безбедност је била лично питање које није било повезано са државом, друштвом или било којом другом групом, а у великој мери и даље морално и психолошки заснована. Ако је неко безбедан, како сматра Барџес, он је и без интереса и размишљања, а тиме и без самосвести и вероватно на путу опасности - нарочито у погледу „небеских сила“. Дакле, ако се човек нађе у безбедном стању, у складу са овом

Правни факултет Универзитета у Новом Саду, Нови Сад, 2011; Саша Мијалковић, Национална безбедност, Криминалистичко-полицијска академија, Београд, 2009; Младен Бајагић, Основи безбедности, Криминалистичко-полицијска академија, Београд, 2007; Драган Симић: Наука о безбедности - савремени приступи безбедности, Факултет политичких наука, Службени лист, Београд, 2002.

${ }^{150}$ J. Peter Burgess, „Security as Ethics“, Policy Brief, No 6/2008, Oslo: PRIO. 
интерпретацијом, онда је и без проблема, без туге и без размишљања. Другим речима, без бриге, без самосвести, будности и поштовања за себе и друге.

Самим померањем значења са ataraxia на securitas и конотација је померена ближе начину на који разумемо данас безбедност - као стабилност, снага. Римска верзија безбедности је имала више објективног карактера. Бригу и разматрање безбедности могли су да деле многи појединци, чиме су створене основе за колективно разумевање, колективни приступ и колективну акцију.

Током Средњег века термини certitudo и securitas пошли су различитим путевима. Идеја certitudo (у енглеском језику данас реч - certain - у значењу извесност, сигурност) омогућила је појмовно раздвајање од гране безбедности више оријентисане ка знању - дакле, у односу на мишљење - од појма securitas. Certitudo значи безбедност у знању, мисли, убеђењу, извесност, а овај појам је задржао идеју безбедности као индивидуалну. Та повезаност је и омогућила да се развије модерна концепција безбедности. ${ }^{151}$

Безбедност представљена појмом securitas била је више објективна мисао, мисао о опасности у спољашњости - не у унутрашњости. Ослобођена је субјективног аспекта претње, опасности и ризика, од моралне димензије безбедности, повезаности са Богом, космосом, другим индивидуама. Дакле, била је потпуно објективизована.

Феудални период води дискурс безбедности као претворене у економски систем добара и услуга. Безбедност је могла бити купљена и продата. Функција феудалног кнеза била је у неку руку да понуди безбедност онима који би за њу могли да плате. Тако је и реч „безбедан“ почела да проналази своју модерну употребу у XIV веку, када је обезбеђење путева, нарочито за трговце и ходочаснике, постало велики проблем. У том смислу су потписивани уговори између царева, кнежева и војвода (војводе од Аустрије и Баварске, 1375.

${ }^{151}$ Исто. 
године) којима је постигнут договор да се заштите и обезбеде сви важни путеви. ${ }^{152}$

С друге стране, такође постоји претпоставка да реч безбедност има корене у грчком изразу asphaleia $[\alpha \sigma \varphi \alpha \lambda \varepsilon 1 \alpha]$ у значењу - избегавање грешке, узрока пропасти, пораза, што у пренесеном значењу подразумева владање ситуацијом, спречавање пропасти, извесност победе, присебност, срећу и слично. ${ }^{153}$ Којем ћемо се значењу приклонити, зависи како од етимолошког тумачења и критичког приступа значењу појма безбедности, тако и од начина на који су се одређени језици развијали и за које се потребе конституисао тај и слични појмови у једном језичком комплексу.

Када је 1947. године Труман потписао Закон о националној безбедности САД одједном су се неке ствари промениле. Појам безбедности је замењен вишим нивоом, представљеним у форми националне безбедности. Као резултат снажног утицаја идеологије Хладног рата, појам је незадрживо и некритички ушао у оптицај широм света током 40 година. Термин „национална безбедност“ био је пре Другог светског рата потпуно непознат. Опажање стварне и имагинарне претње против националне државе за време Хладног рата допринело је ренесанси појма безбедности.

Безбедност као стање без претњи, општа заштита од потенцијалне претње, стајала је као опозиција појму класичне одбране, која је представљала стратегију са јасним објектом потенцијалног напада. Појам је даље кристализован и институционализован кроз институционализацију безбедности и стратешких истраживања, а када је нуклеарна претња увршћена у безбедносну једначину, ојачале су и безбедносне студије у предмет и оруђе стратешке анализе.

Без обзира на то да ли на безбедност гледамо из шире или уже перспективе, она представља одређено уређење опасности, претње, уточиште, благостање и

152 Amir Pasic, „Culture, Identity and Security: An Overview“, видети: http//www.humansecurity.com/documents/RBF_cultureidsecurity.pdf

${ }^{153}$ M. Dillon, Politics of Security - Towards a political philosophy of continental thought, London, Routledge, New York, 2003. 
слично. Између уточишта и угроженог места настају структуриране везе, које уоквирују релацију између благостања и угрожавања, опасности или претње.

Такође, независно од тумачења са којима се сусрећемо у литератури о безбедности, она није просто стање ствари или ситуација. Кроз неку врсту дијалектичке логике, безбедност је одсуство небезбедности, а реално је могућа само са мишљу о небезбедности, кроз припрему не за оно што још није случај, већ за оно што би могло бити случај. Безбедност мора да уради далеко мање са оним што је познато него са оним што је непознато. Тако се и безбедност схвата и проживљава као „начин бављења овим непознатим, средство преузимања акције у лице непознате опасности, у лице непознатог као сама опасност, чак и опасности као непознате. У овом смислу се безбедност може тумачити као нека врста епистемологије. Врста система за бављење знањем или незнањем, које је непотпуно или неадекватно знање о опасности.“154

Појам безбедности је ушао у поље разматрања бројних научних дисциплина, неких пре, а неких пошто се указала потреба да се развију посебне студије безбедности, које су у фокус својих истраживања ставиле управо овај феномен. Тако ћемо прво размотрити социолошки, правни, политиколошки, а затим и културолошки поглед на безбедност.

\subsubsection{1 Социолошки приступ}

Социолошки приступ безбедности посматра безбедност као стање система друштвених односа између различитих субјеката на различитим нивоима функционисања (међудржавном, међуличном итд), и у различитим областима деловања - политичкој, економској, социјалној или некој другој сфери.

\footnotetext{
154 Безбедност је виртуелно знање, основа за то како деловати ако је адекватно знање било активно. У том смислу то представља наставак класичне опозиције из теорије праведног рата између превенције (одбрамбено деловање против доказане агресије) и преемптности право прече куповине (одбрамбено деловање против вероватне агресије). Видети: J. Peter Burgess, What is security culture?, The New ethos of risk, International Peace Research Institute, PRIO, Oslo или The Routledge Handbook of New Security Studies, edited by J. Peter Burgess, Routledge, 2010.
} 
То стање друштвених односа најчешће се огледа у понашању појединца, друштвене групе или државе, при чему ти исти субјекти могу самостално и слободно, без спољних мешања и притисака изабрати и остваривати стратегију која ће определити њихово понашање и на међународној сцени, али и духовни, социјално-економски, политички и сваки други развој.

Социолошки приступ безбедности подразумева и успостављање безбедности као основног друштвеног процеса (променљива, али интегрална компонента свих односа), без којег би друштвени живот био и бесмислен и релативно опасан. Дефинисати безбедност са социолошког аспекта веома је тешко, јер су управо социолози и највише игнорисали овај концепт, пошто су се углавном фокусирали на друге феномене, као што су моћ, ауторитет, ред и контрола. Такође, концентрисали су се и на изборне процесе, интересне групе, политичке организације и социјализацију. ${ }^{155}$

Социолог Кевин Клементс [Kevin Clements] ${ }^{156}$ дефинисао је безбедност „као основни друштвени процес (са неким инстинктивним, спонтаним својствима) чији је циљ постизање релативно сигурне друштвене, политичке и економске заједнице (или простора). Такве заједнице омогућавају људима да живе, крећу се и буду искрене према својим културама, језицима и идентитету без страха од директне или индиректне претње насиљем. „Интегративни односи“157 су и

${ }^{155}$ Kevin Clements, Toward a Sociology of Security, Working Paper 90-4, July, 1990, Department of Sociology University of Canterbury Christchurch 1, New Zealand.

${ }^{156}$ Професор Клементс је, између осталог, и директор Националног центра за мир и Студија конфликта (NCPACS) на Новом Зеланду.

157 Повезивање безбедности експлицитне заједнице у изградњи и проширењу безбедног простора обезбеђује појединце, друштвене покрете и политичке лидере са важним критеријумима за одређивање је ли вероватно или не да ће понашање повећати или смањити нето безбедност. Ако активности појединаца, влада, великих корпорација или међународних организација немају за последицу експанзију интегративних односа, онда ће вероватно генерисати краткорочне или дугорочне несигурности и склоности ка претњама. Ако као крајњи резултат у ширем смислу уочавамо заједнице у којима су договором подељени скупови обавеза и одговорности (на локалном, националном и међународном нивоу), вероватно ће и безбедност бити унапређена. 
узрок и последица таквог безбедносног простора или заједнице и они ће доминирати и у односима деструкције и претње. Према Клементсу, безбедна заједница се одликује институцијама које олакшавају сарадњу, ненасилно решавање конфликта и мирољубиве друштвене трансформације.

Сви структурни елементи једног друштва имају одређено виђење безбедности, она је део њиховог облика егзистенције, односно начина живота, а уткана је и у све њихове активности којима себи обезбеђују просперитет и развој. Из њихових активности произлазе и одређене законитости, на основу којих се безбедност сврстава међу примарне области друштвених односа. Тако се, на пример, каже да су жене много свесније крхкости безбедности од мушкараца. Због тога њихове перцепције сопственог интереса доводе до интеракције са другим женама и мушкарцима чији је циљ јачање поверења, поузданости и заједништва.

То доводи и до нових концепција безбедности, које се разликују од виђења мушкараца, а нова размишљања о националној или глобалној безбедности морала би да уграде и ове феминистичке критике, јер оне подвлаче неопходност за померањем равнотеже у дискусијама безбедности више према комуналним него индивидуалистичким решењима. Наиме, мушкарци имају тенденцију да буду изолованији, отуђенији и сами у односу на жене, које су обично за контакт, отвореност и заједништво. Ова два приступа „реалности“, било који да је доминантан, резултују различитим дефиницијама безбедности и опасности. $^{158}$

Такође, оно што изазива дилему и отвара неке нове дискусије у социолошким разматрањима јесу комплексност и непредвидивост живота, у којем највећим делом сигурност и опасност коегзистирају у истим објектима и праксама. Под одговарајућим (погрешним) условима, све што је потребно за живот може такође да осакати или убије: вода може удавити, храна може отровати, ваздух може угушити. Беба не може да се роди а да у исто време не представља

${ }^{158}$ Видети шире: Terrie Northrup, „Personal Security, Political Security: Relationship Between Conceptions of Gender, War and Peace“, Paper submitted for publication, in: L. Kreisberg (ed.), Research in Social Movements, Conflict and Change, Syracuse University, Vol. 12, 2008. 
опасност за мајку; свака јединка док одрасте до зрелог доба суочава се са безбројним опасностима. Шта овде треба уочити: не како да се избегне ризик или опасност, јер је то немогуће, већ како да се користи ризик да се добије мање или више жељених ствари. Модерним речником исказано, не како да се избегне ризик, већ како да се управља ризицима.

Потрага за безбедношћу представља један балансирајући чин, све је повезано и не постоји избор чији резултат неће донети некакву непријатност или нелагоду. Безбедност, дакле, има и субјективну димензију и свој прави смисао добија тек када покренемо додатна питања, која нам омогућавају да откријемо како његов смисао виде поједини актери, групе, организације, друштва, народи и други субјекти. Безбедност тако постаје заснован појам и преузима одређени смисао. Безбедност за кога, за шта и у којим околностима или условима?

Безбедност може представљати услов бројних облика социјалне покретљивости, a, у зависности од начина на који се врши друштвено структурирање, може бити ускраћена појединим структурним елементима, услед конфликта или свеопште друштвене нестабилности. Породице се популарно схватају као архетипски безбедна места. Иако је ово вероватно тачно за већину породица, у готово свим друштвима постоје значајне мањине за које су ове интимне заједнице веома небезбедне и заиста су мета насиља и агресије. Прихватајући ову чињеницу не тврдимо да треба укинути институцију породице, већ признати да се интимност понекад злоупотребљава и да постоји крхкост и рањивост целокупног друштвеног живота.

Безбедност није циљ који је коначно достигнут, тако да свака друштвена размена представља прилику за наглашавање елемената који повећавају безбедност и поверење или, алтернативно, непредвидиве и хаотичне могућности. Друштва су опстала, опстају и опстаће у будућности, јер већина актера радије бира безбедно него дестабилизујуће понашање.

Социолошки поглед на безбедност покушава да укаже и на могућност да је традиционални реалистички поглед на безбедност испоручио више небезбедности него безбедности и да су самим тим грађани, за разлику од државе, постали отуђени од концепта и процеса који су од суштинског значаја 
за њихов опстанак. Остваривање друштвеног поретка и релативно безбедног окружења може се боље објаснити, али и достићи без принуде и без насиља него принудом и применом насиља. У већини земаља света ненасилне методе имају превагу над насилним. Они су норма, а насилни принудни процеси се изузимају.

Модерни и постмодерни теоретичари нису ограничени песимистичким и мрачним гледиштем на људску природу, као што су то уочили Хобс и реалистичка школа, коју је покренуо. Насупрот томе, реконцептуализација безбедности на основу које се оправдавају средства каквима већина појединаца достиже осећај сигурности и стварне безбедности може да пружи много креативних начина решавања бруталности, нехуманости, претње, страха и узнемирености од оних које тренутно нуде менаџери „националне безбедности“. 159

Пошто латински корен безбедности securus значи „без бриге“, можемо рећи и да безбедност потиче из друштвених процеса који смањују ризик, побољшавају нормалност, предвидљивост и међусобну сигурност. Кључно питање у овим разматрањима може бити и: колико неизвесности и несигурности може представљати оптимално стање за креативни подухват и када се небезбедност може доказати као дисфункционална за појединце и друштво? Људи који се баве популарним екстремним спортовима, као што су: банџи-џампинг, параглајдинг, алпинизам и слични, намерно се излажу ризику како би

159 Они који настоје да гарантују безбедност претњама и казнама (поред менаџера националне безбедности, ту су и полиција, наоружани криминалци итд.) налазе се у мањини (иако медији тврде другачије). Већина људи у већини земаља света вежба уздржаност и реципроцитет у међуљудским односима, те на тај начин стварају неопходне услове за релативно стабилне, безбедне друштвене интеракције. Ако би свако радио на основу претње/противпретње и размишљања о најгорем, друштвени живот би био немогућ. То, опет, не значи да не постоје претње или да је небезбедност једноставно последица погрешне социјализације, те уједно сугерише и да нормалан друштвени живот, мирољубиво понашање, друштвено-политичка и економско-безбедносна ситуација почивају на нечему што није избегавање опасности и ризика. Безбедност почива пре свега на спремности да се делује у поверењу и очекивању да ће већина појединаца временом почети да узајамно верују једни другима. 
доживели то стање, насупрот безбедности и стабилности које имају у свакодневном животу. При том, други, који живе у веома опасним условима на маргинама егзистенције, желе минималне нивое безбедности како би осигурали свој опстанак.

Уграђивање концепта безбедности у основне друштвене процесе може помоћи у оспоравању доминантних политичких ставова о безбедности и омогућити грађанима да утврде да ли институције које су основане за генерисање безбедности заиста и испоручују оно што обећавају. Постоје и фундаменталне лекције које треба научити из политичких револуција које су се одиграле крајем осамдесетих и током деведесетих година двадесетог века. Прва је да границе могућности више зависе од квалитета наше маште него доживљаја непроменљивости друштвених и политичких реалности, а друга је да моћ и легитимитет државних система зависе од сагласности влада.

Грађани који сматрају да држава генерише више несигурности него безбедности имају легитимно право да сруше те органе. То су, наравно, у стању да учине због интуитивног или наученог осећаја сигурности или безбедности, који мало или готово ништа дугују акцијама државе.

\subsubsection{2 Правни приступ}

Право се, између осталог, може означити и као нормативно уређени поредак којим се дефинише однос државних институција и према потребама безбедности. Сагле́дање и тумачење безбедности може се одвијати и према томе како је успостављен и како функционише правни систем једне државе. Право, као што знамо, има двоструку функцију: као прво, омогућава субјектима - и правним и физичким лицима - да остварују одређени интерес у друштву, а, као друго, те субјекте ограничава у њиховом понашању у смислу да их спречи или казни за непоштовање одређеног правила понашања.

Циљ права је да одреди, успостави и одржи ред као пожељно стање већине. Уколико нема реда, и опстанак друштва се доводи у питање. Циљ права је такође да одржи мир, а потреба за одржавањем друштвеног мира чини и непосредан повод за настанак права. Са редом и миром повезана је сигурност, 
која се односи на благовремену и потпуну примену права, или поуздано уверење да ће право бити примењено, или на решавање спорова у друштвеним сукобима. Пошто омогућава одвијање заједничког живота са што мање неусклађености, препрека, сукоба и борби, који слабе или разарају друштво и непотребно троше енергију људи, „право у људске односе уноси неопходну предвидљивост и извесност, ослобађа људску стваралачку енергију, повећава друштвену стабилност и доводи до друштвеног напретка““. 160

Како се фаворизује правни поредак са развијеном демократијом и системом људских права и слобода, тако је и могућа већа безбедносна стабилност уз на одговарајући начин обликоване институције које је штите. При том, прихватамо двојако схватање институције - и као норме и као организације. Оксфордски речник енглеског језика [Oxford English Dictionary] дефинише институцију као „установљени закон, обичај, навика, пракса, организација или неки други елемент у политичком или друштвеном животу“. Такође се описује и као ,јавна установа, организација или удружење, које је установљено како би се унапредио неки циљ, посебно онај који је од јавног или општег значаја...“

Правна држава представља „општи постулат друштва“ и њен задатак је унапређивање свих човекових могућности. У правној држави сви захвати власти морају да буду „изузетни, мерљиви, предвидљиви и подложни објективној контроли“, док њене одлуке морају да буду „етички добре и на моралу засноване“. Садржај правне државе је у међувремену изједначаван са задацима тзв. „државе благостања“ [Welfare State], а затим и са задацима „културне државе““ [Kulturstaat], док се последњих деценија везује за најшире постојање и поштовање људских слобода и права.

Када постоји послушност у погледу скупа максима у неком друштву према којем се оријентишу поступци чланова друштва, то по Веберу значи да постоји поредак. Вебер сматра да поредак може бити гарантован на два начина. Прво, на основу субјективних разлога: афективног веровања, вредносно-рационалног веровања или веровања у легитимност, и друго - очекивањем одређених

\footnotetext{
${ }^{160}$ Радомир Лукић, Увод у право, Научна књига, Београд, 1978.

${ }^{161}$ Oxford English Dictionary, видети: http://oxforddictionaries.com/definition/institution
} 
спољашњих ефеката, односно санкција, које могу да имају облик прихватања или неприхватања нечега у оквиру групе када је реч о конвенцији, или облик физичке или психолошке принуде када је реч о закону. ${ }^{162}$

Правни поредак преко система правних норми (правни систем) дефинише виталне националне вредности, субјекте безбедности (њихову организацију, надлежности, послове и задатке), начине достизања, заштите и унапређења свих друштвених вредности, начине спровођења државних функција и функционисања великих друштвених система (енергетског, образовног, привредног, здравственог итд), као и одређивање основне националне платформе за учешће у међународним односима и допринос националној, међународној и глобалној безбедности.

Позивајући се на право, односно сагле́дајући са правног аспекта, Слободан Милетић је дефинисао безбедност као „правно уређиваним и обезбеђиваним друштвеним односима успостављено, одржавано и унапређивано стање у држави, које омогућава ефективну заштићеност државе и грађана који у юој живе од свих (спољних и унутрашњих) противправних аката (активности) којима се угрожава[jу] уставни поредак, суверенитет, независност $u$ територијална целокупност државе, рад државних органа, обављање привредних и друштвених делатности и остваривање слободе, права $и$ дужности човека и грађанина.“163

Пошто се све више истиче вишедимензионалност функције коју безбедност има у друштву, то се и примећују одређени недостаци оваквог приступа. Позитивноправно дефинисање неке појаве обично се задржава на спољним обележјима, нормативном устројству и организационој структури, што нам не пружа праву слику о суштини појаве и о њеном односу са другим појавама.

162 J.-A. Lane and S. Ersson, The New Institutional Politics: Performance and Outcomes, Routledge, London and New York, 2000, стр. 23-37; према: Insitucije i institucionalizam, priredili: Petar Bojanić i Ivan Mladenović, Službeni glasnik, Beograd, 2010.

${ }^{163}$ Према: Љубомир Стајић, Основи система безбедности, Правни факултет, Универзитет у Новом Саду, 2010. 


\subsubsection{3 Политиколошки приступ}

Према неким савременим теоретичарима који се баве питањем државе и међународним односима, савремена политика представља један „безбедносни пројект“ који претходи, али и оправдава ставове политичких теоретичара и саму праксу појединих држава. ${ }^{164}$ Модерна политика у свом речнику веома често барата појмом безбедности, који се представља као први и темељни услов државе, па се често каже да нема безбедности без државе, а ни државе без безбедности.

Или, како је говорио Аристотел: „Јасно је да све заједнице теже неком добру, а она која је од свих најмоћнија и која све остале у себи обухвата, тежи добру највећем од свих. Она се зове држава, односно политичка заједница.“165 Она је управо та заједница која настоји да уздигне људе на истинску људску раван, да им омогући живот у врлини, живот испуњен оним што је лепо и добро, дакле и живот који човек живи сигурно и безбедно.

Политиколози претпостављају да је безбедност питање опстанка националне државе - дакле, повезана је са очувањем интегритета државе и заштите националних вредности од стварних или измишљених противника. Немачки теоретичар права и политике, иначе дуго оспораван, Карл Шмит [Karl Schmitt] сагле́дао је политику у категоријама пријатељ-непријатељ, где је рат представљен као крајња реализација непријатељства. У њему се, као у најекстремнијем политичком средству, открива могућност разликовања пријатеља од непријатеља.

Рат није нешто свакодневно и људи нису у сталном рату једни против других. Од одлучујуће важности јесте постојање реалне могућности избијања ратних сукоба, која и одређује људско мишљење и понашање. Политичко̄ није само у борби, већ у „понашању које је одређено том реалном могућношћу, у јасном

\footnotetext{
${ }^{164}$ Dillon, M.: Politics of security. Towards a political philosophy of continental thought, Routledge, London, 2003.

165 Аристотел, Политика, БИГЗ, Београд, 2003; према: Михајло Ђурић, Историја политичке филозофије, Албатрос плус, Београд, 2010, стр. 134.
} 
сазнању сопствене, тиме одређене ситуације и у задатку да се пријатељ и непријатељ тачно разликују“. ${ }^{166}$

Према Шмиту, смисао разликовања пријатеља од непријатеља јесте да се утврди крајња тачка где долази до груписања или раздвајања. Људи могу имати различите мотиве: религијске, националне, привредне или друге врсте и они могу у различитим временима изазивати различита повезивања, а често и супротности. Када супротност постане довољно снажна да људе ефективно групише на пријатеље и непријатеље, она нужно постаје и политичка.

Држави, као меродавном политичком ентитету, припада право да одређује непријатеља, тј. она поседује jus belli. Ово право подразумева могућност да се од чланова заједнице захтева спремност на жртвовање и убијање, као и спремност да се убијају људи са друге, непријатељске стране. Такође је познато да свака држава има обавезу да у оквиру својих граница обезбеди мир и сигурност, тј. да створи нормалну ситуацију како би могле важити правне норме. У критичним ситуацијама држава одређује и „унутрашње непријатеље“, што је, опет, више одлика тоталитарних режима, а у свеопштој осуди таквих режима и појам непријатеља је изазвао опречна мишљења и тумачења. Савремена друштвена и политичка динамика показале су да постојање „другог“, односно непријатеља, није својство само ауторитарних поредака и тоталитарних режима, већ и да либерална демократија није имуна на такву праксу. ${ }^{167}$

У пракси је безбедност постала нераскидиво повезана са активностима дипломата, стручњака за безбедност, војних лица, политичара и оних академаца који проучавају такве људе. Безбедност је тако постала оно што националне безбедносне елите кажу да јесте. Наравно, мало је напора да се

${ }^{166}$ К. Шмит, „Појам политичкога“, у: Норма и одлука: Карл Шмит и његови критичари, ур. Слободан Самарџић, „Филип Вишњић“, Београд, 2001, стр. 1-67.

${ }^{167}$ Глобална борба против тероризма, као и потрага и прогон терориста које су западне земље, предвођене САД, отпочеле након 11. септембра 2001. године, утицали су, између осталог, и да се другачије читају дела Карла Шмита и да се изнова проблематизује питање пријатеља и непријатеља. 
утврди да ли се ти ставови подударају са оним другим „гранама“ државе или ширим погледима грађана, на шта су посебно указивали напред поменути социолошки приступи, или приступи концепта људске безбедности који истичу важност обраћања пажње на осећања и субјективност подједнако као и на објективне животне околности. Разумевање безбедности подразумева велику пажњу коју треба посветити и садржајима личних живота појединаца као и људској дубини.

Безбедност се може представити и као један од оних организационих концепата које политиколози крајем XX века (посебно међународних односа и стратешки аналитичари) користе бирократски без икакве расправе (Arnold Wolfers и Barry Buzan два су значајна изузетка). Заправо, већина емпиријских студија из међународних односа и стратешких студија једноставно описују процесе који одржавају домаћи status quo и устаљено, сада већ застарело, централно ривалство између две нуклеарне суперсиле на глобалном нивоу. Читав период Хладног рата, укључујући ово централно ривалство између Сједињених Америчких Држава и Совјетског Савеза, резултовао је склоношћу ка искључиво политичким и војним дефиницијама безбедности, а против шире, инклузивне друштвено-културне дефиниције.

У Малој политичкој енцииклопедији „безбедност“ у најширем политичкоправном смислу обухвата мере и активности чувања и заштите од угрожавања независности и интегритета једне земље (државе, нације) и унутрашњег уставног и правног поретка. У првом случају се говори о спољној, а у другом о унутрашњој безбедности. Према објекту заштите разликују се: национална безбедност, јавна безбедност, колективна безбедност и лична и имовинска безбедност. ${ }^{168}$

Колико се то види из ове дефиниције или ранијег излагања, политиколошки поглед на безбедност третира је као основну бригу државе, која треба да уреди и контролише друштвене односе унутар својих граница, а када се преклапа са

\footnotetext{
168 Према: Љубомир Стајић, Основи система безбедности, Правни факултет, Универзитет у Новом Саду, 2010.
} 
садржајем националног интереса, представља и важно средство политичке акције у односима са другим државама.

\subsubsection{4 Културолошки приступ}

Како је Питер Берк [Peter Burke] нагласио у свом делу What is cultural history (код нас преведено као Основи културне историје), експанзија царства културе подразумева и све снажнију склоност ка нуђењу културолошких објашњења за економске феномене и промене у свету политике, какве су револуције, настајање држава и слично. ${ }^{169}$

Специфичност културолошког приступа одређеним друштвеним појавама, па тако и безбедности, изнедрила је и различита промишљања културолога када је у питању овај феномен. У сваком случају, можемо рећи да безбедност проистиче из истог процеса као и култура - дакле, безбедност се може разматрати као спона између природног стања, у којем је човек апсолутно слободан, али изложен бројним опасностима, и друштвеног стања у које је ступио када је одлучио да се усагласи и удружи са другим људима под окриље централне власти, како би живели безбедно и у миру (видети схему 2). Култура је та која људска природна својства уводи у мрежу друштвених институција, развијајући и поштујући вредности које темеље одређени идентитет који у крајњем процесу дефинисања добија препознатљиву структуру постојања дакле, оно што зовемо ентитет.

Као полазни материјал за истраживање безбедности теоретичари културе узимају факте културе и факте њених појава испољене кроз различите форме и

169 Исти аутор наводи сјајан пример културолошког објашњења политичког догађаја које је описао F. S. L. Lyons у својој књизи Култура и анархија у Ирској (Culture and Anarchy in Ireland, 1890-1939, објављена 1979). Наиме, Лајонс пише да је његова земља подељена на четири културе - културе Енглеза, Ираца, Англо-Ираца и алстерских (северноирских) протестаната, четири заједнице „које не могу да живе ни заједно ни одвојено“. Сматрао је да су политички проблеми релативно површне манифестације дубљих културних сукоба или „колизија“, те апеловао да се више пажње посвети културној историји, која је у Ирској у том тренутку била још „у повоју“. Видети: Питер Берк, Основи културне историје, Клио, Београд, 2010. 
резултате одређених активности. То подразумева мисаоно репродуковање културе као интегралног јединства форми и праваца активности у безбедности, затим изучавање унутрашњих законитости њиховог развоја, на пример: развој насеобина ради заштите од непријатеља, начина комуницирања у условима присутне опасности, техничких, мисаоних и уметничких форми с изражавањем промишљања о безбедности - дозвољава да се начине аргументоване прогнозе о суштини и могућностима развоја друштвеног субјекта (ентитет), било да је то појединац, друштвена група, друштво у целини или држава. Суштину и развој ових субјеката посебно је значајно пратити у делатностима које заузимају поље безбедности.

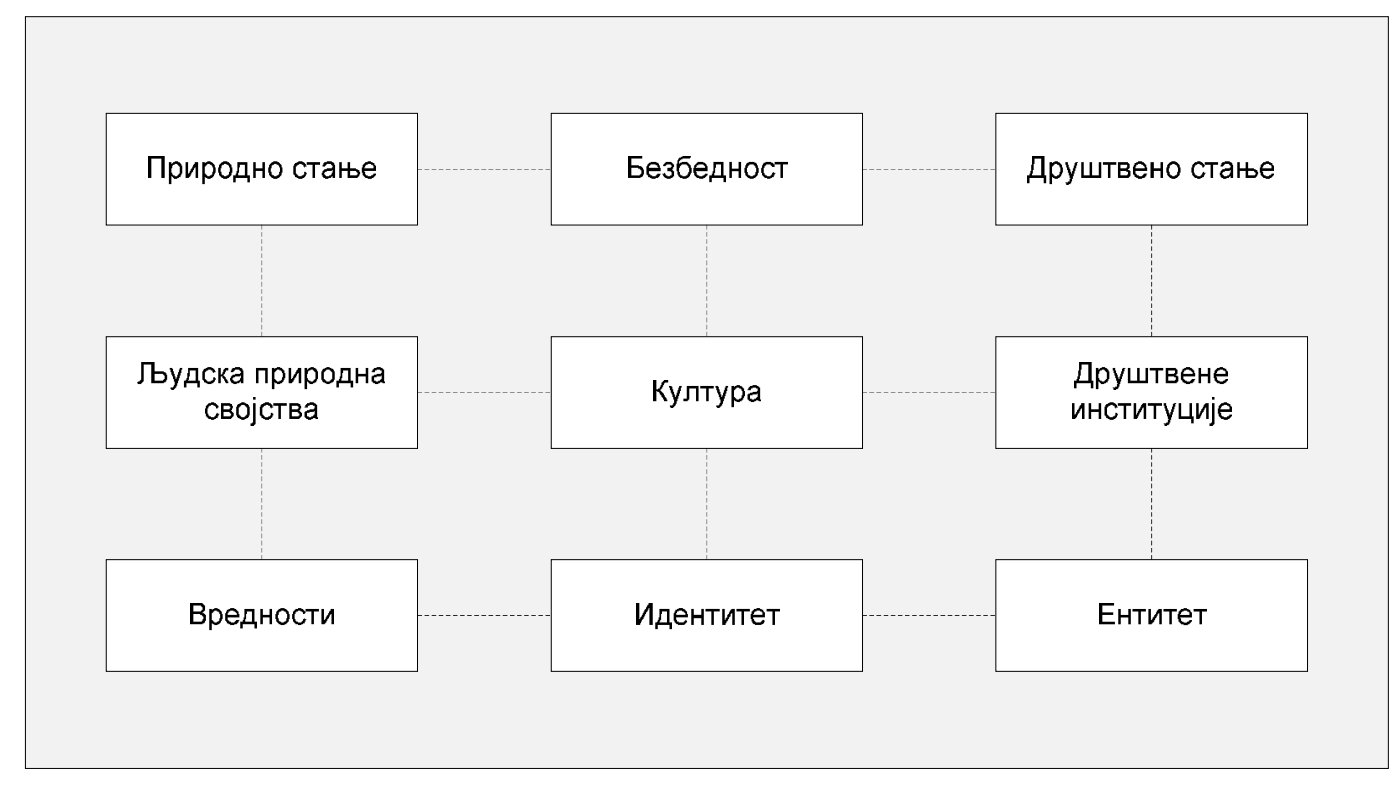

Схема 2. Културолошки аспект безбедности

У оквиру реалистичко-либералне дебате у другој половини XX века, која је на махове добијала реалистичко-конструктивистичке обрисе, јавила су се и питања на који начин функционише свет, да ли су то идеацијски фактори или материјална снага - и ко има значајнију улогу. У својим главним токовима дебата је фокусирана на „понашање“ држава и степена где идеје, са једне стране, и интереси, са друге стране, имају најзначајнији „утицај“ на то понашање. 
Сви културолози у студијама безбедности ипак заступају јединствено становиште по којем истински верују у реализам као доминантни програм истраживања у међународним односима, али факторе попут материјалног баланса снага виде као прецењене. Наиме, они сматрају да културолошке теорије које се управљају идејним или идеацијским факторима дају неупоредиво боље објашњење како свет функционише или, да додамо, представљају фактор који значајно помаже да добијемо јаснију и свеобухватнију слику о томе.

О културолошком приступу безбедности више ћемо сазнати у одељку који следи, а у којем се разматра како је све култура артикулисана у концептима безбедности од Другог светског рата до данас.

\section{2 Артикулација културе у концептима безбедности}

У уводном делу већ смо нагласили да на пољу међународне безбедности, културолошке теорије заузимају веома значајно место, нарочито након Другог светског рата. Све теорије су усмерене ка понашању државе, а обухватају обиман програм са широким спектром тема истраживања (као што су војна доктрина, набавка и куповина наоружања, велике стратегије, доношење одлука у спољној политици) и користе читав низ објашњавајућих варијабли.

Од почетка Другог светског рата до данас теоретичари су уочили три таласа у којима се култура појавила као важан фактор, о којем се све више полемише у студијама безбедности. ${ }^{170}$ Први талас се везује за Други светски рат и дилему како се носити са Силама осовине, са којом су се суочили културални теоретичари у САД. Наиме, при Министарству ратног информисања постојало је Одељење за анализу иностраног морала [Foreign Morale Analysis Division of the Office of War Information], које је упошљавало велики број тада водећих културних антрополога, међу којима су били и: Бејтсон [Geoffrey Bateson],

170 Michael C. Desch, Culture Clash, „Assessing the Importance of Ideas in Security Studies“, International Security, Vol. 23, No 1 (Summer 1998), pp. 141-170. 
Бенедикт [Ruth Benedict], Горер [Geoffrey Gorer], Клакхон [Clyde Kluckhon], Лејтон [Alexander Leighton] и Мид [Margareth Mead]. Њихова основна активност базирала се на изради студије „националног карактера“ Сила̂ осовине, нарочито Јапана и Немачке. Наиме, оспораван је њихов утицај на стварни ток рата, али је било и јасно да је „национални карактер“ одиграо огромну улогу у јавном дискурсу о забринутости за природу непријатеља током Другог светског рата. ${ }^{171}$

${ }^{171}$ Џон Довер, професор јапанских студија, покушао је у свом раду да образложи моћ и утицај расизма на Пацифику, важном попришту из Другог светског рата. Довер тврди да је рат на Пацифику за обе стране - и Америку и Јапан - био осетно више дивљи и насилан од европских попришта, јер, паралелно, расизам у америчкој и у јапанској култури није оставио простор за милост. Цртежи на бројним неконвенционалним изворима пропаганде, као што су политичке карикатуре, документарни филмови, разне анимације, текстови популарних песама и слични материјали, према Доверу убедљиво доказују да су обе зараћене културе прожете етноцентричним осећаем супериорности, које не оправдава „зачарано“ понашање током рата, али доводи до прекомерног самопоуздања и ефективних војних операција широм Пацифика. У време Перл Харбура у САД већ је дубоко била укорењена расна мржња и страх од Азијата. „Опасност од жутих“ потиче још из страха од кинеског контакта и конкуренције на западној обали, где се водила рестриктивна политика и спроводили строги имиграциони закони. Будућност Кинеза и других Азијата угрожавала је англоамеричка политичка култура деценијама пре Другог светског рата. Трансфер мржње и страха од Кинеза релативно се лако пренео на Јапанце, посебно након „научних“ порука расизма које су се појавиле у јапанској култури 1930. године. Расне теорије из деветнаестог века изложиле су широко прихваћено мишљење да су расне касте хијерархијски уређене, са белцима, посебно Англосаксонцима, на врху. Културни антрополози раног двадесетог века активно су радили на томе да поткопају овај расистички поглед на свет третирањем свих цивилизација као равноправних. Струје мржње и неповерења према Јапанцима и свему што је јапанско предводиле су Американце са много злог менталитета да нема заробљеника током сукоба, као у Немачкој. Прикупљање ушију, носева, лобања и костију постало је преовладавајуће на Пацифику, а не у Европи. Убијање ратних заробљеника и употреба атомске бомбе из ове дехуманизације непријатеља десили су се такође на Пацифику, а не на европској позорници. Јапанци су реципрочно испољили веома развијену расну мржњу према Западу. Традиционална културна уверења у центар универзума стављају Јапанце са божанском наследношћу, предодређене за глобалну супремацију. Јапански расизам је довео до разорних експлоатација азијских суседа. Пошто би успео да контролише Азију, Јапан је имао визију да крене да осваја свет, а први наговештаји тога су ратови које је почетком 
Убрзо након завршетка рата први талас културних теорија изгубио је на значају, између осталог, и као последица нуклеарне револуције. Нуклеарно оружје је до те мере деструктивно да су у поређењу са њим културне разлике постале, благо речено, ирелевантне. На сцену су ступиле опште теорије стратешког понашања, као што је, на пример, теорија одвраћања [deterrence]. Неспремност Совјетског Савеза да се заустави када је достигао нуклеарни паритет, као и пораз САД у рату у Вијетнаму, умањили су значај општих теорија застрашивања и принуде.

Континуирана нуклеарна надградња Совјетског Савеза изнад „прихватљиве“ границе водила је у гарантовану деструкцију. То је утицало на многе научнике да испитају рационално дејство претпоставки већине општих теорија и утицаје нуклеарног наоружања на вештину вођења државе. Неуспех САД у напорима да спречи колапс не-комунистичког режима у Јужном Вијетнаму такође је утицао на смањење значаја општих теорија политичког и економског развоја и довођење у питање рационалног дејства теорије ограниченог рата. ${ }^{172}$

двадесетог века водио против Кине и Русије. Целисходни савез са Немачком и Италијом у Другом светском рату дозволио је Јапану да се представи као ослободилац од колонијалних сила Велике Британије и Америке на Пацифику. Међутим, јапанска инвазија на западне колоније Бурму и Индокину мало је променила ствари за експлоатисане домороце. Довер је открио трагове дехуманизације западњака у оквиру јапанске поп-културе. Цртани филмови, музика, филмови са Запада потврђују да су Јапанци посматрали западњаке, поготово Американце, као меке, феминизоване, себичне, опседнуте луксузом, лицемерне итд. Амерички симболи и лидери, попут ујка Сема и Рузвелта, постали су симболи непокретности, слабости, ништавности и старости. Активни амерички империјалисти и војници били су демонизовани у визуелне медије са роговима, копитама, канџама. Довер тврди да је много јапанских камиказа или самомученика отишло у смрт услед истинског страха да буду ухваћени од стране демонске америчке силе. Коначно, Довер је утврдио да раса није узрок рата; империјална ривалства преко Пацифика, савез у Европи и јапанска агресија довели су до америчке борбе на Пацифику. Међутим, за разлику од рата у Европи, рат између Јапана и САД јесте „рат без милости“, јер су, као што је поменуто, расне предрасуде дехуманизовале оба противника. Видети шире у: John Dover, War Without Mercy: Race \& Power in the Pacific War, New York: Pantheon Books, 1986.

${ }^{172}$ Као што је закључио Колин Греј, покушаји да се примени логика америчког застрашивања на све националне компоненте у нуклеарној трци у наоружању сигурно ће условити 
Општа теорија стратегије, која игнорише разлике у „локалном контексту“, изазвала је незадовољство међу аналитичарима безбедности и довела до потраге за алтернативним теоријама стратешког понашања. Културолошке теорије су биле једини очигледан избор, тако да су поново привукле присталице у студијама безбедности и изазвале други талас утицаја културних фактора.

Други талас је нарочито показао своју снагу током појачане борбе у Хладном рату са Совјетским Савезом крајем 1970-их и почетком 1980-их. Бројни стручњаци за безбедност износили су став да су САД због своје културне неспособности да размишљају и делују стратешки биле у одлучујуће неповољном положају vis-à-vis Совјетског Савеза. Тако су се појавила два гледишта културолошки оријентисаних стручњака за безбедност. Једни су се усмерили на проучавање различитих организационих култура америчких и совјетских војних снага. Према њима је текућа америчка стратешка теорија рођена у браку између научника и рачуновође, а професионални војник је изгубљен.

Насупрот томе, совјетску војску су видели као Клаузевицеву и операционално оријентисану. Веровали су да ове разлике у америчким и совјетским војноорганизационим културама стављају САД у крајње неповољан положај у вођењу Хладног рата. Друга значајна струја стратешко-културолошког теоретисања о Хладном рату ставила је у фокус својих разматрања америчку и совјетску политичку културу. Неки су демократске САД видели као слабе и неодлучне, јер су имале малу традицију дужег ратовања или суптилног државништва. Пошто су САД могле да се представе и као потрошачко друштво, сматрали су их неспособним за успешно вођење „игре“ у високој политици.

погрешан прорачун уколико особеност сваке компоненте није у потпуности јасна. Слично томе, мало је вероватно да ће америчке теорије ограниченог рата, ескалација, мере против побуне, национална изградња, достићи жељени крај, испунити предвиђене циљеве, осим ако не дође до адекватног усмеравања пажње на локални контекст. Видети: Collin Gray, „What RAND Hath Wrought“, Foreign Policy, No. 4 (Fall 1971), pp. 111-129. 
Са друге стране, Совјетски Савез су видели као уједињену и ауторитарну државу, са дугом традицијом у вођењу ратова и великом умешношћу у високој дипломатији. У оним сегментима друштвене структуре где су САД биле средња класа, потрошачко друштво, Совјетски Савез је био сељачко друштво, са неупоредиво другачијим ставовима поводом сукоба и националних односа. Критичари су били сигурни да ће ове разлике дати предност Совјетском Савезу у Хладном рату.

Међутим, из Хладног рата као победник излазе САД и чини се да су аргументи културолога о том периоду били погрешни. Дакле, упркос прогнозама културолога тог времена о пропасти демократске, комерцијалне и „неклаузевицевске“ САД, оне су очигледно добиле „рат“, и то уз готово исту стратешку и политичку културу која је „изгубила“ рат у Вијетнаму. ${ }^{173}$

Неуспех другог таласа културних фактора који је доминирао током Хладног рата, упркос свему томе, оживео је потрагу за културалним објашњењима о понашању држава у међународном систему. Један од заслужних теоретичара свакако је и Питер Каценстејн, који почиње свој увод за повратак култури у националним студијама безбедности изношењем тврдње како је „тешко порећи да су постојеће теорије у међународним односима жалосно подбациле у покушају да објасне важну револуцију у светској политици“. ${ }^{174}$

Многи научници су веровали да је Хладни рат окончан због унутрашњих промена у Совјетском Савезу у виду економског колапса и демократизације. Други су пак тврдили да је то проузроковано „новим мишљењем“, што је, опет, резултат ширења нове глобалне културе пренете кроз мировни покрет, бригу

${ }^{173}$ Губитак САД у Вијетнаму постао је извор брига поводом недостатка америчке стратешке културе. Ако је култура била у тој мери критиковано објашњење за исход рата у Вијетнаму, како онда објаснити огромне разлике у борби Северних Вијетнамаца и Вијетконга у поређењу са армијом Јужног Вијетнама (коју су подржавали Американци)? Сви су били производ сличне стратешке и политичке културе. Неколико година касније Совјетски Савез, са очекивано ефикаснијом стратешком и политичком културом, није прошао ништа боље у сличном рату у Авганистану.

${ }^{174}$ Peter J. Katzenstein, ed., The Culture of National Security, Norms and Identity in World Politics, New York: Columbia University Press, 1996. 
научника натуралиста или других научних удружења. У сваком случају, заједничко свим овим објашњењима јесте одбацивање реалистичког погледа на међународну политику, који поставља државе у неумољиву утакмицу моћи и безбедности.

Послехладноратовска ренесанса интересовања за културу у студијама безбедности заправо је само одсликавала општији повратак интересовању за те варијабле. Обновљен легитимитет културних варијабли такође се на леп начин спаја са научним интересима за идеје и унутрашњу политику, али и са обновљеном сумњом у опште теорије. Култура је идејна варијабла, а идеје су, између осталог, и у сфери национално̄г и често наглашавају јединственост међу случајевима. Коначно, повратак култури у студијама безбедности неким научницима је интересантан, јер је мање везан за позитивизам - „став да су сва сазнања научна“ - од других приступа у националним студијама о безбедности. ${ }^{175}$

Као што су показала и ранија културолошка истраживања у политичким наукама и последњем таласу културолошких теорија у студијама безбедности замера се што нису формулисали јасну и широко прихваћену дефиницију културе. Заправо, суочавамо се и са другим потенцијалним препрекама при оцени трећег таласа културолошких теорија у студијама безбедности. Једна од њих је да су културне варијабле сложене за објашњење и примену. Затим, неки теоретичари верују да културне варијабле сваки случај претварају у sui generis и зато њихове теорије нису широко применљиве нити их је могуће тестирати на већем броју случајева.

Култура се као централна варијабла јавља у антропологији и психологији тридесетих и четрдесетих година $\mathrm{XX}$ века, а у политичким наукама четрдесетих и педесетих година истог столећа. До средине 1970-их година култура је већ претрпела опадање интересовања у већини друштвених наука, а

\footnotetext{
${ }^{175}$ На делу је, као што смо већ приметили, све веће незадовољство позитивизмом од стране низа научника, а многи га одмах и одбацују. Изражена је и дуга традиција скептицизма у вези са тврдњама модерне науке о друштву, нарочито позитивизма, међу интелектуалним конзервативцима.
} 
као један од главних разлога наводи се то што је израз „култура“ изгубио своју концептуалну јасноћу. Тако је и култура од централне постала маргинална варијабла, углавном зато што је културне варијабле било тешко објаснити и применити. Дефиниције типа „колективно прихваћене идеје, веровања и норме“, које употребљавају теоретичари културе, многи су оценили као широке и непрецизне, те самим тим тешко применљиве.

Други изазов у процени културолошких теорија огледа се у чињеници да се неки нови културолози у студијама безбедности фокусирају на особености појединачног случаја, а не на факторе који су заједнички већем броју случајева, зато што сматрају да је сваки од њих sui generis. Овакве врсте културних варијабли могле би отежати уопштавање јер често производе случајеве који су супротне „претпоставци хомогених јединица“, које сугеришу да случајеви имају довољно значајних упоредивих једнакости.

Основно начело оваквих културолошких приступа огледа се у одбацивању екстерног рационализма (који понашање међу случајевима чини предвидљивим). Ако би то било тачно, онда би ови културолози имали неке систематске елементе на којима би изградили своје теорије. Без систематских варијабли нема предвиђања, а оно је опет централно за друштвене научне иницијативе и не само из теоријских разлога (потребне су нам теорије да формирамо предвиђање како бисмо проверили те исте теорије) већ и у политичкој анализи (теорије које не дају јасна предвиђања од мале су користи онима који дефинишу одређене политике).

Sui generis изазов омогућава нов приступ предмету који је неоправдано и дуго запостављен у студијама о безбедности од стране неких нових културолога. Коначно, Клифорд Герц се суочава са овим предметом на исправан начин и потврђује да је реч о дубоком проблему: „Велика природна варијација културних форми је[сте], наравно, не само велики (и неисцрпан) антрополошки извор, већ и поље његове најдубље теоретске дилеме - како такву варијацију довести у склад са биолошким јединством људске расе. “176 И поред површних разлика, људска бића деле неке фундаменталне једнакости, на основу којих би

\footnotetext{
${ }^{176}$ Клифорд Герц, Тумачење култура 1, Библиотека ХХ век, Београд, 1998.
} 
требало да је могућа формулација теорија које се баве људским понашањем на општем нивоу. Међутим, многи нови културолози у студијама безбедности нису се адекватно изборили са питањем о количини „заједничке“ људске психологије, физиологије и физике која ствара сличан образац понашања.

Сва ова расправа додатно се усложњава увођењем питања о могућности постојања „науке“ о култури. Неки научници верују да је култура подложна систематском учењу, док су неки други, попут Герца, скептични. Наиме, Герц сматра како културолошке теорије нису у стању да обезбеде две ознаке културе: кумулацију и предвидљивост. ${ }^{177}$

Истакнути присталица теорија о култури, већ више пута цитирани Семјуел Хантингтон, такође признаје да су њена „објашњења ... често непрецизна и таутолошка, или обоје, и до екстрема се своде на префињено изражавање у стилу 'такви су вам Французи'“ С друге стране, објашњења културе нису задовољавајућа ни за друштвене научнике, којима време истиче у покушају да докажу да поседују склоности да генерализују. Међу новим културолозима, упућеним у студије безбедности, налазе се модернисти, који верују да су културне варијабле особеност друштвенонаучних студија попут било какве друге варијабле коју користи научник. Присутни су, такође, и непомирљиви антимодернисти, који се залажу за приступ у складу с којим свет не посматрају у смислу дискретно постојећих варијабли чији је независан ефект на варијацију или неслагање мерљив према статистичкој логици.

И поред озбиљне дебате и неслагања о улози културе у студијама безбедности, не може се порећи нити умањити потпуно нов начин третирања културе у овим студијама. Иако теорије о култури тренутно нису подложне уопштавању случајева, не искључује се могућност да временом то постану. Другим речима, можда не могу да пруже опште теорије о понашању свих држава, али могу формулисати теорије о понашању појединих држава у спољној политици за одређени период у тим случајевима.

\footnotetext{
177 Према Герцу, ,антропологија је наука чији прогрес у мањој мери означава савршенство консензуса неголи префињеност дебате. Оно што постаје боље јесте прецизност са којом узнемиравамо једни друге.“ Исто.
} 
Наравно, ниво анализе уплива културе и културних теорија у безбедносно понашање одређених актера може се померити са државе на друштвене групе, регионалне или локалне актере, па све до појединца.

\subsection{1 Крај Хладног рата и стварање нових идентитета укорењених у култури}

Безбедност се, као што смо већ представили, традиционално разматрала у области стратегије и моћи. Након Другог светског рата, под маском стратешких студија које су биле фокусиране на одбрану територије државе, употребом војних и материјалних снага, у оквиру студија безбедности изгледало је тешко да се може размишљати о безбедности у било којим другим појмовима. Међутим, у последње две деценије двадесетог века уочена је појава значајних изазова за нову визију безбедносне и сигурносне анализе. Поред тога што се указала потреба да се прошири аналитички и методолошки план за студије безбедности, истовремено се проширио простор анализе који је укључио питања идентитета, људске безбедности, безбедности животне средине, као и низ других проблема, и створила се разноврсна и резонантна област интелектуалне и политичке дебате.

Крај Хладног рата доводи и до еволуције безбедносних односа, а теоретичари и аналитичари развијају више конструктивистичку анализу, која ће превазићи уска рационалистичка и материјалистичка схватања. Наиме, указују на потребу да се развију софистициране социолошке теорије безбедности, које ће у центар својих анализа ставити питање културе и идентитета. Социјалне конструктивистичке теорије и анализе почињу да заузимају значајно место у савременим студијама безбедности. На тренутак, концепти моћи и стратегије све су се мање третирали у безбедносним анализама и проценама, а изгубили у конструктивистичким студијама безбедности. То је на неки начин оставило значајне импликације на новију историју безбедносних односа и њихове 
будуће путање развоја. ${ }^{178}$ Паралелно са националном безбедношћу и интегритетом државе, постоје и безбедносни захтеви који се тичу идентитета и културе одређених друштава, па чак и локалних заједница или посебних региона. Захтеви се много више тичу претњи.

Још су представници либералног институционализма указивали на свеобухватно промишљање о безбедности, истицање значаја социјеталне безбедности, а у њеном оквиру и важност етничко-верске самобитности. Нови правац студијама безбедности дала је и Копенхагенска школа представљајући теорију секуритизације, идеју о безбедносним секторима и теорију регионалног безбедносног комплекса. Идеја безбедносних сектора представљала је проширење концепта безбедности са војних на политичке, економске, социјеталне и еколошке аспекте. ${ }^{179}$

Социјетални сектор и социјетална безбедност сачињавају сегмент о којем се највише расправљало и који и данас изазива највише полемика и супротстављених мишљења. Социјетална безбедност се може представити као способност друштва да очува своје суштинске особине услед променљивих околности и упркос могућим или стварним претњама. Ова безбедност је угрожена онда када заједница доживљава претњу као нешто што угрожава њен идентитет, а већ је познато да се идентитет дефинише као скуп идеја и пракси које одређене појединце идентификују као припаднике једне друштвене групе. Национални идентитет се јавља као најзначајнији референтни објект социјеталне безбедности и он у себе укључује одређени смисао политичког

${ }^{178} \mathrm{У}$ многим разматрањима, деценију након Хладног рата, наступио је миран период у којем су се власт и њени императиви повукли из средишта пажње теоретичара и аналитичара безбедности, а значај норми и вредности, али и утицај културе и демократије као меке моћи, заузели су централно место на међународној позорници. У новом миленијуму, међутим, долази до новог преокрета и поново на сцену ступају реалполитика и доминација тврде моћи.

${ }^{179}$ Као главни аналитички инструменти користе се сектори, који означавају специфичну логику и тип интеракције између јединица (одређених субјеката). У овом контексту војни сектор подразумева односе моћи, политички односе ауторитета, економски економске односе, еколошки односе човека и природе, а социјетални сектор односе друштвених група. 
заједништва, заједничких институција и одређених права и дужности за све чланове заједнице. Такође, он обухвата и дефинисани социјални простор и означену ограничену територију са којом се чланови заједнице идентификују и за коју гаје осећаје припадности.

Поред националног идентитета, као референтни објекти социјеталне безбедности издвајају се и аспекти везани за религију и род. Пошто и род и религија имају посебно изражене и специфичне карактеристике и својствену динамику, издвајају се и као посебни сектори. Када се говори о безбедности неке верске групације, мисли се на одбрану вере и одбрану религијске заједнице. Предузимање одређених (не)безбедносних активности у име религије указује на то да постоји претња не за заједницу, већ за саму веру. Уверљив пример овакве безбедносне активности представљају бомбаши самоубице. Концепт секуритизације би се у том смислу односио не на заједницу и њен идентитет, већ на секуритизацију одбране вере. Како тврди један од теоретичара концепта секуритизације, Оле Вивер, проучавање динамике социјеталног сектора свело би религију на религијску заједницу, што би искључило њен веома битан трансцендентални елемент.

\subsection{2 Однос културе, идентитета и безбедности}

Када се говори о безбедности, готово сви концепти издвајају две димензије: изворе претњи и референтне објекте безбедности ка којима је претња упућена. У односу на традиционална схватања, код савремених тумачења извори се шире од политике и војске ка економији и животној средини, све до друштва у целини, док се друга димензија продубљује премештајући се са националног на међународни ниво и ниво друштвених група и човека као појединца. Такође, постоји виђење концепта безбедности са позитивистичког и негативистичког aспекта. $^{180}$

\footnotetext{
${ }^{180}$ Adrian Hyde-Price, ,Beware the Jabberwock!: „Security Studies in the Twenty-First Century“, in: Gartner, Heinz, Hyde-Price, Adrian, Reiter, Erich (eds.), Europe's New Security Challenges,
} 
Традиционална схватања безбедности имају тенденцију више ка негативном облику, који подразумева избегавање физичке претње. У том смислу је безбедност нешто опипљиво, видљиво и мерљиво. Тако конципирана брига о безбедности подразумева мобилисање физичких ресурса у циљу супротстављања спољним претњама, гарантујући територијални интегритет и очување домаћих институција, што значи и приближно изједначавање националне безбедности са војном одбраном. С друге стране, позитивна безбедност се схвата као однос, што је заправо људска конструкција која се огледа у стабилном или променљивом колективном идентитету. У овом случају небезбедност се разуме као претња вредностима или идентитету.

Са становишта идентитета, предмет безбедности се посматра више као динамичан процес којим се идентитети остварују у различитим контекстима, или кад се и како треба бавити овим проблемима у друштву под рубриком безбедност. То су и ситуације када се лако може исполитизовати питање идентитета и тиме смањити капацитети за моменте преговарања, флексибилности и вишеструкости у односу на околност да ли је то заиста безбедносно питање.

Управо у овом делу рада указала се прилика да се мало боље разјасни у којим су релацијама и на који начин одређени теоретичари и представници појединих теоријских праваца у оквиру студија безбедности посматрали културу, идентитет и безбедност - и, наравно, какво је наше виђење тог односа. Наиме, безбедност, култура и идентитет чине три концепта која су дубоко испреплетена на многим различитим нивоима и не могу се одвојити. Међутим, са овом тврдњом не би се сложили баш сви теоретичари.

Реалисти и неореалисти игноришу улогу културе и идентитета у сфери безбедности. Наиме, они сматрају да су све државе унитарне, усмерене су ка опстанку, а самим тим, без обзира на то да ли су демократске или тоталитарне, испољавају конкурентско понашање. Интереси држава су униформисани, а универзални циљ је да се преживи. Према овим теоретичарима однос између

London: Lynne Reinner Publishers, 2001, p. 29; према: Младен Бајагић, Основи безбедности, Криминалистичко-полицијска академија, Београд, 2007, стр. 14. 
културе, идентитета и безбедности врло је слаб. Међународни систем се иначе посматра као свет анархије, а државе морају да се ослоне на војне снаге како би испуниле функцију самоодржања. Унутар таквог оквира, капацитети државе се мере сопственим војним способностима у односу на противнике.

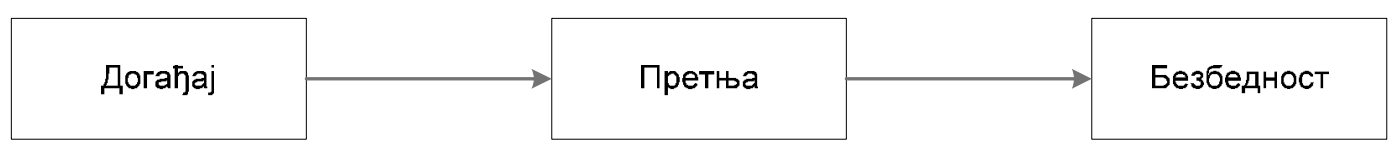

\section{Схема 3. Реалистичко виђење безбедности}

Према групи аутора (Џеперсон, Вент, Каценстејн), ${ }^{181}$ догађај се може сматрати претњом у зависности од тога како се дефинишу национални интереси, што заузврат доводи до одлука које представљају одговарајућу безбедносну политику и адекватне акције које ће се предузимати у том смислу. Дакле, реалистичко виђење безбедности (схема 3), не узима у обзир друштвене факторе, посебно оне који се односе на национални идентитет и норме (културне), који могу утицати на опстанак једне државе, понашање и њен карактер или обележја.

Узимајући у разматрање конструктивистички приступ (схема 4), уочавамо да они узимају у обзир не само чињеницу да национални идентитет има утицај на норме и културу, већ и то да култура одређује формирање националног идентитета. Тако се добија и ревидирани оквир безбедности.

${ }^{181}$ Jepperson, R. L., Wendt, A., Katzenstein, P. J., „Norms, Identity and Culture in National Security”, y: Katzenstein, P. J. (yp.), The Culture of National Security: Norms and Identity in World Politics, Columbia University Press, New York, 1996. 


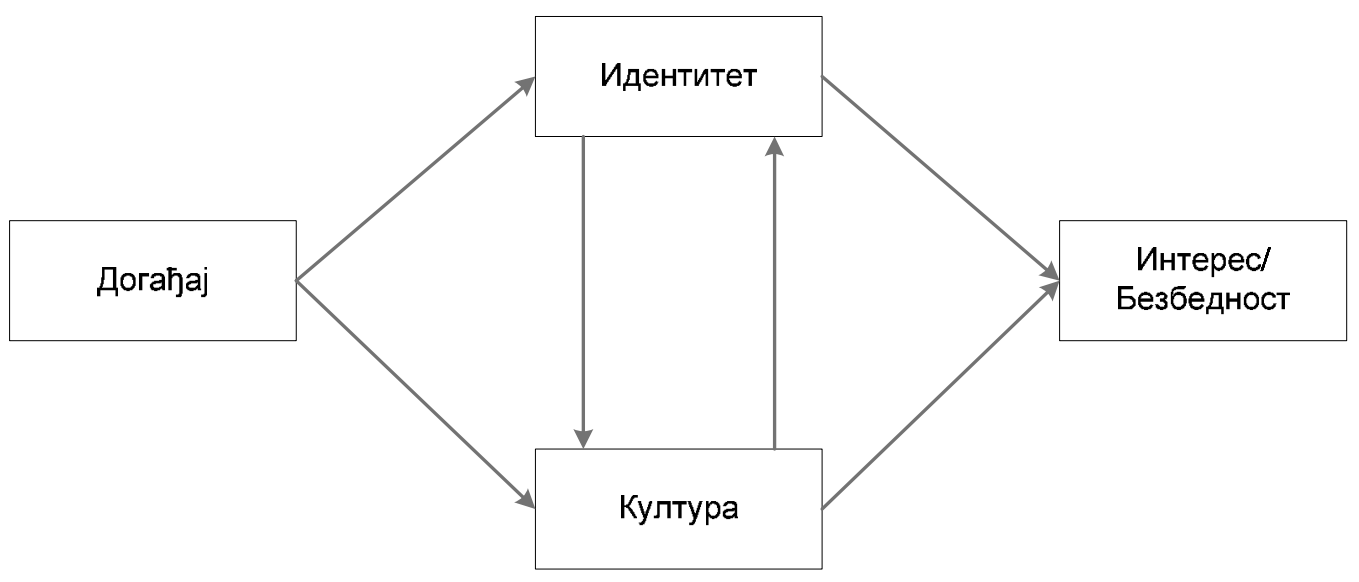

Схема 4. Конструктивистичко виђење безбедности

Поједини аутори, попут Вента и Кембела, имали су сличан приступ, али су желели да нагласе важност идентитета, пре него норми и културе. ${ }^{182}$ Чак и према тумачењу Каценстејна, норме и култура се у најбољем случају могу тумачити као контекст безбедносне политике. Дакле, као независна променљива се уводи идентитет. Стога се може говорити о донекле ревидираном виђењу безбедности (схема 5) у односу на конструктивистичко.

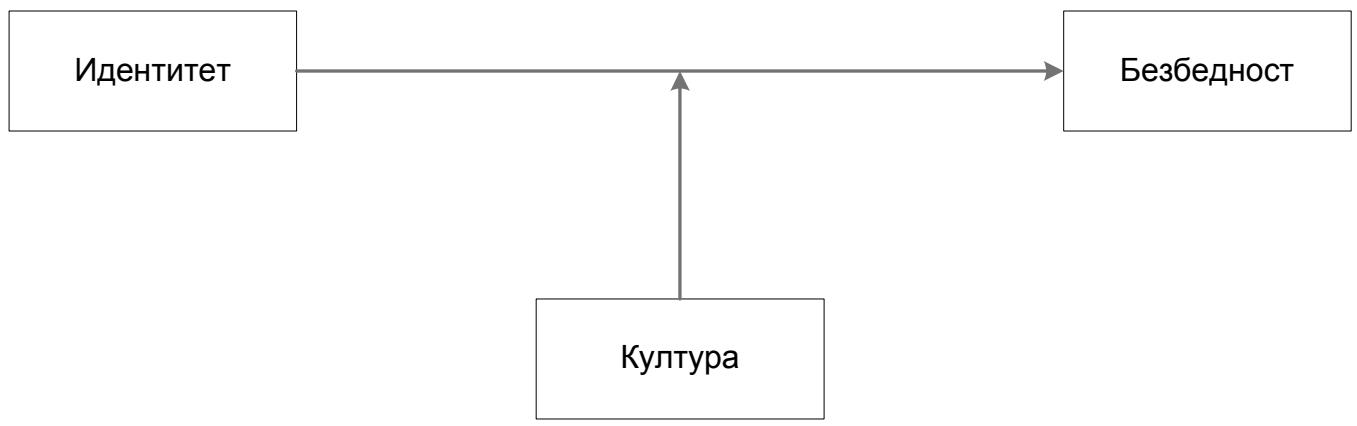

Схема 5. Ревидирано виђење безбедности

182 Alexander Wendt, Collective Identity Formation and The International state, American Political Science Review, vol. 88, No. 2, 1994; David Campbell, Writing Security: United States Foreign Policy and the Politics of Identity, University of Minnesota Press, Minneapolis, 1998. 
Мек Свини се укључио у теоријску расправу, делимично оспоравајући ставове претходних аутора, нарочито у делу где претерују са објашњењем корисности перцепције, било у облику идентитета или културних фактора, а самим тим је предложио да треба да се узму у обзир национални интереси (схема 6). Наиме, иако су претходна виђења покушала да надмаше реализам, донекле су „пренаглашавала“ објашњење корисности идентитета и интереса, а опет, неоспорно је да идентитет и интереси међусобно изграђују једни друге и тиме заузврат одлучују како се безбедност доживљава. ${ }^{183}$

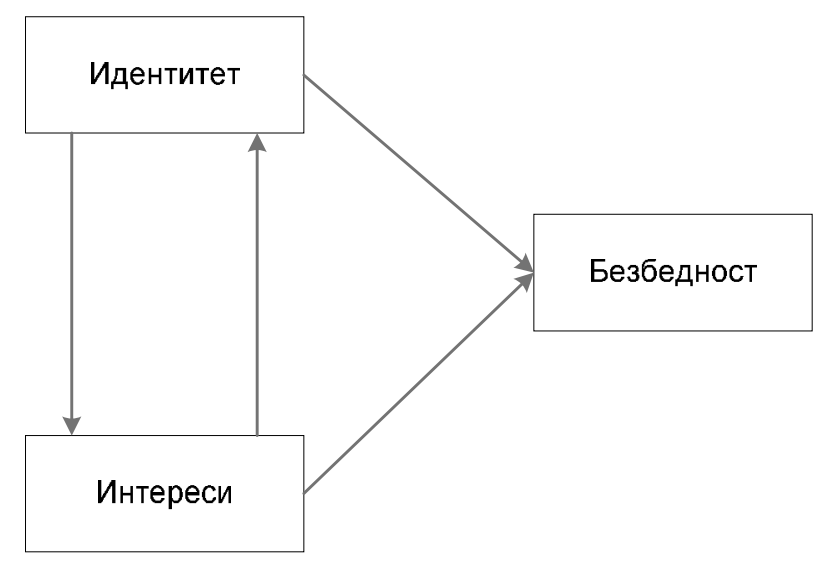

\section{Схема 6. Мек Свинијево виђење безбедности}

Иако се генерално сви аутори слажу да је идентитет основа за интересе и безбедност, постоји извесна резерва према томе како интереси могу повратно утицати на избор идентитета. ${ }^{184}$ У том смислу се може размотрити и идеја да интереси буду у најбољем случају посредна променљива, која може да погорша или ублажи узрочну везу између идентитета и безбедности, а не независна променљива (схема 7).

183 Bill Mc Sweeney, Security, Identity and Interests: A Sociology of International Relations, Cambridge University Press, 1999.

${ }^{184}$ Након свега, интерес је механизам који Европска унија користи као притисак на Ирску да прихвати мировни споразум у Северној Ирској, али који не може бити универзално важећи. 


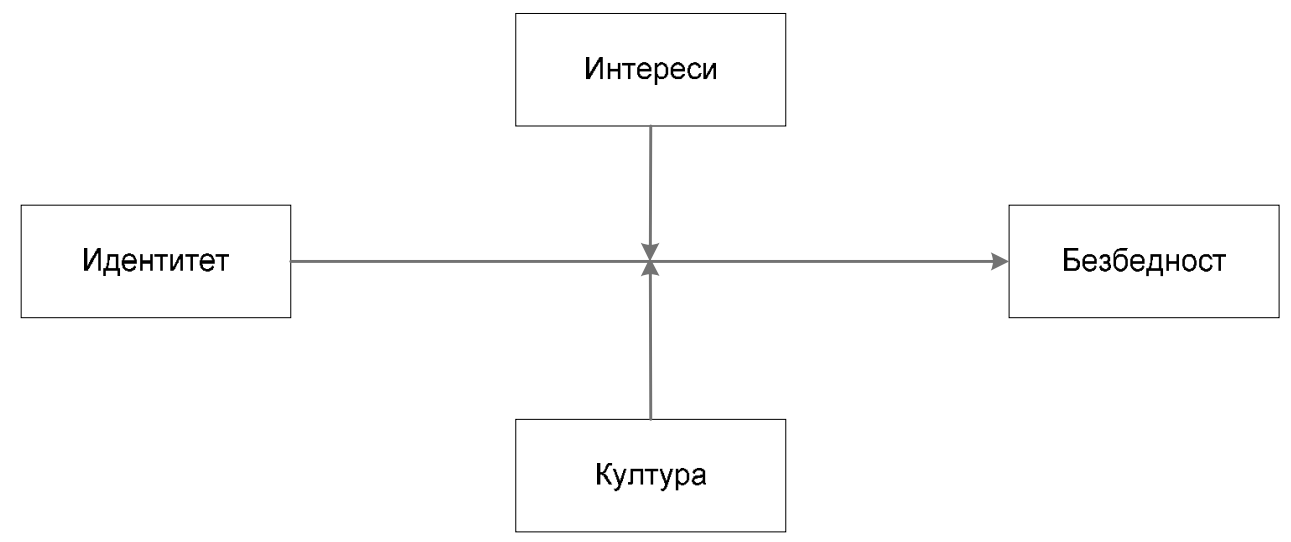

Схема 7. Ревидирано Мек Свинијево виђење безбедности

На основу свега изреченог, покушали смо да дамо своје (шире) виђење односа културе, идентитета и безбедности, уводећи још неке појмове у ову анализу (додајући култури и безбедности заједнички атрибут - национално). Зато предлажемо следећи схематски приказ.

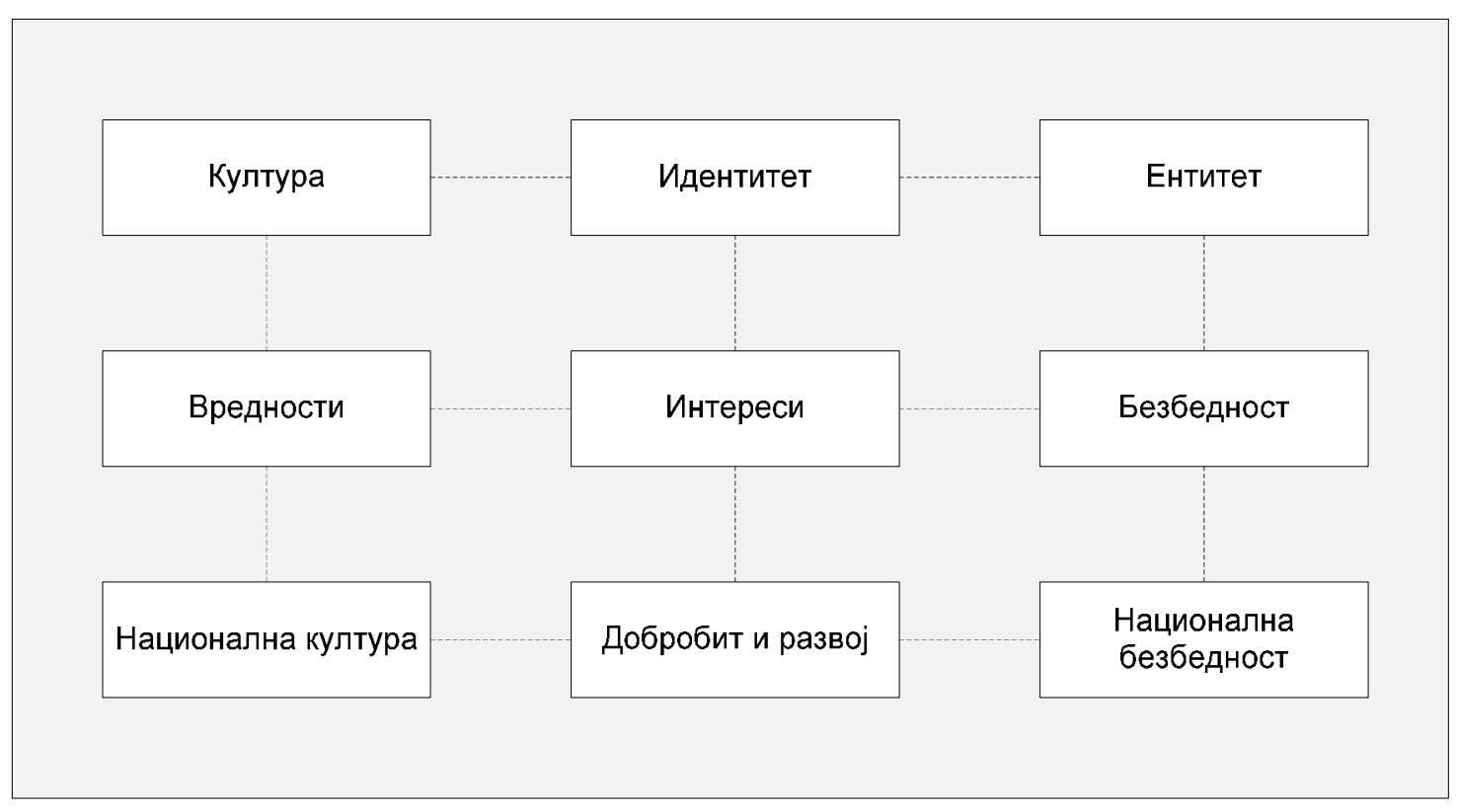

Схема 8. Културолошки аспект националне безбедности 


\subsection{3 Култура и систем вредности као основ сарадње у безбедности}

Још од најранијих времена била је на делу сарадња између држава када су у питању безбедносни проблеми, али је углавном била краткотрајна и вођена тренутним интересима, што су подразумевали заједнички разлог или опасност која је имплицирала стварање савеза. Овакво удруживање снага често није подразумевало вредносну блискост, као предуслов за заједничку бригу о безбедности. Међутим, временом су се ствари промениле. Услед редефинисања замисли безбедности јавила се и потреба да се на другачији начин осигурају властита безбедност, али и опстанак човечанства.

На основу антрополошких истраживања, може се тврдити да је за опстанак људског рода, сарадња најфундаменталнија људска особина. Она је универзалнија од конфликта и рата, јер нема људске групе која није развила неки облик сарадње, док је сукоб у виду ратова потпуно непознат у неким „примитивним“ друштвима (сетимо се примера Ескима̂). ${ }^{185}$

Бери Базан је имао визију гледајући много унапред, када је рекао да се ни о властитој безбедности не може ваљано старати ако се, претходно, не узму у обзир безбедносни интереси суседа и осталих народа и држава. ${ }^{186}$ Тако је пажљивију анализу заслужио управо огроман пораст сарадње успостављене између земаља Евроазије и Северне Америке у другој половини XX века. У питању су државе чије је начело политичке организације либерална демократија и које, према неким мислиоцима, једине могу бити јамац поштовања, очувања и унапређења појединачне безбедности, људских права, односно тзв. људске безбедности.

\footnotetext{
${ }^{185}$ О овоме се може више сазнати у делима Маргарет Мид и А. Гардинера [Alan Henderson Gardiner].

${ }^{186}$ Buzan, Barry, People, States and Fear, second ed., Harvester Wheatsheaf, London, 1991.
} 
Како је нагласио Ричард Коен [Richard Cohen], само они народи који имају заједничке вредности и циљеве могу да образују један колективни систем безбедности заснован на сарадњи. ${ }^{187}$

Значај међународне сарадње у области безбедности, посебно оне која се испољава кроз мултинационалне облике и институционално удруживање, огледа се у томе да може представљати најделотворније средство за превазилажење насилних сукоба у односима народа и држава. Политичка, економска и културна сарадња заснована на односима „сложене међузависности“, у условима огромног техничко-технолошког напретка, налази се у средишту размишљања представника̂ либералног институционализма.

У унутрашњим односима је, захваљујући сарадњи, могуће достићи правду, заједништво, демократију и друштвени напредак. У сопственом друштву људи могу да се идентификују на више начина: с обзиром на друштвену улогу, везе и задатке, у складу са односом према заједничким митовима и спремношћу за заједничко деловање. Те идентификације имају међу собом доста заједничког; људи који припадају једном друштву и који чине једну културу могу запазити аналогне појаве код особа које припадају другом друштву и које чине посебну културу.

Ово су аналогије функционалног типа, али могу проистицати из постојања заједничког скупа вредности. Заједнички канон вере, аналогија у спровођењу религијске праксе, свест о повезаности у оквиру заједнице верника, исти узор понашања и третирање јавне сфере само су неки од примера на које се људи позивају, тј. одређују према једном истом систему вредности. Заједнички елементи те врсте система вредности не доводе до уједначавања друштава; она остају веома различита и углавном антагонистичка.

187 Према истом теоретичару, недемократски режими и државе које представљају тзв. демократије са смоквиним листом могу у интересу безбедности и стабилности сарађивати, али краткорочно и са посебним циљевима. Видети: R. Cohen and M. Mihalka, Cooperative Security: New Horizons for International Order, „The Marshall Center Papers“, No. 3, 2001. 
Међутим, дистанца не мора да буде тако велика. Страност може бити превазиђена захваљујући препознавању неке заједнице. То осећање не отклања конфликт, непријатељство, антипатију, предубеђења која су својствена за различита друштва. У европском простору веома важан елемент наткултурне заједнице чини настојање да се превазиђу управо та осећања страности, непријатељства, ксенофобије и слична. Управо је Јан Кјенјевич у Уводу у историју ичивилизације Истока и Запада нагласио да постоје два услова за успостављање односа сарадње и пријатељства између две различите културе. Први је развијена свест о сопственом идентитету и сагле́дању различитости Других, а потоњи се односи на подударност система вредности које ствара свако друштво.

Веома битно за однос између људи различитих култура јесте учешће у заједничком схватању вредности. Слобода, истина и љубав представљају те вредности када је у питању европска цивилизација. ${ }^{188}$ Заједничке вредности стварају основ за „заједничку“ културу, а самим тим пружају шансу за дијалог. Дијалог између људи ствара мрежу веза у којој се обликују заједнички доживљаји и остварења вредности, осећање повезаности и свест о блискости. А све заједно може много допринети да сви буду безбедни или бар безбеднији.

188 Пример Европе није универзалан. Изван Европе се вредности приказују као битно различите; тамо су се цивилизацијске припадности формирале на знатно другачији начин. Ако прихватимо да су оне настале у религијским системима, онда се може поставити питање не заклањају ли очигледне разлике културно јединство. Љубав, истину и слободу могли бисмо третирати као универзалне вредности којима религије, а касније и културе, дају различита својства. Зато треба бити веома опрезан приликом третирања хришћанских вредности као универзалних вредности повезаних са човечанством. Различитост смисла и израза вредности одлучује о другачијем начину изражавања припадности и различитости односа према Другима. Видети више о томе у: Јан Кјенјевич, Увод у историју иฺивилизације Истока и Запада, Службени гласник, Београд, 2011. 


\subsection{4 Култура као безбедносни изазов}

Још од времена настанка савремених националних држава постало је јасно да културе могу бити обликоване конструкцијама и свесним политикама, али да такође могу чинити оруђе помоћу којег можемо обликовати људе, њихово мишљење, ставове, предрасуде, емоције, обрасце понашања. Као што смо већ нагласили, Семјуел Хантингтон је у Сукобу иивилизаиија представио како култура и културни идентитет обликују моделе кохезије, дезинтеграције и сукоба у свету након Хладног рата. Управо је прелазак источних социјалистичких земаља из једног система у други актуелизовао и на специфичан начин отворио дискусију о култури, културним специфичностима народа и држава бившег социјалистичког уређења, затим о подстицајима или препрекама транзицији, чије порекло може бити не само политичко и економско него и културно. Тако се и одговори на питање који су узроци неуспеха у транзицији често траже у сфери културе.

Такође, важно је приметити да се суровост ратова на одређеним просторима објашњава управо специфичном природом културе која ту пребива. Типичан пример такве тврдње чини простор Балкана, која је у својој основи, морамо признати, прилично оптерећена стереотипима и предрасудама. Балканско полуострво, осим тога што је историјски простор на којем су настале бројне цивилизације, такође је подручје које одликују етничка, религијска и културна хетерогеност. Управо је однос према тој хетерогености у бројним анализама навођен као главни узрок ратова који су се водили на овом простору, али и узрок немогућности потпуне аутоидентификације региона и истрајавања на чврстом културном идентитету.

За народе Балкана постоји још једна „специфичност“, а то је да митови и архетипи нису само део културе сећања у колективном памћењу народа, већ су и део савремености. Притискају савременике и утичу на њихове културне оријентације, али и социјалнопсихолошко деловање. Неки аутори се слажу да није исувише сурова констатација ако се каже да балкански народи више 
полажу на ратничку културу и културу насиља, него на културу мира и културу рада. ${ }^{189}$

Уколико предмет анализе усмеримо на другу димензију, може се говорити о насиљу као моделу понашања и садржинском делу културног обрасца које једно друштво поседује. Физичко кажњавање деце може бити део културе насиља одраслих, а негде се примењује и као метода васпитавања у образовним установама и породици. Постоје социјалне и културне норме које су део свакодневице у многим друштвима, а само неке од њих јесу: одобравање насиља као нормалног начина разрешавања проблема, прихватање самоубиства као индивидуалног права, давање предности правима родитеља над добробити детета, подстицање мушке предоминације, одобравање насиља полиције над грађанима, подстицање политичких конфликата, неприхватање права на различитост и многе друге. Неке од њих су део и легитимне правне норме.

Културно насиље ${ }^{190}$ је такође један аспект културе који обухвата симболичку сферу наше егзистенције (религија, идеологија, језик, уметност, емпиријске и формалне науке), која може да се користи ради оправдања или легитимисања директног или структурног насиља. Наравно, мисли се на аспекте културе, а не на читаве културе. Тешко је и замислити да се читаве културе могу означити као насилне. Међутим, могу се замислити културе које имају не само један него и читав скуп аспеката који су толико насилни, обухватни и различити да

189 Љубиша Р. Митровић, „Омладина Балкана и култура мира у контексту савремених структурних промена“, Зборник радова Омладина Балкана између насиља и културе мира, Центар за социолошка истраживања Филозофског факултета у Нишу, Ниш, 2007.

190 Оснивач Студија мира, Јохан Галтунг, аспекте културе који легитимизују насиље назвао је културним насиљем. Културно насиље се може објаснити и као културом уграђена пракса и претпоставка доминације над женама у већини друштава и генерално прихватање насиља као средства одржавања те контроле, чак и одбране мушкости. Пре него што се неке ствари означе као „културни и традиционални“ облици насиља, треба разумети да је свеукупно насиље над женама културалне природе, или бар опстаје онолико дуго колико га култура (у облику породице, заједнице, пријатеља, колега, религије) генерално прихвата. Ово је прави културни изазов насиља над женама. Према: Шарлот Банч, Поглед на хуману безбедност и феминистичка перспектива људских права, људска безбедност, тематски број „Род и људска безбедност“, Београд, 2005. 
обухватају читаве културне домене и ту је готово неизбежно прећи са концепције о случајевима културног насиља на концепцију о насилној култури. ${ }^{191}$

Култура као безбедносни изазов, али и ризик, носи, условно речено, две конотације - с обзиром на природу ризика да може донети нешто добро или нешто лоше, и култура се може разматрати као снага која раздваја или као снага која уједињава. За културу се заправо може рећи да има два лица: рушилачко и стваралачко. Рушилачко лице културе је грубо, склоно затварању заједнице и разарајућем односу према унутрашњем и спољном свету. У том свету се граничи са ксенофобијом, расизмом или национализмом и заузима другоразредно место у хијерархији поретка моћи - иза политичке, економске или војне моћи.

Стваралачко лице културе отвара заједницу, гради и обогаћује свет. У поретку моћи стваралачка култура ставља културу на прво место. Стваралаштво иначе представља уношење смисла у људски живот и постојање, односно непрекидну борбу са унутрашњим и спољашњим границама. Када се људи суочавају са изазовима из окружења који захтевају одговоре и решења, једна од функција културе јесте да обезбеди услове који ће омогућити најбољи избор између алтернативних решења.

Ова суштинска улога културе не сме бити потиснута, а ни њени капацитети не смеју бити оштећени у обезбеђивању адекватног одговора на развојне промене или изазове у друштву. Тако, на пример, економска активност не сме бити одвојена од сопствене културне креативности и иновативности и самим тим производни процеси у друштву не морају бити зависни од страних инвестиција, кредита и сличних ресурса. На тај начин се јачају везе између културног стваралаштва друштва и тражења решења за проблеме са којима се суочава и истиче значај културе супротан ономе где се она јавља као извор насиља и бројних облика деструктивног понашања. Култура, а самим тим и

${ }^{191}$ Јохан Галтунг, Мирним средствима до мира. Мир и сукоб, развој и цивилизација, Службени гласник, Београд, 2009. 
друштво, иду напред захваљујући стваралаштву, али не треба заборавити да постоје и непожељни облици стваралаштва.

\subsection{5 Култура као исходиште или упориште безбедности}

Ако култура обухвата материјалне и духовне тековине помоћу којих чланови једног друштва решавају проблеме своје егзистенције и задовољавају широку скалу људских потреба или интереса (па и потребе за безбедношћу), с правом, у обе димензије културе, можемо потражити и изворно исходиште или упориште безбедности. И материјалне и духовне форме културе служе за самоизражавање личности; пружају човеку могућности да реализује своје стваралачке потенцијале. Ако материјална култура у својој конкретности оваплоћује степен практичног освајања природних сила и материјала које човек остварује, онда духовна култура представља унутрашње богатство свести, степен развијености самог човека. Духовна и материјална култура нису статичне, нису учвршћене једна поред друге, него се изражавају једна помоћу друге, постоје само у процесу људске животне активности, прелазећи једна у другу.

\subsubsection{1 Материјална димензија}

Материјална димензија културе обухвата онај део културе који се изражава кроз артефакте - дакле, било који предмет који је заједница створила - или, једноставно, представља технолошки аспект људског деловања. При том, сваки предмет као производ материјалне културе има: облик, функцију, материјалност, значење, вредности, задовољавање потребе. Још шире, можемо рећи да материјална култура обухвата средства, технике, методе и процесе који се користе у одређеним културама за производњу роба и услуга, као и њихову дистрибуцију и потрошњу. Ова димензија културе је резултат технолошке и економске развијености једне земље, а манифестује се кроз расположивост и квалитет основне економске, социјалне, финансијске и маркетиншке инфраструктуре и директно је повезана са друштвеним стандардом. 
Као што можемо да приметимо, материјална димензија културе се у доброј мери ослања на научно-технолошка достигнућа, која значајно помажу човеку да мења своју околину, прилагођава себи не само природне већ и друштвене услове живота. У процесу хуманизације људског живота, тј. борбе за егзистенцију и квалитет живота, у развијању производње и организације друштва, развијању интелектуалних способности човека и потенција људске природе, техника има битну улогу. Штавише, техника се представља као инструментални аспект културе.

Развој науке и технике стратешко је питање за сваку земљу. Оне су основа на којима једно друштво ствара нова материјална добра и врши услуге како у цивилном, тако и у безбедносном домену. Неке гране науке и технике имају посебан утицај и битне карактеристике за развој друштва, али и за опстанак друштва. У питању су информационе технологије, биотехнологије, космичка технологија, микротехнологија, нанотехнологија и сличне.

Ако се осврнемо само на информациону технологију, може се запазити перманентан утицај информационе технологије на уређење модерних држава. Практично сви подсистеми једне савремене државе почивају на информационим технологијама: организација државне управе, снабдевање водом и енергијом, саобраћај, банкарство и финансије, трговина и све друго што је део друштвених и привредних активности. Савремени ратови се воде и у информационом простору [cyberspace], тако да смо добили и потпуно нову димензију ратовања. ${ }^{192}$

192 Нова врста рата - информациони рат - обухвата операције над информацијама које се спроводе да се заштите сопствене информације или информациони систем. Информациони рат обухвата различите активности, као што су психолошке операције, војне варке, електронски рат, физички и информациони напад, различите одбрамбене активности и програми. Од информационог можда још бољи пример може бити информатички рат, који, користећи информатичке и друге софистициране системе, значајно утиче на ток и резултате рата. При том се одвија у компјутерским мрежама (интернет), упадом, продајом и преносом заражених програма, злоупотребом хардвера и софтвера рачунара, злоупотребом информација и сличним поступцима. Када се примењује у војној технологији и системима (противваздухопловне одбране, системи за навођење ракета и сличне технологије), јасно је које то последице може изазвати током ратних дејстава. 
Техника и технологија спадају и у средства моћи, која могу бити узрок сукоба и надметања између земаља или других центара моћи у свету. Као постојани ресурс привредног развоја, војне и националне моћи, оне повећавају могућност да успешније одврате потенцијалног агресора, али и да прете другим државама. Технолошки развој има изузетно важан утицај на безбедност и одбрану сваке земље, и то не само због сталног прогреса у домену војних технологија, већ и због снажне дифузије нових технолошких открића у областима економије, друштва и државе. Дубок продор нових производа технолошког развоја у све области живота допринео је и подизању стандарда живљења. Кључна одредница двадесетог века гласи да је то време „техничке цивилизације“, а крајем тог века и данас у трећем миленијуму, човек је постигао да на свакој тачки Земље живи не у непосредном окружењу природе, већ у техносфери. Тако конституисана техносфера дубоко мења са́мо друштво и повратно утиче на културу, на људске индивидуе и њихове потребе, начине социјализације, облике рада, комуникације, учења, стваралаштва, коришћења слободног времена и тако даље.

Техносфера је интегрални део социјалне организације, којим се остварују нови квалитет или нови начин људске егзистенције, у сталном човековом напору да превазиђе физичку борбу за опстанак, да се прилагоди или осамостали у односу на природне силе и природно окружење. Захваљујући њој, такође, омогућава се производња средстава за живот и за задовољење основних потреба чланова друштва, али, како с временом постаје све софистициранија и нуди све више могућности, она данас добија и комплексније функције. ${ }^{193}$

Такође се може рећи да је у другој половини XX века човек постао у великој мери зависан од техничких апарата и технолошког умећа, потискујући остале

\footnotetext{
193 Она, пре свега, постаје кључни чинилац организације система комуникација помоћу којих се преносе искуство и културне вредности на нове генерације; она битно утиче на модусе интеракције унутар друштва и на квалитет функција друштвеног система, на степен интеграције друштва, на развој културног или интелектуалног стваралаштва, индивидуалне и колективне сензибилности и тако даље. Видети: Триво Инђић, Технологија и културни идентитет, Службени гласник, Београд, 2009, стр. 89.
} 
могућности људског стваралаштва и богатство других релација на којима почива човечанство.

Свако друштво хијерархијски класификује културне тековине и вредности. Модерно друштво, посебно оно продуктивистичко-конзумеристичког карактера и утилитаристичке оријентације фаворизује научно-технолошку оријентацију и достигнућа технике као примарног медијума кроз који се перципира културни систем у целини. Међутим, ова тврдња отвара и неке дилеме: тачно је да техника и технолошки напредак омогућавају човеков развој и шири простор, као и богатство људске слободе, али они сами увек остају тек средство тог напретка, те слободе, а не са̂м напредак, односно слобода. Злоупотреба тог средства, односно његово присвајање за потребе појединачних интереса или доминације, уочава се као драматична опасност за сваки напредак, слободе, па чак и опстанак човека као врсте. ${ }^{194}$

\subsubsection{2 Духовна димензија}

Културу као упориште безбедности можемо представити и кроз њену духовну сферу, на основу које се може разложити на компоненте као што су: начин живота, комуникација, рад и стваралаштво. Тиме прихватамо и становиште по којем се култура одређује као збир различитих норми понашања, веровања, начина комуникације, система вредности - свих оних историјски израслих експлицитних и имплицитних животних образаца који у свако време делују као потенцијални водичи у делатностима и понашању људи као чланова

194 Један пример може бити алармантно стање природне средине, које је настало као последица бројних злоупотреба природних ресурса током индустријске револуције, погрешног уверења да су ти ресурси неисцрпни и става да је човек господар природе. Други пример може бити неслућен развој ратних технологија, милитаризација знања и технике. Технолошка надмоћ и огромна улагања у војни буџет, пре свега САД, произвели су жељу за глобалном доминацијом, изазвали трку у наоружању и настојање других земаља да што више инвестирају у ратну технику. Као да једини осећај сигурности у савременом антагонистичком свету, како у малим тако и у великим државама, може пружити поседовање тзв. апсолутног оружја - интерконтиненталних пројектила с нуклеарним бојевим главама. 
друштвених заједница, улазећи у темеље њихових институција и њиховог погледа на свет. ${ }^{195}$

Духовна култура није никакав самосталан, издвојено егзистирајући део културе. Наиме, изван духовног живота и изван свесне људске активности, култура уопште и не постоји. Ниједан предмет не може да буде укључен у људску праксу без његовог осмишљавања, без посредства извесних духовних компоненти: знања, навика или специјално припреманог перципирања. То се најбоље види у односу уметничких дела и компликованих техничких уређаја. С друге стране, духовна култура - идеје, теорије, имагинације, фантазија могу да егзистирају и да се преносе само у материјалној форми.

Култура изражава стање духа једне заједнице, а симболи и вредности које производи дају значење животу. Циљ културе није само трагање за знањем (иако је веома важна компонента, посебно када говоримо о безбедности и небезбедносним појавама или опасностима), већ и ширење погледа на свет, интелигентно учешће, корекција квантитативног развоја кроз квалитативно побољшање, усвајање нових вредности како би се разумео свет, који се мења брже него икада у прошлости.

Сваки појединац и свако друштво одређеним активностима усваја вредности које му помажу да води свој живот. Оне треба да садрже циљеве који утичу на „пречишћавање“ карактера (када је у питању појединац) или изградњу стабилног друштвеног „ткива“, које ће снагом идеја и прихваћених вредности обезбедити снажан темељ за посвећеност променама у друштву. Одрживе заједнице се одликују осећајем солидарности, који свима обезбеђује да имају достојанство и самопоштовање.

195 Ранко Бугарски, Језик и култура, Библиотека XX век, Београд, 2005. 
Појам „духовно“196 се разнолико дефинише у теорији, али постоји један заједнички именитељ. Он подразумева феномен који није материјалне природе, али припада царству идеја, које су настале у главама људи, и то посебно оплемењујуће идеје. Људи су развили своје идеје и предузели одређене активности у циљу побољшања материјалног света у којем живе. Духовна димензија је, према томе, најзаслужнија за обликовање активности људи и начина живота, а она обухвата филозофске, религиозне, моралне и политичке идеологије, које имају дубок утицај на физичко, психичко и социјално благостање људи.

У ово разматрање можемо укључити и заједнице, које такође делују у складу са својим системом вредности, ставовима и обичајима. Њихови вредносни системи се могу изразити на различите начине, као што су религијска веровања и праксе, политичке идеологије, морална осећања, национална, племенска или друга врста групне солидарности, са жељом да овековечи локалне и породичне традиције и културно наслеђе или бригу за будућност. ${ }^{197}$

Духовна димензија културе као исходиште безбедности има специфичан одраз У ратничкој и/или војничкој култури, израженој кроз посебан поглед на рат, однос према непријатељу, према победи и поразу у ратном окршају. Војничке

196 Духовност се може означити као лична потрага за разумевањем одговора на крајња питања о животу, о смислу, о односу свето̄г и трансцендентно̄г, што може (али не мора) да води развоју верског обреда и формирању заједнице или проистиче из њих. Такође се истиче да духовност може бити широка „суштински људска, лична и међуљудска димензија, која интегрише и превазилази културне, верске, психолошке, социјалне и емоционалне аспекте особе“.

197 Својевремено је Владимир Карић, признати српски етнограф, правник и географ, дефинисао народни дух и карактер као „оне душевне белеге, које се при упоређивању једног народа с другим, истичу као юегове нарочите особине, и за које можемо узети да се физичким расплођавањем и друштвеним додиром одржавају у снази, непрекидно, кроз већину појединаца, онда морамо, хтели не хтели, узети и то, да дух народни стоји у вези са земљописним, народописним, историјским и културним елементима и да је према првоме $у$ зависности, а према осталима у односу наизменичнога утицаја“. Видети: Владимир Карић: „Народни дух и осећање“, у: Карактерологија Срба, прир. Бојан Јовановић, Научна књига, Београд, 1992. 
врлине и способности српског народа више пута су посведочене током дуге и богате историје српског народа и других народа који су живели на овим просторима и делили заједничку судбину.

Издвајамо две веома важне карактеристике које се везују за јунаке са ових простора, али које нису стране ни другим народима. Дубоко су повезане са духовном димензијом културе, и то њеним етичким аспектом, а то су чојство и јунаштво, као највиши морални степен који један јунак или војник може достићи. Чојство као посебна категорија оплемењивања јунака у човеку јунаштва у чојство. У генеалогији јуначког морала долази прво јунаштво, а као његова круна чојство. Јунаштво је његова неопходна претходница, без које ни морално најсавршенијем човеку не може припасти карактеристика чојства ${ }^{198}$ humanitas.

Од војника-ратника се прво очекивало да најпре испуни племенску и националну дужност: буде домаћин, ратник, ослонац своје куће, свога братства, свога племена, свога народа; затим да испуни законе јунаштва, а да тек онда себи дозволи да човека, ратника и јунака у себи савлада и да се уздигне ка чојству. Наиме, сматрало се да свеукупно јунаштво, јуначка слава, стечена у неуморном такмичењу са себи равним јунацима, нема вредности ако, поред јунаштва, није испољена и човечност. Ако човек у својој природи има и ратничке пориве, постићи ће врхунац свога чојства, ако своје ратничке нагоне

198 Чојство се често пореди са витештвом и са витешким понашањем. Витештво је несумњиво морално наслеђе феудализма европских крсташа и старе српске државе, те је, услед вечите борбе за хришћанску религију и хришћански морал, добило извесну религиозну примесу; оно ипак стоји ближе ономе што Црногорци зову јунаштвом него оно што хоће да се каже изразом чојство. У свим подстрецима који су се у Србији и у Европи означили и ценили као витешки, често се скривала тежња да се пред јавношћу што више импонује. При испољавању „херојске људсковине“ - чојства - често се његов носилац мора помирити с тим да га околина, потонула у старе обичаје и традиције, неће разумети, јер чојство често захтева и етичко савладавање обичаја. А то се за витештво не може рећи, јер се витешки гестови лако преливају у став и позу што тражи публику која ће се дивити. 
победи и савлада у нешто веће и боље - дакле, кад победи законе своје околине, своју природу. ${ }^{199}$

Поред војничких врлина, заснованих на етичким кодексима, веома је важно напоменути и економске и политичке врлине, које је изнедрило пуританско 200 грађанство XIX века, а које је одредило животни стил оних који привређују и управљају, те их својим надмоћним притиском обликовало. Макс Вебер је говорио како на Западу идеалне и трансцендентне покретачке енергије на специфичан начин прожимају професионално организована подручја деловања и представљају њихов ослонац. ${ }^{201}$

Садржај етичког кодекса у оквиру различитих професија условљен је и значајем професије и делатности за друштво, а самим тим и за безбедност. Придржавање принципијелних захтева и прописа, неговање моралних вредности, поштовање грађана и њихових права и слобода, поштовање

199 На сличан начин се могу представити идеали јапанских витезова - самураја и њихов самоникли етички систем - бушидо - као пут ратника и извориште врлина које се у Јапану посебно цене, као што су: честитост, учтивост, одважност, милосрдност, искреност, част, оданост и самоконтрола. О самурајима и њиховом ратничком кодексу и улози коју су одиграли у уобличавању моралности, етике и естетике Јапана, како у прошлости тако и садашњости, видети у књизи познатог јапанског предавача, борца за мир и међународног политичког активисте с краја XIX и почетка XX века, Иназо Нитобе, Бушидо - душа Јапана, објављеној и код нас 2006. године у оквиру издавачке куће Исполин у Београду. У том делу аутор открива одакле потиче изворни дух јамато и како ради вековима стари компас оличен у животима јапанских самураја и мудраца, упоређујући их са универзалним тековинама западне цивилизације, откривајући сличности и разлике између Јапана и Запада, између старог и новог. Оригинална електронска верзија књиге доступна је на: www.gutenberg.org/ebooks/12096.

200 Захваљујући аскетском принципу „самоконтроле“, пуританизам је отац и модерне војне дисциплине... Кромвелови „ironsides“, који са откоченим пиштољима у руци, али не пуцајући, оштрим кораком напредују ка непријатељу, супериорни су не због своје дервишке страсти, већ, напротив, због своје трезвене самоконтроле, захваљујући којој вођа може њима да управља у сваком тренутку; супротно томе, свако витешко обрушавање „сavaliers“ завршава тако што се распадну на атоме. Видети: Фолкер Хајнц, Увод у Макса Вебера, Библиотека XX век, Београд, 2011, стр. 42.

${ }^{201}$ Исто, стр. 39. 
институција показатељи су изграђеног професионалног кодекса привредника, политичара, припадника безбедносних структура, који таквим својим понашањем, свако у свом домену рада, доприноси квалитету безбедности и сигурности на свим нивоима рада и постојања једног друштва и државе. Такође, доприноси јачању поверења код грађана у њихов рад и професионални однос према свему што их окружује.

Наравно, овде се не исцрпљује обим и садржај духовне димензије културе, јер га можемо пронаћи и у стваралачкој сфери, која иновативним потенцијалом и могућностима ствара услове да се нешто предузме, произведе, оствари, уједно и производи, креира нешто ново, све са циљем задовољења друштвених потреба и побољшања квалитета живота.

Како смо већ и назначили, материјална и духовна димензија културе не постоје независно једна од друге. Духовна култура је дата човеку у материјализованој форми и захтева дешифровање уз помоћ одређеног система значења. Материјална култура се пак укључује у праксу посредством духовне културе. Непрекидни прелазак идеалног у активност, затим у материјалну форму, па обратно, има тај смисао што се само у њему долази до синтезе резултата индивидуалних напора, до усвајања синтетичких културних продуката од стране појединачних личности и до нове рекомбинације културних елемената у још сложеније и богатије комплексе. Све то има посебну тежину и оправданост у сфери безбедности, где једно не искључује друго, а узајамним подстицајем на развој и напредак доприносе квалитету живота, сигурној егзистенцији и безбедности грађана и целокупног друштва.

\subsection{6 Културни обрасци и модели понашања у сфери безбедности}

Као што је већ наведено у делу о културним обрасцима, можемо их третирати и као начин живота и као оквир у којем се интегрише једна заједница, са сопственим изграђеним вредносним системима, који помажу појединцима и друштвеним групама да разумеју себе и свет који их окружује и да им пружи 
моделе по којима ће они реализовати изабране циљеве и промовисати пожељан начин живота.

Такође смо истакли да описати и на неки начин оценити културу једног народа захтева узимање у обзир свих грана његовог духовног живота, дакле његову науку, веру, морал, његову књижевност и уметност, али исто тако и његову политику и право, његову војску и привреду, његове обичаје и забаве. Анализом области безбедности може се доћи до сазнања каквим се културним обрасцима руководе одређени народи или нације, када је у питању начин вођења ратова, третирања опасности, извођења самог чина борбе, приступа одређеним безбедносним појавама и проблемима, изградња структурних елемената у подручју безбедности и друго.

Ако у дискурс о културним обрасцима уведемо и историјски, политички, економски и религијски момент, онда можемо навести следеће: племенски ратови се разликују од националних, а ратови између држава често добијају облик зависан од уређења; другачије ратове воде краљеви као вође или власници држава, другачије демократске националне државе, а другачије тоталитарне државе; ратови у име религије најчешће су другачији него у име династије, мада је понекад тешко уочити разлику; религијски ратови између католика и протестаната у Француској у XVI веку разликовали су се од крсташких ратова или од џихада.

Лако се може сагледати и разлика у томе који смисао има појам рата с обзиром на организационо-техничку посебност. Рат у епохи мача и лука изгледао је другачије него у време ватреног оружја, оклопно-механизованог оружја, авиона или ласерског оружја. Међутим, рат је увек покушај да се силом постигне корист која се не може остварити политиком. Имајмо при свему овоме у виду и улогу силе - и онда када не долази до отвореног сукоба - улогу уцене и значење културе. Рат није увек резултат логичке калкулације снага, а његов резултат не зависи увек од ангажоване снаге и средстава. Техничка и културна димензија не скрива битну аналогију која омогућава да се рат разликује од сваке друге употребе силе у односима између људи. 
Разлози из којих се воде ратови могу бити тежња за владавином, за пленом, експлоатацијом, а разлике се јављају у облицима деловања. ${ }^{202}$ Такође се и ратови схваћени као војне конфронтације, који треба да доведу до владавине или до стицања других користи, веома разликују с обзиром на примењене концепције вођења борбе. У многим цивилизацијама постоји обичај регуларне борбе која није подређена само принципима него и својеврсној арбитражи. То уопште не значи олакшање конфликта. Ритерски кодекси се јављају у различитим цивилизацијама (андалузијска, јапанска, латинска), али је различита њихова форма, јер се правила позивају на друге вредности и на различите традиције - једном речју, различите културне обрасце.

Једна од димензија културе којима се бавио Хотстеде јесте избегавање несигурности и можемо је такође сместити у одређену матрицу-образац, кроз коју се преламају особине култура различитих народа и на основу тога се могу поредити. ${ }^{203}$ Избегавање неизвесности представља степен до којег се људи осећају угроженима у различитим ситуацијама, па су развили веровања и институције које покушавају да избегну такво стање. Земље где живе људи који не воле несигурност, према Хофстедеу, склоније су већим потребама за сигурношћу и снажном веровању у експерте и њихово знање (примери Немачке, Јапана, Шпаније, САД).

Тамо где је мање избегавање несигурности живе људи који су спремнији да прихвате чињеницу да ризик увек постоји, јер се никада не зна шта ће се догодити, а живот мора да тече даље, без обзира на то. Примери таквих земаља су: Француска, Данска и Велика Британија. Утицај ове димензије може се сагледати на више начина. Тако, на пример, земље код којих се несигурност више избегава пажњу поклањају структурирању организационих активности,

202 У индијској цивилизацији доминира модел вазалне владавине, односно потчињавања побеђеног владара, при чему му се оставља власт над његовим дотадашњим поданицима. Исти принцип је примењиван и у Кини, Јапану и Европи у одређеним историјским тренуцима. Вазални односи у европском средњовековљу ипак се разликују од индијске верзије империје, изграђене на хијерархији подређених владара.

203 Geert Hofstede, Culture's Consequences: International Differences in Work-Related Values, Beverly Hills: Sage Publications, 1980. 
имају више писаних правила, више менаџера који избегавају ризичне ситуације, нижи радни промет и неамбициозне службенике. Друштва код којих се несигурност мање избегава имају слабије структуриране организационе активности, мање писаних правила, више менаџера који се хватају укоштац са ризиком, већи радни учинак и амбициозније кадрове. Организација охрабрује запослене да буду самоиницијативни и да предузму одговорност за своје поступке. $^{204}$

На сличан начин се може објаснити какав однос и какав образац имају поједина друштва према питању поверљивости, које је у сфери безбедности веома осетљиво и захтева специфично понашање. Када се каже да је нешто „корпоративно поверљиво“, у западној култури се разуме да нешто мора бити чувана тајна у оквиру компаније и то се одређује преко регулативног нормативног акта. У Азији (пацифички регион) тајност је потпуно непознат концепт, јер је став према безбедности информација утврђен дуготрајним социо-културним обрасцем који подразумева апсолутно поштовање приватности.

Трагови и последице културног наслеђа који су се задржали и део су културних образаца савремених друштава често се одупиру променама и представљају препреку друштвеном развоју. Прихватљиви облици понашања и начин на који се третирају одређени проблеми у друштву веома се разликују од једне до друге културе и често могу бити екстремно другачији. Како се испољавају одређена емоционална стања (страх, љубав, бес), како се вреднују категорије као што су породични живот, комуникација, однос мушкарца и жене, ауторитет и колико се одређени проблеми уводе у јавни дискурс (насиље у породици, инцест, педофилија и слични) разнолико се манифестује у различитим културама и њиховим културним обрасцима.

Још један пример који можемо додати овој дискусији представља и начин на који се можемо одбранити од опасности, а значајно је повезан са модернизацијом, али и новом улогом простора, где опасност настаје или се

204 Љубомир Стајић, Саша Мијалковић, Светлана Станаревић, Безбедносна култура, Драганић, Београд, 2005, стр. 84. 
производи. Заштита од опасности била је основни мотив за изградњу градова, чије су границе обично биле дефинисане високим зидинама или оградама, од древних села у Месопотамији, преко средњовековних градова до насеља америчких Индијанаца. Зидови су обележавали границу између „нас“ и „њих“, реда и дивљине, мира и рата. Непријатељи су остављени са друге стране ограде и није им се дозвољавало да је пређу.

Међутим, у двадесетом веку долази до промене и градови се више повезују са опасношћу него са безбедношћу - односно, од склоништа против опасности претварају се у главне изворе опасности. Они који то могу да приуште - праве заштитне ограде против свих видљивих и невидљивих, садашњих и предвиђених, познатих или још увек непознатих и свеприсутних опасности, закључавају се иза зидова, покривају ТВ камерама прилазе својим домовима, ангажују наоружано обезбеђење, возе оклопљена возила, носе заштитне прслуке или узимају часове борилачких вештина. Овакве и сличне активности реафирмишу и поспешују осећај хаоса. ${ }^{205}$

Све то, наравно, утиче на грађане и њихову перцепцију живота у граду, на наду и страхове које обично везујемо за урбано окружење, али и револуционарно мењање услова урбаног живота или заправо услова̂ живота човечанства. Промена услова̂ живота неизбежно производи и промену начина живота.

\section{3 Култура и безбедност - нивои рефлексије}

На преласку два миленијума безбедност је постала централна тема економског, друштвеног и политичког живота сваке земље, која улази дубоко и у сферу уметности и културе. Такође, култура заузима важно место у студијама међународних односа, а све више и студија безбедности. Култура и безбедност заједно подстичу развој размишљања да се одговори на претње и рањивости

\footnotetext{
205 Свака додатна брава на улазним вратима као реакција на најезду криминалаца, свака промена начина живота и исхране чине свет још више непоузданим и пуним опасности и подстиче још више одбрамбених акција - које ће опет довести до истог резултата.
} 
којима је изложен појединац, друштвена група или друштво у целини, па и сама држава.

Економија страха, која је све израженија у савременом друштву, изазива и одређену реакцију културе и безбедности два посебна концепта који постају једно и на основу чега, уметници (на пример), уз професионалце у сфери безбедности, анализирају проблеме перцепције и заступљености страха у технолошки убрзаном друштву ризика. Конвергенција безбедносне индустрије и културе засноване на преклапању психолошких и емоционалних мотива постају очигледне и не изненађује да су баш уметници и културни радници први који су ово схватили и применили у пракси.

Постоји већ велика потреба улагања у развијање новог односа културе и безбедности. Субјективни доживљај нестабилности и личне несигурности широко обликује друштво у свом односу према ауторитарним импликацијама психолошких стања регресије и зависности. Уметници и културни радници могу донети разноврсност неким априорним монолитним концептима безбедности, и обратно, опстанак и друга савремена питања безбедности постају изазов за префињену уметност и културу.

\subsection{1 Релације појмова култура и безбедност кроз призму личности}

Култура представља основни вредносни оквир који усмерава понашање појединца. Огледа се у начину на који појединци перципирају уочене догађаје, личне интеракције, као и одабирању одговарајућих понашања у конкретним животним ситуацијама. Култура своје деловање манифестује у контексту социјалних институција, породице, образовања, религије, власти и пословних институција, те културни оквир обухвата објективну реалност, која се рефлектује кроз друштвене институције и вредности. Међутим, пошто култура укључује како свесне тако и несвесне вредности, идеале, ставове и симболе који обликују људско понашање, она укључује и субјективну реалност 
рефлектовану у личним, али социјално предиспонираним веровањима и понашањима.

Нивоима корелације човека са културом, који су различити по свом садржају, по дубини и по индивидуалном значењу, треба да одговарају и одређени нивои индивидуалне свести. Међу овим нивоима нема оштрих граница, јер личност представља психолошку непрекидност бивствовања и социо-културну целовитост. Ипак, потребно је да се нагласи извесна аутономност, јер се сваки од нивоа одражава у одређеним културним појавама. Говорећи о интегративним нивоима личности, Соколов се ограничио на издвајање три основна нивоа или слоја личности: ниво социјално-културних улога, ниво социјалног карактера и ниво егзистенцијалних структура. Сваки од ових структурних нивоа једне личности појављује се субјективно, у виду емоционалних стања, намера, мисаоне делатности, фантазије, а објективно - у поступцима, у производима рада и културним формама. 206

Безбедност се може представити као израз филозофије живота, дакле одређеног погледа на живот, појединачних и колективних страхова и тежњи, до очекивања о томе шта да жртвује, а шта је вредно да се сачува. Безбедност је такође одраз онога што је појединац спреман да жртвује и онога за шта је спреман да се бори или умре. Таквим одређењем безбедности стављамо је у оквир друштвеног, културног и, коначно, етичког концепта. У сваком случају, имплицитно је повезана са појединцем и људским вредностима.

У савременом свету безбедност је често повезана са материјално значајним аспектима живота, јер они имају тенденцију за укључивањем, ако не и заменом људских вредности. Али, вредности као што су техничке и материјалне не би требало мешати са самим животом. Безбедност не подразумева само ствари, она укључује људе који цене ствари и који имају потребу за одређеним стварима као средством за опстанак. Темељне и ефикасне мере безбедности стога морају да узму у обзир друштвене и културне силе које обликују појединачно разумевање шта безбедност (и небезбедност) значи, оно што

${ }^{206}$ Е. В. Соколов, Култура и личност, Просвета, Београд, 1976, стр. 193-227. 
угрожава вредности, које вредности највише, а када је у питању појединац, шта би требало да садржи његов одговор на кризу или катастрофу.

И као што се Клифорд Герц сложио са већином других теоретичара културе да је „човек непотпуна или недовршена животиња која се употпуњује односно довршава кроз културу“, тако и ми можемо додати да та „недовршена животиња“ има јединствену прилику и могућност (коју ниједна животиња не поседује), да свој опстанак учини извеснијим, управо захваљујући култури која ће за то дати средство или оружје.

\subsection{2 Пројекције на друштво}

„Друштво је свесно грађена заједница, планирана, рационална, организована, механичка и вештачка творевина, која се држи на разуму, себичности, калкулисању, прописима, спољним санкцијама, профиту.“ Немачки социолог Фердинанд Тенијес [Ferdinand Toennies] тако је објаснио појам друштва на основу кључне идеје у социологији о сучељавању два типа социо-културних односа „заједнице“ и „друштва“. 207

Из мноштва дефиниција друштва могу се извући заједничке карактеристике, као што су специфичан начин удруживања, а не прост агрегат индивидуа, заснивање на положају људи према месту које заузимају у друштвеној подели рада, уређивање међусобних односа и деловања на основу утврђених положаја индивидуа у друштвеној организацији. Као посебан елемент друштва Талкот Парсонс наводи особену институционализовану културу као носиоца формиране колективности, тј. да друштво као организовани систем представља „јединствен систем институционализованих вредности“, односно постојање заједничке културе, која повезује његове чланове.

Отуда се може рећи да појам друштва и друштвене структуре нужно укључује како колективна понашања тако и обрасце, значења, симболе, идеје, вредности.

${ }^{207}$ Ferdinand Toennies; наведено према: Загорка Голубовић, Антропологија, Службени гласник, Београд, 2007, стр. 79. 
Друштвене структуре су творевина културе, али оне и производе културу. У сваком случају, више су него институције и више него организације.

Често се наводи разлика између људског друштва од животињских „друштава“ и сматра се да оно није прост агрегат индивидуа, већ је другачија реалност од простог збира појединачних чланова. Људско друштво се разликује од животињских заједница, пре свега, по томе што људи удруживањем постижу одређене циљеве, које они што се удружују свесно формулишу и у зависности од њих бирају тип организације и средства за њихову реализацију. ${ }^{208}$

У социологији се под снажним утицајем Диркема и данас истиче као основна карактеристика друштва: оно што је објективизовано, институционализовано, спољашње и што стоји изнад индивидуа, делујући на њих као сила притиска. Овде је занимљиво поменути да антрополози и етнолози употребљавају термин „култура“ скоро у истом значењу у којем социолози користе термин „друштво“. Управо је питање међусобног односа друштва и културе често доводило до посебних дискусија, а терминолошке разлике (често) и до теоријских разилажења. ${ }^{209}$

Свакако можемо рећи да се друштво (као и култура, уосталом), јавља као сложен систем организованих форми живота већ у својим најранијим облицима. Бројни елементи који чине срж друштвене структуре могу се пронаћи у сваком друштвеном систему; разлике настају у погледу принципа који се примењују, у распореду који поједини елементи добијају у друштвеној структури, у облицима у којима се организација оформљује итд.

Друштво се може приказати и као арена сукоба различитог карактера и ти сукоби су присутни током читаве историје људског друштва. То је, дакле,

\footnotetext{
208 Људи свесно одређују циљеве и врше избор, организују социјалну акцију ради остваривања изабраних циљева и дефинишу много шири репертоар циљева него што су то они циљеви који су повезани са одржањем биолошке егзистенције. Јасно је да људско друштво није само нова форма у континуитету биолошке еволуције, тј. виши облик у борби за опстанак, већ је својеврсна организација, којом се остварује нов начин егзистенције.

${ }^{209}$ У литератури је већ одавно познато да су оно што су Тејлор, Боас и Малиновски звали културом Кант, Спенсер, Вебер и Диркем означавали као друштво.
} 
константа историјских збивања и најчешће се приказује као последица различитих система вредности који постоје упоредо и често су у колизији. Јасно је да те разлике имају и дубље основе - у крајњем случају, у различитим интересима људи. Друштвене институције и друштвени поредак граде се на основу различите идентификације феномена добра и зла, односно онога што је позитивно и вредно и онога што представља опасност и може да угрози.

Друштвени односи, уз друштвено деловање, представљају основу друштвеног живота људи и производ су разноврсних контаката и веза у које људи ступају ради обављања заједничке делатности и одржавања индивидуалног и друштвеног живота. Ниједан друштвени однос није могућ без међусобног схватања смисла и значења радњи и поступака који граде тај однос у којем се положај једних према другима одређује и на основу понашања које испољавају у неким (безбедносним) ситуацијама. Као веома значајни показатељи квалитета и карактера друштвених односа који на позитиван начин доприносе безбедности могу се узети солидарност, поверење, толеранција, међусобно уважавање и слично.

\subsection{3 Пројекције на заједницу}

Пројекција културе и безбедности на заједницу има специфичну тежину, с обзиром на то да се заједница може представити као интимна, природна, спонтана друштвена скупина, настала стихијски, сама од себе, дугим развојем. Учвршћивала се осећањима, обичајима, љубављу, традицијом, солидарношћу, присношћу и поверењем. Заједнице као скупине људи са заједничким осећањем припадности (породичне, језичке, етничке заједнице итд), онако како их види Андерсон, готово увек су „замишљене“. ${ }^{210}$ Наиме, редак је случај да се сви чланови неке заједнице - сем када је њена величина врло ограничена -

\footnotetext{
210 У студији Бенедикта Андерсона (1996), израз „замишљене заједнице“ промовише се када Андерсон говори о појави националних заједница да бисмо боље разумели значење повећане човекове способности да помоћу имагинације сагледа себе као део ширег простора који дели са другим људима.
} 
међусобно познају, а још ређе могу да се лично увере у „истовременост тока“ својих свесних доживљаја.

$\mathrm{C}$ обзиром на то да се узима у разматрање и имагинација, дилема је да ли је прикладно ограничити се на анализу везану за одређену територију. Наиме, не може се задовољити само анализом друштвених активности, културних феномена и институција које сачињавају културу неке локалне скупине људи. Пажња се обраћа и на идеје које све више настају услед постојања замишљених заједница и губљења територијалног обележја, због миграција, протока добара и средстава за информисање. ${ }^{211}$

Френсис Фукујама у Судару култура наводи да се заједнице заснивају на узајамном поверењу ${ }^{212}$ и не могу настати спонтано, уколико не постоји поверење. При том је нужна и хијерархија, зато што сви људи једне заједнице не живе у њој равнајући се само према прећутно прихваћеним етичким правилима као заједничким. Увек постоји мањи део који може бити активно несоцијабилан и склон да гледа да поткопа, односно искористи групу служећи се притворношћу и прикривањем злих намера. „Хијерархије су нужне зато што се не може веровати свим људима да ће у свако доба живети у складу са интериоризованим моралним правилима, тј. да ће у подједнакој мери делити ова правила.“213

Пошто заједница зависи од поверења и пошто је поверење заузврат, условљено културом, следи да се спонтане заједнице могу појавити у разноликој мери у различитим културама. У заједницама са високим нивоом међуљудског

211 Тако су сада актуелне виртуалне заједнице, које се стварају на интернету и друштвеним мрежама, где деловање тих заједница уопште не подразумева физички контакт, нити лично познанство.

212 Поверење је очекивање једних чланова заједнице да ће се други чланови те заједнице понашати регуларно, поштено и кооперативно, захваљујући томе што заједнички деле одговарајуће норме. Те норме се могу тицати дубоко вредносних питања, као што је природа Бога или правде, али оне такође могу обухватити и професионалне стандарде и кодове понашања.

213 Френсис Фукујама, Судар култура, Завод за уџбенике и наставна средства, Београд, 1997, стр. 34-35. 
поверења, попут Јапана, створене су информационе мреже много пре но што је информациона револуција добила велики замах. С друге стране, друштва и заједнице са ниским степеном међуљудског поверења вероватно никад неће бити у стању да искористе предности које на плану ефикасности нуди информациона технологија. То није једина сфера у којој се истичу предности изграђеног поверења.

У области безбедности поверење је такође кључни фактор, јер су у „игри“ нечији интереси који могу имати различит карактер (национални, на пример), нечије вредности, као што је и највећа - људски живот - и томе слично. Значај поверења превазилази границе сложености у друштву или заједници и игра значајну улогу у свим односима који се граде унутар заједнице или са спољашњим окружењем. У стварном свету нису сви појединци поуздани, па човек мора научити да препозна људе са којима никада неће бити у стању да оствари односе поштовања и поверења. Али када су такве везе могуће, човек мора да се потруди да их створи и одржи.

Као што је Кант показао у свом делу Основи метафизике морала из 1785. године, када не постоји поверење, пропушта се корист од сарадње, али се такође губи мање опипљиво, али не мање важно: поштовање једних за друге. Када све подигнемо на виши ниво, недостатак поверења неће омогућити зближавање заједница и успостављање сарадње пред заједничком опасношћу и претњом која их подједнако може угрозити, али исто тако неће створити услове за узајамно поштовање и уважавање.

Поред поверења, важно је нагласити и следеће карактеристике заједнице: да би индивидуе у својој заједници учествовале као индивидуе, оне морају у њој бити повезане као индивидуе, суштинским везама, преко заједничких интереса и потреба, а не само институционално - преко додељених улога и статуса; оне морају имати свест о заједничким циљевима; морају комуницирати на бази реципрочних очекивања-испуњавања; та заједница мора бити тако формирана да омогући непосредан однос између чланова и контролу од стране индивидуа над пословима друштва; она мора бити заједница у правом смислу, заснована на узајамним правима и обавезама, као и одговорностима, а не вештачка 
творевина са наметнутим ауторитетом. Наравно, тешко је усагласити све критеријуме и добити „идеалну људску заједницу“, посебно ако претпоставимо да је за њено функционисање неопходно узети у обзир како захтеве друштва тако и захтеве људске природе, који нису идентични и не могу се сводити једни на друге.

Ако функционише заједница, слобода и безбедност (мир) могу да постоје као добро. Заједница тада преузима одговорност за свој сопствени живот, јер људи постају слободни да довољно деле и довољно обезбеде да се сложе и споразумеју на најбољи могући начин. Осећај повезаности и формирање друштвених мрежа чини оно што је постало познато као друштвени капитал и што је сигурно важно и за опстанак и напредак заједнице. Природа одржава живот стварајући и негујући заједнице. Ако заједница не постоји, осећа се њено недостајање. Заједница је заправо центар за дефиницију одрживости. Индивидуа сама по себи не може бити одржива, а стварањем заједнице стварају се услови одрживости.

Потреба да се државе функционално повежу - у циљу успостављања пријатељских односа и узајамне безбедности - условила је у другој половини двадесетог века стварање нових установа међународне безбедности, а једна од њих је безбедносна заједница. ${ }^{214}$ Модел безбедносне заједнице се супротставља традиционалном понашању међународних актера (познато као безбедносна дилема) и наглашава се потреба контролисања и ограничавања силе, као и унапређење разумевања, као услова отклањања сукоба. ${ }^{215}$ Дакле, компромиси,

214 Појам потиче од теоретичара Карла Дојча (1957), који га је произвео анализирајући међународне односе у северноатлантском региону. Према њему, могу се разликовати плуралистичке и амалгамиране заједнице, с обзиром на степен (не)зависности који државе задржавају у заједници. Безбедносна заједница, посматрана као група држава, подразумева висок степен интеграције, који се огледа у изграђеним заједничким институцијама, праксама и осећањима заједничког идентитета, великом међусобном поверењу и заједничкој идеји да се сви проблеми решавају мирним путем. Видети: Филип Ејдус, Међународна безбедност: теорије, сектори и нивои, Службени гласник и Београдски центар sa безбедносну политику, Београд, 2012, стр. 85-86.

215 Драган Симић, Наука о безбедности, Службени лист СРЈ и ФПН, Београд, 2002, стр. 51. 
уважавање туђих интереса, поштовање закона и избегавање сукоба представљају вредности које подстичу демократију и поштују се унутар заједнице. Јединственост заједнице се огледа у томе што су сви њени чланови демократске земље које поштују и подржавају исте или сличне вредности.

\subsection{4 Пројекције на ентитет}

У најопштијем смислу ентитет означава биће. У разним контекстима реч се користи да идентификује јединицу, без обзира на то да ли су у питању конкретне ствари или апстрактне идеје које немају спремно име или етикету. Може се представити и као особа, партнерство, организација или посао чије је постојање правно ${ }^{216}$ и посебно препознатљиво. За ентитет, дакле, има више објашњења, која могу бити политичког, ${ }^{217}$ дипломатског, војног, правног, друштвеног и филозофског карактера.

Уколико као референтни оквир ентитета посматрамо људска бића, потребно је преко егзистенцијалне анализе показати како она исказују интерес за безбедношћу посредством категорија очувања, извесности и сигурности. Да би се остварио интерес безбедности, морају постојати критеријуми, као неопходни услови за могућност остварења, а то су идентитет, интегритет и суверенитет. На сличан начин се разматра пројекција ових категорија и критеријума на вишу форму ентитета, као што су држава или нација.

\footnotetext{
${ }^{216}$ У правном смислу ентитет је правно лице које је у стању да носи права и обавезе, утврђене правном нормом, као што је физичко лице или правно лице (привредни субјект или корпоративни ентитет).

217 Пример коришћења термина entity, који је америчка администрација употребила у Дејтонском споразуму, уз претходно деловање и учешће представника војно-политичког савеза НАТО (бомбардовање Републике Српске 1995. године), по свом карактеру је политичке и војне природе. У политичком језику америчке дипломатије означава самоодређено државотворно тело и карактер државности предметног бића, национални идентитет, затим народну, културну, историјску, језичку и религијску посебност, право на самоодређење итд.
} 
Без обзира на то са којег становишта посматрамо ентитет, у сваком његовом облику се преламају елементи културе и безбедности. Култура као нешто што обликује, дефинише вредности, норме, стандарде (неке организације или другог правног ентитета) и начин на који ће обликовати интерес за безбедношћу, која је неопходан услов да такав један ентитет нормално функционише и развија се. Готово истоветно сучељавање и преламање културе и безбедности проналазимо и у ентитетима који представљају само апстрактну идеју или филозофску замисао.

\section{4 Култура као национални безбедносни интерес}

Као што смо приметили у досадашњем излагању, у људском животу култура фигурише као вишезначна појава, а да бисмо је успешно разумели и објаснили, мора се водити рачуна и о њеном деловању, односно функцијама које врши. Култура проширује могућности човека у правцима које му је предодредила природа, а истовремено га развија и усавршава. Издвајање основних функција културе, којима одговарају основни системи културне активности друштвеног човека, не подударају се са издвајањем конкретних елемената културе, културних комплекса и институција. ${ }^{218}$ Без обзира на то како су се мењала значења и функције појединих културних појава, ма каква прерасподела функција да се вршила између различитих културних институција, извесне основне функције културе ипак су се очувале у току читавог периода људске историје који нам је познат.

У делу који следи указаћемо на функције културе које производе нарочите импликације за безбедност. Свака функција културе одговара и једном систему делатности, а може се окарактерисати са више различитих аспеката. Један

\footnotetext{
${ }^{218}$ Било који културни елемент може имати различите културне функције, које су ипак са своје стране изложене променама. На пример, ритуал може да врши комуникациону функцију, да буде форма емоционалног пражњења или „одвођења“ агресивности из човековог понашања. Према: Е. В. Соколов, Култура и личност, Просвета, Београд, 1976.
} 
аспект могу бити људске потребе и интереси, али и то како они условљавају одређену функцију. Затим, можемо говорити о настанку те функције, развоју и историјским перспективама, о њеној улози у животу друштва, положају у односу на друге функције, о конкретним формама и институцијама помоћу којих се она ефикасније остварује, као и о културним вредностима које се стварају у оквирима дате функције. И како наглашава Е. В. Соколов, „рашчлањавање културе на квалитативно различите функционалне системе делатности одговара, с једне стране, унутрашњим императивима људске активности, а с друге - захтевима очувања и развоја културе“. Такође, можемо рећи да функција често описује културу као интегрисан феномен где је једна особина културе индиректно укључена у преживљавање, док је нека друга директно.

Култура као својеврсни феномен сигурно се не исцрпљује у својим функцијама, али објаснићемо и протумачити неке од њих, за које сматрамо да су од посебног значаја за представљање културе као националног безбедносног интереса.

\subsection{1 Функција опстанка}

Сви концепти безбедности садрже једну најопштију вредност и интерес, који омогућавају да се преживи, да се сачува идентитет и да се даље развијају појединац, група, колектив, заједница. То је уједно и услов да се достигну и развију остале вредности у којима ће се потом и уживати. На који ће се начин издвојити поједине вредности и како ће се дефинисати улога и место које им припада, одредиће култура.

Човек је првобитно, живећи у свом природном окружењу, био заокупљен питањем како да преживи и обезбеди свој физички опстанак. А онда, развијајући своју друштвеност у свим сферама живота усмерио се ка стварању услова̂ за свестран и слободан развој, у оквиру којег ће стећи способност да оствари, очува и унапреди сопствену безбедност и безбедност људске 
заједнице. Када достигне задовољавајући степен безбедности, човек је испунио услов да оствари слободу и несметан развој.

Култура се може сагледати као свеукупност одговора (који могу бити и успешни и неуспешни) што их је човечанство дало на основне људске потребе уопште, а нарочито на потребе појединих људских група, појединаца и заједница који се узајамно условљавају на различите начине. Већ на основу самог тумачења појма културе у првом поглављу, уочили смо да он упућује на потребу да се култура схвати као средство човека за опстанак. Заправо, то је била њена првобитна улога и тај принцип живота који се огледа у човековој борби за опстанак био је одлика најранијег периода развоја људске врсте. Оног тренутка када је почела да се развија уметност, као нова димензија културе, развијале су се и нове функције, које су потиснуле функцију опстанка.

Свет, који је већ добро загазио у трећи миленијум, као да се поново враћа на почетак своје историје, јер је питање опстанка поново актуелизовано, нарочито након пораста глобалних претњи чије деловање доводи у питање опстанак људске врсте. Култура је та која мора поново мотивисати људе да преживе. Она мора да људима обезбеди смисао живота на неком нивоу који ће им бити подршка и за опстанак. Без ове основне мотивације људи не би обављали свој посао како треба, а самим тим не би могли да наставе своје постојање, док би сама култура изумрла.

У теорији функционализма постоје одређена размимоилажења о томе чије потребе култура треба да задовољи, па тако издвајамо представника структурног функционализма Редклифа Брауна [Radcliffe Brown], који тврди како све културе служе да подрже социјалну структуру групе, где прво морају бити испуњене потребе групе, пре потреба појединца. Бронислав Малиновски је више развијао психолошки функционализам, наводећи да сва понашања првенствено подржавају потребе појединца. Свака подршка друштвеној структури расте само у случају да су одређена понашања повољна за појединца. ${ }^{219}$

\footnotetext{
219 Загорка Голубовић, Антропологија, Службени гласник, Београд, 2007.
} 
У сваком случају, потребу за опстанком култура може задовољити различитим одговорима, па тако и када су у питању индивидуа (ти одговори се односе на храну, алат, безбедност, односе са другим људима, медицинске потребе, страх и/или стрес), друштво (репродукција која подразумева и социјализацију деце, производња и дистрибуција ресурса, одржавање реда) и институцијје (сродство, влада, закон, привреда, религија).

Ако се култура првобитно схватала као процес и резултат суочавања и сукобљавања човека са његовом околином, као такозваном „првом природом“, у сврху стварања нових, повољнијих околности за живот и опстанак оне „друге природе“ - природе коју је према својим потребама преобликовао човек, укључујући и промене на себи самом, у новим, измењеним околностима потребно је преосмислити читав процес културног стваралаштва и ставити га у функцију очувања живота на Земљи и очувања планете Земље у универзуму.

Функција културе заокупљена опстанком огледа се и у обезбеђивању смисла живота и смрти, или, како је рекао Макс Вебер, култура даје смисао и значај за наш живот у иначе бесмисленом универзуму.

\subsection{2 Функција комуникације}

Функција комуникације се везује за културу захваљујући чињеници да је свака људска јединка релативно изолована, а опет - сама себи недовољна. Она своје потребе мора да задовољава изван себе и помоћу других, па самим тим мора да развија широке везе комуникације. У свему томе култура значајно помаже.

Ова функција одговара човековој потреби да комуницира са другима. Она је условљена биолошко-психолошким и социо-културним условима, који захтевају континуирану размену информација, енергије и емоција. Циљ комуникације је да се успостави сарадња са себи сличнима или онима са којима се деле исте вредности и заступају заједнички интереси. 
У антрополошком смислу је она важна за продужавање врсте и одржавање генетске целовитости, ${ }^{220}$ у социјалном смислу неопходна је за функционисање социјалних институција и социјалног система, у психолошком смислу везана је за задовољавање личности и за живот мањих неформалних група, на крају, важан је и њен апстрактни смисао, који се огледа у јединству индивидуа у оквирима духовне културе, њиховој општој тежњи ка истини, добру и лепоти. Захваљујући комуникацији човек истински постаје члан друштва и развија у себи квалитете које поседује. Међутим, комуникација не доводи увек до слагања и узајамног разумевања.

Као основа за људску комуникацију служе знакови и знаковни системи, тј. симболи. Највиши и најсложенији инструмент културне комуникације јесте језик, који се састоји од система значења, а ови су фиксирани, па се преносе у виду звучних и писмених симбола. И управо је то ненадмашна способност човека (настала као плод еволуције нашег мозга) да ствара идеје и представе о свету, тј. да ствара симболичку димензију сопствене егзистенције. Природном језику се приближавају вештачки језици у науци, а исто тако и специјални језици за слепе, глувонеме, као и многобројни системи кодова и шифри, карактеристични најпре за област безбедности и заштите.

Да би се успоставила успешна комуникација, потребно је да систем симбола буде познат свим учесницима који ће га прихватити и помоћу којег ће исказати своје мисли и представе. Такође је неопходно да се учесници у процесу комуникације придржавају одређених правила, а управо њих обезбеђује култура. Процес активне људске интеракције не исцрпљује се само у оквирима објективних социјално-економских форми. Уколико је друштво сложеније, има виши културни ниво и уколико је развијенија личност, утолико већи значај добија општење на индивидуалном нивоу, које је условљено личном

${ }^{220}$ Човек мора стално да репродукује у новој форми интегралност свог генетског и друштвеног бића, која се непрекидно нарушава. Сфера и оруђе ове репродукције јесте култура - управо, они њени елементи и институције који врше комуникациону функцију. 
активношћу, условима и законима психолошког контакта и размене информација. ${ }^{221}$

Најразвијенији део човековог живота, захваљујући његовој интелигенцији представља управо комуникација - процес током којег долази до размене информација. Свака биолошка врста, да би се прилагодила средини, размењује информације као њен суштински чинилац и један од свеобухватнијих делова живота. Да би обезбедио храну, избегао опасност или пронашао партнера, сваки живи организам емитује прецизно одређене сигнале у правом тренутку и прима важне информације из природне средине. Уколико се комуникација не оствари, информације не размене (подразумева се да постоји узајамно разумевање поруке из информације која се прима), долази до губитка, повреде, или до смрти. 222

Специфичност комуникације је повезана са националном и културном традицијом. Тако, на пример, у тешким ситуацијама Американци ће дати предност преговорима „лицем у лице“, док Јапанци настоје да избегну ситуацију директног супарништва или конфронтирања, где би резултат у корист једне стране означавао „одузимање образа“ другој страни. У Јапану је иначе раширен обичај да се у спорним ситуацијама преговори воде преко посредника.

Да би се остварила духовна веза између генерација и наследило историјско искуство, неопходно је да се развију средства културне комуникације. Уколико је култура богатија, интензивније комуницирање међу појединим људима и

221 Култура ограничава сфере општења, регулише њихову дубину и интензитет помоћу сложеног система ставова, улога, статуса и смислова. Управо због свега тога, тешко да су остварљиве све замисливе могућности међуљудских интеракција. Видети: Е. В. Соколов, Култура и личност, Просвета, Београд, 1976.

222 Без делотворне комуникације између пилота и контролног торња авион не може да безбедно слети на писту, не може се спречити катастрофална последица цунамија уколико сеизмолошки центри не региструју таласе на време и не обавесте надлежне службе, зауставити терористичка претња или опасна трговина људима ако безбедносне структуре не реагују правовремено. У живом свету животиња ловац лако открива плен, и обратно, плен се захваљујући комуникацији лако ослобађа непријатеља. 
људским колективитетима, утолико је већа и потреба за ефикаснијим средствима комуникације. У другој половини XX века интензивно су се развила техничка средства масовне комуникације, као и брзи транспорт. Глобална комуникација је успела да стваралаштво, култура, информације, образовање постану апсолутно глобализовани и доступни свима. Такође, створила је могућност да се избегне принуда локалне средине, националности, локалне политике или религиозности. Таква комуникација производи и нове захтеве да се понуде нове дефиниције културе, ${ }^{223}$ културног идентитета, уметничког дела и сличних категорија.

На први поглед, развој технике је омогућио човеку да савлада време и простор, да умножи капацитете информационих канала и обезбеди тачно репродуковање мисли, живе речи, интонације и мимике. Међутим, та техника врло често не помаже при комуницирању, већ доводи до узајамног неразумевања. Промене у формама комуницирања и у техници комуникације морале би да буду праћене одговарајућим преиспитивањем самих циљева комуникације и порастом духовне хуманистичке културе, на чијим се основама могу и користити информацијске могућности, које су све напредније. ${ }^{224}$

Комуникација се може учинити ефикаснијом, уколико научно-технички прогрес укључи и савладавање духовне изолованости и узајамно разумевање.

223 Дигитална култура, као новији феномен, утиче на то да менталитет људи постаје све егзактнији и аналитичнији, способан да прихвати технолошки развој, иако с опасним заборавом афективних елемената. Дигитална култура је изнедрила тзв. нет-артисте, киберарт, творце дигиталних уметничких дела, дигиталне часописе, виртуелне библиотеке и књижаре, виртуелне креативне радионице и уметничке и интелектуалне заједнице с перманентном, инстантном комуникацијом, па чак и виртуелне школе и универзитете.

224 Препрека за дубље духовно комуницирање може бити и диференцијација знања и формирање језика сваке научне гране понаособ. И међу научницима блиских струка данас долази до међусобног неразумевања. Још је већи јаз између научника из природних и друштвених или хуманистичких дисциплина, као и између теоријских и примењених наука. Из тог разлога све је више тежњи да се унификује знање, да се изради јединствени научни језик и савлада раскорак између научно-техничке и хуманистичке супкултуре (Ч. П. Сноу). 
Усавршавање форми и начина комуникације мора да прати и спознаја њеног смисла и значења за све учеснике у том процесу.

\subsection{3 Нормативна функција}

Сваки појединац тежи томе да се у друштву понаша на апсолутно слободан, аутономан и понекад за заједницу чак штетан начин. Зато друштво настоји да помоћу културе или захваљујући култури као систему, изгради и одржи опште важеће норме, помоћу којих жели да утиче у правцу корисног и сврсисходног, а да спречи штетно и некорисно понашање. На тај начин норме које производи култура уперене су против стварања хаоса, нереда и дестабилизације једног друштва.

Функција норме се састоји у томе да искључи утицаје случајних, чисто субјективних мотива и фактора како би се обезбедила сигурност, прогноза, извесна стандардност и општа разумљивост понашања. Њена улога у друштвеном животу многострана је. Норме подржавају стабилност традиције, разних институција и личних узајамних односа, као и хомогеност друштвених група. Такође указују на најразумније, у пракси проверене начине активности, као и на начине решавања конфликата, доприносе консолидовању идеала и вредности, координирају и повезују различите видове културне активности, служе као симболи социјалне и културне припадности.

Какав ће бити садржај норме, зависи од циљева сфере делатности коју норма уређује. Различити видови делатности нису нормирани у подједнакој мери, а различити су и садржај и начин нормирања у појединим културама. ${ }^{225}$

225 У већини култура постоје доста строге норме које се односе на употребу алкохола и наркотика̂, постоје у мањем броју и оне културе које су толерантније према тим „пороцима“ и нормативно их третирају потпуно другачије. Све културе нормирају узајамне односе грађанских лица и друштвених институција, правила хигијене и елементарна правила заједничког живљења, услове узимања хране, породичне односе итсл. Традиција, али и климатски и неки други услови могу условити начин на који се нека делатност или друштвени однос нормира. Тако, на пример, конзумирање одређене врсте хране није условљено хранљивошћу намирница, већ традицијом и културом, које одређују врсту хране 
Без обзира на то да ли су норме друштвених организација и државе као посебне друштвене организације по својој природи обичајне, моралне или религијске, свима је заједничко да представљају заповест (императив) о понашању људи, те да су снабдевене друштвеним санкцијама и другим заједничким обележјима. „Не нормира се само материјална активност и понашање него и духовна активност.“ ${ }^{226}$ Усмени и писани говор регулишу се граматичким правилима, а мишљење законима логике. Соколов такође истиче да су памћење, уобразиља, представа и други психички процеси увек у мањој или већој мери нормирани, пошто се одвијају у конкретној друштвеној средини. Њихов садржај, усмереност и интензивност нису условљени само физиолошком активношћу психе и индивидуалним склоностима, него и моралним, ${ }^{227}$ религиозним и политичким нормама.

\subsection{4 Безбедносно-заштитна функција}

Култура ствара различита заштитна средства да би одржала неопходну равнотежу између човека и природне средине, да би га сачувала од опасности које су везане за сувишак или недостатак извесних животно важних фактора. У периоду након леденог доба и опадања температуре почело је коришћење ватре, топле одеће и грађење првих насеобина. С порастом културног потенцијала и људске активности, физичке границе друштвеног и индивидуалног живота, као и границе сазнајног света, постепено су се шириле. Свака нова сфера делатности човека коју је откривао проузроковала је и нове

и начин припремања. У неким културама се једу змије, пси, жабе или мачке, у некима другима је забрањено конзумирање свињског меса, говеђег меса и сличних намирница.

${ }^{226}$ Е. В. Соколов, Култура и личност, Просвета, Београд, 1976, стр. 150.

227 Моралне норме се од других видова норми не разликују по садржају, пошто не постоји нарочита морална активност која би се разликовала од рада, комуницирања и васпитања, него се разликују по томе што њихово испуњавање или неиспуњавање задире у битне интересе других људи или друштва у целини. 
опасности. На њих је култура пружала одговор стварањем ефикаснијих средстава заштите и заштитних механизама. ${ }^{228}$

Потребно је било време да човек превазиђе примитиван начин размишљања и уочи разлику између стварних (реалних) опасности и нереалних (свет магије и натприродних сила), како би на основу стварних изворишта опасности произвео и рационално одабрана заштитна средства. Њихова ефикасност је расла сразмерно човековом упознавању са његовим реалним и потенцијалним непријатељем. Средства културне заштите, без обзира на то да ли су материјална, социјална или психолошка, чине јединствен систем, где свако од њих има свој заштитни сектор, а опет, што је веома важно, повезана су са природним заштитним формама. При покушају да се постигне један вид заштите може доћи до слабљења других важних заштитних механизама. ${ }^{229}$

Улога заштитне функције културе постаје прворазредна управо данас, када су старе опасности (глад, болести, пожари и поплаве) добиле нове, страшније димензије, а у исто време настале су нове опасности, које је у многим случајевима произвело са́мо друштво. Затровани водени извори, затрован ваздух и ерозија тла, појава катастрофалних цунамија, али и међународни тероризам, организовани криминал, нове болести - прете да униште више форме живота на Земљи. Човечанство се суочава са питањем живота и смрти, па је самим тим принуђено да трага за комплексним и интензивним развојем друштвених заштитних средстава.

Организација одбране од природне опасности или катаклизме, од напада животиња или људског насиља укључује и одређене институције, као што су домаћинство или локална средина (муниципалитет). Заштита се врло често

\footnotetext{
228 Одлазак у космос био би немогућ без заштитних средстава од зрачења, од дејства ниских температура, недостатка кисеоника, као и од сувишне оптерећености приликом узлетања, или интензивне изложености високим притисцима и температурама приликом повратка на Земљу и проласка кроз њену орбиту.

${ }^{229}$ При уништавању једне врсте штеточина долази до нарушавања еколошког система, као и до страдања многих корисних врста, па се у систему средстава културне заштите појављују и нови проблеми и потреба да се одмах решавају.
} 
заснива на предвиђању и планирању. Начин грађења куће, подизање зидова, избор места за подизање насеља како би се избегла опасност плимског таласа, вулканске ерупције или земљотреса, или одбио напад потенцијалног непријатеља - сви ови видови предвидне или превентивне заштите могли би се повезати са биолошком потребом безбедности и њеним културно утемељеним одговорима заштите. ${ }^{230}$

Безбедносна функција културе „прати“ заштитну и помаже нам да направимо разлику између онога што је добро и онога што није добро за нас. Управо ова разлика доводи до сукоба на различитим нивоима, јер оно што је добро за нас не мора да буде добро и за друге, и обратно. Кроз безбедносну функцију култура нас учи да уочимо опасност, идентификујемо „непријатеља“, сачувамо изабране вредности, правилно усмереном и осмишљеном комуникацијом правимо компромисе и тражимо решења која ће бити мање „болна“, а која ће ипак обезбедити опстанак, пружити заштиту, одржати ред и дати смисао животу, па и смрти.

\subsection{5 Кумулативна функција културе}

Основу за културни континуитет сачињавају акумулирање и ускладиштење резултата̂ људског деловања (информације, знање, материјална достигнућа), који су се сакупљали током историјског развоја људске заједнице и који служе будућим поколењима. Преображај и савладавање природе, комуникација, постављање правила или норми представљају неопходан, али не и довољан услов да би се фиксирало - утемељило људско искуство и формирало „историјско сећање“. Потребно је уложити додатне напоре како би се резултати

\footnotetext{
${ }^{230}$ Још треба нагласити пре свега чињеницу да је организација заштите, било у виду отпора природним силама и животињама или људским бићима, увек институционализована. Другим речима, морали би проучавати материјалну средину - опрему рукотворина, систем правила, организацију људства и однос таквих организованих група према биолошкој потреби самоодржања и примењеним економским, легалним, васпитним и политичким техникама. Видети: Бронислав Малиновски, Научна теорија културе, „Вук Караџић“, Београд, 1970, стр. 136-137.
} 
сазнајне активности и размене информација, као и материјалних достигнућа, укључили у општи систем знања и били доступни будућим генерацијама. Наравно, то је могуће јер се култура кроз свој отворени карактер налази у непрекидном процесу уобличавања, где свака генерација нешто допринесе и остави печат сопственој култури.

Свеукупност психолошких, идеолошких, организационих и техничких услова који ће омогућити акумулирање знања и информација, њихово разврставање и оперативно проналажење захтевају и специјалне установе (библиотеке, информативне, стручне и научне часописе, институције за научни и истраживачки рад, информационе пунктове и слично). Неразвијене и неусавршене информационе службе и институције представљају „уско грло“ економског и научног деловања, што често може довести до апсурдних ситуација, где је проналажење постојећих информација компликованији и скупљи посао него што би било њихово поновно прикупљање.

Од примитивних друштава, где су се природно памћење, директно подражавање и усмени говор користили као основни механизми за културни континуитет, до данашњих дана много се напредовало у начину складиштења и чувања културног богатства. Прва већа револуција се повезује са писменошћу, када су знања и информације почели да се брзо акумулирају, систематизују, прочишћавају и мењају своју структуру. Како је друштвена стварност постајала сложенија и разгранатија и што се више нагомилавало знања, тако је и догматски начин њихове систематизације све чешће долазио у противречност са задацима разраде нових знања.

У складу са сазревањем појединих страна друштвених односа и специјализацијом видова друштвене делатности, формирао се нови, научнорационални метод распоређивања и синтезе утврђених чињеница и њиховог темељења у осмишљене, логичне, складне системе. Дакле, издвојиле су се специфичне области знања, специфичне вредности сваке од ових области, а исто тако и специфична правила синтезе знања унутар сваке од њих. Рационалним рашчлањавањем информација дат је подстрек развитку историјског, етичког, природнонаучног, практичко-политичког знања, 
безбедносног знања, као и осталих видова знања. Важан предуслов за разврставање знања и информација представљало је формирање привремене и историјске перспективе, одређене структуре времена у друштвеној свести, као и издвајање „историјске меморије“ од задатака практичног и политичког коришћења знања.

Сматра се да ће култура ефикасније опслуживати друштво уколико буде акумулирала већи обим информација, који правилно одражава њене сопствене особине и својства спољашњег света, и уколико буде слободнији приступ тим знањима и информацијама. Уколико култура не обрати пажњу на неки фрагмент стварности - на природне или друштвене односе - или ако није у могућности да изгради адекватан систем перцепције или организације извесног вида информација, онда ће она подлећи стихијским променама или непредвиђеним преображајима у животној средини. У класном друштву извесна ирационална веровања или „табу“ спречавали су да се види одређени сектор реалности који се одупирао развоју научних знања и рационалних норми понашања у одговарајућој области. Управо је карактеристика тоталитарних идеологија била да се разруши историјско сећање и да се прекине ток културне континуираности.

Памћење догађаја из сопствене историје представља способност једног друштва да одржи духовно здравље и специфичан начин живота. Здраво друштво познаје своју прошлост, црпе своју снагу из успомена на победе, на славне историјске тренутке, али не заборавља ни неправилне одлуке и грешке које су такође обележиле ту прошлост и историју и донеле много проблема и последица.

Знања, као систематизоване, организоване и усмерене информације, представљају акумулирану енергију умног рада. Она се из деценије у деценију, године у годину, из дана у дан повећавају невероватном брзином. Међутим, број проблема који се проучавају повећава се директно пропорционално обиму постојећих знања. Како нарастају проблеми, тако би требало да се умножавају истраживања и број научника, што је заправо немогуће. Јављају се ограничења 
научног рада, издвајају одређене смернице, праве избори, али се не зна унапред који ће избори и које смернице бити најперспективнији.

Стога на основу таквог редоследа ствари запажамо два друштва, две културе, које су у извесном тренутку своје историје начиниле различит избор, током времена су се удаљиле и почеле све више и више да се разликују једна од друге. Самим тим, расте број рањивих места културе и друштва, а смањује се њихова способност да одговоре на проблеме који се неочекивано појављују. Са једне стране, запажамо друштва која су извршила један избор и развила се у једном правцу који је донео много погодности и повољних услова за просперитет и развој, док, са друге стране, уочавамо друштва која су учинила другачији избор и усмериле развој друштва у правцу који је донео много тешкоћа, проблема и препрека, те самим тим успорио или уназадио то друштво. Кроз историју налазимо многе примере и за једну и другу врсту избора.

Све у нашој култури чини резултат знања и вештина које су полако нагомилане током времена. Без кумулативне карактеристике културе не бисмо имали дубоко научно знање, богате уметничке традиције или софистициране технологије. Ова карактеристика културе, такође, много помаже у изградњи капацитета једног друштва, једног народа да развија безбедносну културу која ће сходно том културном богатству и културном наслеђу уобличити она знања, ставове и понашања који ће дати одговарајуће усмерење и путоказ садашњим и генерацијама које долазе.

\section{5 Национална култура и национална безбедност}

Национална безбедност одређује укупне друштвене, државне, политичке, војне, еколошке и друге трендове и процесе, као и начин, квалитет и услове живота савременог човека. С друге стране, успостављање садржаја и функционисање националне безбедности утемељени су у друштвеним вредностима и нормама, и од њих су нераздвојни, па је и социолошко, политичко, културолошко 
(видети схему 8.) и свако друго рашчлањавање њихових односа незаобилазни елемент њиховог разумевања. Национална култура и национална безбедност налазе се у специфичном односу где национална култура својим акумулираним знањима, вредностима и веровањима, као и иновативним и креативним потенцијалом, омогућава да се нађе одговор на који начин и којим средствима да се изгради, развија и сачува национална безбедност и вредности које она штити.

\subsection{1 Различити приступи концепту националне безбедности}

Као што смо раније већ истакли, термин „национална безбедност“ датира из периода непосредно након завршетка Другог светског рата, када и запоседа поље политике и релације у оквиру међународних односа. Прве теоријске анализе овог концепта наишле су на одређене дилеме, пре свега из разлога спорности израза „национална“, али и израза „безбедност“. Нащионална безбедност је концепт који је више пута, изнова и са другачијим приступом улазио у истраживачко поље теоретичара̂ међународних односа, али и студија безбедности. У годинама иза нас смењивали су се различити приступи и покушаји тумачења, и конструисале истраживачке стратегије које су мање или више успешно обликовали концепт и дале му одређени прихватљив оквир.

У сваком случају, порекло модерног концепта „националне безбедности“, као филозофије одржавања стабилне националне државе, може се пратити од Вестфалског мира, када је концепт суверене државе, суверене владе, постао основа новог међународног поретка националних држава. Познато је и да је Хобс у Левијатану изјавио да грађани подржавају моћне владаре који обећавају крај грађанског и верског рата, дају наду у могућност стварања дуготрајног мира за добробит државе, односно добијају мандат за националну безбедност. Томе се може додати и Клаузевиц, тј. његово размишљање о дипломатији и рату као инструментима за унапређење националне „ствари“, наглашавајући да приказ националне безбедности траже нације које у сваком тренутку штите своје интересе. Овај став је у међународним односима познат као „класични реализам“. 
Имануел Кант је предложио систем у којем се националне државе и њихови национални интереси замењују просвећеним светским поретком, заједницом човечанства, где националне државе подређују националне интересе владавини међународног права ради рационалног увида, општег добра и моралних обавеза. У односу на националну безбедност, добровољно се од стране руководства приступило вишем реду приоритета у односу на националне државе, а то је међународна безбедност. То је условило и развој школе „идеализма“ у оквиру међународних односа.

Као академски концепт, национална безбедност је први пут почела да се проучава у САД после Другог светског рата, који је у извесној мери заменио друге концепте који описују борбу државе за превазилажење разних спољних и унутрашњих претњи. ${ }^{231}$ Како смо већ напоменули, постала је званични водећи принцип спољне политике у Сједињеним Америчким Државама када је 1947. Хари Труман потписао Закон о националној безбедности. Заједно са амандманима из 1949. године, овим чином створени су важни аспекти за америчку националну безбедност, као што су претеча Министарства одбране, подређеност родова војске новој позицији кабинета - ниво секретара за одбрану, основани су Савет за националну безбедност и Централна обавештајна агенција (ЦИА).

Било је на делу сазнање да национална безбедност обухвата далеко више од војне безбедности, иако је од самог почетка потцењено. Закон о националној безбедности (1947) био је тако постављен да „саветује председника о интеграцији унутрашње, војне и спољне политике које се односе на националну безбедност“. ${ }^{232}$

Генерал Максвел Тејлор [Maxwell Taylor] у свом огледу из 1974. године „Тhe Legitimate Claims of National Security“ каже: „Националне вредности у овом

${ }^{231}$ Најранији помен термина национална безбедност јавља се на Јејлском универзитету (Yale University) 1790. године, када је његова референца стављена у однос са домаћим индустријама. Видети: Paleri, Prabhakaran, National Security: Imperatives and Challenges, Published by the Tata McGraw-Hill Publishing Company Limited, New Delhi, 2008, p. 33.

${ }^{232}$ Иcmo, p. 34. 
ширем смислу обухватају средства и националне интересе, као изворе моћи од којих зависи наша будућност као народа. Неке вредне ствари су опипљиве и земаљске, док су друге духовне и интелектуалне. Оне широко варирају од политичких средстава, као што су Закон о правима, наше политичке институције и међународна пријатељства, до многих економских средстава која зраче широм света са високо продуктивном домаћом привредом, подржаном богатим природним ресурсима. Постоји хитна потреба да се штите драгоцености као што су ове које легитимишу и чине суштинску улогу националне безбедности. “233

Када је у питању теоријска мисао, у међувремену се није много напредовало, тако да савремене друштвене науке, политичке науке и још младе студије безбедности и даље имају проблем садржаја и вредносног одређења концепта националне безбедности. Са сигурношћу можемо утврдити да се традиционална схватања могу раздвојити од савремених тумачења националне безбедности.

\subsection{2 Традиционални приступи}

Традиционална или првобитна размишљања о безбедности и њеном запоседању стварности кретала су се на релацији једна држава наспрам друге, у поретку моћи, који је одређен односом претњи и способности да се одговори на претње. Безбедност је описивана искључиво војним појмовима, где су рат и пораз представљали једну од кључних одредница. Такође, изражено је непрекидно надметање у моћи и уравнотежавању снага, као и неизбежно размишљање и понашање у обрасцу безбедносне дилеме. Национална безбедност је имала само стратешке оквире, а претње и способности су се, дакле, исказивале само у војној димензији.

${ }^{233}$ Maxwell D. Taylor, „The Legitimate Claims of National Security“, Foreign Affairs, Vol. 52, 1974, pp. 592-594. 
На основу ових чињеница и студије безбедности су дефинисане као „студије претње, употребе и контроле војне моћи“. ${ }^{234}$ Према овом приступу друштвена стварност је производ деловања материјалних фактора, а друштвени односи, као и безбедносне претње, постоје као објективне чињенице. Када је у питању начин на који се долази до сазнања о друштвеним истинама, користи се позитивистички приступ и/или метод, који подразумева посматрање друштвених чињеница као у природним наукама. При том посматрачки субјект који прикупља чињенице и анализира одвојен је од објекта анализе.

Доминантне школе мисли о међународним односима у другој половини XX века биле су реализам и неореализам. У касним 1960-им, теоријска основа реализма била је изложена критичким питањима на више поља и неореализам се појавио као део тога. Обе перспективе укључују безбедност као основну бригу и њихов приступ безбедности потиче углавном од њихових заједничких претпоставки о свету који најчешће називамо „реалистички свет“. Класични реализам је спознао да проучавање историје може корисно осветлити како су се понашали одређени политички актери. Предмет историјског трагања реалиста био је управо да скицирају важне детерминанте политичког понашања у прошлости које нису биле зависне од ситуације и које су се могле применити кроз историју. При томе су посебно изоловали и фокусирали се на „моћ“ као кључну променљиву у политичком понашању и центру у развоју међународних односа. Моћ је, дакле, централни појам који подстиче реалистичку мисао.

Едвард Кар [Edward Carr] и Ханс Моргентау [Hans Morgenthau], као најзначајнији представници класичног реализма, дефинисали су концепт националног интереса као моћ, при чему је тај концепт представљао и угаони камен политичког реализма и теоријску основу рационалне спољне политике. Рационално чврсто језгро националног интереса представља управо национална безбедност, која је раније означавана као спољна безбедност државе. ${ }^{235}$

\footnotetext{
${ }^{234}$ Stephen M. Walt, „The Renaissance of Security Studies“, International Studies Quarterly, Vol. 35, No. 2, 1991.

235 Драган Симић, Наука о безбедности, Службени лист СРЈ и ФПН, Београд, 2002, стр. 29.
} 
Према размишљањима реалиста и неореалиста, међународни односи као односи између држава леже у основи теорија о моћи и безбедности. Главни предмет су држава, њена моћ и, ако узмемо у разматрање импликације анархије, њена несигурност. Главна недоумица међународне политике, заправо њена дефинициона карактеристика, јесте њена несигурност. Управо ово чини разлику у односу на друге врсте политике, вредне посебних интелектуалних разматрања.

Из данашње перспективе посматрано, такви односи и понашања на међународној сцени прилично су ирационални, јер су се односи између суверених држава заснивали на неповерењу, узајамним преварама и страху. Није била пружена шанса сарадњи у безбедности и свести да се национална безбедност може унапредити уважавањем и поштовањем друге стране и међусобним поверењем. ${ }^{236}$

Либерални институционализам, као нов приступ промишљању безбедности раних седамдесетих година XX века, понудио је и неке другачије идеје и замисли безбедности. Наиме, његови представници су понудили безбедносни образац који се заснива на захтеву да је неопходно развијати сарадњу између чланица међународне заједнице. Да би се то постигло, треба створити услове за унапређење односа између држава успостављањем поверења, утврђивање заједничких начела, норми и правила за сузбијање агресивног понашања, као и уложити додатне напоре за стварање основа за колективно деловање, спречавање сукоба, управљање кризама и изградњу мира.

Теоретичари овог правца истраживања и даље верују да је стање анархије преовладавајуће у међународном систему и да односе у том систему суштински одликује политика силе. Битно их разликује од представника реалиста управо

236 Унутрашња политика је такође представљена на тај начин да може бити бременита несигурношћу, али једино када је ова политика озбиљно изопачена или поремећена, претвара се у неадекватан услов међународне политике. У томе је суштина проблема, зато што ништа друго није битно и не утиче на понашање државе тако дубоко. Та „маленкос““ безбедност (која је увек битна) чини предуслов за све што државе и друштва желе да постигну. 
начин на који се може превазићи такво стање у међународним односима. Наиме, либерални институционалисти су указали на значај међународне сарадње, и то оне која се испољава кроз њено институционално удруживање, као најделотворнијег начина за превазилажење насилних сукоба у односима народа и држава.

Сарадња се највише очекује у пољу политичке, економске и културне сфере, а разматрање укупних међународних односа и светске политике уводи у процес „рачвања глобалне структуре“ и не-државне чиниоце и субјекте. Џозеф Нај [Joseph Nye], као један од истакнутих представника овог правца, указује на разливеност моћи на нове изворе и димензије, као што су приватни субјекти и информације (информатичке способности и ресурси). Моћ једне државе више се не мери величином територије, бројем становника или војним потенцијалом, већ и степеном техничко-технолошког развоја, образовном и старосном структуром становништва, потенцијалом културних добара, начина живота или начина размишљања.

У сваком случају, традиционална схватања безбедности привилегују материјалне елементе у конструкцији теорија и искључују интерсубјективна подручја културе и идентитета из анализе. Очигледно одсуство бриге о култури и идентитету у традиционалним схватањима безбедности мора да се разуме као историјско наслеђе свесног покушаја да се искључе бриге о идентитету из политичког домена.

\subsection{3 Савремени приступи}

Радикалан раскид с традиционалним студијама безбедности почиње мултисекторским приступом истраживању безбедности. Након констатације да постоје и други сектори безбедности поред војног појавила се могућност да има и других референтних објеката безбедности осим државе, на шта су указали и либерални институционалисти. Такође, шири се опсег безбедносних претњи, а њихова природа је условљена и карактеристикама конкретног референтног објекта. 
Дакле, савремена схватања питања националне безбедности знатно су шира од традиционалних, која су се бавила питањима одбране и употребе војске у оружаним сукобима. Савремена схватања се односе на дефинисање укупних интереса и стратегије развитка друштва, али и њихове одбране од угрожавања. Они укључују нове аспекте, као што су економска или еколошка димензија људских права и слобода.

Новообликована безбедносна архитектура условила је значајне социјалне и политичке промене, које, заједно с променама у савременој националној, регионалној и међународној безбедносној ситуацији, представљају јединствени склоп. Национална безбедност је темељна категорија безбедности током Хладног рата, када су се у студијама безбедности постављала и два основна питања: ко је референтни објект безбедности и који су нужни услови за безбедност?

Измењени контекст безбедности крајем XX и почетком XXI века условио је и ширење истраживачког поља безбедности. Тако сада запажамо: 1. ширење истраживачког поља од државе према другим референтним објектима и субјектима безбедности (као што су појединци, друштвене групе, друштво, међународно и глобално окружење); 2. истраживање природе претњи као извора небезбедности; 3. одређивање субјеката одговорних за достизање, очување и унапређење безбедности; и 4. утврђивање стратегије (поступака, начина и средстава) којима се може достићи, очувати и унапредити безбедност на свим нивоима. ${ }^{237}$

Не заборавимо да стандардна јединица безбедности у савременим условима и даље је безбедност суверене националне државе (национална безбедност), која одређује све остале категорије безбедности. Критички приступ безбедности продубио је ранију расправу о концепту безбедности, која је била преуска, поставио је многа питања и разматрао однос традиционалних теорија и безбедносне праксе држава. И поред тога што је поново дошло до стапања безбедности и употребе силе, посебно појавом рата против тероризма, не сме се

${ }^{237}$ Младен Бајагић, Основи безбедности, Криминалистичко-полицијска академија, Београд, 2007, стр. 53. 
пренебрегнути концептуална и методолошка иновација нових теоријских промишљања, која могу бити кључна за разумевање савременог развоја (видети схеме 2 и 8$)$.

У безбедносној теорији се појавила потреба да се шире и продубљеније претресају неке категорије као што је, на пример, идентитет, при чему се у разматрања уводе нови друштвени чиниоци, као што су: идејна основа, антрополошка сазнања, појединачна и колективна психологија, представе, значења, уверења. Тако се снагом друштвених чинилаца може темељно преобликовати материјална структура, што је, према тврђењима појединих аналитичара, својевремено успело М. С. Горбачову. Но, питање је да ли овај изузетак може постати и правило.

Супротно конвенционалним тврдњама, критички приступи наглашавају да су претње производ политичких представљања ситуације. Далеко од тога да је претња чисто спољни феномен на који безбедносне агенције једва да реагују, већ се потенцијална претња трансформише у питање безбедности кроз постепено темељно архивирање података, а потом и интервенцију безбедносних агенција. Обим и озбиљност претњи обликовани су друштвеним, политичким и културним процесима, који производе феномене као што су претње „безбедности“, док су друге занемарене.

Дефиниција специјалних претњи доноси са собом даљи просторни редослед који поставља границе између онога који прети и субјекта којег треба штитити. Традиционално схватање безбедности фокусира се на задатак државе да штити своје грађане и националну територију од непожељних мешања. Ова је преокупација била извор легитимног монопола државе на употребу силе. Међутим, појава избеглица и особа без држављанства (апатрида) од XIX века подстакла је проблем које се не може убројити у ову концептуализацију безбедности, а односи се на питање: ко нуди заштиту онима које не штите државе? Централно критичко питање оних који чине и захтевају алтернативне заштите безбедности састоји се у узимању у обзир политичких чинилаца.

Ово не значи да су наоружање и претње ове или оне врсте измишљене, већ да се значење које им се даје и последична пракса моделују у дискурсу. На тај 
начин се и узрочници небезбедности, који се прихватају за готово и од стране конвенционалних безбедносних наука, доводе у жариште сукобљавања државе и њене небезбедности, препознајући да су обе производ културе. Несигурност није само спољна претња објекту, већ представља и последицу процеса поновног успостављања идентитета објекта. При том је култура поље потенцијално супарничких знакова и представа у којима се воде сукоби око значења.

Дакле, сада се као основни проблем разматра значење. Као што сматра Александар Вент, један од истакнутијих представника социјалног конструктивизма, „људи третирају објекте укључујући и друге чињенице, на основу оних значења које ти објекти имају за њих“. ${ }^{238}$ Ово гледиште се може даље развијати тврдећи да су значења фундаментално културна и могућа путем дискурса или кодова споразумевања, што дају категорије помоћу којих разумемо свет. Питање које можемо поставити гласи: да ли је могуће променити идеје, представе и значења - једном речју, начин мишљења - који ће довести до пожељне промене у самој социјалној конструкцији система, а самим тим и до веће безбедности? Александар Вент сматра да је то тешко, готово немогуће.

Критичари конструктивизма тврде и често замагљују ово питање претпоставком да је друштвена конструкција еквивалентна фабриковању, тј. да ако су претње конструисане, оне у ствари не постоје. Ипак, називање претње друштвеном конструкцијом не оспорава да нуклеарно оружје постоји и да оно може убити и угрозити милионе.

Критичке теорије углавном проналазе мане и грешке у свему што је речено у теорији до тада и сасвим мало се баве конструкцијом решења. Стална критика може утицати само на померање граница постојећих претпоставки, а анализом претпоставки поткрепљује се пракса која произлази из историје и културе. И у том правцу је потребно усмерити изучавање људске стварности. У том правцу се развија и концепт безбедносне културе.

${ }^{238}$ Alexander Wendt, „Anarchy is what states make of it: The Social Construction of Power Politics“, International Organization, Vol. 46, No 2 (1992): 391-425. 


\subsection{4 Национална култура као фактор националне безбедности}

Да би преживела и развијала се, друштвена заједница мора одржавати интегритет заједничке културне оријентације, коју у општим цртама (премда не једнодушно и једнообразно) деле сви припадници као основу свог социјеталног

идентитета. $^{239}$ Сваки члан друштва прилагођава се стилу живота који је од давнина успостављен у групи, а основни културни обрасци мењају се кроз раздобља више генерација. Културни обрасци који настају у дугим временским раздобљима у оквиру великих друштвених група (етничких заједница, националних група и сличних скупина) које живе под истим или сличним животним условима уско су повезани са менталитетом једног народа или друштва.

Квалитативно одређење националне културе, које смо покушали да објаснимо у првом делу, пружа нам могућност да утврдимо како одређена врста културног деловања утиче на развој националне свести, с једне стране, и као ризница знања, значења и вредности (које прожимају све аспекте живота) дефинише начин живота и деловање које ће одговорити свим безбедносним ризицима и претњама, с друге стране.

Културно стваралаштво треба да буде такво да показује отвореност за културну комуникацију најширих размера, али и да истовремено покаже оригиналност у форми и садржају као нешто што ће исказати спремност да се уважи и прихвати специфичност духа људи и народа међу другим људима и народима.

\subsubsection{1 Очување и развој живота људи}

Селекцију вредности, коју врши свака култура, важно је посматрати у контексту развијања механизма развоја људске историје, јер човек помоћу одређених вредности даје известан смисао појединим објектима и облицима живота, а њихово смисао и значење опредељује нас шта ћемо изабрати, а шта

\footnotetext{
${ }^{239}$ Милош Немањић, „Културни обрасци и национални менталитет“, Зборник Института за криминолошка и соичилошка истражсивања 22 (1-2), 1993: 170.
} 
одбацити. Одређујући, дакле, тај „стандард толерантне и пожељне егзистенције“ помоћу културе коју је изабрао, један народ или једна људска група дају специфичан смисао начину живљења. У том смислу се може чак рећи да људски живот нема само биолошко значење, већ и антрополошко одржавање пожељног типа егзистенције.

Култура је управо та компонента која омогућава људима да дефинишу пожељни тип егзистенције, али и да једном усвојене стандарде превазилазе када оквири постану тесни за развијање потреба и аспирација. Међутим, у односу на избор начина живота можда је још важније нагласити управо значај културе за очување живота људи уопште и могућности које пружа да се он даље развија.

У односу на првобитног човека опасности које данас прете савременом човеку далеко су озбиљније и са могућим катастрофалним последицама и за са̂м опстанак живота на планети Земљи, као и опстанак саме планете. Поред глобалних опасности, мноштво је других опасности које су присутне на појединим континентима, регионима или на националном и локалном нивоу, али који каскадним ефектом могу изазвати и глобалне последице.

Улога националне културе у очувању и развоју живота људи огледа се пре свега у чињеници да култура, као начин живота и систем понашања, представља ентитет за себе који је конститутивни елемент друштвеног напретка и историје, и то пре свега кроз кумулативни процес о којем смо већ нешто рекли. Она није ограничена на одређену генерацију у смислу ефеката и утицаја, већ се преноси с једне генерације на другу, а свеукупни потенцијал и могућности које поседује доприносе националном развоју, очувању и развоју живота људи у садашњости и ближој и даљој будућности.

\subsubsection{2 Очување и развој друштва}

Са̂м термин „национална култура“ упућује нас на размишљање да култура више није елитна појава, већ динамична категорија која успоставља интерактиван однос са основним друштвеним вредностима. Говорећи економским речником, култура није трошак, већ инвестиција, а фигурише као 
значајан извор духовне и моралне обнове друштва због вредности које афирмише: социјалну инклузију, партнерство, активно учешће, економски развој и излазак у заједничке јавне просторе.

Данас се култура све више прихвата као важна компонента развоја, чак и као њена суштинска компонента, а обухвата читав низ вредности, као што су идентитет, креативност, обичаји, естетика, знање. Да би се једно друштво развијало, неопходно је да то исто друштво поштује ове вредности, размишља о њима и унапређује их како би успешно планирало и своју будућност.

Култура, дакле, има велики потенцијал за друштвено-економски развој и смањење сиромаштва. При том, развој није само економски раст (што је показао низ неуспелих пројеката током 1970-их година широм света). То је средство за постизање више задовољавајућег интелектуалног, емоционалног, моралног и духовног постојања. Као такав, развој је неодвојив од културе. Култура, у свим својим димензијама, па и у националној, представља основну компоненту одрживог развоја. ${ }^{240}$

Као сектор активности, кроз материјалне и нематеријалне баштине, креативне индустрије и разне облике уметничког израза, култура даје снажан допринос економском развоју, социјалној стабилности, заштити животне средине, али и националној безбедности. Принципи културне разноликости и вредности културног плурализма интегрисани у све јавне политике, механизме и праксе, представљају посебан изазов доносиоцима политичких одлука на локалном и националном нивоу. Крајњи циљ је укључити културу у све развојне политике, било да су у вези са образовањем, науком, комуникацијама, здравством, животном средином или безбедношћу, a, са друге стране, подржати развој националног културног сектора кроз креативне индустрије. На тај начин се

\footnotetext{
240 Јачање доприноса културе одрживом развоју представља циљ који је установљен у вези са светском Деценијом за културни развој (1988-1998). Од тада је напредак постигнут захваљујући корпусу постављених стандарда и инструмената, али и демонстрације средстава као што су: културна статистика, залихе, регионално и национално мапирање културних ресурса.
} 
може значајно допринети смањењу сиромаштва, али и реализовати важне предности у смислу социјалне кохезије. ${ }^{241}$

\subsubsection{3 Очување и развој заједнице}

Национална култура - коју чине јединствен језик, историја, традиција, обичаји - представља основ за постојање и развој једне нације (не само као замишљене заједнице већ и конкретне политичке заједнице) и њене државности, као и услов за опстанак те исте заједнице на одређеном простору и у одређеном времену. Међутим, за развој заједнице, без обзира на то који предзнак носи, култура је ту да оснажи појединце и групе људи пружајући им знање и вештине које су им потребне да утичу на промене у својим срединама. Ове вештине често помажу у изградњи политичке моћи, кроз формиране велике друштвене групе које раде за заједнички програм. Осећај заједништва који постоји у време кризе, на пример, може да се свесно гради. Уколико су заједнице развијене на основу нечега што деле заједничко (да ли простор или вредности), онда је изазов за развој заједнице како инкорпорирати индивидуалност и различитост. Култура кроз аспект образовања помаже члановима заједнице да прошире своје хоризонте друштвене и културне толеранције, што такође доприноси развоју заједнице. Једно од најважнијих средстава за развој заједнице (посебно земаља „трећег света“) јесте ширење програма писмености. Приступ образовању испоручује многе предности: за народ, стручнија радна снага омогућава и бржи економски развој, унапређује национално јединство и социјалну кохезију, учешће у политици, док за појединца значи излаз из сиромаштва, већи друштвени престиж и мобилност, али и изгледе за добар посао.

\footnotetext{
${ }^{241}$ Видети шире: The Power of Culture for Development, Brochure, PDF, UNESCO, 2010.
} 


\section{4 БЕЗБЕДНОСНА КУЛТУРА}

\section{1 Концепт безбедносне културе \\ у различитим контекстима}

Познато је да концепт представља апстракцију, идеју или конструкт који је замишљен као збир или комплекс међусобно повезаних и интерсубјективних значења. Обухвата мање или више категорија које су повезане прецизним везама и разрађене кроз друштвену интеракцију. Интуитивно је готово јасно да концепти имају и неку врсту структуре. Па тако, неки аутори сматрају да концепт мора бити опремљен потребним и довољним условима за њихов опис који недвосмислено одређују екстензију или начин на који ће се он ширити. ${ }^{242}$ Концепти су од виталног значаја за развој научних сазнања. Они помажу да се интегришу наизглед неповезана запажања и појаве у сасвим одрживе хипотезе и теорије као основне састојке науке.

Разумевање и приказ концепта подразумева и неке епистемолошке захтеве. У досадашњем представљању конститутивних елемената културе и безбедности и на даљем развијању концепта безбедносне културе уважили смо неке од њих:

- Као прво, концепт безбедносне културе може да представља производ, артефакт који је настао свесно или несвесно ради прегруписања сложених категорија и поједностављивања стварности.

- Као друго, представља активност, организацију садржаја и дефинисање односа, али и правца у којем ће се кретати појединачне компоненте (култура и безбедност).

\footnotetext{
${ }^{242}$ Internet Encyclopedia of Philosophy, видети: www.iep.utm.edu/concepts.
} 
- Као треће, његово „мапирање“ или обележавање и формирање зависи од постојања актера и њихове интеракције (актери на хоризонталном и вертикалном пољу анализе).

- Коначно, тај концепт није непокретан и статичан, већ у сталној интеракцији са другим посматрачима, са стварношћу и са другим концептима.

Управо ћемо од овог последњег и кренути. Да бисмо конструисали и развили један концепт на разумљив начин, морамо представити сложене односе са мноштвом других концепата с којима је повезан. У тексту који следи бавимо се краћом анализом неких од категорија које у многим својим димензијама имају заједничке елементе или појмовне конструкције са концептом безбедносне културе или једноставно представљају контекст у којем се може тумачити и развијати концепт безбедносне културе.

Да бисмо се на сврсисходан начин упознали са различитим концептима, а затим их и представили као контекст у којем пребива и безбедносна култура, неопходно је да се издвоје неки параметри који ће нам послужити за анализу. Као прво, да утврдимо ширину и обухват предмета који тај концепт обрађује. У оквиру њега важно је евидентирати теоријске појмове које обрађује и којима „манипулише“ у постављању теоријског оквира. Као друго, да утврдимо средства и инструменте којима располаже и на који начин их користи у анализи и тумачењу предмета посматрања. Важно је и одредити вредности које заступа и којима тежи. Често се концепти ослањају и руководе принципима који им дају стабилност и усредсређеност. Не мање су важне и нормативна утемељеност, као и политичка и институционална имплементираност датог концепта. Коначно, важно је јасно и разумљиво представити суштинску идеју коју заступају и циљеве ка којима су усмерени.

У досадашњем излагању, у оквиру другог и трећег поглавља, развили смо оквир у којем смо разложили концепт културе и концепт безбедности, указујући на суштински важне елементе који их уобличавају (мислимо, пре свега, на националну културу, идентитет и националну безбедност) и који ће нам надаље бити замајац који покреће и развија концепт безбедносне културе. 
Пре него што их поново уведемо у оквир анализе, представићемо теоријске концепте који такође сачињавају теоријске изворе концепта безбедносне културе.

\subsection{1 Контекст културе мира}

Одређене политике и поједини филозофи дефинишу мир као најбоље стање односа између људи и група људи, не рачунајући оно што ремети ток редовних постојања, док други развијају више негативан нацрт, који представља мир као одсуство рата; „Мир влада када трговина између народа не садржи војне облике борбе.“243 Иако је област студија мира релативно скорашња творевина, размишљање на тему мира има много дужу историју. Преовладавање насилног сукоба и рата у историји човечанства довело је до многобројних размишљања на тему узрока рата, као и на могућност (или немогућност) „вечног мира“ (наслов познатог и утицајног огледа филозофа Имануела Канта). Демократска теорија мира, која се заснива на Кантовој мисли, претпоставља слободе у држави као предуслов за безбедност између држава. Релативна слобода становништва и навика демократског решавања узајамних спорова виде се у односима између демократских земаља и суштински је део мирољубивих односа или одсуства рата између њих.

Све велике религиозне традиције нуде размишљања на тему мира и рата, мада тек неке апсолутно забрањују прибегавање рату. Као што је одлично запазио Паскал, филозоф XVII века, математичар и посвећени католик: „Људи никада не чине зло тако свесно и одушевљено као када то чине из верских убеђења.“ Религијска мисао заиста нуди огроман и често веома амбициозан корпус рефлексије о моралним ограничењима која окружују са̂м рат. Нарочито је под таквим утицајем била хришћанска традиција.

Култура мира се може дефинисати као „скуп вредности, ставова, начина живота који одбаиују насиље и спречавају сукобе у решавању њихових узрока,

\footnotetext{
${ }^{243}$ Рејмон Арон, Мир и рат између народа, Голден маркетинг, Загреб, 2001.
} 
већ се залажу за решавање проблема кроз дијалог и преговоре између појединца, група и нащија“. ${ }^{244}$ Култура мира је мир у акцији. Настајање таквих култура је дугорочан процес, који захтева и трансформацију институционалне праксе и индивидуалног начина понашања. Коначно, да би опстала и постала уграђена у наше вредности, култура мира захтева ненасиље, толеранцију и солидарност.

Идеја консензуса или стање мира понекад се погрешно тумаче као непостојање сукоба или се за друштва представљају као један хомогенизујући процес. Међутим, у циљу постизања међусобног разумевања, прво мора постојати разлика у погледу пола, расе, језика, вере или културе. Потрага за међусобним разумевањем почиње признавањем ове разлике и вољом да се она превазиђе ради остваривања заједничког циља. Постизање узајамног разумевања штити друштво од самоуништења тако што се изграде темељи, како би се осмислио нов начин да живе заједно. Заиста, узајамно разумевање подстиче одређене вредности од виталног значаја за мир, укључујући и ненасиље, поштовање других, толеранцију, солидарност и отвореност према другима.

Узајамно разумевање не значи хомогенизацију друштва. Напротив, култура мира је унапређивање различитих традиција. Чињеница да заједничка визија произлази из мултикултурног друштва, доказује да је заједнички живот могућ и да ово друштво живи у складу са пулсом културе мира.

Стога, као што се залаже UNESCO, култура мира је нераздвојно повезана са спречавањем и решавањем сукоба. Кључне вредности ове културе јесу, као што је већ наглашено: толеранција, солидарност, размена и поштовање права сваког појединца, принципа плурализма, који осигурава и подржава слободу мишљења, која настоји да спречи сукоб и реши га на извору, укључујући и нове не-војне претње миру и безбедности, као што су искључење, екстремно сиромаштво и деградација животне средине. На крају, она покушава да реши

\footnotetext{
${ }^{244}$ Резолуција УН А/PEC/52/13, Култура мира и А/53/243: Декларација и Акциони програм за културу мира.
} 
проблеме кроз дијалог, преговоре и посредовање, тако да рат и насиље више не буду могући, или макар не буду вероватни. ${ }^{245}$

Када бисмо ове вредности које истиче култура мира упоредили са вредностима безбедносне културе, као и категорије којима полемише, тј. уводи у теоријску расправу, увидели бисмо многе заједничке елементе, али и посебности. Наиме, култура мира се углавном бави насиљем, било да се насиље испољава директно, било да је у темељу неких других појава и феномена. Такође се може говорити о структурном насиљу (индиректном) и културном насиљу (легитимишућем).

Безбедност, а затим и безбедносна култура представљају одговор на много разноврснији и комплекснији спектар ризика и претњи који могу угрозити појединца, друштвену групу, друштво у целини, државу, међународну заједницу. Насиље је само једно од њих. Самим тим су и начин и средства којима се располаже и која покрећу на акцију вишеструко сложенија. Безбедносна култура није само одговор на насиље, већ и перцепција, знање, изграђени ставови, понашање, али и начин употребе насиља као легитимни одраз употребе силе у служби права, када је у питању правна држава.

Потрага за миром и безбедношћу не може се одвојити од културе, од вредности које дефинишу ко смо и шта нам је битно. Када је у питању култура мира, тумачење културе је важно и са аспекта који оправдава или легитимише директно или структурно насиље. Различити људи, народи и етничке групе приступају историјским изазовима на врло различите начине, што смо у претходна два поглавља назначили и обојили бројним илустрацијама и приказима.

Када је у питању безбедност, култура утиче на начин како се виде опасности и претње, како се одговара на њих и којим средствима. Од опасности и претњи, можда је још важније како се виде изазови и да ли се доживљавају као потенцијална претња или као потенцијална погодност која се може усмерити ка развоју и напретку. Културно наслеђе и традиција много ће допринети томе да

${ }^{245}$ Овај став је инспирисан документом Dossier d'information de l'UNESCO, CAB-99/Vs/4, стр. 14; видети: www.unesco.org/cpp/uk/projects/pubs.htm. 
ли се изазовима приступа са унапред позитивним или пак негативним ставом и предубеђењем. Сетимо се Хофстедеа и његове културне димензије - односа према неизвесности.

Практична димензија концепта културе мира може се приказати на основу тога како се ствара и спроводи у свакодневном животу, јер сама идеја мира нема много користи без ослонца у материјалној стварности, из које је иначе и изведена. Тако, на пример, широм света постоје многобројни национални програми за успостављање мира у заједници. Иновативни дизајн, којем се тежи, пружа холистичке и практичне основе у духовно заснованом активном ненасиљу.

Учесници (и творци и директни корисници) програма кроз одређене активности уче да препознају сопствене снаге за израду личне и друштвене промене без насиља и унапреде своје вештине за поштовање ангажмана са противницима, уместо конфронтације која поларизује и демонизује. Питања која се најчешће покрећу у овим програмима јесу: сукоби по разним основама, насиље у комшилуку, у породици, климатске промене, рат и милитаризам, дискриминација, видео-игре, бескућништво, мировно образовање и здравствена заштита. Читави програми се заснивају и на овладавању принципима ненасиља, анализи друштвених промена, изградњи заједнице и вештинама за стварање мира и ресурса̂. Ово су такође и теме које улазе у оквир концепта безбедносне културе.

\subsection{2 Контекст стратешке културе}

Термин „стратешка култура“ први пут је употребљен десет година пре него појам „безбедносна култура“, дакле 1977, код Џека Снајдера [Jack Snyder], у истраживачком раду који се бавио совјетском и америчком нуклеарном стратегијом. $^{246}$ Снајдер је предложио да елите артикулишу јединствене

${ }^{246}$ Jack Snyder, „The Soviet Strategic Culture: Implications for Limited Nuclear Options“, A Project Air Force report prepared for the United States, Santa Monica, CA, RAND Corporation R-2154 AF:5; према: Асле Тоје, „Стратешка култура као амерички алат, историја, могућности, 
стратешке културе које се односе на безбедносно-војне послове, који су шира манифестација јавног мњења, социјализована у посебан режим стратешког размишљања. Тврдио је да, као резултат овог процеса социјализације, скуп општих веровања, ставова и понашања у вези са нуклеарним стратегијама остварују стање „условне трајности“, што их ставља на ниво културе, а не само политике.

Такође, Снајдер примењује свој стратешки културни оквир за интерпретацију развоја совјетске и америчке нуклеарне доктрине као производе различитих организационих, историјских и политичких контекста и технолошких ограничења. Резултат је био његово предвиђање да је совјетска војска у предности за превентивну, нападачку употребу силе и извор за то би се могао наћи у корену руске историје небезбедности и ауторитарне контроле. На крају крајева, Снајдер је тврдио да је стратешка култура „полутрајна“ и нови развој би се посматрао само кроз призму стратешке културе.

Идеја да дубље разумевање културних питања може смањити неуспехе политике и унапредити националне интересе заступљена је у низу америчких стратешких докумената. Напомене о култури могу се наћи и у Европској стратегији безбедности или у другим документима који се односе на питања европске безбедности. Дакле, концепт стратешке културе се, као веома важан појам, нашао у пољу безбедности. Као што је тврдио и Алистер Јан Џонстон [Alistair Ian Johnston], „различите државе негују различите доминантне стратешке приоритете који имају корене у раним или формативним искуствима државе, и у извесној мери су под утицајем филозофских, политичких, културних и когнитивних карактеристика државе и њених елита“. Неисторијске, или „објективне“ варијабле, као што су технологија, поларитет или релативне материјалне могућности, све су секундарнијег значаја.

геополитика и вредности: пример ЕУ“, Безбедност Западног Балкана, Стратешка култура и реформа сектора безбедности, бр. 14, 2009. 
Алистер је иначе дао једну од најпознатијих дефиниција стратешке културе као „систем симбола састављен од два дела“. 247 Први део обухвата основне премисе о редоследу стратешког окружења, на пример, улогу рата у међудржавним односима, природу непријатеља и претњи које она представља, ефикасност употребе војне силе и услове под којима је војна сила употребљена. Други део је оперативног карактера и у вези је са најефикаснијим избором за борбу против претњи. ${ }^{248}$

Колин Греј (1981) такође сугерише да препознатљив национални стил, са „дубоким коренима у оквиру одређеног тока историјског искуства“, карактеришу израде стратегије у земљама као што су Сједињене Државе и Совјетски Савез. Он је дефинисао стратешку културу као да се „односи на начине мишљења и деловања у односу на снагу, што произлази из схватања националног историјског искуства, од аспирација према одговорном понашању у националном смислу“, па чак и од „грађанске културе и начина живота“. Дакле, стратешка култура „даје миље у којем се расправља о стратегији“ и служи као одређен независан стратешки политички образац. Као и Снајдер, Греј је држао да ће стратешка култура имати полутрајни утицај на безбедносну политику.

Док су ови аргументи скренули пажњу на улогу домаћих услова у обликовању политике националне безбедности и понашања, критичари су тврдили да је операционализација стратешке културе, такође, била проблематична и субјективна. Они су предложили да су стратешки културни модели таутолошки, јер би било готово немогуће раздвојити независне и зависне варијабле на поуздан начин. Критичари су такође оптерећени ставом да су стратешке културне интерпретације по дефиницији јединствене, цртане по уској и контекстуалној историографији колико и антропологија. Осим тога, и присталице и противници су веровали да је концепт стратешке културе био прилично статичан, фокусирајући се на трајне историјске оријентације са

\footnotetext{
${ }^{247}$ A. I. Johnston, „Thinking about Strategic Culture“, International security, Vol. 19, No 4, Spring 1995, pp. 32-64.

${ }^{248}$ Исто, стр. 46.
} 
моћним предиктивним способностима. То је оставило мало простора за развој транснационалних истраживања о овом феномену.

Пишући у свом тексту о геополитици супермоћи, Греј је оценио да „друштвене науке нису развиле тачну методологију за утврђивање посебности националних култура и стилова“. Литература о „,академски немодерном предмету националног карактера“ у најбољем случају је непоуздана (што смо у првом и другом делу рада већ приметили), али је веровао да је учење о „културним мислима“ једног народа од пресудног значаја за разумевање понашања земље и њене улоге у светској политици. ${ }^{249}$

Бут $[K$. Booth $]$ је назвао оснивање војне стратегије „посебним етноцентричним пословањем“, тврдио је да стратешка култура „утиче на облик у којем је једна држава у интеракцији са другима у вези са безбедносним мерама“. Као што је такође навео: „Она укључује националне традиције, навике, вредности, ставове, начине понашања, симболе, приступе и специјалне процесе који су изабрани да утичу на спољну средину и начине решавања проблема лицем у лице са претњама или коришћењем силе.“250

Концепт културе у безбедности, а посебно концепт стратешке културе, наглашава стереотипне погледе на друге културе и игнорише нијансе политичких институција, геостратешки контекст и специфичности лидера. Штавише, разумевање релевантних политичких институција, идентификовање основних друштвених актера и елита, као и признавање ограничења и подмићивања који мотивишу акцију, захтевају специфична знања о случају. Може се разумети као позивање на културно знање. Међутим, то није исто што и идентификовање дубоко укорењених културних предиспозиција за одређено стратешко понашање.

Један други аутор, Кристофер Твуми [Christopher P. Twomey], тврди да је литература о стратешкој култури, како је традиционално замишљена,

${ }^{249}$ Colin Gray, The Geopolitics of Superpower (Lexington, Kentucky: University Press of Kentucky, 1988), pp. 42-43.

${ }^{250}$ K. Booth, New Thinking about Strategy and International Security, Harper Collins Academic, London, 1991. 
непримерено стекла легитимитет на основу успеха у сличној ситуацији рада на војној организационој култури и конструктивистичког националног идентитета. Твуми прави разлику између литературе која је усредсређена на војну културу и оперативне последице, на традиционалну стратешку културу, која се односи на анализу велике стратегије, и, на крају, на оне које објашњавају национални идентитет и интересе.

Прво, он се управља на војну организациону културу која објашњава оперативне или пак тактичке поставке и тенденције. Она испитује различите културе унутар различитих војних служби које обликују услуге какве-такве војне мисије или истичу оне које су избегнуте. Они се фокусирају на културне факторе у посебним организацијама: или једнонационалне војске или одређене услуге пре него националне културне особине. Друго, он испитује традиционалну стратешку културу, која повезује дубоко укорењене и националне културне праксе и веровања који доприносе избору велике стратегије, обе са војним и политичким елементима. Ова категорија се односи на специфичне културе, широке војне стратегије и праксе.

У својој најновијој публикацији Војни објектив Твуми показује како су различите војне доктрине довеле до погрешне представе између САД и Кине, пре свега, преко спољне политике - као потенцијалне опасности које се могу представљати у будућим односима. ${ }^{251}$ Због њихове различите стратешке ситуације, историје и војне културе, нације могу имати радикално различите дефиниције ефективне војне доктрине, стратегије и могућности. Такође, Твуми тврди да када се такве доктрине - или „теорије победе“ - разликују од државе до државе, па тако и добијају погрешне представе о могућностима ривала и намерама, појављује се и лажни оптимизам у погледу сопственог учешћа. Заузврат, они могу да представљају препреку за међународну дипломатију и државништво, тако што отежано комуницирају и договарају се о процени односа снага. Када се државе укључе у стратешке принуде - или да одврате или

${ }^{251}$ Christopher P. Twomey, The Military Lens: Doctrinal Difference and Deterrence Failure in SinoAmerican Relations (Cornell Studies in Security Affairs), Cornell University Press, Ithaca and London, 2010. 
да приморају на акцију - такви проблеми могу да доведу до ескалације сукоба и рата. ${ }^{252}$

Данас се, готово са сигурношћу, истичу размишљања која поистовећују концепте стратешке и безбедносне културе, посебно када се говори о обликовању оријентације државе на међународном плану према питањима безбедности и дефинисању одбрамбене и безбедносне политике.

\subsection{3 Контекст политичке културе}

Концепт политичке културе израз је потребе да се повежу два домена, с нагласком на политичким ставовима или претпоставкама различитих група људи и начинима на које су ти ставови изграђени код њих. Ту фразу су шездесетих година XX века користили интелектуалци који су се бавили политиком, али је она ушла у дискурс историчара касних осамдесетих, што се може закључити бар по насловима неких књига: Политичка култура старог режима [The political culture of the old regime] Кита Бејкера, Политика, култура и класе у Франиуској револущији [Politics, Culture and Class in the French Revolution] од Лин Хант и сличних. ${ }^{253}$

252 Твуми процењује широку лепезу извора у обе војне доктрине (САД и Кина), стратешке културе, погрешне представе, и теорије одвраћања - на покушају да изграде студију случаја на стратешкој принуди у току кинеско-америчког конфликта у Кореји и Тајванском мореузу у првим годинама после Хладног рата - као и испитивање сличних питања у арапскоизраелском сукобу. Напокон, показујући како су ови фактори допринели сукобима из прошлости, Твуми довољно документује упорност опасно лоших комуникација у савременим кинеско-америчким односима. Његова јединствена аналитичка перспектива у погледу војне способности указује на то да креатори политике треба пажљиво да размотре војне доктрине народа на које они покушавају да утичу.

253 Лин Хант се у својој студији о Француској револуцији усредсредила на промене „правила политичког понашања“ и посебно на нове „симболичке праксе“, којима је приступила у фукоовском маниру. Те праксе су варирале од кореографије јавних фестивала до ношења тробојне кокарде или црвене капе слободе, фамилијарног ословљавања сваког, које симболизује једнакост и братство, те се тако малим гестовима доприноси остварењу поменутих идеала. 
Политичка култура се може тумачити као специфичан начин живота који утиче на формирање „духа времена“, на основу којег се кристалише одређена пракса деловања и понашања, као и облици друштвене партиципације грађана. Према Роберту Такеру [Robert Tucker], политичка култура одређује, пре свега, матрицу или тип оријентације друштва за политичке акције, односно садржи скуп значења и циљева у којима се оличава даิти политички систем. ${ }^{254}$

Политиколози Алмонд и Верба покренули су студије високог профила, које су се бавиле концептом политичке културе 1960. године, дефинишући га као „Подскуп веровања и вредности друштва које се односе на политички систем“. Политичка култура, како су говорили, представља посвећеност вредностима као што су демократски принципи и институције, идеје о моралу и употреби силе, права појединаца или колективитета, као и предиспозиције за улогу земље у глобалној политици. Такође су нагласили да се политичка култура манифестује најмање на три нивоа: когнитивном, што укључује емпиријска и каузална уверења, вреднујућем, који се састоји од вредности, норми и моралних судова, као и експресивном и афективном, који обухвата емоционалне везаности, обрасце, идентитете и лојалности и осећања афинитета, одбојности или равнодушности. Парсонс додаје да се култура састоји од „тумачења кодова“, укључујући језик, вредности, па чак и суштинска веровања, као што су подршка за демократију или узалудност рата.

До 80-их година XX века, интердисциплинарне студије које повезују културу и политику добиле су на популарности. Социолог Ен Свидлер предложила је сложенији модел веза између културе и државе, понашање, посредством културних „стратегија деловања“. Свидлер је дефинисала културу прилично широко и према њој она се састоји од „симболички опремљеног значења, укључујући и уверења, ритуалне радње, уметничке форме и церемоније, али и неформалне културне праксе, као што су језик, оговарања/гласине, приче и ритуали свакодневног живота“. Надовезујући се на аргументе Вебера и

\footnotetext{
${ }^{254}$ R. Tucker, „Political Culture and Communist Society“, Political Science Quarterly, vol. 88, No. 2, 1973, p. 3.
} 
Парсонса, она тврди да су интереси важан погон за доношење стратегије и посредовани услов за државно понашање.

У сваком случају, може се рећи да политичку културу чине: политички систем, политичке традиције, политичке институције, начин на који се доносе одлуке, вера и религија, стратешка култура и, можемо слободно додати, безбедносна култура. Познато је да идентитет обезбеђује основу за колективно јединство и мобилизацију, али политика обезбеђује инструменте и средства за мобилизацију колективне акције и доводи до резултата. Политичка култура је динамична и променљива, јер је историјски производ.

Неки фактори који доприносе стварању одређене политичке културе обухватају историјско искуство, верску традицију, колективне вредности, темељне принципе, географску локацију и конфигурацију, стратешко окружење (на пример, релативна рањивост или безбедност), економске капацитете и демографију. Овде примећујемо колико има фактора који су заједнички и који опредељују како обликовање и развијање политичке, тако и безбедносне културе.

\subsection{4 Контекст организационе културе}

Попут друштва, друштвене групе или неког другог ентитета, и организације имају своју културу по којој се препознају и разликују једна од друге. Појам потиче из теорије групне динамике К. Левина [Kurt Lewin], који је крајем 30-их година XX века развио теоријске поставке и дефинисао нове истраживачке поступке у изучавању групне атмосфере и њених ефеката, начина на који се води групна дискусија и групно одлучивање за обликовање понашања чланова групе. Закључци и крајњи резултати групне динамике веома су лако применљиви на организацију (привредну или неког другог карактера), с обзиром на то да и она представља групу коју чини скуп организованих и вођених појединаца.

Ипак, најпознатији теоретичар који се бавио организационом културом, Едгар Шајн [Edgar Schein], развио је концепт и дефинисао појам организационе 
културе као „образач заједничких основних претпоставки на основу којих је група научила како да решава проблеме спољне адаптаичје и унутрашње интегращије, а формулисане су довољно добро да се могу сматрати вредним и као такве преносити новим члановима организащије, као исправан начин периепиије, размишљања и осећања за исте проблеме“. ${ }^{255}$

Организациона култура се дефинише на основу интеракција запослених на радноме месту и условљена је њиховим животним искуством, снагама и слабостима, образовањем и васпитањем. Она се такође заснива на заједничким ставовима, веровањима, обичајима, експлицитним или имплицитним уговорима, и писаним и неписаним правилима на основу којих се организација развија током времена и који су функционисали веома успешно да би се сматрали важећим. Други назив за организациону културу који се сусреће у литератури јесте корпоративна култура и може се рећи да се манифестује у следећем: 1. начину на који организација обавља свој посао, третира своје запослене, клијенте, као и ширу заједницу, 2. мери у којој су аутономија и слобода дозвољене у доношењу одлука, развијању нових идеја и личном изражавању, 3. начину на који моћ и проток информација пролазе кроз хијерархију и 4. снази запослених и обавезама према колективним циљевима. ${ }^{256}$ Организациона култура усмерава или чак одређује свест и понашање људи и доводи до тога да чланови организације на приближно исти начин интерпретирају и разумеју појаве у свету око себе. Како реакције људи произлазе из њихове интерпретације света и догађаја у њему, јасно је да култура усмерава и одређује и свакодневно понашање и активности људи.

Иако постоје многи заједнички елементи у великим организацијама било које земље, организациона култура је особена за сваку организацију и најтеже се мења. Полазећи од основних вредности и оријентација које преовладавају у друштву, свака организација дефинише своје вредности и ствара норме понашања, а све с циљем стварања специфичних циљева и утврђене стратегије.

\footnotetext{
${ }^{255}$ Edgar H. Schein, The Corporate Culture Survival Guide: Sense and Nonsense about Cultural Change, San Francisco: Jossey-Bass Publishers, 1999.

${ }^{256}$ www.businessdictionary.com/definition/organizational-culture.html, приступљено 27. 1. 2012.
} 
Како ће се обликовати и развијати специфична култура организације зависи и од многих других објективно постојећих фактора спољашњег окружења. Међу њима су економски, социјални фактори, друштвено-политичко уређење, степен научно-технолошког развоја, безбедносни разлози и други.

Ипак, веома су важни унутрашњи фактори који, између осталих, обухватају мисију, стратегију и технологију организације. Док руководство и врховни менаџмент играју велику улогу у дефинисању организационе културе кроз своје поступке и лидерство, сви запослени доприносе организационој култури. Руководство организације је управо заслужно за формулисање и обликовање филозофије организације, која одсликава циљеве, вредности, уверења, идеје које се најбоље оваплоћују у личности оснивача и председника (или генералног менаџера).

Како се најчешће узима модел организационе културе као модел истраживања процене квалитета безбедносне културе у оквиру организационог нивоа истраживања, то је јасно колико су ова два концепта блиска и заснована на одређеним вредностима и веровањима утемељеним у одређеној култури (националној, професионалној, групној и тако даље). Различити аспекти културе суштински одређују понашање актера неке организације и њихов однос према послу, окружењу и питањима безбедности, посебно ако су од кључног значаја за опстанак пословних идеја, целокупног пословања, укључујући и остваривање профита. Поред тога, важно је сачувати и заштитити људске и материјалне ресурсе од свих облика отуђења или угрожавања.

Као и свака друга организација, и оне које су у оквиру безбедносних структура, као што су војска, полиција или обавештајно-безбедносне агенције, имају сопствену, особену културу. Култура одређује и начин на који те организационе целине реагују на различите ситуационе изазове. Она такође доследно обликује то како војник (војсковођа), полицајац, обавештајац посматра околину и како се припрема да реагује на тренутне и будуће изазове. Посебно је интересантно како се ове организације прилагођавају променама и иновацијама, које могу значајно померати „правац кретања“ и стратешка опредељења на основу којих треба да заузму потпуно нови курс деловања. 
Војска, као једна од најпоузданијих организација, али уједно и класична бирократска творевина, много се теже и/или спорије прилагођава променама управо због превеликог ослањања на утврђене процедуре и хијерархијску структуру. Иновација је сложен процес, који није ни линеаран нити увек очигледан. Историјски и стратешки контекст у оквиру којег се врши војна трансформација подржава ову комплексност. У војним безбедносним структурама култура која се негује мења се најтеже, а сваку промену је тешко схватити и прилагодити јој се.

Као што смо већ приметили, свака организација има јединствену културу, која покреће облик, степен и брзину промена̂-иновацијаิ. Да би се иновација усталила, неопходно је да је подстичу и прихватају сви запослени на свим нивоима. Промена се неће укоренити уколико је не прихвате високи лидери, уколико не верују у њену вредност, што је нарочито специфично у традиционалним хијерархијским организацијама, попут војске. Оног тренутка када се прихвати, спровођење и примена се одвијају много лакше и ефикасније него у свим другим институцијама и организацијама у друштву.

\subsection{5 Контекст ,safety“-културе (културе безбедности и заштите на раду)}

Енглески термин safety у српском језику је преведен као „сигурност“ или „безбедност“, а у концепту „safety“-култура односи се на заштиту од удеса. Наука заштите на раду односи се на здравље и добробит људи на послу и у другим активностима. Овај концепт смо узели у разматрање, јер је веома значајан за организациони ниво сагле́дања сигурности и безбедности на раду.

Сигурност и безбедност су појмови сличног значења, у тумачењу подупиру један другог, али ипак постоји разлика која се може уочити управо на примеру концепата које граде, а који наступају упоредо један поред другог - дакле, концепти safety- и security-културе. У теоријском смислу се увелико разматрају њихов однос, могуће подударности и заједничке карактеристике, као и потенцијалне разлике. 
Најдужа традиција истраживања сигурности потиче из високо ризичних индустрија, укључујући и нуклеарне електране, испоруке у близини обале или места рада (производње нафте и гаса) и превоз. Моделовање несрећа може обухватити технолошке, људске и организационе факторе. Ипак, фокус је углавном на ненамерним инцидентима. Када говоримо о безбедносној култури [security culture], укључујемо намеру као кључну одредницу према којој је усмерено деловање овог концепта. Безбедносна култура ставља додатни акцент на смишљене поступке, који су намеравали да проузрокују штету. Пошто се безбедност бави намерним делима, безбедносна култура захтева различите ставове и понашања када су у питању, на пример, поверљивост информација и напора да се спрече злонамерне радње, у поређењу са културом заштите на раду.

У литератури се налази више дефиниција културе заштите на раду, једна често цитирана представља је као: организаџиону атмосферу у којој се безбедност и здравље на раду, подразумевају и прихватају као високо приоритетне области рада. Она је производ појединачних и групних вредности, ставова, периепичја, надлежности, као и обрасии понашања који одређују посвећеност, као и стил и стручност организачије здравља и управљань сигурношћу. ${ }^{257}$ Слична је и речничка дефиниција: начин на који компанија или организащија мисли, планира, управља сигурношћу или безбедношћу својих запослених и клијената, посебно када се њихова сигурност сматра једном од најважнијих ставки. ${ }^{258}$

Прегледом литературе која се бави природом културе заштите на раду и њеним различитим аспектима јасно се може уочити перманентан напредак у њеној теоријској концептуализацији. Такође, евидентне су две врсте напора које улажу истраживачи у овој области: први је теоријско разграничење од сличних појмова, као што су сигурносна клима ${ }^{259}$ и организациона култура, такође

${ }^{257}$ S. Cox, R. Flin, „Safety culture: Philosopher's stone or man of straw?“, Work \& Stress, 12 (3), 1998, pp. 189-201.

${ }^{258} \mathrm{http} / / /$ dictionary.cambridge.org/dictionary/business-english/safety-culture

${ }^{259}$ Нисканен објашњава сигурносну климу на следећи начин: Сигурносна клима се односи на скуп атрибута који се могу сматрати деловима радних организащија и који могу бити 
security-култура, као и стварање општеприхваћене дефиниције safety-културе са јасно прецизираним елементима.

Међутим, свеобухватна анализа теоријских и операционалних дефиниција safety културе открива да, и поред неуједначености и супротних схватања суштине овог појма, највећи број аутора се слаже у следећем: 1) safety-култура је концепт дефинисан на нивоу групе или вишем, који се односи на заједничке вредности међу свим члановима групе или организације, 2) safety-култура се бави формалним питањима безбедности у организацији, и блиско је повезана са, али није ограничена, управљањем и надзорним системом, 3) safety-култура наглашава допринос свих на сваком нивоу организације, 4) safety-култура организације има снажан утицај на понашање својих чланова на послу, 5) safety-култура се обично рефлектује у непредвиђеном догађају између система награђивања и безбедносних перформанси, 6) safety-култура се огледа у спремности организације да се развија и учи на грешкама, инцидентима и акцидентима, 7) safety-култура је релативно трајна, стабилна и отпорна на промене.

Концепти safety-културе и security-културе у данашњим оквирима представљају управо оне сегменте/димензије корпоративне културе који највише утичу на успех у пословању великих корпорација, оснажујући и доприносећи корпоративној безбедности. Концепти културе сигурности и културе безбедности, први старији, а други нешто млађи, већ извесно време се крећу путем интеграције и помоћи стратешком менаџменту безбедности да обавља координацију и управљање сигурношћу и безбедношћу.

Као погодна илустрација да је то ипак могуће и да се о томе већ озбиљно размишља може да послужи пример нуклеарне безбедности. Нуклеарна сигурност и безбедност развиле су заједно другачије трајекторије у последњим деценијама. Режим који подржава нуклеарну сигурност - комбинацијом

изазвани политиком и праксом које су те организације наметнуле својим радницима $и$ супервизорима. Видети: Т. Niskanen, „Safety climate in the road administration“, Safety Science, 17, 1994, pp. 237-255. 
националних закона и прописа, међународних уговора и добровољних конвенција - сазрео је убрзо после удеса у Чернобиљу.

Нуклеарни безбедносни режим, с друге стране, у великој мери је напредовао у одговору на терористичке нападе 11. септембра 2001. године у САД. Тако и Међународна агенција за атомску енергију [IAEA] све више уочава постојање међусобне повезаности ова два концепта, с обзиром на то да је и отворила Одељење за нуклеарну сигурност и безбедност [Department of Nuclear Safety and Security], иако та питања још нису чврсто интегрисана међу државама чланицама. У извештају Међународне групе за нуклеарну сигурност (INSAG24, налази се у оквиру IAEA) из 2010. године закључено је да „нуклеарне електране имају користи од софистищираног и свеобухватног сигурносног режима који је успостављен током година ... док је безбедносни режим за нуклеарне електране далеко мане развијен од сигурносног режима“. ${ }^{260}$

Управо због специфичности и посебне рањивости нуклеарних постројења, сасвим је оправдано на овакав начин сагле́дати све аспекте сигурности и безбедности те настојати да се ти концепти приближе један другоме и да кроз интегрисан приступ на највишем нивоу омогуће најбољу заштиту те рањивости. $^{261}$

Уочавање важности паралелног развоја концепта „safety“- и „,security“-културе у пракси, њиховог сталног развоја и унапређења у оквиру корпоративне културе у блиској прошлости непосредно је повезано са појавом драматичних догађаја у високоризичним индустријама. Међутим, у садашњим условима интензивног напретка различитих корпорација и опасности које им прете, јасно је да су култура сигурности и безбедности међусобно повезане и условљене на свим нивоима организационог пословања. Оне заправо све више представљају неопходан услов успешног функционисања безбедносног менаџмента у свим

\footnotetext{
${ }^{260} \mathrm{http} / / /$ www-pub.iaea.org/MTCD/publications/PDF/Pub1472_web.pdf

${ }^{261}$ Више о томе погледати: S. Stanarević, J. Gačić, V. Jakovljević, „Integrating the concept of safety and security culture in the corporate security“, Corporate security in dynamic global environment challenges and risks, ed. Denis Čaleta, Institute for Corporative Security Studies - ICS, Ljubljana, 2012, pp. 101-115.
} 
организацијама. У том смислу се и очекује да организације, без обзира на врсту делатности на коју су усмерене, морају обезбедити да ове две културе егзистирају једна поред друге.

Две културе могу да се развијају и подржавају ако се равноправно промовишу на државном нивоу и од стране менаџера заинтересованих организација, као и појединаца који играју јасну улогу у њиховој примени. Тешко је предвидети спајање ове две културе у једном ентитету, оне морају, међутим, коегзистирати и појачавати једна другу међусобно. Дакле, оне се међусобно обогаћују, па је чак потребно тражити и развијати могућу синергију између њих, а за ове концепте је важно и успоставити механизме како би се одвијала стална размена информација, искустава и позитивних пракси. Наравно, важно је и посматрати их и анализирати у контексту могуће упоредивости, где би се јасно издвојиле тачке спајања, али и тачке раздвајања, када је у питању теоријска и практична граница деловања ових концепата.

\subsection{6 Контекст концепта ,друштвене самозаштите“}

У свим претходним концептима као очигледну повезаност са концептом безбедносне културе, пре свега, примећујемо појам културе који је заједнички за све. Дакле, узимање у обзир елемената културе као што су вредности, веровања, симболи и друге, да би се објаснило зашто је и у којим околностима или у којем контексту потребно разматрати развој друштвених односа, односа између држава на међународном плану или интерперсонални однос актера у бројним ситуацијама свакодневног живота. Када је у питању концепт друштвене самозаштите, ствари стоје мало другачије.

Концепт друштвене самозаштите представљао је развијен, релативно издиференциран политичко-правни појам, који се усталио у социјалистичком самоуправном друштвеном систему (пре свега некадашње СФРЈ). Услови за његово конституисање и развој налазили су се у суштинској промени улоге државе у самоуправном друштву. Одумирање, али и демократизација бројних државних функција (делатности), које су се остваривале преко државног 
апарата и система његове организације, наговештавале су нови облик остваривања, трансформацијом тих функција у функције самоуправног друштва. $^{262}$ Овај концепт је заправо говорио о подруштвљавању безбедности, нечему што се у савременој литератури налази под одредницом „друштвена безбедност“. Дакле, генеричка суштина друштвене самозаштите изражена је у подруштвљавању вршења послова безбедности и заштите, чиме се уједно отвара и процес постепеног враћања једне доста дуго изразито државне функције у надлежност друштва.

Концепт друштвене самозаштите се заснивао на измењеном односу друштводржава-појединац, по којем се према заговорницима и теоретичарима овог концепта, први пут у класном развоју човечанства безбедност земље организује и заштита виталних вредности друштва остварује са позиција не само државе већ и друштва и појединца. При том се о држави размишљало као о институцији или творевини која одумире. Када данас говоримо о подруштвљавању безбедности, мислимо да се та област разлива и постаје домен рада и других субјеката, а не само државе и њених органа, при чему се то не дешава зато што држава „одумире“, већ само одређене послове и активности везане за безбедност преноси и на друге учеснике друштвеног живота. Уз то се узимају у обзир сложеност и мноштво безбедносних ризика и претњи којима савремено друштво обилује и на које не могу успешно одговорити једино држава и њени органи, већ се морају укључити и шири друштвени слојеви и субјекти.

У разјашњењу и тумачењу самог појма друштвене самозаштите издвојила су се три гледишта: једно које је полазило од формалноправних елемената, друга група гледишта која је покушала да одреди социолошки аспект друштвене самозаштите и трећа група која је покушала да одреди политичко-правни појам друштвене самозаштите.

Формалноправна гледишта сагле́дају појам друштвене самозаштите претежно као категорију правног система. Доминантан је позитивноправни израз,

${ }^{262}$ Никола С. Иванчевић, Друштвена самозаштита, Факултет народне одбране, Универзитет у Београду, Београд, б.г., стр. 23. 
одређен у одговарајућим правним актима, при чему се заступа мишљење да правни систем признаје своју несавршеност у погледу домета правне заштите, иза које стоји санкција, због чега допушта самозаштиту, као допунско средство. Највећи број заступника овог гледишта суштину појма друштвене самозаштите тражи у уставноправним и законским одредбама. ${ }^{263}$

Заступници социолошког приступа у тумачењу друштвене самозаштите полазе од социолошких категорија: државе, друштва, етатизма и самоуправљања, функција и делатности. У одређивању појма заштитне функције друштва не налазе адекватне аргументе који ће потврдити да се извори друштвене самозаштите налазе и у најстаријим раздобљима историјског развоја човека. Наиме, настанак друштвене самозаштите они везују тек за појаву пролетаријата и његовог идејног опредељења, за остваривање заштитне делатности преко наоружаног народа. ${ }^{264}$

Политичко-правни приступ друштвеној самозаштити полази од утврђивања основних друштвених односа у самоуправном друштву, пре свега производних. При том се посебно посматрају положај човека и његова права и слободе. Затим су предмет посматрања власт, начин њеног остваривања и вршења, као и степен отуђености од друштва и радног човека. Истовремено са проучавањем реалних политичких и друштвених односа, као елемената појма, посматра се и

${ }^{263}$ Постојала је и уставна одредба о друштвеној самозаштити по којој је она представљена као „функција самоуправног друштва, која се остварује активностима радних људи, грађана, организаџија удруженог рада и других самоуправних организащија и заједница, друитвенополитичких и других организаџија и друштвено политичких заједница, ради заштите уставног уређења, самоуправних права радних људи и других права и слобода човека $и$ грађанина, ради заштите друштвене имовине, обезбеђивања личне и имовинске сигурности радних људи и грађана и ради слободног друштвеног развоја“. Видети: Велизар Н. Најман, Основи друштвене самозаштите, Привредна штампа, Београд, 1979, стр. 142.

264 Тако се према њима теоријски зачеци концепта друштвене самозаштите налазе у оним идеолошким основама пролетаријата који говоре о наоружаном народу, националној гарди, одборима будности (vigilance), пролетерској и народној милицији, радничкој контроли, сеоској стражи, народној одбрани, а њени практични извори налазе се у бурним револуционарним временима Париске комуне (1871), првим данима након Октобарске револуције у Русији и социјалистичкој револуцији југословенских народа (1941-1945). 
правно значење друштвене самозаштите, као уставне категорије, јер се остварује у правној држави. Дакле, значење друштвене самозаштите проналази се у правној норми, односима са другим институтима правног система, али и у склопу односа и промена које она изазива у целокупном друштву.

У складу са овим поставкама дата је и дефиниција друштвене самозаштите која гласи: Друштвена самозаштита је активност свесно организованог система друштва-државе усмереног на остваривање потребне унутрашње и спољне безбедности земье и неопхоне заштите виталних вредности друштва од свих облика неоружане агресије, контрареволуције и свих врста угрожавача, при чему се посебан значај даје онима који су управљени на угрожаване јавног реда и мира и минимума животног стандарда радних људи и грађана, а у циљьу остваривања објективно неопходне стабилности самоуправног друштва Сочијалистичке Федеративне Републике Југославије. Или, сажетије речено: друштвена самозаштита је систем и политика објективно могућег подруштвљавања послова безбедности и заштите друштва-државе. ${ }^{265}$

Велизар Најман је даље навео да је друштвена самозаштита у садржинском смислу конституисана као политика безбедности, самоуправне контроле, сузбијања целокупне социјалне патологије и заштите минимума животног стандарда обезбеђеног уставним системом државе и складног система самоуправних субјеката са класичним субјектима друштвене самозаштите.

Као политика безбедности она је требало да обезбеди: заштиту уставног поретка, личне и имовинске сигурности радних људи и грађана, заштиту слободног друштвеног развоја, развијања патриотизма и безбедносне културе и упознавање радних људи и грађана са садржајем, методом и облицима непријатељског деловања. Овде је већ уочена употреба термина безбедносна култура, иако у датој литератури још није јасно дефинисана. Назире се њен аспект деловања у сфери васпитања и образовања, тј. стицања потребних знања о садржају, методама и облицима деловања носиоца угрожавања и активности на пољу откривања, спречавања и заштите од друштвено штетних и негативних

${ }^{265}$ Велизар Н. Најман, Основи друштвене самозаштите, Привредна штампа, Београд, 1979, стр. 37. 
појава и радњи. И као таква се, са наглашеним образовним карактером, и до данас задржала на овим просторима. ${ }^{266}$

\section{2 Појам и основне теоријске поставке безбедносне културе}

Безбедносна култура се, са савременога гледишта, односи на начин на који се развијају одређене идеје о безбедносном поретку и структури, као и ономе што смо уочили као опасност по наше животе или претњу за наше вредности, а уједно је и наша најочигледнија одбрана од њих. Безбедносна култура учествује у обликовању онога што је драгоцено за нас. Регулише наше моралне, економске и политичке приоритете. Она такође поставља ограничења и могућности за декларисање шта је важно, вредно или није вредно, шта заслужује заштиту или не.

Пре терористичког напада од 11. септембра 2001. идеја безбедносне културе је опстајала као прилично уопштен и апстрактни концепт. Безбедносно окружење многих држава у међувремену се драстично променило, а концепт безбедносне културе добио је и много јасније обрисе. Данас, присуство и развијеност безбедносне културе значајно помаже да се осигура да безбедносни разлози буду узети у разматрање при доношењу стратешких одлука (држава, друштво или појединац), без обзира на то да ли су ове одлуке део државне спољне и безбедносне политике или политике неког другог ентитета.

Чињеница је да су појам и концепт безбедносне културе релативно кратко у истраживачком пољу теоретичара̂ студија безбедности, али се у прихватљивој и значајној мери промишља и анализира код истраживача и теоретичара, најпре, западних друштава. Према доступној литератури уочено је да се користи и развија нешто више од две деценије. Наравно, његово конкретно

${ }^{266}$ Наравно, има још примера где је неки облик безбедносне културе или концепт безбедног живљења уведен у наставне планове и програме. У том погледу занимљиви су случајеви Русије и Турске, али и САД и неких држава Западне Европе. 
појмовно или концептуално присуство можда има краћу историју, али се елементи онога што данас обухвата теоријски оквир безбедносне културе могу пронаћи далеко у прошлости, где су поникли, пре свега, појам културе, а онда и безбедности.

Познато је да се теоријске идеје не стварају у сваком проучавању сасвим из почетка, већ се оне преузимају из других, сродних подручја проучавања, а затим примењују на нове или старе проблеме, који се интерпретирају из неког другог угла и постепено усавршавају. Из тог разлога смо на почетку овог поглавља и представили неке концепте, тражећи управо оно што је заједничко за њих и за концепт безбедносне културе.

Када је у питању инострана литература, термин „безбедносна култура“, као што смо већ приметили, први пут је поменут у Завршном извештају Међународне агенције за атомску енергију (IAEA, 1986) о нуклеарној катастрофи у Чернобилу. ${ }^{267}$ Заправо, овде је реч, према данашњим схватањима, о безбедности и култури заштите на раду, јер се односи на концепт safety culture (енглески термин), који се у српском језику може превести и као безбедносна култура. Иначе и у литератури са енглеског говорног подручја постоји извесна нејасноћа, јер се поједини извори позивају на термин „safetyкултура“, а други на термин „security-култура“, при чему оба наводе дефиницију из Извештаја Међународне агенције за атомску енергију, иако су се у међувремену та два концепта раздвојила и показала своје специфичности. Као што је већ назначено у делу који се бави теоријским појмовима, то су концепти који имају много тога заједничког (пре свега, када је у питању њихов организациони аспект), допуњавају се, али постоје и елементи који наглашавају неку специфичност својствену свакоме од њих појединачно.

Након Чернобиља су уследиле и остале катастрофе које су биле предмет детаљног јавног испитивања, а које су разоткриле значајну улогу организационих и друштвених фактора на ток и исход тих катастрофа. Термин

${ }^{267}$ Извештај број 75 INSAG-1, 1986. Термин „безбедносна култура“ још је потпуније објашњен у „Основним принципима безбедности нуклеарних електрана“, у оквиру серије упутстава No 75, INSAG-3, објављеним 1988. године. 
„безбедносна култура““ изложен је у неким од ових извештаја као објашњење како је комбинација управљачких, организационих и друштвених фактора допринела катастрофама. ${ }^{268}$ Давање високог приоритета безбедносним питањима IAEA је дефинисала као индикацију безбедносне културе (IAEA, 1986; INSAG, 1991).

Тако је IAEA (1988) дефинисала „безбедносну културу“ као „скуn карактеристика и ставова организачија и појединаща који установљавају да, као најважнији приоритет, највище пажне добијају (нуклеарна) безбедносна питања којима је то загарантовано юиховим великим значајем“. У међувремену је предложено још мноштво дефиниција, али је највише цитирана она коју је предложила британска Здравствена безбедносна комисија, према којој је „безбедносна култура производ индивидуалних и групних вредности, ставова, запажања, надлежности и модела понашања које одређују обавезивање, у истој мери као и стил и вештина здравствено-безбедносног менаимента једне организације“ (HSC, 1993).

Дакле, почетна замисао о „безбедносној култури“ везује се за безбедност и културу заштите на раду, у оквиру ширег спектра организација, укључујући и оне које обухватају јавну безбедност, безбедност јавног транспорта, као и нуклеарну индустрију. То су управо области и организације које су данас све чешће мете терористичких напада. ${ }^{269}$ Самим тим се пружа наговештај да будућа размишљања иду у правцу већих могућности развијања безбедносне културе која превазилази оквире safety-културе.

${ }^{268}$ Видети шире: Igor Khripunov and James Holmes, Nuclear security culture: The Case of Russia, Center for International Trade and Security, University of Georgia, December 2004.

${ }^{269}$ Главна претња од нуклеарног тероризма појављује се не толико услед могућности да владе тајно деле своје нуклеарно знање и материјал колико од сценарија не-државних актера незаконитог стицања таквих материја из лоше заштићених објеката. Штур надзор граница и недостатак заједничких стандарда нуклеарне безбедности међу земљама повећавају ризик од нуклеарне крађе, посебно у Русији и Пакистану. Из тог разлога је и важно радити на развоју и примени безбедносне културе која ће нагласити одговорност међу појединцима који су укључени у управљање и заштиту нуклеарних постројења и материјала на сваком ступњу организационе хијерархије. 
Од 11. септембра 2001. године промениле су се многе ствари на пољу безбедности, па тако и када су у питању различити ентитети и идентитети, као и њихова изложеност безбедносним и/или небезбедносним појавама и феноменима. Тако је и разлика између заштите на раду, људских ресурса и безбедности постала магловита и нејасна. Професионалци у области безбедности почели су да се сусрећу са већим бројем и разноврснијим претњама у свим доменима, па и на радном месту.

Поред планирања за традиционалне опасности на радноме месту, почели су да се суочавају са новим опасностима од пандемије, тероризма, е-бомбе и сајберкриминала. $^{270}$ Врсте претњи којима су сада изложене многе организације почињене су намерно, континуиране и безличне, за разлику од случајних, спорадичних и/или катализованих претњи у личним односима, који су раније преовладавали. Самим тим су бројни изазови планирања ефикасне заштите за запослене, клијенте и целу заједницу у таквом окружењу.

Наравно, разматрање развоја и теоријског утемељења појма безбедносна култура има више домена и димензија у којима се може сагле́дати и проучавати. Заправо, може се разматрати и према мерилу ширења истраживачког поља (националне) безбедности, које има своју хоризонталну и вертикалну димензију. У хоризонталном смислу подразумева ширење концепта безбедности од војне према политичкој, економској, социјеталној, безбедности животне средине, а у вертикалном - с једне стране, према међународној и

270 Традиционално су се, као што је познато, разматрала питања и развијали планови ванредних ситуација за типичне сценарије - од пожара, земљотреса, насиља на радноме месту, укључујући противимовински криминал. Данас се на основу порука од 11. септембра јавља потреба да се инкорпорирају најбоље праксе и постојеће политике и процедуре. Неопходно је правити планове и за доскора незамисливе ситуације, када се обликују комуникација, стратегија путовања, планови за евакуацију и безбедност техничких средстава и опреме. Корпорације морају бити спремне да се носе са питањима дискриминације мањина, сајбернападима, е-бомбама, могућим пандемијама, да се систематизује провера акредитива за посетиоце и слично; такође, да се планира и развија превенција криминала кроз специфично обликовање животне средине. 
глобалној безбедности и, с друге, раздвајањем безбедности државе (националне безбедности) од безбедности друштва и појединца.

Када је у питању домаћа литература, појам безбедносне културе је први пут дефинисан у Лексикону безбедности, где ју је Обрен Ђорђевић описао као део опште културе који обухвата „скуп сазнаға из области безбедности (основне вредности и тековине које су објекат напада и заштите, методи и облици, као и носиочи угрожавања) која чине појединце, средине и друштво способнијим да распознају методе, облике и радње угрожавања, као и носиоце тих делатности, без обзира где се и како испољавају“. ${ }^{271}$ Као термин споменут је, како смо видели, и раније, у делу који говори о концепту друштвене самозаштите, али није дефинисан.

Након тога, као што је такође већ наведено, Љубомир Стајић је покушао да преобликује и још јасније дефинише термин и представи га као „скуп усвојених ставова, знаға, вештина и правила из области безбедности, испољених као понашање и прочес, о потреби, начинима и средствима заштите личних, друштвених и међународних вредности од свих извора, облика и носилаца угрожавања, без обзира на место или време юиховог испољавања“. ${ }^{272}$

Као што можемо да приметимо, овде су поред знања, обухваћени и ставови и правила из области безбедности које је неопходно усвојити како бисмо се успешно супротставили изворима, облицима и носиоцима угрожавања и сачувале виталне вредности. Оно што примећујемо да недостаје дефиницији, то су културна знања и контекст у којем се одвијају нека безбедносна појава, а потом и понашање, као и могућност да се акцент стави на развој и добробит. Дакле, недостају елементи који упућују на подстицај и могућност да се друштво развија уз развијену безбедносну културу. Даља елаборација и анализа Стајићеве дефиниције открива и разлоге таквог третирања те проблематике, с обзиром на околност да је настајала у условима покушаја формирања нове наставне дисциплине у оквиру образовних институција почетком XXI века у Републици Србији и промовисања новог/старог концепта

\footnotetext{
${ }^{271}$ Обрен Ђорђевић, Лексикон безбедности, Партизанска књига, Београд, 1986, стр. 23.

272 Љубомир Стајић, Основи безбедности, Драганић, Београд, 2006.
} 
сведруштвеног укључивања и ангажовања према новим надолазећим безбедносним изазовима, ризицима и претњама. ${ }^{273}$

Заправо, примећује се да обе дефиниције стављају нагласак на знање и могућности које нам оно пружа да се лакше изборимо са опасностима и сачувамо вредности које су издвојене као важне. Онако како се ширило поље тумачења безбедности, али и појма културе, и развијали нови концепти који нуде другачија решења, на бројне проблеме савременог друштва, тако су и ове дефиниције показале извесну неиспуњеност захтева према новим погледима и новим идејама које могу заузети поље безбедносне културе. Наравно, не смемо заборавити да то како ћемо нешто дефинисати зависи и од тога како ћемо и у које сврхе употребити одређени појам или читав концепт и које потребе задовољити.

Тако и домаћи аутор Радомир Милашиновић у својим текстовима говори о безбедносној култури као о једном од најзначајнијих чинилаца превенције друштвених сукоба, како на глобалном, тако и на регионалним и националним плановима. $^{274}$ Такође је, посебно апострофирао безбедносну културу појединца, друштвених група и друштвених елита, као и потребу да се социјализују они садржаји који су неопходни за нормално функционисање друштва.

Спорадично се још неколико пута појавила у текстовима домаћих аутора, али без јасне намере да се дубље уђе у теоријско промишљање и анализу онога што тај појам све обухвата, како се конституисао и како би се могао даље

273 Као резултат одређених пројеката и програма објављене су и прве публикације из ове области у Републици Србији. Видети: Љ. Стајић, С. Мијалковић, С. Станаревић, Безбедносна култура, 2005; Љ. Стајић, С. Мијалковић, С. Станаревић, Безбедносна култура младих, Драганић, Београд, 2006; С. Станаревић, Ф. Ејдус (уредници), Појмовник безбедносне културе, Центар за цивилно-војне односе, Београд, 2009.

274 Радомир Милашиновић, „Безбедносна култура као фактор превенције друштвених конфликата“, Зборник радова, Факултет цивилне одбране, Универзитет у Београду, 2005, стр. 51-63; и Радомир Милашиновић и група аутора, Теорије конфликата, Факултет безбедности, Библиотека „Настава“, Београд, 2012, стр. 234-241. 
развијати. ${ }^{275}$ У свом тексту Желимир Кешетовић је нагласио да се безбедносна култура ослања, пре свега, на значење културе које подразумева развитак способности духа или тела који је резултат одговарајућег вежбања и васпитања. Сагласно томе, за појединца, групу или друштво који располажу развијеним вештинама и знањима која се односе на методе и облике угрожавања друштвених и личних вредности и могућности њихове заштите, а која су на одговарајући начин преношена и унапређивана, може се констатовати да поседују развијену безбедносну културу.

Од тренутка када се први пут појавио термин „безбедносна култура“ (независно од тога да ли је у питању домаћа или страна употреба) учесталост употребе тог израза знатно је порасла, пре свега у медијима, а онда и у литератури. Након извесног времена од појаве термина његова употреба је готово удвостручена. Овај процес подразумева и одвајање концепта од свог првобитног контекста и појаву нових значења и референци.

\subsection{1 Теоријски основи безбедносне културе}

\subsubsection{1 Хуманолошка перспектива}

Људи су одувек на два начина тражили сигурност задовољавајући потребу, а потом и интерес за безбедношћу: један је фаталистички верски модел по којем људи у потрази за древним легендама и обичајима усклађују своје понашање са Божјом вољом или природним правом, а други је научни модел човека над природом, тј. условљен проналаском уметности и алата, као и природом социјалне искључености и несигурности у одређеним оквирима.

Западна традиционална друштва са модерним променама у процесу науке постепено су заменила доминантну религију, тј. несигурност друштвених и

275 Видети текстове Далибора Кекића, „Култура безбедности у савременим схватањима безбедности“, Међународни проблеми, 2004, вол. 56, бр. 2-3, стр. 221-248; и Желимира Кешетовића, „Безбедносна култура у условима друштвених промена“, Безбедност, 6/95, Виша школа унутрашњих послова, Београд, 1995. 
природних фактора који се разилазе по разним питањима, проналажењем истине рационалном логиком која ће решити проблеме. Тако је, с једне стране, решавање проблема уз помоћ науке било прилика за нову буржоазију да пружи нове погледе и теорије сазнања, које су постале и основе за безбедност одређеног начина живота.

С друге стране, наука је била и разлог да се оствари раст у областима као што су унапређење људске контроле и могућности да се сачува и унапреди животна средина. На тај начин, људи су веровали да је кроз моћ разума и науке у потпуности могуће разумети и контролисати неизвесност природних и друштвених појава. Дакле, модерно друштво има апсолутно поверење у разум и науку, па на основу тога може бити у стању да задовољи захтеве људи за вредностима као што су сигурност и извесност.

Међутим, појавило се питање како да се то апсолутно веровање у науку и разум, претвори у нацрт оперативног система и институционални оквир, како би се достигла безбедност људи, тј. да њихов живот буде дугорочно стабилан и уредан, што је просветлило мислиоце и политичаре да размишљају о заједничким питањима, од којих је најважнија безбедност. Дакле, у питању је изградња снажне државе/нације и њеног уставног поретка да би се решио најважнији механизам неизвесности људског друштва. И ту се јавља већ познати начин размишљања Хобса, Русоа или Лока о утемељењу политичког легитимитета на уговору, што је основа на којој се организује држава.

Тек када је питање личне безбедности постало подједнако важно као и национална безбедност, савремени западни политиколози и политичари почели су да размишљају како институционални аранжмани кроз науку и разум ограничавају државну власт и штите индивидуална права. Узимајући у обзир поремећај међународне заједнице, с једне стране, и нацију-државу у заштити унутрашње безбедности друштва и слободе живота људи, као најважнију подршку, с друге стране, било је потребно да се достигне безбедност националне државе тако што ће постати одраз безбедности друштва и живота људи као премиса свих проблема. Ово представља епистемолошке основе савременог концепта безбедности, а посредно и концепта безбедносне културе. 
Зашто онда, рационално посматрајући ствари, људи никада не брину о националној држави, али имају апсолутно поверење у то да може дугорочно заштитити њихову безбедност? Ово се односи на западни свет, савремени концепт: безбедност државе - друштво - лична безбедност; дакле, обједињена три нивоа питања.

Од формирања новог западног концепта безбедности постигнуто је апсолутно владање људи над природом посредством рационалистичке мисли и науке, технологије промовисања људског прогреса, научног мишљења, учења, на основу апсолутног поверења нације-државе и владе да заштите безбедност друштва и безбедност грађана. Национална безбедност је као језгро савременог концепта безбедности, како је већ одавно познато, успостављена Вестфалским уговором, након консолидације и уз пратњу експанзије капитализма, који је тежио да постане светски популаран концепт.

Међутим, достигнућа индустријског друштва, домашаји цивилизације довели су до многих негативних последица, тако да ни сама наука ни рационализам нису могли да предвиде ризик од повећања неизвесности у све више глобализованом свету. Установљене да би заштитиле безбедност, националне државе се све више показују као непоуздане, неспособне да зауставе ерозију коју проузрокују спољне силе и унутрашњи сукоби идентитета. Заправо, слабљењем државе не могу да се остваре стабилност и заштита друштва, па она полако губи своју првобитну моћ да заштити живот људи.

Новонастала неизвесност је пољуљала националну безбедност као језгро мита модерног концепта безбедности. С друге стране, научни и технички изуми понекад су у супротности један са другима и такође пуни неизвесности, тако да су, када је у питању наука о животној средини, еколошке, економске и социјалне штете немерљиве и чине главни извор ризика. Дакле, за безбедност људи је неопходна наука, али се показало да наука у исто време изазива нове несигурности. Парадокс ове рефлексивне рационалности гласи: сви рационални напори да се реше проблеми довели су до нових проблема, а упоредо са растом националне власти и људског разума расте и ризик, па је све теже контролисати и прогнозирати у свим наукама, како би се избегле све 
врсте нежељених последица. Тако је савремени свет ушао у кризу, коју је предводило глобално друштво ризика.

Уследила је фаза у којој се све више изражавала непоузданост нације/државе, а такође и слабљење националног идентитета. Државне економске функције су пренете на светско тржиште, културне функције се враћају локалним заједницама, национални ентитети губе привилегован положај у политичком поретку, а од њих су многи остали без суверенитета, који више нема мобилишућу снагу. Критеријум за меру националних капацитета више није снага национализма, јер се, зарад политичког и друштвеног поретка и кохерентности државе, та иста држава и њени држављани приморавају да напусте осећај припадности и сигурности које су имали у значењу које им је дала националистичка идеологија, а које је сада у (не)милости слободног протока глобалног капитала.

Као последица неконтролисаног поремећаја конкуренције на тржишту јавља се све јача потреба да се заштите животна средина и људска права. Постепени губитак националног, економског и културног примата руководства државе доводи и до изласка изван стандардног осећаја националне државе, а самим тим и безбедности. Као што знамо, огромне промене су се збиле након 11. септембра. Ови догађаји у САД показали су како су многе земље у стању да обезбеде сигуран статус у међународној заједници, али не могу да заштите безбедност друштва у земљи и безбедност живота сопствених грађана.

Према западним стратезима и теоретичарима (предњаче они из САД), као главни безбедносни проблем идентификује се тероризам, тако да све државе доспевају у једну врсту непријатне ситуације: ако се користе високе технологије, што значи да прате и контролишу укупно функционисање друштва и живота људи, онда је кршење закона да захтевају од људи ограничења за разне слободе и права. Међутим, таква употреба технологије и рационалности, као одговор против сила тероризма, прожима све сфере друштва. Чак ни најмоћније државе нису у могућности да обезбеде апсолутну сопствену сигурност - државе, друштва и појединца, на свим нивоима - и 
војне, политичке, културне, економске, еколошке области доведу у безбедно стање.

Економска глобализација је учинила друштво мање заштићеним у националној држави, а овај губитак националне државе да заштити и контролише друштво пун је неизвесности, не само услед нестабилности глобалног тржишта капитала и тренутне природе информационе технологије, већ и због нагомилавања различитих фактора ризика за глобалну заједницу, што је довољно озбиљно да се изазове паника. Такође, у многим друштвима се и трагање за признањем јавља као циљ неких друштвених покрета, екстремног национализма и фундаментализма. У настојању да се обезбеде социјална стабилност и безбедност правног система долази до неефикасности у деловању државе, а јавне кризе угрожавају безбедност савременог западног друштва. Наравно, ти ломови, ризици и кризе нису заобишли ни свет изван онога који зовемо Запад.

Нација-држава показује смањену способност да заштити безбедност друштва, не може да кроз социјалну интеграцију и политичке интеграције одржи социјални поредак. Међутим, социјална сигурност актера није једини проблем и питање само једне или неколико културних група и друштвених организација, већ су и на глобалном нивоу то ризици и просветитељски осећај „кризе људи“. У ери глобализације несигурности, која изворно припада националној држави, и друштво, које је под двоструком заштитом људских безбедносних питања, сада мора да позове наднационалне организације и искаже забринутост. То уједно показује да облик државног система, акциони програми и идеологије, друштвени и структурни аранжмани имају различите нивое безбедносних питања.

Укратко, у ери глобализације, структура и функција националне државе не могу се одржати употребом војног насиља, а такође је нереалистично да очува своју безбедност кроз повољан статус у међународној заједници, док у земљи не може да одржи стабилну социјалну сигурност и друштвеног идентитета. Управо зато што губе двоструки слој заштите државе и друштва, сви појединци имају директан интерес за покушај да нађу решење за опстанак креирањем стратегије за разна безбедносна питања. У том смислу, утемељена на 
апсолутном поверењу у науку и рационалност, као језгро, национална безбедност не успева да се најбоље прилагођава новом концепту безбедности у модерној ери, па се јављају тенденције према новим концептима безбедности. Поред већ поменутих, у другом поглављу рада, на Западу и међу многим невладиним организацијама и научницима почела је да се развија људска безбедност као језгро новог безбедносног концепта.

Присталице и промотори овог концепта померили су фокус истраживања у пољу безбедности од националне безбедности и војне безбедности према претњи опстанку човечанства, укључујући нове претње и ризике, као што су тероризам, екстремни национализам, деградацију животне средине, природне непогоде, технолошки развојне ризике и слично. По њиховом мишљењу, главни део корпуса безбедности изузетно се променио: од државе продужен је на човечанство у целини, без обзира на националност, боју, расу и класну припадност, људи су предмет безбедности, а измењен је и ниво безбедности. Од макронивоа националних структура и војне опреме ниже до микронивоа појединаца. Услед недовољне теоријске заснованости и овај концепт као и решења која нуди за проблеме у области безбедности показао је извесне недостатке и подстакао научнике, истраживаче, радознале појединце да трагају даље.

И поред бројних оспоравања и набрајања недостатака које је држава испољила када је у питању њена способност да одржи ниво националне безбедности и, сходно томе, ниво безбедности друштва и појединца, показало се да је она и даље један од стубова безбедности с највише легитимационих механизама којима ће и даље на најбољи могући начин остваривати тај задатак. Оно што је ново и што треба да се уважи јесте прихватање присуства других актера у пољу безбедности, који имају своје интересе и своје капацитете да учествују у осмишљавању и постављању основних смерница и путоказа који ће определити развој и инструменте националне безбедносне политике.

Пренаглашеност војних аспеката националне безбедности током Хладног рата одвијала се на рачун историјских, психолошких, културних, организационих и политичких аспеката. Управо је техничка строгост и прецизност многих 
стратешких анализа постигнута по цену губитка додира са политичким варијацијама и променама, али стиче могућност да кроз друштвено-историјску и културну анализу, које су у основи хуманолошке перспективе, баци ново светло на питање националне безбедности.

Да би се то остварило, потребно је нагласити важност холистичког приступа овој проблематици, а у теоријско-методолошком погледу снажније ослањање на феноменолошке, херменеутичке и (де)конструктивистичке методе, као и већу заступљеност квалитативних истраживачких поступака у односу на квантитативне. Употреба људског разума и „разумске моћи сазнања“ губи на доминантности коју је првобитно поседовала, јер се све више показује да се рационализовано научно знање не може „преклопити“ са стварношћу независном од човека и његовог субјективног утицаја. А ти утицаји су у значајној мери условљени културом и њеном вредносном димензијом, често осмишљеном и конструисаном управо у ирационалној сфери, хтели ми то да признамо или не.

Када су покренута истраживања о култури и њеној улози у међународној безбедности, један од приступа се, као што смо раније већ видели, ослањао на објашњење понашања државе, при чему се култура користила да попуни празнине у објашњењу тога „како свет ради“, конструисањем теорија које су засноване на државном интересу и прерасподели моћи. Према овом тумачењу култура се сматрала променљивом која може утицати на понашање, али је ипак од секундарне важности за међународне систематске притиске.

Други приступ је културу видео као теоријски модел који може објаснити нека, ако не и сва стратешка понашања. Овај приступ се примењује на друге области знања, као што је политичка психологија, да би се формулисала теорија културе која се може проверити и која може допринети кумулативном програму истраживања. У овом смислу култура је независна променљива која објашњава политику безбедности, попут неореализма или неолибералног институционализма, или још и боље од ова два теоријска правца.

Трећи приступ је обухватио све оне који верују да аспекти људског понашања могу бити разумљиви само када се човек удуби у културу, при чему се 
игноришу разне „оповргнуте“ теорије. Неки антрополози и социолози сматрају да је култура састављена од комбинације дискурзивних и недискурзивних изражавања. Култура је према њима изузетно снажна, али је њен утицај на политику готово немогуће измерити.

\subsubsection{2 Природни и друштвени извори безбедносне културе}

У уводном делу смо видели како су се, када се први пут појавила идеја да култура може дефинисати стратешке исходе, а такође и касније у раду, од почетка Другог светског рата и након њега, развијала истраживања о улози културе у начину вођења рата, или начину изградње мира којима су приступале одређене државе или савези. Постепено су се развијали концепти политичке, а потом и стратешке културе, који су представљали основне теоријске премисе на којима се градио и даље гради и концепт безбедносне културе. У литератури су идентификовани различити извори (материјалне и идејне природе) који су допринели да се развија концепт стратешке културе, а (не)посредно можемо рећи - и концепт политичке и безбедносне културе, сваки на свој начин, уважавајући дате изворе. ${ }^{276}$

Географија, клима и природни ресурси кључни су елементи у стратешком размишљању вековима уназад, али настављају да врше утицај на стратеге, политичаре и актере безбедносних структура и у XXI веку, управо у контексту измене глобалне територије и ресурса̂. Историја и искуство су такође веома важни фактори које треба узети у обзир при настанку држава, као и стратешких (националних) културних идентитета од којих се састоје. У теорији међународних односа идентификовано је неколико типова држава у опсегу од слабих до снажних, колонијалних до постколонијалних, те премодерних, модерних и постмодерних. На тај начин је уочена могућност да се различите „врсте“ држава могу суочити са разноврсним стратешким проблемима, тешкоћама унутар граница државе, као и са различитим материјалним и идеацијским ресурсима у односу на које примењују јединствене одговоре.

${ }^{276}$ Darryl Howlett, „Strategic Culture: Reviewing Recent Literature“, Strategic Insights, Volume IV, 10, October 2005. 
За новостворене државе потешкоће настају код тек конституисаних нација које могу бити засноване на несигурности и из тог разлога тражити помоћ при обликовању идентитета стратешке или безбедносне културе. Супротно томе, запажамо државе са дужим постојањем, на основу чега се може захтевати узимање у обзир фактора који доприносе расту и паду великих моћи или цивилизација и прилагођавању њихових политика.

Други веома важан извор стратешке, политичке, а самим тим и безбедносне културе јесте природа државне политичке структуре и организација одбране, али и безбедности унутар државних граница. Неке земље су прихватиле да развијају широко распрострањени западни, либерално-демократски стил владавине, док друге нису. Неке су већ са зрелом и развијеном демократијом, док неке тек пролазе кроз демократску трансформацију на различитим стадијумима консолидације. Којом ће се брзином одвијати консолидација, често зависи и од односа снага племенских, религијских или етничких заједница, које су активне и често супротстављене стране унутар територијалних граница.

Слично томе, организација одбране, као и других сегмената безбедносних структура, има веома важну улогу и утицај на развој стратешке и безбедносне културе. У том смислу се говори о томе да ли је војска професионална или регрутована, да ли је полиција „сервис“ грађана или је у служби владајуће политичке структуре, какав је приступ раду обавештајно-безбедносних структура. Поред набројаних, овде се могу разматрати и војне доктрине, цивилно-војни односи, сарадња полиције са грађанима, демократска и цивилна контрола сектора безбедности, као и остале праксе које могу имати велики утицај на стратешку, политичку и безбедносну културу односно бити њихов саставни део.

Митови и симболи се такође узимају у обзир и представљају битан сегмент свих културалних груписања. И једни и други могу бити фактор стабилизације или дестабилизације у еволуцији идентитета стратешке, политичке и безбедносне културе. Помен мита може имати различито значење - од традиционалног разумевања као нечег „неоснованог или погрешног“ до 
савременог, које носи позитивну етичку и духовну димензију. Џон Калверт [John Calvert] је навео да се мит може односити на „групу уверења која изражавају основне, често несвесне или претпостављене политичке вредности друштва - укратко, као драматичан израз идеологије. Детаљи који се наводе у политичком миту могу бити истинити или погрешни; већина њих чини комбинацију истине и фикције на начине на које их је немогуће одвојити... Да би био ефективан, политички мит мора ангажовати не само разлог већ и уверење и веру. “277

Карен Армстронг [Karen Armstrong], у својој Краткој историји мита, наводи да су нам „потребни митови који ће нам помоћи да се поистоветимо са свим људским бићима, а не само са онима која припадају нашем етничком, националном или идеолошком племену. Потребни су нам митови који нам помажу да схватимо значај самилости, која се нашем прагматичном, рационалном свету сматра недовољно корисном, или делотворном... Потребни су нам митови који ће нам помоћи да земљу поново уважавамо као светињу, уместо да је само користимо као 'ресурс'. Тако нешто је пресудно, јер уколико не дође до неке врсте духовне револуције која ће бити у стању да се носи са нашом технолошком генијалношћу, ми нећемо моћи да спасемо нашу планету. ‘278

Симболи се такође наводе као социјални објекти који се више или мање разумеју и који обезбеђују оријентацију културалним заједницама са стабилним референтним тачкама за стратешко размишљање и деловање.

\footnotetext{
277 Бројни западни мислиоци су испитивали ирационалне и инспиративне снаге као идеолошке подлоге, укључујући Вилфреда Парета [Vilfredo Pareto], Карла Шмита [Carl Schmitt] и Жоржа Сорела [Georges Sorel], оца теорије политичког мита. Сорелова запажања о природи симболичких слика и њиховом односу према политичком деловању и даље су корисна у разумевању митске димензије идеологија. Политички мит може успешно означавати ирационалну спиралну опругу свих идеологија, „без обзира на површинске рационалности или привид здравог разума“. Видети шире: John Calvert, „The Mythic Foundations of Radical Islam“, Orbis, Foreign Policy Research Institute, Winter 2004.

${ }^{278}$ Карен Армстронг, Кратка историја мита, Геопоетика, Београд, 2005, стр. 106-107.
} 
О значају и улози симбола у животу једне заједнице, друштва и појединца већ смо довољно рекли раније.

Велики број аналитичара сматра кључне историјске текстове као веома важне изворе из којих се информишу актери одговарајућих стратешких акција и размишљања. Традиционална анализа мира и конфликта дуго је указивала на утицај оваквих текстова кроз историју и различите културалне околности. Тако се може пратити историјска путања писаних текстова од већ поменутих теоретичара и војних стратега Сун Цу Вуа, Тукидида, Клаузевица и других. У исто време, јавља се конкуренција међу бројним текстовима који остварују разнолик утицај на друштво.

Тако, на пример, за истраживање грчке стратешке културе био је идентификован осцилујући утицај две различите стратешке традиције. Са једне стране, постоје „традиционалисти“, који као своју духовну „храну“ наводе Ахилове подвиге, хероја Илијаде, и који свет виде као анархичну арену где је моћ ултимативна гаранција безбедности. Са друге стране, ту су „модернисти“, пратиоци Одисеја, хероја Одисеје, који, иако посматрају свет као анархично окружење, сматрају да је за Грчку најбоља стратегија прихватање мултилатералног кооперативног приступа миру и безбедности. ${ }^{279}$ Ово је, иначе, дуализам у стратешкој култури што одражава утицај дуговечних митова и легенди, који проналазе своју амплитуду осциловања и у модерном добу.

Безбедносна култура, која се може посматрати на различитим нивоима анализе, проналази своје митове и легенде и у другим димензијама и оквирима, као што су организације/корпорације, друштвене групе (етничке, верске и сличне) или појединац. Као веома значајни извори стратешке, политичке, а надасве и безбедносне културе могу се издвојити транснационалне или међународне норме, које је Александар Вент објаснио као „интерсубјективна уверења о социјалном и природном свету која дефинишу покретаче, њихову ситуацију

${ }^{279}$ Nikolaos Ladis, “Assessing Greek Strategic Thought and Practice: Insights from the Strategic Culture Approach", Unpublished Doctoral Dissertation, University of Southampton, UK, 2003; према: Darryl Howlett, „Strategic Culture: Reviewing Recent Literature“, Strategic Insights, Volume IV, 10, October 2005. 
као и могућности за предузимање акције“. ${ }^{280}$ Фарел [Theo Farrel] и Териф [Terry Terriff] сматрају да норме могу дефинисати „сврху и могућност војне употребе“ и обезбедити саветовање о питању употребе силе. ${ }^{281}$

Фарел такође наводи колико су међународне норме или војни професионализам утицали на националне политике и процес путем којег се све то дешава. Он такође сматра да међународне норме могу бити преведене у културални контекст земље помоћу процеса који подразумева притисак на циљну заједницу ради прихватања нових норми („политичка мобилизација“) или процесом вољног прихватања (,социјално учење“). Понекад долази до подударања међународних и националних норми уколико заузимају исти културални контекст, али се врло често и разилазе.

Када посматрамо димензију безбедносне културе која се артикулише унутар граница једне земље, онда се посматра и основ уређивања односа̂ у области безбедности чије су кључне одредбе изражене у највишим правним актима, пре свега уставу, а онда и другим законским и подзаконским актима. Понашање свих грађана и државних органа, као и делатност органа̂ безбедности усаглашени су са начелима и принципима садржаним у унутрашњем законодавству једне државе. То се јасно видело и код концепта друштвене самозаштите.

Технологија, и то нарочито информациона и комуникациона, такође се наводи као важан фактор који опредељује домете стратешке и безбедносне културе. Свет технологије представља и свет индивидуалног и групног ојачавања, који је глобалан и у смислу потенцијалне јединствености у погледу његове употребе, али и технологије двоструке употребе. Док су информационе и комуникационе технологије трансформисале друштво, такође су појединцима и групама омогућиле да комуницирају на неке нове начине и доведу до смањења дистанце.

\footnotetext{
${ }^{280}$ Alexander Wendt, "Constructing international politics", International Security, vol. 20, No. 1, 1995.

${ }^{281}$ Theo Farrel, Terry Terrif, The Sources of Military Change. Culture, Politics, Technology, Lynne Rienner Publishers, Colorado and London, 2002.
} 
Конструктивистички приступ безбедности деведесетих година двадесетог века, као што смо назначили у другом делу рада, довео је до обнављања интересовања за даљи развој теоријског рада о утицају културе на безбедност. Овај програм истраживања посебну пажњу је посветио формирању идентитета који настаје као резултат организационих процеса, историје, традиције и културе. Наиме, док су рационалисти третирали идентитете онако како су даิти, конструктивисти полазе од тога да су идентитети и интереси конституисани у друштвено-историјски изграђеним околностима.

Прелазак на разумевање безбедности као једне социјалне и политичке конструкције проширује могућност за формулисање питања која се односе нарочито на процесе промена, укључујући и то како непријатељи трансформишу свој однос у пријатељски, како се дефинишу претње и како је употреба силе конституисана. Конструктивисти се највише фокусирају на социјалну структуру на нивоу међународног система и улогу норми у међународној безбедности. Према Александру Венту, конструктивистички приступ је обухватио идентитете државе и њене интересе као „социјално конструисане на основу претходних знања“. ${ }^{282}$

Валери Хадсон [Valerie M. Hudson] из исте теоријске перспективе посматра културу као напредан систем заједничких значења који управља перцепцијама, комуникацијама и акцијама/деловањем. Сходно томе, Хадсонова сматра да у моменту акције култура обезбеђује елементе који дефинишу ситуацију, који откривају мотиве и који пружају снагу што води успеху. ${ }^{283}$

Пратећи линију конструктивистичке традиције, може се рећи да безбедносна култура дефинише безбедносни идентитет и зато обликује одређену приоритетну безбедност државе, групе или чак и појединца. Иако, у начелу, у једној држави не може бити више од једне безбедносне културе, која директно утиче на званични безбедносни дискурс државе, понекад се може евидентирати и нека друга коју производе друштво или одређене групе у друштву, али

\footnotetext{
${ }^{282}$ Alexander Wendt, "Constructing international politics", International Security, vol. 20, No. 1, 1995.

${ }^{283}$ Valerie M. Hudson, Culture \& Foreign Policy, Lynne Rienner, Boulder, CO, 1997.
} 
обично преовладава једна безбедносна култура и води службени (официјелни) безбедносни дискурс и понашање државе.

\subsubsection{3. Национални оквир безбедносне културе}

У литератури се тек последњих година појављују текстови који јасније дефинишу и који са приметно више аргумената говоре о националним безбедносним културама, стављајући их у контекст обрасца глобалног управљања. ${ }^{284}$ Међународни систем не представља демократску безбедносну заједницу нити испуњава неопходне услове да то убрзо постане. Регионални безбедносни подсистеми широко су рангирани - од елементарних система управљања (пацифички баланс моћи) до сложенијих облика управљања (ЕУ безбедносна заједница). У оквиру сваког регионалног подсистема који је заузврат под сенком великих сила укључених у овај савез, постоје варијације у политикама националне безбедности и приоритетним облицима управљања.

Националне безбедносне културе представљају објектив кроз који национални ауторитети преламају структуралне позиције државе у међународном систему, објашњавају субјективно разумевање објективних претњи националној безбедности, инструменте који ће се користити као одговор и придају предности или првенство унилатералним или мултилатералним акцијама. У том смислу се, према Кирхнеру [Emil J. Kirchner] и Сперлингу [James Sperling], издвајају елементи који одређују оквир националне безбедносне културе и на основу којих се она може анализирати. ${ }^{285}$ Када се говори о националном нивоу, дакле националној безбедности и безбедносној политици која се води у оквиру једне државе, уочавају се следећи елементи безбедносне културе:

- поглед на међународно окружење,

- национални идентитет,

\footnotetext{
${ }^{284}$ Видети: Emil J. Kirchner, James Sperling (eds), National Security Cultures - Patterns of global governance, Routledge, London and New York, 2010.

${ }^{285}$ Исто, стр. 11.
} 
- инструменталне склоности и

- предност или првенство у интеракцијама.

Први елемент се односи на питање да ли међународни мир почива на активној промоцији међународних правила и институција или на одвраћању и равнотежи моћи - дакле, какав је приступ рату, миру и безбедности. Кроз преглед различитих теоријских виђења концепта националне безбедности у претходним поглављима видели смо како су се развијали ти приступи унутар појединих држава, савеза или, генерално посматрајући, у оквиру међународних односа.

До краја Другог светског рата западне европске државе разумеле су да ратови и политика моћи представљају нешто лоше и неприхватљиво, дакле нешто што треба елиминисати кроз правни режим међународних односа. Од тада се безбедносне културе тих земаља развијају у духу сарадње, добре воље и принципа̂ поштовања основних права једних према другима. Све снажнија економија и безбедносни штит НАТО-а усмерили су даљи развој европске безбедносне културе, која је на крају почела да личи на познати „вечни мир“ Имануела Канта, доношењем изјава европских земаља да је „мир природна компонента државне политике“.

Ипак, на крају Другог светског рата они који су остали на другој страни гвоздене завесе научили су другачију лекцију: политика помирења, пацификације и немогућности да буду снажни доводи до катастрофалних последица за национални опстанак и зато је треба избегавати. За њих међународни односи функционишу по Хобсовој логици и ово схватање утиче на њихову безбедносну културу на дуже време.

Национални идентитет је важан и разматра се његова заснованост на принципима либералне демократије, поштовању владавине права, одбрани људских права и грађанских слобода те веровању у плурализам (у том смислу се и мултикултурализам може посматрати као политички концепт или као кључна компонента националног идентитета, што је, рецимо, случај Канаде). 
Међутим, национални идентитет се посматра и као статус једне нације у односу на међународну заједницу. То је, конкретније речено, степен идентификације једне суверене државе у савременом смислу са међународном заједницом. Такав степен идентификације може се посматрати у три категорије: у смислу позитивне идентификације, негативне идентификације и нулте идентификације. ${ }^{286}$ Позитивна идентификација значи да нација прихвата задовољавајући однос према суштини међународне заједнице и себе види као једног од чланова који активно учествује у свим дешавањима на међународној сцени. Негативна идентификација значи да нација заузима супротан став према међународној заједници, себе не види као члана те заједнице, изван „система“ је и не учествује у активностима за које сматра да ће пре имати негативан него позитиван ефект. Нулта идентификација значи да нација нити прихвата, а нити се противи међународној заједници, док своје активности одређује и уређује према потреби.

Наравно, изражена је и одређена врста присиле на идентификацију, где велика сила или савез утиче да се невољно прихвати идентификација са међународном заједницом. Ово се обично појављује у систему напајања хегемоније, у којој моћан утицај и притисак потичу од неке хегемонистичке државе. Други разлог који доводи до идентификације са међународном заједницом јесте интерес који има држава-нација и који је покреће на такву активност. Можемо говорити и о идеационој идентификацији, по којој се држава интегрише у међународну заједницу или неку интеграцију у оквиру те заједнице на основу идентитета, културе, норме и других фактора. Овде не постоји принуда спољашње силе, нити интерес, а то је, према Александру Венту, потпуна интернационализација међународног друштвеног система и норми. ${ }^{287}$

Инструменталне склоности се односе на став државе о томе да ли при доношењу неких одлука и поступака на међународној сцени користи привилегију меке или тврде моћи; а, такође, о томе колико је насиље

\footnotetext{
${ }^{286}$ www.irchina.org

${ }^{287}$ Alexander Wendt, "Constructing international politics", International Security, vol. 20, No. 1, 1995.
} 
прихватљив начин да се тражи извршење политичке промене било изнутра било споља, или се опредељују за решавање спорова мирним путем, применом ефикасних и принципијелних компромиса - дакле, да ли постоји тенденција да се користе више војна или више цивилна/мирољубива средства.

На крају, предности или давање првенства у интеракцијама подразумевају могућност да се делује мултилатерално у оквиру глобалних или регионалних међународних организација, или више билатерално са земљама из региона, чак и са могућношћу да се буде готово изолован (пример Северне Кореје) или неутралан.

Уважавајући све претходно речено, можемо констатовати да се безбедносна култура односи на промену безбедносне агенде и алтернативну перспективу националне безбедности која се развија крајем XX века. Све то се дешава у тренутку када је почело да се тврди како су културни елементи глобалног или унутрашњег окружења држава одлучујући у објашњавању националних безбедносних интереса, политика и понашања.

Иако је компликовано дефинисати прецизно који су ово елементи (неке смо већ навели), они могу да варирају од једног стања до другог. Као што смо видели, најчешће су у вези са историјским искуством у области безбедности, посебно оним најдраматичнијим ставовима према неким домаћим и међународним праксама, нормама и вредностима. С тим у вези Харалд Милер [Harald Müller] дефинише безбедносну културу као „скуп вредности, норми, правила и пракси које се односе на безбедност, који утичу на мишьење и деловање у области безбедности одређене државе, посебно понекад кроз појединачне обрасие“. 288

Када је у питању развијање и примена концепта безбедносне културе, као и његова институционална имплементација у одређене референтне оквире, можемо говорити о три домена. Први домен је већ поменуто поље деловања државе и безбедносне политике коју спроводи у пракси, посебно имајући у виду национални и међународни контекст. Држава је та која развија ову политику око идентификовања претњи (спољних и унутрашњих), као и

${ }^{288}$ H. Müller, „Security cooperation“, in: W. Carlsnaes, T. Risse, B. A. Simmons, eds., Handbook of International Relations, Sage Publications, London, 2002, p. 381. 
предвиђања одговора на те претње примењујући различите инструменте (мере и активности).

Такође, држава има обавезу да пружи конкретан израз те политике у националном законодавству и прописима, постављању кадрова и утврђивању надзорних овлашћења у погледу безбедности, утврђивања финансијских pecypса и сличних аспеката. Да би се обезбедила довољна заштита од процењених ризика и претњи, на пример, неке информације не смеју да слободно циркулишу у јавности, јер се могу користити у злонамерне сврхе. У том смислу, а с обзиром на поделу одговорности, државе прописују законска и подзаконска решења која регулишу област тајности података, као и опште принципе за одобравање приступа објектима и информацијама који су од значаја за националну безбедност.

Национална безбедност интегрише готово све аспекте друштвеног живота, а њен институционални оквир артикулише се и кроз домен рада организација у привредним и другим системима, тако да се други домен развијања и имплементације безбедносне културе може разматрати кроз њен организациони аспект, према којем свака организација, ослањајући се на политику државе, формира у процесу рада организациону културу засновану на елементима националне и безбедносне културе. У том процесу она спроводи и развија сопствену безбедносну културу, доприносећи на једном вишем нивоу и изградњи и развоју националне безбедности. О томе ће бити више речи касније у тексту.

Трећи домен се односи на став који усвајају различити појединци на свим нивоима за спровођење политике која промовише безбедносну културу у оквиру структуре у којој послује, живи и ради, као и могућност да је угради у своје свакодневне активности. Најважније је уочити да сви домени и димензије безбедносне културе морају међусобно сарађивати и бити упућени једни према другима, јер само у том случају имају смисла примена овог концепта и позитивне праксе које ће из ње произаћи. 


\subsection{2 Обележја концепта безбедносне културе}

Обележја концепта безбедносне културе неопходно је подробно утврдити и објаснити, јер представљају посебан и нов квалитет стварности у којој су два, условно речено, независна концепта пронашла пут да изграде један нови, са потенцијалом да искажу такву друштвену моћ којом ће засигурно омогућити и изградњу снажне националне безбедности. На основу свега што је до сада изложено о култури, потом и безбедности и, коначно, резултата до којих смо дошли разматрајући досадашњу анализу и тумачење појма, а потом и концепта безбедносне културе, можемо издвојити његова обележја пратећи и даље хуманолошко-културолошку перспективу.

\subsubsection{1 Синтетичка обележја}

Прихватајући једноставно објашњење синтезе као процеса комбиновања одвојених компоненти или елемената у једну целину, два елемента - у нашем случају култура и безбедност - граде однос, који поседује посебан квалитет. При томе је наш циљ био да откријемо зашто је тај однос важан. Синтеза је прилика да се створи ново знање из већ постојећих знања, односно да се комбинују или синтетизују из других истраживања, информације у ново истраживање и да се самим тим развије аргумент или јединствен поглед на тему. Дакле, у нашем случају синтезу посматрамо као могућност повезивања корпуса знања о култури и корпуса знања о безбедности у нову форму знања која се манифестује кроз концепт безбедносне културе.

Поред знања, што представља сазнајни елемент културе и безбедности, који се повезују или синтетизују, можемо посматрати и анализирати инструменталну димензију, која се огледа у средствима помоћу којих људи решавају своје проблеме, задовољавају своје потребе и истовремено се оспособљавају да се суоче са новим проблемима и да изађу у сусрет новим потребама. Оног тренутка када се у пољу безбедности детектује нови проблем, култура ће осмислити и произвести сврсисходан одговор на тај проблем и обезбедити 
адекватне инструменте које ће безбедносне структуре употребити и „савладати“ проблем.

Кроз процес синтезе пролази и нормативни аспект културе и безбедности, који сачињавају:

a) елементи помоћу којих се дефинишу актуелне тенденције понашања и друштвени захтеви у односу на индивидуе и друштвене групе (традиционалне навике и обичаји, друштвена правила и норме, вредности);

б) елементи помоћу којих се дефинишу тенденције као могућности (вредности као идеали) и формулишу визије (религија, филозофија, друштвене науке итд).

Синтетичка обележја подразумевају да се према културалним и безбедносним чиниоцима може поступати као према варијаблама унутар јединствених система анализе. То не подразумева само усклађивање терминологија или ковање нових, као ни наметање једног скупа категорија целој области. Заправо је више реч о интегрисању различитих типова теорија и појмова, тако да се могу формулисати смислене тврдње које обухватају резултате изоловане у одвојеним областима проучавања.

Систематском комбинацијом иначе различитих елемената (културе и безбедности) у форму једне кохерентне целине или обликоване потпуно нове појаве добили смо један нов „производ“ који даје потпунију истину којој свакако сви теже. Такође, синтезом добијамо једну вишу форму узајамности, као и потребу да се то прожимање операционализује у пракси институција и животу уопште.

\subsubsection{2 Трансферна обележја}

Иманентно својство сваког делатног људског бића које можемо означити атрибутом „културни“, макар и да је реч о најрудиментарнијим формама, јесте трансцендирање (трансфер) постојећег и стварање нечег новог што на 
сврсисходнији начин задовољава одређену људску потребу или решава неко егзистенцијално питање.

Уз упознавање културних посебности сопствене националне заједнице, пожељно је да се та знања употпуне знањима о другим националним заједницама и уједно усмеравају на разумевање и поштовање других народа, на прихватање разлика произашлих из утицаја другачије средине и на усвајање и поштовање основних људских права и слобода. Тиме се ствара основа за трансфер културног обрасца као друштвеног ресурса развоја путем гранања образовања у правцу безбедносне културе, организационе, као и професионалне културе рада и стваралаштва. На тим основима може да се гради и идентитет појединца или друштвене групе као аутентичан темељ за обликовање и развијање људских и свих других ресурса једне земље. Комуникациона, али и кумулативна функција културе можда су и најважније у овом процесу, јер представљају димензије које помажу реализацији преноса остварених достигнућа из једне у другу социо-културну средину.

Да бисмо објаснили трансферно обележје концепта безбедносне културе морамо узети у обзир различите нивое и димензије у којима се трансфер одвија, тако да запажамо пренос одређених функција у оквиру културе, пренос категорија и теоријских конструкција из једног концепта у други, пренос знања, пренос значења, пренос референтних објеката и субјеката безбедности из једног поља анализе у друго, пренос претњи, пренос методологија и истраживачких поступака и томе слично. Коначно, можемо и јасније дефинисати који су то све трансфери могући, а које смо пратили и кроз овај рад:

- трансфер развојних могућности човека из антрополошко-природног у хумано-друштвено стање, посредством интереса безбедности као антрополошког својства људског бића и као регулативног инструмента уређености друштвеног стања;

- трансфер природних својстава човека (оличених у слободи и суверенитету) посредством културе у друштвени живот; 
- трансфер потребе за безбедношћу у интерес безбедности, што уважава културно-историјску суштину настанка ентитета који остварује тај интерес (нација) и који треба да обухвати пожељан начин живота и његово неометано испуњавање богатством садржаја;

- трансфер традиција и вредности из једног историјског социокултурног амбијента у други;

- трансфер знања из сфере културе у сферу безбедности, и обратно, као и знања из сфере рационално̄г у сферу ирационално̄г, и обратно;

- трансфер концепта идентитета из поља културе у поље безбедности и трансфер у оквиру самог идентитета и његовог конституисања или реконституисања;

- трансфер функције опстанка, коју је култура првобитно имала, у функцију добробити и развоја;

- трансфер безбедносних ентитета - од државе/нације у безбедност друштвене групе и појединца, и обратно;

- трансфер претњи из поља војне димензије у друга, не-војна поља;

- трансфер активности и надлежности у оквиру безбедносног ентитета (нација), који укључује индивидуални, социјетални и државни аспект безбедности;

- трансфер институција из једне форме у другу и трансфер активности у оквиру рада и надлежности институција;

- трансфер националне културе у националну безбедност;

- трансфер националне културе у безбедносну културу;

- трансфер националне безбедности у безбедносну културу;

- трансфер методологија и истраживачких поступака у новом сагле́дању друштвених односа у сфери безбедности. 


\subsubsection{3 Развојна обележја}

Како смо у претходним поглављима могли да приметимо, култура (као ни безбедност) није статична категорија, већ поседује одређену динамику и импулс који воде промени. Реч је о развојној, односно стваралачкој димензији културе. Развојност културе је динамичнија од развојности која је својствена друштвеном поретку. Развој друштва може бити спутан непосредним и ограниченим циљевима. Међутим, развојност културе има способност да искорачи из тих оквира. Тај развојни континуитет је могућ управо због једног битног својства културе, које најчешће зовемо кумулативним, а чија је функција „да очува оно што већ постоји као резултат друштвеног и културног живота“.

Развој са становишта културе и природе и, са друге стране, безбедности ставља људе у са̂м центар разумевања и обликовања развојних обележја концепта безбедносне културе. Наиме, на тај начин се добија свеобухватност (не редукује се само на материјалне параметре, већ уважава и духовне), динамичност (обухвата развој нових потреба и жеља), отвореност (успоставља везу са спољним светом) и одрживост (поштује захтеве природе, али и природе човека). Ово обележје се заснива на култури која настоји да избегне изолационизам, романтизам, културни релативизам, културни фундаментализам и слична застрањивања, јер се права култура стално преобликује и обнавља. Са друге стране се заснива на безбедности, која добија нове форме и начине испољавања, што је, опет, условљено новим формама и начинима испољавања небезбедности као њене супротности и као подстицаја да се новим, развијеним средствима и програмима адекватно одговори на њих.

Промене у пољу безбедности које су се одиграле последњих деценија могу се третирати као развојне трансформације, јер су прошириле и унапредиле размишљања о безбедности. Па тако, налазимо размишљања која подразумевају не само схватање безбедности као одсуство егзистенцијалних претњи држави, већ и увођење нових предмета безбедности, као што су: друштвене, етничке, верске или друге културне мањине (социјетална/друштвена безбедност), појединци са њиховим потребама (људска 
безбедност) или читаво човечанство (глобална или светска безбедност). Дакле, нови носиоци безбедносних потреба у истој су равни и са једнаким правима као и држава.

Затим, поред физичко-политичке димензије безбедности територијалног ентитета у времену сложених међузависности, јављају се и нови аспекти у вези са безбедношћу људских живота, као што су: доступност економских ресурса, изграђеност и стабилност институција и могућности да обезбеди адекватан ниво заштите (економска сигурност), интегритет система да понуди информације о процесу од којих зависи модерно друштво (безбедност информација) и природна средина, као основа за сав живот, али и добављач ресурса на којима се развијају друштва и државе (еколошка безбедност).

Развојна обележја безбедносне културе подразумевају и нове начине промишљања и дискусије на тему изналажења нових националних стратегија и програма који ће правовремено и ефикасно одговорити на безбедносне изазове, ризике и претње, те оспособити друштво за живот у свету који се константно мења. У том смислу, и развој концепта безбедносне културе треба да иде у правцу стварања услова̂ за заједнички живот, развијања способности кључних политичких и других државних актера за решавање проблема из сфере безбедности, промовисања и развијања толеранције на свим нивоима живота и рада у једном друштву, разумевања и уважавања других и другачијих, разумевања разлога̂ зашто се свет мења, развоја солидарности и адаптације и слично.

\section{3 Безбедносна култура и процеси у свету}

Када се изађе из оквира националне безбедности, па самим тим и националне безбедносне културе, може се уочити да идеја о томе како култура или културални контекст дефинише или условљава одређене активности које се испољавају у виду понашања, начина доношења одлука, преговарања, развијања дипломатских средстава и слично прожима и све друге важне актере 
(осим државе) који постоје на међународној сцени и који ступају у одређене односе. Циљ тих активности може бити могућност да се унапреди и развије положај једне земље и њени капацитети, да се унапреди положај тих других актера, да у сваком погледу обезбеде просперитет, добробит и стабилност, а циљ може бити и да се ојача и искаже спремност за претње које се очекују у блиској будућности. Бројни процеси сарадње или сукобљавања одувек се одвијају и део су билатералних, регионалних, међународних и глобалних процеса и односа који се периодично граде или разграђују између држава, савеза или заједница.

\subsection{1 Регионални/билатерални односи}

Баш као што за националне државе Андерсон оцењује да су „замишљене заједнице“, још и више се то може рећи за регионе (неке више, а неке мање). До сада недовољно истражена димензија процеса „замишљања региона“ јесте изградња регионалне безбедносне културе. Постоје динамички артефакти (предмети) људске праксе који се стално развијају у контексту локалних, регионалних и глобалних нормативних промена. У расправу о регионалној безбедносној култури могу се укључити многи фактори који потичу из различитих нивоа анализе - тако, на пример: светска политичка култура, глобални дискурс о људској безбедности, суверена одговорност, добро управљање, регионалне политичке динамике и идентитети, унутардржавни режими, друштвени притисци и слични чиниоци.

Узајамни утицај ових променљивих допринео је упадљиво различитим безбедносним културама у разним регионима у свету, и то од (пре)интервенционистичких режима који су инкорпорирали глобалне норме у њихове регионалне безбедносне архитектуре до инертнијих аранжмана, који настављају да се придржавају класичних правила међународних игара. 
Све веће интересовање и фокус на безбедносној сарадњи на регионалном нивоу условљено је с најмање три повезане реалности и развоја. ${ }^{289}$ Прво, природа многих савремених безбедносних изазова креће се у оквиру регионалног простора (транснационалне болести, криминалне активности и промене у животној средини). Друго, УН и Савет безбедности негују праксу усвајања флексибилних и све разноврснијих тумачења тога шта представља претњу међународном миру и безбедности, што је резултовало високим темпом мировних операција и посредничких напора, што је заузврат указало на потребу УН да развије партнерство са различитим регионалним и другим институцијама. Треће, регионални аранжмани су постали много активнији у решавању безбедносних питања, иако не увек у светлу Поглавља VIII Повеље $\mathrm{yH}^{290}$

Више аутора се бавило упоредном анализом регионалних безбедносних култура, као што је случај са ЕУ или Афричком унијом и њиховом безбедносном културом. Представљајући их као студије случаја, илустровали су више повратних информација о вези између глобалних норми и регионалне безбедносне архитектуре. У литератури је сугерисано да регионални актери нити прихватају аутоматски глобалне норме нити их одбацују, али их прилагођавају локалним околностима тако што их „орезују“, односно мењају их како би више одговарале локалном контексту. ${ }^{291}$ Овај процес „орезивања“

289 Jürgen Haacke, Paul D. Williams, Comparing Regional Arrangements: The Significance of Security Cultures, Conference Turin, 12-15 September 2007. Видети: http:/turin.sgir.eu/uploads/ Williams-security_cultures\%20SGIR\%20paper\%20Sept\%202007.pdf

${ }^{290}$ Релевантни напори НАТО, ЕУ, Афричке уније (AU), Економске заједнице западноафричких држава (ECOWAS), Шангајска организација са сарадњу (SCO), Удружење југоисточне Азије (ASEAN) управо то и илуструју. Видети: Moore, Rebecca R., NATO's New Mission, Westport, CT Praeger; Howorth, Jolyon (2007), Security and Defence Policy in the European Union, Basingstoke: Palgrave; Adebajo, Adekeye (2004), "Pax West Africana? Regional Security Mechanisms", in: Adekeye Adebajo and Ishmail Rashid (eds.), West Africa's Security Challenges, pp. 291-318, Boulder, CO: Lynne Rienner; Caballero-Antony (2005), Regional Security in Southeast Asia, Singapore: ISEAS.

291 Amitav Acharya, „How Ideas Spread: Whose Norms Matter? Norm Localization and Institutional Change in Asian Regionalism“, International Organization, 58(2), 2004, 239-275. 
може се пратити кроз пример концепта Одговорности за заштиту (R2P), која је добила различите приступе у ЕУ и АУ (Афричка унија). R2P тако наставља да буде веома контроверзан концепт, чија је магловитост омогућила регионалним актерима да приложе прилично различита значења и учине их подударним са њиховим политичким програмима.

Чак и летимичан поглед на литературу открива да је истраживање регионалних безбедносних култура и даље у стању повоја. Концепт се још није етаблирао као аналитичко средство, иако је у последњих неколико година дошло до таласа расправа у публикацијама о тој теми.

Регионалне иницијативе у циљу успостављања функционалне интеграције, као и олакшавање поверења, комуникације и сарадње између народа и земаља, веома су важни за безбедност у региону и ширем окружењу. Такође је важно да се утврди које су иницијативе и процеси неопходни за анализу капацитета и квалитета безбедносне културе која се одсликава у њима. Процеси попут својевремених разговора КЕБС-а у Стокхолму, на пример, створили су веће поверење између држава и оправдавају многе умесне предлоге који су настали у међувремену. ${ }^{292}$ Али такви процеси треба да се прошире и примене и на регионе ван Европе, и да уложе напор да се развије политика која на крају може допрети даље од уских националних покушаја који гарантују безбедност. Европа има посебно важну улогу у ревитализацији нашег разумевања културе, управо зато што је Европа, са својом великом разноврсношћу народа, језика и историје, простор где је други увек у односу према ближњем и где се свако од њих стално позива да учи од свих осталих.

\footnotetext{
${ }^{292}$ Конструкција постојећег Европског безбедносног споразума, који је закључен 1972. године, када је донета одлука да се одржи Конференција у Хелсинкију на тему европске безбедности и сарадње, први је случај регионалног партнерства за безбедност у међународној политици и, до сада, једини прави случај регионалног партнерства за безбедност. Ово партнерство је заправо сазрело '90-их година, стварањем и/или интеграцијом мултилатералних механизама и организација као што су НАТО (источни пројектни механизам - Партнерство за мир), канцеларије и механизми ОЕБС-а, Политика безбедности и одбране Европске уније и Европске снаге за брзе интервенције (ERRF), Програми економске сарадње у склопу ЕУ, као и политика ширења.
} 
Потреба да се размотре перспективе регионалне сарадње потекла је од научника који сматрају да се регионална сарадња јавља у модерном свету у моменту када владе сматрају да је потребно преговарати о сарадњи и решавању проблема који су заједнички земљама у одређеној географској области. Ова интерпретација се умногоме ослања на увид да непоштовање културних дистанци и институционалних разлика, као и глобалних трендова, могу имати опасне ефекте на државе одређене области на различитим пољима. То могу бити поље загађености животне средине, поље демографије и, с тим у вези, питање миграција и јавне безбедности те проблеми организованог криминала и илегалне трговине.

Имајући у виду да географска близина учвршћује интеракцију између модерних друштава и држава, реакција једне државе, као и уздржавање од реакције код пограничних проблема, директно утиче на суседне земље. Из овог разлога, земље се заузимају за сарадњу и политику координације са владама суседних земаља како би обезбедиле стабилност, личну безбедност људима, економски раст друштву, а друштвеним групама културну заштиту. Регионални аналитичари се позивају да своју пажњу усмере на географске области - као што је, на пример, регион Медитерана - којима недостају културне и институционалне сличности. ${ }^{293}$

До сада су аналитичари игнорисали ове области као подручја сарадње, због ниског нивоа повезаности и мале сличности у вредностима и слабе идентификације са групом земаља учесница. Упркос томе, интеракције између држава и друштава са нехомогеним регијама бројчано расту. Пројекте сарадње подржавају владе регија, иако не постоје значајне сличности у кључним атрибутима, типа Источна Азија - Пацифик, Централна Азија и ЕвроМедитеран.

У складу са тим, може се закључити да се земље ових региона које немају традицију у доношењу заједничких одлука у решавању заједничких проблема све више приближавају земљама које су у прошлости стварале политичке и

${ }^{293}$ Fulvio Attina, The Building of Regional Security Partnership and the Security Culture Divide in the Mediterranean Region, Institute of European Studies, University of California, Berkeley, 2004. 
мировне савезе на основу формираних тесних социјалних веза заснованих на конзистентној сличности институција и вредности.

\subsection{2 Међународни односи}

Од тренутка када су настале прве државе, па све до данашњих дана, оне су ступале и ступају у међусобне односе који су мењали карактер и садржај током времена, али су увек имала циљ да сачувају што бољу позицију у међународном систему држава. На почетку стварања тих односа преовладали су конфликтни модели понашања, али се временом развио и кооперативни модел, који обухвата одређене ограничене облике сарадње који за циљ имају очување националне безбедности на међународном плану. Међународни систем држава се није градио да би се заштитиле искључиво вредности појединачних држава, већ је у условима повећане међузависности држава одражавао и шире вредности, које превазилазе националне оквире.

Безбедносна култура, посматрана у оквирима међународних односа, уважава ову чињеницу обезбеђивања равноправности, независности, самосталности и слободног развоја држава у међународном окружењу, али исто тако укључује и могућност опредељења чланица међународног система за одговарајуће вредности у међународним односима и релацијама унутар држава.

Иако може да звучи превише утопистички, али тешко да је неко могао помислити пре 50 година да ће од 1992. Европа бити уједињена, са заједничким тржиштем и апсолутно порозним границама. Еволуција ЕЕЗ, дакле, представља процес који лежи у срцу алтернативних дефиниција безбедности, на пример: функционалне интеграције, политичке сарадње, размене политичке моћи о кључним економским и социјалним политикама, развој институционалних механизама за ненасилно изражавање жалби и остваривање уздржаности и реципроцитета међу државама.

Иако можда постоје јединствене карактеристике подстицања европске интеграције, на делу су и неки основни еколошки, економски и безбедносни императиви који леже у основи нове доктрине за заједничку безбедност. Они 
приморавају државе да постану отвореније и пропусне, и такође почињу да изазивају непроменљивост националног суверенитета на исти начин на који су топови (и економски фактори) довели до краја феудализма. У том правцу се развија и безбедносна култура, подижући ниво свести свих актера на међународној сцени о неопходности и значају усаглашавања око одређених вредности, интереса и одређивање приоритета у вези с тим питањем.

\subsection{3 Глобални односи}

Глобализација је сложен процес који се не може разумети без истовременог разумевања збивања у међународном политичком и економском поретку који је наступио након Другог светског рата. То је процес са карактеристикама повећане интеракције, комуникације, међузависности, које су настале управо као резултат поменутих економских, политичких, али исто тако и културних промена које су обележиле другу половину XX века.

Процеси све интензивнијег економског и политичког повезивања, који су додатно оснажени филозофским визијама космополитског права и демократије, нужно су довели до релативизације нације-државе и националног суверенитета, али су такође (не)очекивано на површину избацили питање културе. У стручној литератури, као што смо и видели у претходним излагањима, аутори који се баве питањем геополитичких и стратешких промена крајем XX века све чешће експлоатишу појам културе као зависне или независне варијабле. Посебан значај добијају и појмови културног, религијског, националног и цивилизацијског идентитета.

Процес глобалног повезивања нарочито је утицао на народе, државе, културе, који реагују на различит начин - одбацују их, или делимично прихватају, све у зависности од врсте утицаја, као и од унутрашњих односа у којима се одвија рецепција спољашњих културних елемената.

Специфична безбедносна култура представља атрибут и укупног међународног и/или глобалног система, тако што и сви политички лидери света деле заједничко мишљење у погледу искуства и вере у безбедност, стабилност и 
мир. Међународно право, Организација уједињених нација и светске конференције за контролу наоружања и решавање сукоба оличавају институције за изграђивање безбедносне културе на глобалном нивоу. Националне и интернационалне дипломатске службе, академска удружења која се баве војним доктринама и експерти за решавање сукоба, политички лидери сви они су актери који раде на формирању и дифузији безбедносне културе широм света.

Такође, треба подсетити да се националне безбедносне културе и безбедносне културе региона преплићу и мењају током времена под утицајем институција и чинилаца глобалне безбедносне културе и дифузије нових идеја, пракси и искустава. Неке особености безбедносне културе појединачних региона могу позитивно оценити лидери других региона, али их могу и увести у те друге регионе као погодан модел, баш као што и владе примећују да их муче исти безбедносни проблеми. Тако се безбедносни механизми из једне области тестирају у другој како би се утврдило да ли имају позитиван ефект и да ли се као такви могу даље примењивати.

Међутим, један од главних проблема у вези размишљања на глобалном нивоу чини тешкоћа успостављања јасне концепције глобалне границе. Да ли је то нешто што је дефинисано у супротности са народима/нацијама или је у сагласности са њима? Насупрот физичким границама, које су углавном видљиве, културне и идејне границе знатно су сложеније и чини их мноштво различитих култура које постоје у свету као целини.

Постоје две реалности када се разматра питање граница - једна је да је тенденција људских заједница да афирмишу свој идентитет кроз успостављање границе између себе и других, а друга је чињеница да су границе одувек биле извор сукоба и доносиле лоше ствари људима и њиховим заједницама. Дакле, док су границе суштинско средство утврђивања разлике између појединих држава, оне такође представљају препреку за људске солидарности и често деле људе који би иначе били у стању да се слободно мешају и размењују идеје, искуство и заједничке погледе на стварност. Уколико оне генеришу етничке, језичке и културне конфликте, постају извор нестабилности. 
Тако можемо рећи да су пропустљивост, прилагодљивост и доступност националних граница критични фактори у еволуцији глобалне безбедности заједнице. Такав режим безбедности ће захтевати националне јединице које треба да буду довољно велике да омогуће ефикасну администрацију јавних добара, али треба да буду и довољно мале да би потпуно уважиле испољавање језичких, културних и етничких разлика. То такође захтева релативно слободно кретање људи преко граница, као што се десило у Европи током протеклих неколико година. Наравно, то неће бити увек поштовано од стране оних који су за ригидно поштовање националних територијалности и ускраћивање приступа онима који желе да се преселе.

С друге стране, отварање граница за слободан проток радне снаге, средстава и идеја представља своје посебне проблеме у погледу одржавања идентитета и привилегија. Дакле, неопходно је много напора како би се утврдили специфични начини за превазилажење уских националних просторних слика и промовисали економски и друштвено-политички процеси који ће помоћи генерисању развоја глобалне грађанске културе и безбедности.

Праћење ових процеса мора бити у духу реактивирања глобалне визије за увећање хоризонта за народе и креаторе политике. Управо је у оквиру УН под покровитељством симпозијума о глобалној безбедности за двадесет први век, на пример, било покушаја да се комбинује смањено ривалство Исток-Запад са све израженијим једнакостима између Севера и Југа и признавање различитих психолошких и духовних димензија безбедности. ${ }^{294}$ У ранијим излагањима у оквиру Уједињених нација такође је указано да ће се знатна пажња посветити неопходности подвргавања трансформације свести.

„Како бисмо се изборили са миром, дакле, морамо проћи паралелну трансформацију, од племенске преко националне свести до глобалне свести. Морамо активирати осећај припадности целе људске заједнице да су грађани целе планете и морамо стећи перспективу из које видите Земљу и целу људску заједницу као целину... У овом историјском тренутку потребан нам је не само

294 Symposium on Global Security for the Twenty-first Century, December 1986, Florence, Italy, Published 1987, by United Nations in New York. 
симбол мира, већ и визионари мира - мислиоци који могу да трансформишу тај симбол у хоризонт свести, перспективе, визије, мудрости која ће нам помоћи да се бавимо миром (и безбедношћу), као глобалним проблемом.“295

Јасно је да такве изјаве неће саме по себи обезбедити развој новог глобалног система безбедности, нити ће довести до престанка корозивне активности оружаних конфликата, који и даље постоје у многим деловима света. Нити ће оне довести до сигурнијег града или градова, или вратити нуклеарни дух у боцу. Али, оне су важна визија о томе шта може бити, па уколико те визије почну да трансформишу дискурс о безбедности, а људи почну да се понашају тако да све више изражавају ове нове визије, они пружају најбољу шансу да се уобличава сигурнији и безбеднији свет.

Задатак артикулисања и имплементације глобалног система безбедности неће бити лако, али негде се мора почети. Повраћај здравог разума и разумевања о томе шта је вероватно да ће производити безбедност и сигурност и улагање одређених напора у том правцу повољан је почетак. Оцртавање интуитивне природе безбедности и њено узимање здраво за готово, што је отелотворено кроз нормалне људске односе и размене, треба да обезбеди средства за утврђивање у којој су мери примењиве и на сложеније организације и системе. Није могуће да се макропроцес преслика на микрониво, али изгледа да микропроцеси негују многе трагове и решења како треба да се концептуализује и почне да реализује већа безбедност и сигурност у будућности.

Концептуализација света као недељивог глобалног ентитета кључни је елемент у остваривању заједничке међународне безбедности. Али су једнако важне и различите појединачне и колективне концепције глобалног система. Како може да изгледа глобални систем безбедности и које врсте институција треба да буду развијене како бисмо добили неки институционални израз за овај систем? Концептуализација глобалног система, упркос убрзаном развоју међународних невладиних и владиних институција, много је тежа него концептуализација знатно прегледнијих националних држава.

${ }^{295}$ Исто. 


\section{4 Безбедносна култура као фактор развоја националне безбедности}

Вра́тимо се још једном националном оквиру безбедности и безбедносне културе и размо̀тримо на које је све начине и укључујући које факторе, актере или институције могуће постићи да безбедносна култура допринесе развоју националне безбедности. Бројни су фактори који утичу на стабилност и развој националне безбедности. Поред војних, економских, политичких и технолошких фактора који проистичу из оснажености и стабилности демократских процеса и институционалне изграђености и ефикасности, веома су значајни и они који потичу из сфере културе, националне културе, а потом и безбедносне културе (видети схему 9).

Безбедносна култура која је проистекла из националне културе јачањем и оснаживањем, пре свега националног идентитета, кроз јачање националне воље, патриотске свести грађана и спремности да се бране виталне националне вредности, усмерена је и ка остваривању трајних националних циљева - све то, првенствено се ослањајући на сопствене ресурсе и капацитете у свим доменима развоја друштва.

\subsection{1 Трансфер националне културе у безбедносну културу}

Све што има предзнак национално̄г представља јасан израз једног посебног начина реаговања, и то нарочито на изазове глобалне и транснационалне промене. Национална „имагинација“ на посебан начин организује своје размишљање и одређује своје категорије као одговор на оно што се догађа у савременом свету. Када се говори о националној култури, а још више и о националном менталитету и поред бројних оспоравања када је у питању легитимност појма, подразумева се или бар претпоставља становиште јединства, интегритета, кохерентности, консензуса, заједништва - дакле, све 
оно што представља позитивну вредност, како културну тако и политичку вредност коју треба бранити и заштитити.

Познато је да „замишљена заједница“, као извор идентитета и као извор обавезе, најефикасније функционише када је заједница унитарна. Већ је наглашено у раду да су такве заједнице малобројне и тешко их је одржати. С обзиром на то да постоји опредељење за суштинско јединство, национална култура, која, између осталог, обухвата и начин мишљења и осећања, може да разноликост, различитост и комплексност доживљава као проблем. Различитост је проблем, зато што се доводи у везу са опасностима (које често такође, могу бити само „замишљене“ или „умишљене“), културног и политичког пропадања, раздвајања, као и нереда.

Свакодневна реалност је ипак испуњена различитошћу, са којом савремене нације треба да живе и да се суоче. Зато је важно да се пронађу механизми овладавања плуралитетом и последицама које настају када се тим плуралитетом не управља на одговарајући начин. О неким решењима за ова питања већ смо нешто рекли у првом делу.

Када је у питању јединство, у теорији су заступљене назнаке о снажном уверењу у неопходност постојања неке врсте повезујућег механизма „заједничког етоса“ (уцелињујућег начела - према Рут Бенедикт). Данас се још увек трага и тражи решење за то који би уједињавајући принцип могао да се успостави у неком друштву (у националним оквирима, на пример). Политички мислиоци најчешће износе став како би јединство требало везати за известан политички принцип, за неки концепт националног грађанства, где је оно схваћено као пристајање на скуп политичких начела као што су: толеранција, поштовање владавине права, веровање у процедуре парламентарне демократије и тако даље.

Познато је и да други теоретичари одбацују принцип грађанског национализма као основ заједничке идентификације, јер по њима, није довољно суштински; што значи да он не може објаснити зашто границе политичке заједнице треба да буду ту где су постављене, а не негде другде, затим, не пружа било какав осећај историјског идентитета заједнице, везе које спајају данашњу политику 
са одлукама донетим и акцијама изведеним у прошлости. Неопходно је, дакле, да постоји снажнија веза, која укључује потребу грађана да имају осећај свог историјског места и свог правог заслуженог места у савременом свету.

Пре него што се помире ове две супротстављене опције, важно је нагласити нужност трансфера акумулираног знања, искуства и других потенцијала из сфере националне културе у безбедносну културу како би она одиграла своју водећу улогу „чувара“ националне безбедности. Пре свега тога, потребно је утврдити на који се начин, којим средствима и ангажовањем којих актера то може постићи. О некима ћемо нешто рећи у тексту који следи.

\subsubsection{1 Просвећеност друштвене елите}

Идеја да одабрани треба да владају није нова, јер је још Платон говорио да филозофи, односно они који су супериорни јер су најмудрији, треба да владају друштвом или заједницом. Мудрост као критеријум за „одабране“, који су предодређени да владају, одавно је изгубила и устукнула пред једним другим, а то је моћ.

Према једном од најпознатијих теоретичара елите Рајту Милсу [Wright $C$. Mills], елита заузима највише командне позиције друштва. Друштвена моћ је концентрисана у елитним групама које контролишу ресурсе кључних друштвених институција. При том, испољавају огроман ауторитет не само над државним већ и финансијским, образовним, социјалним, грађанским, културним институцијама. Представљају мале групе, али су у могућности да покрену фундаменталне акције које дотичу и мобилишу све грађане. Примера ради, одлуке које се доносе у „дому бардова“ великих корпорација и банака утичу на стопу инфлације и запослености. Такође, потребе индустрије у великој мери одређују приоритете и политике образовних и истраживачких организација, али и главних економских агенција владе.

У теоријској литератури и истраживањима наводе се различити критеријуми формирања и разликовања елита. Сумирајући ставове више теоретичара, можемо говорити о елитама моћи, културним елитама, затвореним и отвореним елитама, елитама које разматрамо према степену структурне интеграције и 
степену сагласности око вредности. У складу са овим поделама, када се говори о националним елитама, разликују се три важне конфигурације: разједињене, консензусом обједињене елите и идеолошки уједињене елите.

Међу америчким теоретичарима влада мишљење да владајућа елита, која има моћ, црпе своје чланове из следеће три области: 1. највише политичке лидере, укључујући председника и неколико кључних чланова кабинета и блиских саветника, 2. велике корпоративне власнике и генералне менаџере, 3. високе војне официре. Тиме је и снага елите унапређена блиском сарадњом политичке, економске и војне организације.

Полазећи од става да се сва политика своди на борбу за власт, а да ултимативну врсту власти чине сила и насиље, Милс у својој књизи Елита власти објашњава како су врхови војске постали током XX века део елите моћи. „По целом свету се сада стварност уобличава како то војне главешине хоће. Па и у Америци су у политички вакуум умарширали господари рата, војне главешине. Поред извршних органа великих привредних корпорација и политичара, сада генерали и адмирали - ти пријатни рођаци америчке елите - стичу и добијају све већу моћ при доношењу одлука, односно све више утичу на доношење оних најкрупнијих одлука.“296 Један од разлога повећаног значаја војне елите лежи, по Милсу, и у чињеници да је војска у савременом америчком друштву постала један од, појединачно узето, најснажнијих организатора научног и технолошког напретка и регулатора научних истраживања. Тако је и у неким другим друштвима.

Просвећеност једног народа, а нарочито друштвене елите, када је у питању безбедност, изузетно је важна, јер подстицај и развој безбедносне свести која је у темељу безбедносне културе доприноси развоју и очувању националне безбедности. Елита има задатак или улогу да, добро утемељена у свом знању и могућностима, шири најбоља знања, најбоље идеје свог времена, ослободи знање од свега што је грубо, просто, тешко, апстрактно, стручно, ексклузивно, да га хуманизује (најчешће улога културне елите) и учини га делотворним

\footnotetext{
${ }^{296}$ Рајт Милс, Елита власти, Култура, Београд, 1964, стр. 226.
} 
изван клике култивисаних и учених; и поред свега, да и даље остане најбоље знање и мисао тог доба, па тако и истински извор свежине и светлости. ${ }^{297}$

Како ће се дефинисати безбедност под утицајем је договора између државног руководства и елите. То је динамичан процес и питање прерасподеле моћи и дефиниције безбедности морају да буду посредно постављене и у континуитету. Колико добро руководство успева да максимизује своју аутономију упоредо са учешћем променљивих притисака друштвене елите одређује природу и степен политичке стабилности и постизање безбедности. Критична улога руководства лежи у његовој способности да балансира сопствена занимања са интересима друштвене елите.

У уобичајеним околностима политика има циљ да развије међународни и унутрашњи дискурс о безбедности да буду компатибилни док међусобно обликују један други. Фактор стабилизације структуре која се јавља током времена интеракцијом ова два дискурса јесте безбедносна култура, као скуп вредности, норми, правила и пракси у вези са безбедношћу која дају размишљање и образац деловања у пољу безбедности одређене државе. Државе у једном региону понекад могу да деле скуп културних вредности или безбедносну културу у целини. Безбедносна култура дефинише идентитет и тако обликује преференције и приоритете. Тако акције и реакције у одређеним ситуацијама помажу да се објасне значајне разлике у политикама безбедности међу државама које могу да деле исто безбедносно окружење и/или су снабдевене са доста сличних домаћих институција. ${ }^{298}$

Уколико се држава првобитно определила за кооперативне односе са окружењем или у оквиру неког савеза, специфичне супкултуре или, у овом

297 Метју Арнолд, „Култура и анархија“, Студије културе - Зборник, Службени гласник, Београд, 2008, стр. 37-42.

${ }^{298}$ Peter J. Katzestein, „Introduction: Alternative Perspectives on National Security“, in The Culture of National Security: Norms and Identity in World Politics, edited by Peter J. Katzestein, New York: Columbia University Press, 1996; Keith Krause, „Critical Theory and Security Studies the Research Programme of Critical Security Studies“, Cooperation and Conflict, Sage Journals, 1998. 
случају, елите могу да утичу на способност државе да одржи такве односе. Традиције, вредносне оријентације и дубоко укорењени приоритети од стране војске могу да имају одређени утицај на безбедносну политику и олакшати или отежати сарадњу у безбедности. Као пример могу да послуже одлучујуће војне експертске групе које дају виртуални вето над одлукама, за или против сарадње у области безбедности, или се њихови ставови преносе преко друштва и утичу на безбедносну културу једне земље.

\subsubsection{2 Национални систем образовања}

Смисао и улога образовања у савременим друштвима огледају се у ставу да оно треба да омогући развој друштва, његову савременост, извеснију будућност, квалитет живота и услове да чланови тог друштва живе слободно и срећно, односно да остваре „идеал мира и социјалне правде“. Као предуслов напретка, образовање је саставни део најширих и најзначајнијих друштвених преокупација у свим земљама света. Оно припада „само“ мекој моћи националних држава и као такво једно је од најмоћнијих средстава за културно, етичко, професионално формирање личности у условима научно-технолошке револуције, демократизације друштвеног живота и тржишне привреде.

Готово све теоријске расправе и анализе заснивају се на прихватању, подржавању и развијању потреба да се образовни систем ухвати укоштац са савременим проблемима којима обилује свако друштво, и развијено и неразвијено. С тим у вези се прокламују стратешки циљеви који подразумевају: унапређење образовања сходно променама, представљање образовања као развојног ресурса на националном и локалном нивоу, усаглашавање са европским тенденцијама и интернационализацију, али и уважавање образовања као инструмента очувања и развоја националног и културног идентитета. Свака култура развија институције за васпитање и образовање које члановима групе/друштва преносе знања важна за развој, очување и опстанак те групе. Форме у којима се такво знање уводи и преноси могу бити разноврсне.

Унапређење образовања, сходно променама којима је једно друштво захваћено, мора уважити и оне промене које преиспитују досадашњи политички, државни, 
економски, образовни и културни идентитет. Сва савремена збивања крећу се у оквирима општег, планетарног преплитања идеја, догађаја, актера. Сложена међузависност диктира развој економије, технологије, политике, медија и других чинилаца, а њен први плод је постепено потискивање националних суверенитета и разарање локалних идентитета пред инвазијом моћних транснационалних институција и процеса. Ова глобализација подразумева стварање нових културних блокова и синтеза, али и губитак, нестајање - у распону од декултурације до отвореног етноцида - бројних мањинских култура. $^{299}$

Такође можемо приметити то да су сва савремена друштва у мањој или већој мери изложена утицајима ових садржаја, и то посебно образовни и културни системи. Све чешће се у локалном миљеу репродукују социјалне установе, вредности и обрасци понашања глобалног друштва. Животни стилови, аспирације, доколица, потрошња, рад, информације и слично - носе дубоке трагове глобалне културне хомогенизације, оријентишу се и сагле́дају мерилима и трендовима глобалне културе. Као одговор на ове утицаје пожељно је да свако друштво и/или држава изграђују своју концепцију усвајања тековина „светског друштва“ [world society], односно интеграције у глобализоване социјалне и друге институције, али и буде свесно модела понашања, интелектуалних и материјалних ресурса који прате глобалне културне токове. Наравно, локална верзија глобалне културе сучељава се са локалним културним идентитетом, националним културама, чије преобликовање може имати и тешке патолошке последице, те угрозити саму идеју културног диверзитета или плуралитета култура.

Поред турбулентних промена у сфери економије и убрзаног протока информација, плурализам вредности је такође једна од најуочљивијих одлика савременог света, али исто тако на националном и међународном плану значајно је присуство дискриминације и насиља. Друштвени оквир у којем

${ }^{299}$ Antony D. King (ed.), Culture, Globalization and the World - System, London, Macmillan, 1991; према: Триво Инђић, Технологија и културни идентитет, Службени гласник, Београд, 2009, стр. 126. 
егзистирају и делују појединци и групе испуњен је несигурношћу у погледу остваривања људских права и слобода, поштовања институција и принципа демократског развоја и просперитета.

Пошто је савремени свет пун противречности, незаобилазно је поставити питање колико и на који начин образовање може да утиче на избегавање конфликата, на развијање свести о „другима“, о постојећој међузависности, изазовима, ризицима и претњама који оптерећују свакодневни живот, а који ће људе покренути да се суоче са њима и одговоре на прави начин; такође, да покрене људе и на међусобну сарадњу. Ниво образовања, квалитет образовања и образовна постигнућа утичу на то како се човек односи према самом себи, другим људима, припадницима различитих етничких група, човечанству. Због тога је веома важно како се одређују и конституишу садржаји наставних планова и програма на свим нивоима националног система образовања, како се и који кадрови обучавају за преношење тог знања и у којим се условима оно спроводи.

Нашу пажњу треба да заокупи и чињеница да је модерни образовни систем, према мишљењу многих теоретичара и аналитичара, раздвојио један сегмент живота од другог, одвојио научну анализу од филозофске спекулације, технологију од „хуманологије“, науку од уметности, интуицију од интелекта и самим тим довео до превласти техничког знања и његових несумњивих резултата. Такође, довео је до сужавања видокруга човекове мисли и делатности, тако да се смањила његова аутономија као индивидуе, његова способност да се одупре нарастајућем апарату масовне манипулације, његова снага имагинације и његов независни суд. Напредак техничких средстава просвећивања, као што смо већ приметили, пропраћен је процесом дехуманизације, па такав напредак прети да поништи са̂м циљ који треба да се оствари - идеју човека.

Образовање, као што знамо, има задатке ширег друштвеног значаја - да упути људе и приволи их људским правима, естетским, моралним, етничким, националним, културним и универзалним хуманистичким вредностима, да их научи разумевању неопходности међународне сарадње и очувања светског 
мира и безбедности као услова егзистенције свих људи. У савременом друштву се све више истиче значај образовања, посебно због усложњавања свих форми живота и увођења високих технологија. У том смислу је подизање нивоа безбедносне културе кроз национални систем образовања значајно за спасавање људске заједнице од (само)уништења, при чему се највише рачуна на снагу људског разума и његову културу.

Духовност коју је појам безбедности поседовао у древним временима и која је у међувремену изгубљена - култура је успела да врати у његово поље, управо кроз концепт безбедносне културе. Образовни аспект безбедносне културе, који је утемељен кроз оквир националног система образовања, мора да испољи и развије управо и ту димензију, која ће „оплеменити“ хладну технолошку сферу, која иначе доминира. Тиме ће се опремити не само потребним знањима рационалног и логичког карактера, већ и знањима и вештинама, веровањима и вредностима које проистичу из интуитивних, креативних, духовних облика знања потребних сваком члану друштва који је у процесу образовања, а и осталима. $^{300}$

Јединствени национални образовни програми морају се креирати управо тако да промовишу оне вредности које су значајне за будући заједнички живот и идеје које ће донети стабилност, а надасве безбедност за целокупну заједницу; такође, да испуне и услове који обухватају традиционалне вредности везане за живот свих групација на том простору, да буду атрактивне за све слојеве друштва, да озбиљно одговоре на изазове и да буду атрактивни за земље из окружења, са којима најпре сарађује и развија добросуседске односе.

\footnotetext{
${ }^{300}$ Макс Вебер је позивајући се на Ничеа, говорио о „стручњацима без духа, уживаоцима без срца“ као типичним представницима модерне културе. И један и други тиме указују на проблем знања које се непрекидно увећава, али које се више не може повезати ни са чим људским као својим средиштем. Видети:Алаида Асман, Рад на нащионалном памћењу, Библиотека XX век, Београд, 2002.
} 


\subsubsection{3 Образовање према циљним групама}

Свакако најважнија група која је у процесу образовања и која је потребно да буде обухваћена процесом усвајања знања и принципа што промовише концепт безбедносне културе јесу деца и млади. Образовање, као што знамо, има веома важну улогу информисања и формирања деце и младих као активних и одговорних чланова заједнице у којој живе. Један од основних циљева образовања ${ }^{301}$ јесте развити самосталан лични идентитет младог човека, чему треба да допринесу сви наставни предмети и целокупан васпитно-образовни процес.

Као што је већ познато, наставни предмети који највише предњаче као носиоци националних обележја јесу матерњи језик и књижевност, историја, географија, али и предмети посвећени културном стваралаштву одређене националне заједнице. Ови наставни предмети пружају основна сазнања о култури народа којем се припада, његовој историји и географским обележјима територије на којој се живи, али и знања о другим народима и културама. Пригодним садржајима у оквиру тих предмета ученици могу најлакше усвојити основна знања о свом националном пореклу и развити свест о поседовању специфичних културно-антрополошких, национално-историјских, вредносно-обичајних и језичких обележја. Уз упознавање културних посебности сопствене националне заједнице, пожељно је да ти предмети усмеравају ученике на разумевање и поштовање других народа, на прихватање разлика произашлих из утицаја другачије средине и на усвајање и поштовање основних људских права и слобода.

Тиме се, као што смо раније већ нагласили, ствара основа за трансфер културног обрасца као друштвеног ресурса развоја преко гранања образовања у

301 Данас се све више говори о новим приступима образовању, који су назначени у бројним стратегијама образовања за XXI век и који се могу операционализовати кроз четири образовна циља која морају да се остваре: учити да би се знало, учити да би се радило, учити да би се живело заједно и учити да би се било/живело (остваривање људске целокупности, развој личног и групног идентитета, самопоштовања и самоуважавања). 
правцу безбедносне културе, ${ }^{302}$ организационе, као и професионалне културе рада и стваралаштва. На тим основама се гради идентитет младих као аутентичан темељ за обликовање људских ресурса једне земље и за њихову спремност да се суоче са свим изазовима, ризицима и претњама које их окружују.

Образовањем се, иначе, више развија и јача одређени систем вредности и обичаја које једно друштво настоји да промовише у свим приликама, а они даље утичу на избор садржаја којима ће се дати преимућство у преносу знања и средствима која ће користити да би остварили те циљеве. Образовни процес мора бити обогаћен и хуманистичким садржајима, а хуманистичко образовање мора постати део опште културе и културолошке самосвести сваког појединца. На тај начин се култивише и обогаћује личност појединца и групе, и пружа им се шанса да успешније пронађу и изграде свој идентитет и сагледају сва ограничења, препреке и изазове глобалног друштвеног развоја. Развој идентитета представља суштину развоја и филозофије образовања за XXI век и њен најважнији циљ.

Откривањем властитог идентитета (издвајањем цивилизацијских колективних вредности из културне историје света и сопственог народа) развија се не само колективно памћење, већ се омогућава откривање и чување властитог групног и индивидуалног идентитета, али и других личних и друштвених вредности. При том се развија осећај припадности свом народу, али и човечанству, па се, с једне стране, негује национални идентитет, а с друге, развија и обогаћује дух „Планетарног човека“.

Позната је већ и у раду поменута мисао која политичка размишљања, активности и одлуке представља као безбедносни пројект. Архитектура савремене политичке моћи, која је оличена у држави и у институцијама и појединцима, укључујући савремене демократске политичаре, своје кључне

302 Било је већ успешних покушаја да се предмет Безбедносна култура уведе у образовне програме средњих школа и на факултетима у Републици Србији и у Босни и Херцеговини. Као резултат одређених пројеката и програма у образовним установама, објављене су и прве публикације из ове области, које смо већ представили раније у напоменама. 
премисе гради на темељима безбедности и безбедносних потреба. Управо из тог разлога важно је да политички лидери који се позивају на безбедност располажу знањима и умећима који ће помоћи да се безбедносна култура оствари примењујући адекватна политичка, економска, културна, војна, полицијска и друга средства. Креатори политике и стратези склони су да виде ситуацију кроз свој културни „објектив“, са недовољно разматрања и калкулација перспектива и интереса других, те је у том смислу потребно озбиљније порадити на њиховом образовању.

Неке културе и политике, као што смо видели у претходним излагањима, одређене су према безбедности на Хобсов начин, а неке на Кантов. Начин на који ће се остварити и применити безбедносна култура у једном друштву не умањује значај и одговорност владајућих политичких снага, као једне од циљних група које су важни промотори тог концепта. Зато се и они идентификују као циљна група која треба да буде одговорни носилац трансфера националне културе у безбедносну културу и који се морају укључити кроз неку форму образовног процеса како би стекли, а затим и оправдали тај статус. На сличан начин можемо посматрати и кадрове/људске ресурсе из безбедносних структура.

Медији, као средство и организација преко које се преносе поруке широкој и друштвено мешовитој публици, такође су веома значајна циљна група која треба да буде део образовног процеса и активности, кроз које се садржаји националне културе представљају на начин да доприносе промоцији и развоју безбедносне културе трансфером акумулираних знања и вредности. Средствима масовних комуникација управљају менаџери одређених профила и са посебним стручним знањима, али који у сваком тренутку морају бити свесни значаја безбедносне културе и потребе да обогате своје програме, рубрике и сајтове образовним садржајима који шаљу поруке мира, толеранције, поштовања и уважавања других и другачијих, упозорења о ономе што може да повреди, разболи, манипулише или „заведе“. 


\subsection{2 Трансфер националне безбедности у безбедносну културу}

Као што из досадашњег излагања можемо да закључимо, национална безбедност представља вишу форму развијања интереса безбедности пренету на људске структуре и ентитете, као полазне и темељне структуре за концептуализацију културе, безбедности, а потом и безбедносне културе. Да би се извршио трансфер националне безбедности у безбедносну културу, неопходно је подржати активну, конститутивну улогу нације у оквиру безбедности политичке заједнице, изградити националну свест припадника̂ политичке заједнице, кроз изграђене државне и друштвене институције развијати понашања заснована на моралним и етичким начелима и поштовању норми, оријентисати је према неким важним вредностима које се изграђују и кроз институције образовања, културе, привредне структуре и сличне механизме.

Национална безбедност, без обзира на начин интерпретације и начине употребе, заснована је на различитим културно-историјским традицијама и носи у себи вредносно-нормативни потенцијал, који се може уобличити и уоквирити кроз безбедносну културу. Да би се извршио трансфер, веома је важно усагласити факторе који, с једне стране, доприносе различитим аспектима живота нације, а с друге, угрожавају облике и начине реализације.

Успоставити и сачувати националну безбедност озбиљан је изазов, посебно када постоје различити изазови који подривају национални идентитет, а могу се препознати и у неким наднационалним структурама. Трансфером у безбедносну културу национална безбедност добија преко потребну стабилност, утемељену у културалним компонентама које играју доминантну или значајну улогу у реакцијама и понашању државе и њених институција, друштвене групе или појединца у односу на безбедносну претњу.

\subsubsection{1 Безбедносна култура и државне институције}

Држава је основни и уједно и даље најзначајнији облик организовања друштва и носилаца власти на одређеној територији. Такође, она је правни субјект 
унутрашњег и међународног права, али и регулатор најважнијих процеса и односа како у сфери економије, политике, тако и у сфери безбедности, културе, образовања и свих других делатности које доприносе остваривању појединачних, заједничких и општих циљева, потреба и интереса.

Држава се одувек, па чак и данас, када је њена улога у том погледу редукована, сматра главним „едукатором“, управо због тежње да створи нови тип и ступањ цивилизације. Поред тога што она суштински делује на економски потенцијал, снаге и развој економске производње и стварање нове структуре, она има веома важну улогу и када су у питању фактори „надградње“. Наиме, и на том пољу држава и њене институције представљају инструмент рационализације и убрзавања развоја и напретка. Она делује плански, подстицајно и усмеравајуће, с једне стране, али, с друге, и „кажњава“, јер када се створе услови у којима је одређени начин живота „могућ“, „кривично дело или прекршај“ мора имати казнену санкцију с моралном импликацијом, а не тек генерички осуђено као „опасно“. 303

Држава је организацијска, референтна целина, где се најбоље одражава могућност да се развије безбедносна култура, која ће кроз активности државних институција остварити преко потребну легитимност држави да влада и управља грађанима-држављанима. При том, уважавајући чињеницу да су грађани делегирали свој суверенитет у суверенитет државе, како би се остварила њихова безбедност. Да би се то постигло, неопходно је и поштовати људске вредности као меру за реализацију основних егзистенцијалних могућности које ће безбедносна култура уградити у оквир деловања државних институција.

\subsubsection{2 Безбедносна култура и друштвене институције}

Безбедносна култура као значајна компонента рада и развоја индивидуе, групе или колективитета постала је и једно од најширих подручја целокупног

\footnotetext{
${ }^{303}$ Антонио Грамши, „Хегемонија, интелектуалци и држава“, у: Студије културе - Зборник, Службени гласник, Београд, 2008, стр. 148-154.
} 
друштвеног живота. Савремени друштвени простор, са сложеном и динамичном друштвеном структуром и друштвеним односима, представља својеврстан изазов за успостављање и развој специфичног односа безбедносне културе и одређених димензија друштва, па тако и друштвених институција.

Свако друштво има своје друштвене институције. То нису објекти, зграде или нека друга места, већ специфична структура односа, обавеза, улога и функција. То су друштвени концепти и праксе, али такође укључују когнитивне структуре. Чланови друштва имају заједнички ментални концепт добро̄г и лоше̄г, реда и односа, као и специфичне обрасце добро̄г (позитивне вредности). Они који не поштују ове појмове асоцијални су, припадници криминалног миљеа и углавном на маргинама друштва (то чак могу бити и изузетно надарени појединци, у исто време несхваћени или појединци који представљају „црне овце“).

Друштвене институције се изграђују у сфери политике, економије, религије, језика, образовања, уметности и другим подручјима. Ове институције су значајне и виде се као посебни фактори друштвеног идентитета, а важни су за разумевање друштва и интеграцију у друштво. Свака од ових институција има јединствену историју и специфичну функцију у очувању друштвених норми, вредности, културе и веровања. Самим тим је значајно одредити и назначити важност ових институција у трансферу националне безбедности у безбедносну културу и њеном промовисању.

Институције које регулишу понашање појединца у кључним областима друштва, а самим тим и безбедносне културе свакако су:

a) породица и мрежа друштвених односа за спровођење репродукције и социјализације (Као што знамо, породице и породичне везе представљају места где деца одрастају и стичу примарну социјализацију. У идеалном случају породице се одликују великом осећајношћу, бригом и дружењем, а своје чланове обасипају љубављу и партнерским односима, помажући им да се осећају заштићено, безбедно и задовољно. Породице несумњиво имају кључну улогу у репродукцији статусне позиције. Наиме, деца наслеђују друштвени 
положај, који умногоме произлази из породичног стабла, односно социо-економског статуса и угледа његових предака);

б) институције у области образовања и обуке које треба да обезбеде пренос и неговање знања, способности и специјализованих вештина;

в) институције у области тржишта рада и привреде које треба да обезбеде производњу и дистрибуцију робе и услуга;

г) институције у области владавине права, политике које треба да обезбеде одржавање друштвеног реда и стабилности;

д) на крају, издвајамо културне, медијске и верске институције, које треба да обезбеде развој контекста значења, вредносних оријентација и симболичких кодова.

Веома важно питање када се говори о друштвеним институцијама јесте питање институционалних појава, њиховог континуитета и промена. Између влада и научника из области друштвених наука постигнута је сагласност да институције нису статичне. Процеси институционализације и дезинституционализације одређених образаца понашања јављају се стално. Током времена се мења и значење институција. Оне, такође, могу бити локус друштвене промене. На пример, институција породице је претрпела суштинску промену још од средине XX века, а у међувремену су породичне форме постале веома различите. ${ }^{304}$

Институција цркве је такође претрпела трансформацију у свом значењу и функцији. У предмодерним друштвима производња и пренос нових знања били су једна од централних функција верских институција, поред ширења вредносних оријентација и културних кодова. У савременим друштвима образовне институције су преузеле први задатак, док је црква ограничила своју мисију да преноси значење и тумачење света. Међутим, институције културе и

\footnotetext{
304 Модел породице је повезан са сексуалношћу, саживотом и подизањем детета у јасно дефинисаном институционалном облику названом брак - при чему се јавља низ нових облика породичног домаћинства (неудати/неожењени родитељи, хомосексуална домаћинства, породице без деце и слични облици заједница).
} 
медијске сфере све више постају конкурентне цркви управо у овој области. У исто време модерна друштва су сведоци нових пракси, где се врши диференцијација верске праксе и где расте плурализам светских религија.

Промене у функцији и промене у значењу институција веома су важне, а безбедносна култура и њена улога у тим трансформацијама битна је, јер их може ојачати или бити извор најбољих решења и одговора на проблеме које трансформација може изазвати (схема 9).

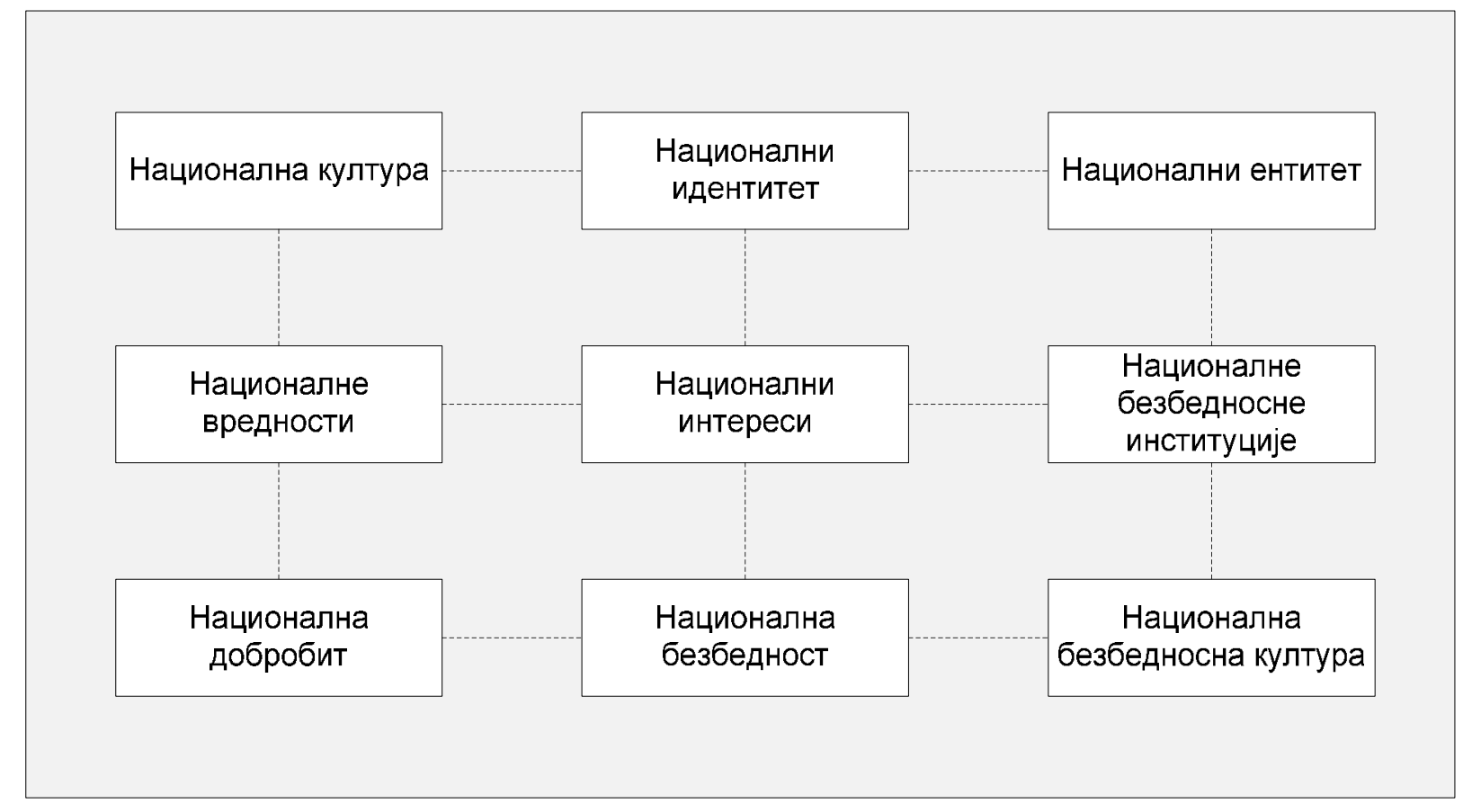

Схема 9. Концептуална анализа безбедносне културе

\section{5 Институционални развој безбедносне културе}

Формулисање неке идеје, принципа или концепта културно је безначајан ако се и све док се не преведе у организовани склоп здружених активности. Претварање изума (идеје) појединца у стандардну својину заједнице и њено 
учвршћивање у институционални систем деловања или понашања означава прелаз из прекултурне у културну фазу једне заједнице. Институционална структура је универзална, без обзира на карактер и облик културе, на њено порекло, развојни степен материјалног или духовног живота, карактер друштвених односа и друга специфична или локална обележја која припадају једном културном ентитету.

Свако друштво има одређене институције које регулишу друштвене односе и начин дистрибуције друштвених улога и положаја прописујући одговарајуће облике понашања. Друштвени живот је увек институционализован, а то значи подвргнут одређеним правилима која појединци и друштвене групе морају усвојити да би друштвени систем несметано функционисао: од сродничког система, као универзалног институционализованог оквира, преко појаве државе, као средишта правног институционализовања друштва, до сложених модерних друштвених система са диференцираним подсистемима и специфичним институцијама.

Познато је да институције уносе ред у друштвене односе, редукују флексибилност и варијабилност понашања те ограничавају могућности једностраног остваривања личног интереса или нагона. Основна логика деловања јесте слеђење правила̂ - прескрипција које се заснивају на логици прикладности и на осећају права и дужности које произлазе из идентитета и припадности (политичкој) заједници и њеном етосу, односно праксама и очекивањима од њених институција. Логика прикладности се односи на појединачну културу. Не постоји претпоставка о нормативној супериорности. Логика прикладности може произвести истинољубивост, правичност, поштење, поверење и великодушност, али и крвне освете, одмазде и етничке сукобе у различитим културама. ${ }^{305}$

Уколико јасније изградимо у теоријском смислу проблемско поље, јаснији и садржајнији ће бити приступ изградњи инситуционалне мреже у оквиру које ће се водити координација фактора релевантних за националну безбедност.

305 Институције и институцчионализам, приредили: Петар Бојанић, Иван Младеновић, Службени гласник, Београд, 2010. 
Самим тим ће се стварати услови и могућност да се кроз постојећу мрежу институција уведе и безбедносна култура или да се стварају нове институције у складу са поставкама овог концепта. То може да подразумева креирање студијских образовних програма, института и центара за истраживање и промоцију безбедносне културе, формулисање кључних докумената, укључујући стратегије, развој база података и националних инвентара, имплементирање принципа и поставки безбедносне културе у безбедносну праксу субјеката безбедности, развијање и јачање техничких и менаџерских капацитета у том и у другим секторима, и слично.

\subsection{1 Безбедносна култура и друштвене интеграције}

У модерном свету постоје друштва која се реконституишу, траже своју стратегију развоја и свој идентитет те интензивирају напоре у правцу властитог унутрашњег интегрисања. Отуда се анализа о интеграцији и институционализацији безбедносне културе кроз тај процес може усмерити на питање друштвене интеграције појединачне политичке заједнице и њеног државног организовања, с једне стране, али исто тако и на глобални ниво, изражен кроз супранационалне и наднационалне организације, с друге стране.

У тумачењу концепта друштвене интеграције нужно је узети у обзир две димензије појма интеграције и двоструку рефлексивност самог феномена: с једне стране, интеграција подразумева стање ствари, што указује на степен унутрашње кохеренције у једном систему и сврховитог деловања људи у њему; с друге, реч је о процесу, односно развоју којим се постиже већа унутрашња кохеренција у систему. У том случају интеграција претпоставља и функционалну диференцијацију, која је с њом у вези. У савременој социолошкој перспективи концепт интегративизма базиран је на две парадигме: на парадигми конфликта - где је интеграција минимална; и на парадигми поретка - у којем се социјетална интеракција темељи на кохезији, консензусу, кооперацији, реципроцитету, стабилности, хармонији и истрајавању. 
Савремене државе чине снажно интегрисане друштвене групе, чије је становништво подвргнуто високим правилима и механизмима принуде, која служи као спољна заштита и као механизам унутрашњег подређивања и политичке промоције. То значи да јачање интеграционих фактора претпоставља и повећање подређености, с једне стране, али и већу државну заштиту, с друге стране. Обратно, повећање подређености и заштите имплицира повећање интеграције. Слабљење интеграционих процеса и веза̂ доводи до смањења подређености, али и заштите. Што је интегрисаност већа, а заједнице згуснутије, то су мере политичке власти непопуларније.

Питање интеграције једног друштва концептуализује неколико фактора, од којих су најважнији - изградња демократске државе и очување становништва. У темељу ових основних интегративних постулата налазе се: адекватне политичке установе и политичко јединство, државотворне политичке партије, владавина права, тржишна економија и ефикасно привређивање, разрађен социјални подсистем, културно заједништво и склад у разноликости, затим националност и територијални оквир државе. За ове постулате битно је и постојање система интересних организација, критичких група и грађанске иницијативе, слободног развијања и деловања јавног мњења и политичке јавности.

У друштву које успева да одржи своју унутрашњу интегрисаност могуће је и очување властитог идентитета, вредности и традиције и остваривање фундаменталних државних и националних интереса. Осим тога, интегрисано друштво лакше решава кризне и конфликте ситуације, а уједно је и мерило развијености и имплементираности безбедносне културе у друштвену структуру и друштвене односе.

\subsection{2 Безбедносна култура и однос према држави}

Једно од најважнијих и заправо суштинских питања сваког друштва и у националним оквирима јесте изградња државе. Своју моћ и стабилност држава достиже развијањем способности управљања или јачањем капацитета, тј. 
квалитета институција. То је важно и за њен општи развој и за заузимање значајних позиција на међународној сцени, које ће јој омогућити стабилност, сигурност и безбедност. Као важна претпоставка мора се уважити чињеница да иницијативе и подстицај за развој институција, као предуслова безбедности, треба проналазити унутар државе и међу „домаћим актерима“. Насупрот овоме, ту важну улогу преузимају међународне институције и организације за помоћ, донатори, зајмодавци и слични који нуде услове, програме и пројекте за структурално прилагођавање, а заузврат носе много проблема, ограничења и притисака.

У савременим условима, и поред свих противречности и критичких размишљања, суверена територијална држава је и даље стандардна јединица и референтни оквир у којем се разматра безбедност. Држава је кључни субјект који је способан да суверено остварује своју власт, а самим тим организује и чува националну безбедност у складу са националним интересима. Она кроз међународне и унутрашње правне норме дефинише јасне одреднице концепта националне безбедности у политичком и правном смислу и адекватном безбедносном политиком остварује важну улогу у животу и опстанку нације. Безбедносна политика укључује низ механизама и средстава којима осигурава безбедност на свим нивоима, а када је у питању држава, она подразумева очување државног суверенитета, мира и благостања.

Да би се изоштрило разумевање потенцијала и границе безбедносне политике, па самим тим и унапредила текућа дебата о актуелним безбедносним проблемима, морају се уважити и безбедносна култура и могућности њене трансформације. Држава би требало да буде политичко тело сопственог националног суверенитета, а интерес националне безбедности мора уважити културно-историјску суштину и природу настанка те исте државе. Безбедносна култура се јавља као специфичан одраз културно-историјске суштине и, негујући културне вредности и вредности нације, задржава и специфичан однос према држави која је на тим вредностима заснована. У том смислу се јавља и тежња да се, поред уважавања права мањинских националних заједница, мора пронаћи начин да се заштите и права већинске националне заједнице. 


\subsection{3 Безбедносна култура и међународни односи}

У савременим међународним односима безбедносна култура има специфично место и позицију, али је у сваком случају одраз појединачних националних безбедности држава и њиховог приступа питањима безбедности на међународном плану. Познато је, такође, да је међународна безбедност настајала не само у циљу заштите вредности појединачних држава, него и у условима повећане међузависности држава, одражавајући шире вредности, које превазилазе националне оквире. На основу досадашњег понашања држава у међународним односима не постоји висок степен сагласности међу државама о којим је вредностима реч. У сваком случају, у новијим расправама о безбедности уочава се појачање свести о неопходности и значају усаглашавања око одређених вредности, интереса и успостављања приоритета међу њима.

Током историје међународних односа издвојила су се два модела којима се настојала остварити међународна безбедност, и то конфликтни и кооперативни, а оба су већ била предмет наше опсервације.

Промене у међународним односима крајем XX века до те мере су велике да се може говорити о зачетку новог система односа у свету. Те промене су резултат промена на унутрашњем плану држава, али и нове улоге економског, технолошког и информатичког развоја, који су допринели јачању међузависности и нових приступа безбедности, суверенитету итд. У том духу се одвијају и промене када је у питању концепт безбедносне културе и његови нови аспекти развоја и промоције како унутар државе тако и на међународном плану.

\section{6 Манифестације безбедносне културе}

Када је реч о манифестацијама и начину испољавања безбедносне културе у различитим контекстима, референтним оквирима, па и свакодневном животу, можемо је детектовати на основу знања која поседују и којима имају приступ 
(појединци, групе итсл), ставова које изражавају о безбедности и безбедносним појавама, начину понашања према предвиђеним правилима и прописима у односу на потенцијалну опасност и ризик, или кроз симболичку комуникацију коју развијају. То како се манифестује безбедносна култура када је у питању држава и када говоримо о нивоу националне безбедности у односу на међународно окружење, у раду смо више пута представили. Даље у тексту видећемо кроз наизменични приказ и других референтних оквира како се одвија тај процес представљања и манифестовања безбедносне културе.

\subsection{1 Безбедносна култура као систем знања}

Значај размишљања и нових приступа безбедносној култури заснива се на чињеници да безбедност постаје витална и централна вредност у савременим условима. Заштита ове вредности и редовна репродукција услова који се огледају у концептима безбедности превазилазе задатке које обављају појединачне државе (односно јавни институционални системи). С једне стране, развијају се системи компликоване међународне сарадње, а с друге, актери пословног сектора и цивилног друштва имају све већу улогу. Паралелно са овом тенденцијом, мора се посматрати губитак функција у савременим националним државама, што, наравно, утиче на њихову одбрамбену и безбедносну функцију.

Јавне институције, лишене својих релевантних безбедносних и одбрамбених улога, губе део својих функција, апсорбују много буџетских средстава и на један парадоксалан начин намећу повећање ризика за безбедност кроз њихово пуко постојање. На основу тога, политички моћници, партије и владе различитих земаља имају велику одговорност у настанку и развоју одговарајуће безбедносне политике. Иако посредно, безбедносна политика и даље коначно одређује део националног прихода у одређеној земљи, који, заузврат, може да се користи за објективне захтеве одбране и безбедности те начине њихове примене. Идентификација објективних потреба је одговорност научника, али консултације, конфронтације и спровођење различитих интереса зависе од политике и политичких циљева који су иманентни објективним 
потребама. Спровођење циљева безбедносне политике пре свега је задатак владе.

Поред државе и њених органа, присутни су и други актери који имају важну улогу у осигуравању безбедности и заштите. Актери морају бити свесни релевантних безбедносних ризика и потенцијалних превентивних акција у мери у којој играју одређене улоге, морају преузети одговорност и предузети кораке да унапреде безбедност свог окружења. Ово се може постићи само ако безбедносне снаге и државни органи не сматрају да су ексклузивни представници безбедности и одбране, и поседници информација и сазнања у вези са тим, већ морају да предлажу дијалог и сарадњу са другим актерима друштва у духу једнаког значаја. Упркос тежњи да се постигне подједнака важност, могу постојати разлике у могућностима и способностима, а очигледно је да разлике заиста и постоје.

Ова ситуација се, дакле, може превазићи сарадњом и дијалогом. Дијалог и сарадња су потребни разним међународним организацијама, владама других земаља, представницима цивилног друштва и актерима пословног сектора. Дијалог и сарадња помажу добијању нових информација које су неопходне за решавање проблема. Ове информације су од виталног значаја како за признавање нових објективних потреба, тако и за успостављање услова битних за задовољавање тих потреба. Очигледно да је важан услов дијалога и сарадње довољна количина информација, вештина и знања, коју актери морају да имају. Ово је посебно важно да се обезбеди у сектору безбедности, где се информације и знање и институционално чувају и где је њихов ток правно регулисан. ${ }^{306}$

Ширење знања и информација потребних за дијалог и сарадњу није једноставан задатак. Чак ни неко традиционално интензивно ширење

\footnotetext{
${ }^{306}$ На пример, како се може очекивати да ће становништво једне земље шире подржати циљеве ЕУ (или НАТО) уколико просечне особе, или чак већина људи који раде у канцеларијама државне управе, немају чак ни основне информације о ЕУ? Један од разлога за то може бити непотребна мистификација једног дела таквих информација или повремено искључивање власништва над таквим информацијама ради спровођења посебних интереса.
} 
информација не може да спречи настали јаз или да иде укорак са све већом количином информација и брзином којом настају, што је све, опет, условљено бржим променама у свету. Овде бисмо указали на потребу да се успостави „индустријализована“ подршка управљања знањем. Ова тенденција се може испољити кроз стварање мреже центара знања, као важан услов изградње инфраструктуре за јачање и развијање безбедносне културе.

Центри знања трансформишу све делове друштвеног живота. Њихов изглед и институционализација дају нови подстрек за процес развоја глобалног информационог друштва. Центри знања могу да постану катализатори исцрпних, основних друштвених промена. Можда је још важније да се успоставе већа транспарентност и обезбеђивање приступа основним информацијама за шире друштвене групе и кориснике, што ће ставити тачку на политику искључења важних информација и монополизацију информација. Захваљујући услугама центара знања, убрзава се ширење знања и јача сарадња, а све иновације у том смислу обезбедиће стварну прилику за усклађивање великих група у друштву. Јачање невладиних организација и цивилног друштва можда је најважнији аспект позитивних промена. Неполитички облици контроле власти такође су важни и тек ће се појавити нови и развијати.

Безбедносна култура као систем знања може се представити и разматрати кроз савремени, хуманистички конципиран образовни курикулум, који треба да пружи могућност да се створи општи социо-културни амбијент за подстицање остваривања и поштовања основних људских права, ненасилног понашања и развијања меких и тврдих вештина [soft skills и hard skills] за примену ових принципа у свакодневном животу.

За разлику од традиционалног курикулума, који се сводио на учење „напамет“ садржаја наставних програма, савремени курикулум усмерава се на развијање критичког духа, развијање вештина истраживања и решавања проблема, као и доношење значајних одлука за успешан живот у друштву које се брзо мења, пролази кроз кризне циклусе и у којем стечена знања брзо застаревају. Наиме, потребна су знања о конструктивним људским понашањима и вештине којима се могу предупредити штетне последице брзих промена за сваког појединца и 
за друштво у целини. Ове вештине произлазе из знања о принципима родне једнакости, људских права, о ненасиљу и из схватања зашто и како ове принципе треба бранити, развијати и примењивати у пракси. Ови принципи треба да се разматрају са свим актерима образовног процеса (и формална и неформална димензија) у контексту карактеристика тих актера, њихове уже и шире социјалне средине, владајуће религије и културних традиција.

Сва искуства, идеје и питања која се појаве треба разматрати, усмеравати и подстицати да се ставе у функцију развијања и ширења безбедносне културе, као нове манифестације знања које ће допринети опстанку, развоју и добробити. То, такође, мора подразумевати предузимање мера за већу правичност у приступу образовању (на свим нивоима) свих друштвених слојева, већи обухват образовањем, већу ефикасност и доступност образовања и, наравно, наставне планове и програме примерене потребама будућности.

\subsection{2 Безбедносна култура манифестована кроз ставове}

Безбедносна култура, као и сама култура (лишена атрибута безбедности), може да формира контекст у оквиру којег се развијају и одржавају безбедносни ставови појединца (групе или неког ширег ентитета) и промовишу разна безбедносна понашања.

Познато је да су ставови трајни системи позитивних или негативних процена, емоционалних категорија и техника за акцију про или контра према друштвеним објектима. Овај појам се схвата и као предиспозиција или ментална спремност, што имплицира да људи, поседујући ову тенденцију или мотивацију, посматрају друштво у оквиру дефинисаних категорија добра и зла. ${ }^{307}$

Посматрајући их као процес или систем, можемо рећи да појединац на основу вредности уређује своју средину и понашање. При том, ако су вредности мера

\footnotetext{
307 Бен Рејк, Кристина Едкок, Вредности, ставови и промена понашања, Нолит, Београд, 1978, стр. 26 .
} 
помоћу које уређујемо нашу друштвену средину, а ставови манифестација овог уређења, онда су они тесно повезани основном претпоставком о човековој потреби за редом и сигурношћу, што је и логично и очигледно.

Ставови, као део безбедносне културе, представљају скуп веровања о безбедносним и небезбедносним ситуацијама или питањима живота које деле чланови једног друштва или заједнице и који их предиспонирају да се у вези са тим питањима или у тим ситуацијама понашају на одређени начин. Знамо да став и понашање могу да буду у високој корелацији, али ни то није увек правило. Поступци и одлуке које спроводе чланови неких колективитета нису увек у складу са ставовима које су изградили, јер на те поступке и одлуке утичу и други фактори. Стога могу бити на делу декларативно опредељење, као став према одређеном питању, и стварно понашање у односу на исти проблем.

Безбедност се различито схвата у разним културама и безбедности се може приступити преко дивергентних ставова. Узмимо пример о поверљивости преко примера личне приватности и владиних законских норми. Став према безбедности може бити утврђен дугим развојем социо-културног обрасца, или се одредити према нормативним актима, а то смо већ видели на примеру западног начина пословања и јапанског.

Када су у питању емпиријска истраживања и када је потребно дефинисати димензије или компоненте безбедносне културе, посебно је важно испитати ставове и запажања испитаника у односу на безбедност. Број идентификованих димензија може да варира од једног до више показатеља. С обзиром на то да се сличне теме могу рефлектовати у показатељима, варијације у начину на који су разна питања презентована у упитницима могу допринети разликама у структурама фактора.

Проблем који може настати јесте да ставови који се испитују заправо представљају одраз једног другог сродног концепта, као што је безбедносна клима. Клима је много површнији концепт од културе, описује важне особине тренутног стања (унутар организације, на пример). У том контексту култура се сматра стратешком и дугорочном, а клима тактичком и краткорочном. Култура је, као што смо већ напоменули на почетку рада, у својим разноликим 
конфигурацијама, укључујући и безбедност, веома апстрактна, слојевита, стабилна, па и глобална. Самим тим су и њени показатељи мање видљиви и теже их је измерити, те је и организација истраживања и испитивања ставова у овој области веома сложена.

У неким емпиријским истраживањима везаним за различите индустрије и њихову безбедносну културу запажено је да структура безбедносних ставова често зависи од контекста. Тако су разнолики структурни фактори пронађени за различите индустрије и за различите културе.

\subsection{3 Безбедносна култура као начин понашања}

У литератури је запажено да поједини аутори већи акценат стављају на ставове, док неки други величају значај понашања и на основу тога, сагле́дање и утврђивање оквира или мере у којој је безбедносна култура присутна или не. Унутар ове перспективе безбедносна култура се посматра као оквир напомена или смерница за понашање у различитим ситуацијама, који одређује врсте прихватљивог понашања или она понашања која ће бити награђена и самим тим помажу да се обликују понашања којима се одређени актери већ рутински баве. У том смислу можемо посматрати и анализирати понашање појединца, понашање организације, државе или глобалног међународног система. Понашање, и позитивно и негативно, научено је током времена. Одређене врсте учења могу захтевати да се стално понављају извесне радње, како би се осигурало да прописане радње постану друга природа оних који се уче том понашању, односно да постану њихова рутина.

Безбедност се све више признаје као једно од оних типова понашања који треба да се науче. Ако посматрамо организациони ниво, почевши од врха (врховног менаџмента) и спуштања до нижих нивоа, мере безбедности треба да се на методски начин практикују и оснаже код свих. Безбедност је практична основа рада сваке организације, али не остварује свака организација основни циљ ефикасно обезбеђивање себе. Пре него што безбедност и потреба за безбедношћу постану део свакодневног рада свих (запослених), руководство 
мора бити уверено у вредност појачаних безбедносних мера и мора то показати такође својим понашањем.

Безбедносна култура предвиђа начин на који се појединац, група или неки други ентитет понаша у складу са поштовањем безбедносних правила и очекивања. То подразумева могућност идентификовања опасности, ризика или претње којима су изложени и могућност да се ефикасно одговори на њих. То такође, подразумева јачање групне норме ради одржавања безбедносне праксе, тако да сви учесници неког друштвеног односа подржавају једни друге у безбедносном понашању. Да би то понашање било што исправније, неопходно је исказати спремност и способност прецизног запажања, анализе и процене постојећих ризика (засновано на увежбавању задатака и учењу из искуства), али исто тако и показати мотивисаност, при чему је та мотивација заснована на утврђеним безбедносним вредностима које су општеприхваћене и пожељне.

Поштовање безбедносних мера, процедура и стандарда може бити условљено и принудом, пре свега због страха од дисциплинских мера или санкција које могу бити примењене. Наравно ту се уочавају два приступа - један заснован на контроли (који се често показује као мање ефикасан) и други који се заснива на обавезивању и подразумева продубљено поверење и ефикасно обавезивање међу актерима. Такође, истраживања показују да охрабривање организационог понашања у вези са безбедношћу зависи од безбедносне културе карактерисане осећајем припадности и овлашћења, док је обесхрабрује она која отуђује кроз присилно наметање прописа̂.

Друштвено подржавање међу сарадницима (што се рефлектује кроз висок степен групне кохезије) такође подржава развој организационог понашања у вези са безбедношћу. Веома је важно и поверење, и то не само у смислу да подређени имају поверење у менаџмент/руководство, већ и да подређени осећа како менаџмент/организација има поверења у њега (најчешће кроз овлашћења, јер учествовањем и добијањем овлашћења̂ преузимају одговорност за безбедност). 


\subsection{4 Безбедносна култура и симболичка комуникација}

Као што је у првом поглављу већ приказано, најочигледнија функција симбола јесте да означавају неке ствари. Многе симболе користимо како бисмо представили своје схватање света, као и начин на који он функционише. Такви симболи који су обично језички, повезани су путем општеприхваћених конвенција са светом који се опажа.

Употреба симбола указује на квалитативну разлику, специфичност врсте „човек“, који је у стању да се у односу према природи, као и у међуљудској комуникацији, служи симболима као новом, само људском друштву примереном формом, којима успоставља фундаментално нов однос према свету. Дакле, и рани духовни облици: језик, магија, цртежи на пећинама, племенски морал и приношење жртве, али и проналазак ватре, камене секире и точка, као и сложеније деривације, као што су митологија и филозофија, усмено предање и књижевност, изградња верских храмова, наука и техника произвођења, урбани живот људи - сви они носе поменути симболички карактер, трагове аутентичног људског стварања.

Симболи су врло ефикасан механизам комуницирања пожељних вредности и ставова, јер они делују најчешће у подсвести људи, а ти исти људи нису увек свесни оних порука које примају и усвајају док су изложени неком симболу. Осим тога, симболи најчешће изазивају и одређене емоције, те су и због тога упечатљиви, а њихове поруке се дуже памте. Симболи обухватају све оно што у колективу, друштвеној групи или организацији има неко значење за њихове сународнике, чланове или запослене. Симболе чине сви материјални и нематеријални објекти и појаве који су настали као продукт заједничких претпоставки, вредности и веровања чланова неког колектива, организације или друштвене групе.

Новије антрополошке анализе регистровале су улогу и значење конструкције, симболике и ритуала у људском друштвеном животу и самим тим указале на ново разумевање културе као значења. Симболи, дакле, обухватају све оно што у оквиру неког ентитета има значење за његове припаднике или чланове, а све 
оно што се дешава иначе је одраз културе (националне, организационе, безбедносне...) и носи печат претпоставки, вредности и веровања, које у већој или мањој мери сви деле. Симболе можемо груписати у семантичке (језичке) и симболе понашања - ритуале и материјалне симболе.

Језички симболи се преносе путем језика, односно разних језичких форми, као што су: речи, изрази, жаргон, приче и анегдоте, метафоре, митови и слично. Језиком се изражавају знање и искуство припадника културе и у њему су сублимирана значења која чине културни садржај. Ритуали су, као што је већ познато, обрасци понашања који се примењују у одређеним стандардизованим ситуацијама, при чему се слави одређена вредност или веровање, што се јасно ставља до знања учесницима и посматрачима ритуалног понашања. Упечатљиви примери из војних безбедносних структура јесу: полагање војничке заклетве, војне параде, свечана промоција нових официра и сличне манифестације.

Материјални симболи се осмишљавају и плански дизајнирају како би уобличили одређену слику и пласирали је како унутрашњој тако и спољашњој јавности. Као материјални симболи - артефакти - издвајају се форме урбанистичког уређења, монете, образовна пракса, војни кодекси, боје, униформе и одевне комбинације (професионалне, војне, полицијске), бренд (лого, web-сајт, рекламни материјал) и друге.

Многе симболе можемо пронаћи и везати управо и за комуникацију у сфери безбедности. Безбедносна култура подразумева скуп прилично фундаменталних симбола и вредности које се односе на опште разумевање карактера међународног система, природе држава и њихове улоге у међународним односима. Непознавање и неразумевање одређене симболике, било да се испољава кроз језик, понашање, ритуал или има своју материјалну димензију, доводи, у најмању руку, до неспоразума, али и до озбиљних последица у комуникацији и развијању одређеног непријатељског односа између актера. ${ }^{308}$

\footnotetext{
${ }^{308}$ Године 1957, након примирја којим је окончан рат, УН су распоредиле своје прве мировне снаге да надгледају раздвајање египатских и израелских трупа у Гази и на Синају. Прве
} 


\section{7 Методологија и модели истраживања безбедносне културе}

Код културе (самим тим и њене безбедносне димензије) и научног приступа њој отвара се питање колико су сви друштвени проблеми подобни за научно третирање и за механичко преношење методолошких искустава стечених у проучавању природе на подручје друштвених наука и где то води. У стварима које се тичу човека, инсистирањем на науци и научноме методу може се много изгубити на дубини и свеобухватности, пре свега због тога што је човеков положај у свету често представљен као „трагичан“ и што је људски живот разапет између бројних неразрешених супротности. А то значи да друштвени процеси у много већем обиму садрже у себи елемент ирационално̄г и непредвидиво̄г него што то признаје рационалистичко схватање.

У свету природних наука готово све је могуће унапред израчунати и предвидети, али је у људском друштву то ипак немогуће, јер би у супротном значило не уважити оно што је човеку најсвојственије и што историју људског друштва чини историјом у правом смислу речи, презриво се опходити према ономе што човека и његов свет битно одваја од свих осталих ствари и појава у природи.

Више пута је већ потврђено (у науци, али и ван ње) да оно што хоћемо да сазнамо када се интересујемо за човека и друштво далеко превазилази границе онога што је наука у стању да одговори. Истраживаче интересује не само начин на који се успостављају, одржавају и мењају друштвени односи, већ и унутрашња, смисаона страна тих односа, природа и укорењеност (прожетост) тих односа у додирним вишим и нижим слојевима стварности. Такође,

вечери када су снаге УНЕФ-а биле распоређене у појасу Газе, војници УНЕФ-а су отворили митраљеску ватру на минарет, са којег је верски вођа позивао вернике на молитву. Припадници снага УН, не схватајући исламске обичаје и ритуале, ово су разумели као позив на грађанске немире. Ово је само један у низу примера како се непознавање и неразумевање друштвених и културних динамика група у сукобу, негативно одражава и на успех мировне мисије, а таквих неуспеха је, нажалост, у историји ОУН било више. 
интересује их питање вредности и оправданости постојећих друштвених установа с обзиром на човека и могућност остварења највиших и најплеменитијих људских способности.

Концепт безбедносне културе може да представља изазов истраживачима, са многим идејама и могућностима за занимљиво истраживање, међутим, до сада је већина дебата у овом пољу спроведена на концептуалном и теоријском нивоу. Један од разлога може бити чињеница да културалне променљиве није лако дефинисати и измерити. Више примењених истраживања у овој области спроводило се применом концепта стратешке културе. Наиме, као што смо већ назначили, стратешка култура је анализирана као цивилизацијски феномен западни начин ратовања, као и међународне институције и норме, затим као стратешка култура појединих држава и однедавно као стратешка култура међународних организација.

Иако је стратешка култура повезана са коришћењем војне силе, најновија истраживања о стратешкој култури не ограничавају се на анализу војних фактора и тежи да истражи како културна средина утиче на понашање државе у целини. Самим тим се ширењем поља истраживања све више приближава концепту безбедносне културе. Сматрамо да концепт безбедносне културе има више референтних оквира, који дају читав спектар могућности са солидним полазним основама за развијање другачијих методолошких искустава.

\subsection{1 Приступ са аспекта организационе културе}

Да би постигла ма коју сврху, досегла ма који циљ, људска бића се морају организовати. Организација подразумева врло одређену схему или структуру, чији су главни чиниоци универзални по томе што су применљиви на све организоване групе, које су, опет, у својим типичним облицима универзалне широм човечанства.

С обзиром на то да постоји извесна нејасноћа око појма безбедносне културе и прихватљивог објашњења како тај појам ,,ради“, у досадашњим истраживачким подухватима углавном се полазило од оквира организацијске културе. Овај 
оквир за сада пружа сасвим довољно елемената за развијање модела истраживања безбедносне културе.

Истраживања о безбедности у организацијама традиционално су углавном фокусирана на следеће аспекте безбедности: развој безбедносне политике, ${ }^{309}$ едукацију запослених ${ }^{310}$ и обезбеђивање подршке овим иницијативама од стране менаџмента. ${ }^{311}$ Иако су ови аспекти важни, многе организације не спроводе одговарајуће безбедносне политике. Ако су и прихватиле, оне сматрају да ће, без организационе културе која би подржала њихов развој, спровођење ове политике кроз традиционални циклус свесне обуке и складног тестирања вероватно бити слабије од оптималног.

Први корак у препознавању безбедносних ризика иде управо у правцу стварања безбедносне културе. Само зато што се безбедносно окружење мења, не постоји гаранција да ће се безбедносна култура одржати/развити или да ће организација одмах уградити безбедносна питања у свом свакодневном раду. У свим организацијама, а посебно оним где је развијена и обимна бирократија, културне промене се не дешавају лако или брзо. Успешна промоција безбедносне културе зависи од неколико кључних фактора. Свако лице које се бави безбедношћу организације односно корпорације мора водити рачуна да расправља о случају безбедносне културе на убедљив и кредибилан начин. Континуирана процена безбедносног система, као и способност да се предвиде перформансе система наспрам промењеног сценарија, функција је коју може обављати једино особље које је и са́мо прожето безбедносном културом.

У том смислу, безбедносна култура налаже не само техничку стручност кадрова који су директно и индиректно укључени у безбедност, већ и њихову вољу и мотивацију да следе утврђене поступке, у складу са прописима, и да преузму иницијативу када настану непредвиђене околности, као што ће, с

\footnotetext{
${ }^{309}$ C. Wood (2000), „Integrated Approach Includes Information Security“, Security 37 (2), $43-44$.

${ }^{310}$ E. Freeman (2000), „E-Merging Risks: Operational Issues and Solutions in a Cyberage“, Risk Management 47 (7), pp. 12-15.

${ }^{311}$ S. Hinde (1998), „Recent Security Surveys“, Computer and Security 17 (3), 207-210.
} 
обзиром на ограничења људског визионарства и инвентивности, то урадити у односу на противника са којима се суочавамо данас.

Безбедносна култура омогућава да се на деловање познатих и неодређених безбедносних ризика пре одговори пажљиво подешеним и проактивним навикама него импровизованим напорима. С тим у вези је неопходно да запослени разумеју потребу за већом безбедношћу, а важно је да и руководство покаже како је у њиховом најбољем интересу да се о безбедности озбиљно разговара и размишља. Такође је важно помоћи им да виде где се безбедносна култура уклапа у управљање ризицима. И потребно је да људи схвате како безбедност помаже да се посао заврши, уместо да се стане на пола пута.

Ако запослени не виде да врховни менаџмент доноси јасне изјаве и показује да је безбедност приоритет, неће га ни третирати као приоритет. Ова очекивања се односе како на виши тако и средњи менаџмент, вође тимова и супервизоре где свако треба да прати исту праксу безбедности и процедуре. Јер, ако менаџери не доживљавају озбиљно безбедносну политику или процедуре, ни запослени неће те политике узети озбиљно.

Разумевање, а затим и развијање безбедносне културе у организацијама у којима је безбедност кључни фактор успеха - вероватно ће допринети да те организације буду више у стању да остваре своје примарне циљеве и одрже своју репутацију. Ово је нарочито важно за организације које за безбедност (националну посебно) пружају критичне производе и услуге (енергија, хемијски производи, храна, вода и слични ресурси), организације које раде са људима и местима препуним људи (аеродроми, транспортне мреже) и оне које су подложне ризицима од преваре, крађе или шпијунаже (као што су организације у области финансија), као и организације из ужег безбедносног сектора.

\subsection{2 Приступ са аспекта супкултуре/-а}

Сва досадашња друштва, са изузетком раних, „примитивних“ заједница, била су значајније диференцирана и стратификована, тако да се и култура у таквим 
друштвима диференцирала. Тако је и данас - уместо јединственог система културе, имамо посла са више врло различитих поткултура (поткултуре слојева и класа, поткултуре одређених друштвених група, признатих и непризнатих, свака породица такође на свој начин представља једну својеврсну културу, а може се говорити и о поткултурама генерација, што је данас у већој мери основ диференцирања културе него са̂м класни елемент). ${ }^{312}$

Култура, као перманентни процес, нужно се диференцира и на елементе традиционално̄г и савремено̄г. Дакле, разни елементи културе налазе се у различитим односима према друштвеном систему: поједини елементи културе интегрисани су у друштвени систем и њему подређени (вршећи функцију система); други су релативно независни, али не излазе из оквира система и нису са њим у сукобу; трећи, у покушају да превазићу постојећи систем, најчешће долазе у сукоб са нормама друштва и вредностима.

У коликој ће мери који елементи културе бити у сукобу са њим, зависи не само од потреба система, његових циљева и могућности да се помоћу елемената културе остварују циљеви и задаци политике, већ и од усмерености саме културе и од тога колико је вредносна оријентација културе у складу или у раскораку са вредносном оријентацијом друштвеног система. Разлике и истоветности могу да буду толико дубоко укорењене у наш говор и мишљење о свету, било због њихове улоге у нашим практичним животима или зато што су сазнајно моћне и представљају важан аспект начина на који осмишљавамо своје искуство, да сваки теоријски изазов према њима може изненадити. ${ }^{313}$

Као што има неких универзалних елемената безбедности, постоје и извесне врло посебне безбедносне бриге које проистичу из структуралних локација различитих група у оквиру друштва и између народа/нација. Као што смо приметили и у погледу социолошког приступа безбедности, различити структурни елементи једног друштва имају сопствено виђење безбедности, она

\footnotetext{
312 Загорка Голубовић, Антропологија, Службени гласник, Београд, 2007, стр. 60-61.

${ }^{313}$ John Mepham, „The Structualist Sciences and Philosophy“, in: D. Robey (ed.), Structuralism: The Wolfson College Lectures 1972, Cape, 1973; према: Дик Хебдиџ, „Поткултуре - значење стила“, у: Студије културе, Зборник, Службени гласник, Београд, 2008.
} 
је део њиховог начина живота, егзистенције и свих свакодневних активности којима себи обезбеђују напредак и развој. То је уједно и нека врста амбивалентног квалитета безбедности, што понекад може представљати проблем за аналитичаре и творце политике.

Руководиоци националне безбедности често претпостављају да ће њихове одлуке, које имају благотворне ефекте на међународном плану, аутоматски побољшати безбедност државе, друштва и појединца. Да није баш тако, увиђа се када грађани почињу да постављају питања како ове одлуке генеришу сигурније везе, више међузависности и чвршће стварне заједнице у земљи, али и у иностранству. Важно је, дакле, уважити скептичне, уске, сумњичаве и ексклузивне ставове о безбедности чија се потраживања генерализују узимајући у обзир оба пола, све друштвене групе, свих грађана и народа/нација који живе на том простору.

Безбедност мора бити довољно широко дефинисана да обухвати различите начине на које појединци и групе настоје да побољшају своју безбедност, а ипак довољно уска да обезбеди нормативни критеријум којим се процењује да ли ће намеравана акција заиста унапредити безбедност.

У сваком случају, људи, организације и системи морају бити свесни да супкултуре постоје и делују. У складу са тим неопходно је прилагодити методолошки апарат потребама и разликама у потреби и интересу за безбедношћу које испољавају одређене друштвене групе. Сматра се да су организационе диференцијације у супкултурама у средишту друштвених структура и моћних односа, који могу да утичу у смислу конструкционо различитих верзија реалности. Права култура је неопходна да би безбедносни системи функционисали, а због тога што је култура у специфичном односу са групама, организације могу повећати број посебних култура и супкултура.

\subsection{3 Приступ са аспекта социјалног и/или културног капитала}

Социјални капитал се може објаснити као способност која настаје из преовладавања односа поверења у друштву или у одређеним његовим 
деловима. Ови односи могу бити на делу у базичној друштвеној групи, породици, као и у највећој од свих група, нацији, али и у свим другим групама које се налазе између ове две. Социјални капитал се разликује од других облика људског капитала утолико што се обично ствара и преноси помоћу културних механизама, као што су религија, традиција или историјски настали обичаји.

Социјални капитал се односи на капацитете појединаца и њихову способност да обезбеде одређене погодности кроз чланство у друштвеним мрежама и другим друштвеним структурама. Култура се може посматрати као инструмент који промовише кохезију кроз стварање заједничког језика, на тај начин припремајући сцену за социјално вођен развој људских потенцијала, стварањем или регенерацијом друштвеног ткива и уопште оптимално управљање акумулацијом процеса за друге кључне нематеријалне облике имовине, као што је друштвени капитал, са последичном коришћу у смислу унапређивања друштвеног поретка и кохезије.

Стицање социјалног капитала постиже се навикавањем на норме заједнице којој се припада и стицањем врлина, као што су лојалност, часност и осећање међузависности. Група као целина прихвата заједничке норме пре него што се међу њеним члановима генерализује поверење. Социјални капитал је заснован на доминацији социјалних, a не индивидуалних врлина. Склоност ка социјабилности се стиче много теже него друге форме људског капитала, јер је пре свега заснован на етичким обичајима, а самим тим га је теже мењати или разбити.

Социјални капитал, који је у својој основи и културни капитал, мора да испуни неке од услова да би био у служби безбедносне културе, а пре свега: да обезбеди боље управљање, побољша руковођење заједничким ресурсима, да рашири информације и подстакне иновације и да служи као неформална социјална безбедносна мрежа.

Као веома важну компоненту или елемент социјалног капитала можемо размотрити „секуритабилност“, која се може дефинисати као способност појединца да избегава небезбедне ситуације и да задржи осећај безбедности када дође до таквих ситуација, као и способност да поново успостави своју 
безбедност и уједно свој осећај безбедности када они постану дискутабилни. Иако је појам „секуритабилност“ и у нашем и у енглеском језику тешко превести дословно, њен смисао је релативно јасан: постоје две међусобно повезане димензије - објективно стање безбедности и субјективни осећај безбедности. У зависности од тога да ли особа поседује висок или низак ниво безбедносног потенцијала (капацитета), она може да перципира дату ситуацију било као прилику која јој се пружа, као сигнал упозорења да спречи или избегне ризик, или као са̂м ризик. ${ }^{314}$

Појединци који поседују висок степен безбедносног потенцијала могу да самостално, или унутар породице, локалне заједнице или државе, раде на одржавању и повећању своје безбедности. Њихов осећај безбедности може повремено бити уздрман, али и то траје само привремено. Чак и када тога нису свесни, они користе вештине управљања ризиком како би превазишли потешкоће и решили проблеме. Они се ослањају на поуке које су извукли и развијају „своју безбедносну стратегију“, како би поново стекли субјективно осећање и објективно стање безбедности. ${ }^{315}$

Неки сегменти социјалног капитала који нарочито доприносе развоју безбедносног потенцијала појединца, групе или неког другог ентитета јесу:

a) Способност умрежавања - успостављање и одржавање неформалних друштвених веза у групама као што су породица, пријатељи, колеге, комшије и сличне особе представљају важан извор безбедности за многе појединце. Постоји велики потенцијал формалних мрежа, као што су HBO, у смислу помоћи многим грађанима да повисе свој ниво безбедности. Способност умрежавања је битна за НВО и друге формалне организације и она мора константно јачати. Од већег учешћа

\footnotetext{
${ }^{314}$ United Nations Development Programme, Latvia Human Development Report 2002/2003: Human Security, Riga, Latvia, 2003, pp. 15, 19.

315 Видети више о томе: Драгана Дулић, Светлана Станаревић, Весна Николић, Cтање и периепииа људске безбедности у Србији - ка успостављању индекса људске безбедности. Извештај за 2008. годину, Фонд за отворено друштво, Београд, 2010.
} 
у активностима локалне заједнице може да има користи много људи, нарочито ако знамо да тиме јачају свој безбедносни капацитет.

б) Спремност да се укаже поверење и развије сарадња са државним и међународним организацијама. Људи морају веровати како њихова влада истински намерава да испуни своју улогу у заштити безбедности (појединаца, друштвених група и друштва/државе у целини), као и да има капацитет за то. Овај капацитет се одражава у њеној способности да оствари добро формулисане циљеве и испуни свој мандат, како на домаћем, тако и на међународном плану.

\subsection{4 Хуманолошки приступ}

Позивајући се још једном на постулате Дилтајеве филозофије, морамо нагласити тврдње које указују на повлачење границе између физичког света и историје, а при том знамо да историју сачињавају људска бића и тај њихов људски свет обележен је значењима. Односи у људском свету нису просто каузални, већ су смисаоне природе, што подразумева нове категорије, као што су: симболи, вредности, сврсисходна активност, слобода. С друге стране, ни историјски живот није проста датост, него перманентна креација, стално произвођење нових добара и вредности, па се мора схватити и са аспекта активности. Због тога прави предмет проучавања нису чињенице као нешто са́мо по себи постојеће, већ „креације духа“, дакле, целокупна култура изражена у језику, обичајима и свим другим формама духовне производње које најпотпуније изражавају живот. ${ }^{316}$ Дилтај је заменио инертну стварност, схваћену у смислу физичких чињеница и објеката, „системом интеракција“, тј. системом односа који се схвата као „узајамни однос који се испољава у трајним креацијама“, изражавајући вредности и реализујући циљеве.

Историјско објашњење се заснива на антрополошким сазнањима о човеку, при том историја као наука о животу мора бити у стању да ступа у однос са

${ }^{316}$ W. Dilthey, Meaning in History, G. Allen and Unwin, London, 1961; према: Загорка Голубовић, Антропологија, Службени гласник, Београд, 2007, стр. 166-167. 
животом и такво проучавање се назива хуманистичким. Хуманистичка наука има циљ да објективизацијом живота кроз резултате људског стваралаштва схвати унутрашњу природу историје. То је херменеутика, која проучава „све оно на шта је човек својом активношћу ставио печат“, а такав приступ претпоставља установљавање односа између спољашњег и унутарњег света.

Из свега овог произлазе и посебни методолошки захтеви, које је Дилтај формулисао као метод разумевања, заснован на способности саосећања са резултатима људског стваралаштва у историји и са вредностима различитих историјских епоха. Разумевање нас доводи до научних резултата само ако нас премешта од уског субјективног искуства ка општем и универзалном, на чему се заснива разумевање односа̂ у људском свету. Разматрајући и Веберову „разумевајућу“ социологију, уочава се покушај социолога да схвате како групе у различитим културама и епохама, као и у различитим пољима социјалног деловања - привреди, религији, политици или уметности - стварају смисао свог живљења.

Тако и интерес за безбедношћу настаје у условима у којима је човек свестан смисла односно бесмисла свог постојања, и то кроз своју отворену структуру у оквиру које управо артикулише интерес безбедности. То пре свега подразумева посматрање човека, односно људског бића као бића које у темељу својих природних својстава третира безбедност као динамичан феномен, који својим „поривом“ за променом конституише и развија то исто људско биће. Да бисмо утврдили како наступа стање безбедности, које је заправо специфично стање хуманитета (као начин сагле́дања „света људских ствари“), неопходна је продубљена анализа.

Према М. Бодину, она се реализује кроз, условно речено, три димензије: фундаменталну, прагматичку и техничку. ${ }^{317}$ Анализа фундаменталних својстава обухватила би моделе конституције нације, безбедносне интересе и критеријуме остваривања националне безбедности. Анализа прагматичких

317 Бодин, Миленко, „Теоријске претпоставке разумевања и остваривања националне безбедности“, у: Ризик, моћ, заштита. Увођење у науке безбедности, Службени гласник и Факултет безбедности, Београд, 2010. 
својстава: артикулацију националних интереса, начине формулисања интереса националне безбедности и аспекте остваривања интереса националне безбедности. Коначно, анализа техничких својстава обухвата начине институционализације националне безбедности, организацију посебних институционалних сегмената и дефинисање програма и послова унутар установа од значаја за националну безбедност.

У методолошком смислу, оваква анализа изискује огроман напор да се прецизно дефинишу параметри и утврде подесан методолошки апарат и инструменти, али ни у којем случају не сме бити фактор који ограничава могућности и способности истраживача да се ухвате укоштац са проблемима који из тога произлазе. Циљ хуманолошког приступа истраживању безбедносне културе мора да буде развој људског потенцијала, хуманизација и досезање виших нивоа људског развоја.

\section{8 Развој и примена концепта безбедносне културе}

\subsection{1 Приступ заснован на образовању}

Развој и примена концепта безбедносне културе заснован на образовању подразумева пренос и неговање знања, способности и специјализованих вештина, формирање ставова, као и проширење хоризонта индивидуалности. Као и друге друштвене институције, формалне институције у области образовања и васпитања имају манифестне и латентне функције. Међу манифестним функцијама налазе се, на пример: пренос и учење (страних) језика, математичке и природне науке и знања у областима економије, географије, историје и права. Међу латентним функцијама се наводе културни кодови, одржавање друштвене контроле и друштвене хијерархије, као и промовисање друштвене интеграције.

Како се наводи у литератури која се бави овом проблематиком, у току је историјски покушај да се изгради нови скуп образовних пракси, као одговор на 
превирања и насиље, и самим тим забринутост за безбедност. У том контексту је и идеја индивидуалног субјекта, којим се калкулисало у материјалном контексту, била део повезаног низа практичних трансформација, покушај да се реартикулише и идентитет и епистемологија у служби нових друштвених пракси које воде ка миру и грађанском реду.

Живимо у времену када настају иновације и продори и у самим техникама за извођење културолошких истраживања о питањима мира и безбедности. Образовне, а посебно високошколске институције морају бити део ширег таласа интересовања за културна истраживања и питања конфликта и других проблема у области безбедности. Озбиљан напредак у превазилажењу културних баријера у изазовима глобалног управљања могућ је ако се изврше промене од културног образовања до културолошких истраживања, као и ситуационог нацрта и локалних акција. Ово је потребно урадити са посвећеношћу, стручношћу, креативним искоришћавањем ресурса којима се располаже, и показати то кроз моделовање, симулацију, експерименте и ратно играње. Дакле, нови проблеми, нови параметри, нове мере, нови модели и, коначно, нови приступи развијању и примени безбедносне културе.

Стечена знања и вештине морају бити применљиви и употребљиви у привредном и практичном животу, они представљају богатство свих припадника једне заједнице и, као заједничка вредност, служе на корист целе заједнице.

\subsection{2 Приступ заснован на обавезивању}

Договор, који се постигне у неком односу, да се обавља одређена делатност и у одређеном тренутку у будућности, у одређеним околностима, може се свести под значење израза обавезивање. Обавезивање често прати посвећеност и може укључити више ствари. Прва и најосновнија је посвећеност скупу вредности, принципима или веровању. Ово опредељење подразумева постојање визије и сврхе зашто се нешто ради или не ради. Следећа ставка се односи на снажан осећај интегритета и самопоуздања, што подразумева и стално 
самоусавршавање, а такође одлучност и упорност у раду да се започето заврши, да се заврши на најбољи могући начин. Важна је подршка и могућност да се поправи, односно побољша крајњи учинак, да се посвећеност постави на један виши ниво, спремност да се тражи и да се нађе бољи начин да се реши проблем.

Уз мотивацију, посвећеност се све више разматра као критичан фактор успеха за имплементацију знања у систем управљања (предузећа, на пример). У теорији постоји све више доказа да је посвећеност запослених на радноме месту вишедимензионална и да ако се пажња усмери на темеље посвећености, могу се побољшати предвиђања о намерама и понашању запослених.

Према најранијим истраживањима и аутору Келману, постоје различити мотивациони процеси у основи појединачних ставова који прате посвећеност. $^{318}$ Стога Келман наводи: поштовање, идентификацију и интернализацију. Поштовање се јавља када су ставови и понашања усвојени у циљу добијања одређене награде или избегавања одређене казне. Идентификација наступа када људи усвоје ставове и понашања у циљу да буду повезани са задовољавајућим, самоодређујућим односом са другом особом или групом. Интернализација се збива када људи усвоје ставове и понашања, иако њихов садржај на почетку није подударан са њиховим вредносним системима, али то временом постане.

На сличан начин можемо посматрати обавезу или посвећеност као конструкт који се налази у основи одржавања односа између држава на међународном плану. Занимљив је пример у оквиру међународног правног режима који се развијао након Првог, а нарочито након Другог светског рата, као најамбициознији напор у историји за усвајање нових међународних правних стандарда за људска права. Иако су се, под утицајем историјских околности, владе први пут сложиле, под окриљем ОУН, око нацрта споразума да се смање могућности таквих трагедија у будућности, закључак о развоју успешног

\footnotetext{
${ }^{318}$ H. C. Kelman, „Interests, relationship, identities: Three central issues for individuals and groups in negotiating their social environment“", in: S. T. Fiske, A. E. Kazdin \& D. L. Schaster (eds.), Annual Review of Psychology (vol. 57, pp. 1-26), Palo Alto, CA Annual Reviews, 2006.
} 
правног режима био је преурањен. Све разгранатији систем уговора које је требало ратификовати примљен је са одређеном дозом резерви. Наиме, појавила се могућност потенцијалних ризика - да се обавеза која се преузима и посвећеност испуњењу ставки из уговора у будућим околностима тешко може реализовати.

У складу са тим, јавља се неколико групација влада које су разнолико одговориле и приступиле ратификацији тих споразума. Једну групу су чиниле оне земље које су искрено ратификовале и вредновале садржај уговора, те самим тим очекивале поштовање за учињено. Другу групу су представљале државе које су начелно прихватиле садржај уговора, али их коначно ипак нису ратификовале (један од новијих примера јесу и САД и њихов однос према Споразуму из Кјота који нису ратификовале, као и Конвенцију о правима детета). Последњу групу су сачињавале државе које су га ратификовале, размишљајући стратешки и рачунајући да ће трошкови бити минимални, а урадиле су то и да би избегле критику, или да би се додвориле домаћој или међународној публици. Поштовање кредибилних обавеза је тежак проблем за државе у анархичном међународном систему. Међутим, поштујући вредности и институције, управо развијене демократске државе треба да буду пример како се побољшањем својих способности одржавају међународне и сваке друге обавезе. Безбедносна култура као део институција, део културе, део демократских структура, управо то и наглашава.

\subsection{3 Приступ заснован на контроли}

Друштво је само изузетно и у извесним приликама регулативно, а закон није исто што и друштвени поредак. У једноставнијим хомогеним културама колективна навика или обичај могу да потпуно замене потребу за установљавањем било какве званичне законске власти. Амерички Индијанци су умели да кажу: „У старо време није било сукоба око ловишта или места за риболов. Онда није било закона, те је свако чинио оно што је право.“ Тај начин изражавања јасно показује како они у свом ранијем животу нису сматрали да су били потчињени неком друштвеном надзору који им је наметнут споља. Чак 
ни у нашој цивилизацији закон није ништа више до грубо друштвено оруђе, и то такво које је прилично често потребно обуздавати у току његовог осионог живота. И никада га не треба изједначавати са друштвеним поретком. ${ }^{319}$

У сваком друштву кроз густу мрежу власти и ауторитета (и институција) намећу се принуде, забране или обавезе. Да ли се и како оне испуњавају, проверава се одређеним успостављеним системом контроле. Контрола се може објаснити као свесна људска делатност коју чини упоређивање постигнутих резултата са намераваним односно очекиваним исходом. У том смислу, како наводи Љубомир Стајић, контрола се састоји од посматрања и оцењивања туђе делатности, и то према раније утврђеним мерилима, након чега, уколико постоје одступања, може доћи до одређене интервенције корективног карактера, како би се отклонио недостатак, мада исход контроле може бити и само репресиван. ${ }^{320}$

Када је реч о контроли, запажамо неколико сегмената које је важно раздвојити, који је ниво контроле, шта је предмет контроле и, на крају, начин контроле. Ниво контроле подразумева постојање целине и постојање појединих делова. Предмет контроле могу бити значењски елементи понашања, али их је тешко уједначити и униформисати, па се зато пажња пре указује економичности, ефикасности, унутрашњој организацији као показатељима снаге и успешности или неуспешности. Начин контроле подразумева непрекидну сталну принуду, надзор над разним видовима активности, а не само над њеним резултатима.

Контрола се може остварити наметањем одређених културних вредности, веровања и норми понашања запосленима или подређенима, са позиције ауторитета. Када већина запослених прихвати те вредности и норме, и усвоји их као своја лична правила мишљења и понашања, онда и контрола њиховог понашања постаје једноставна.

\footnotetext{
${ }^{319}$ Рут Бенедикт, Обрасии културе, Просвета, Београд, 1976, стр. 270.

320 Љубомир Стајић, Контрола полищије и служби безбедности, Правни факултет Универзитета у Новом Саду, 2012, стр. 19.
} 
Некада су организациона и безбедносна култура снажнији механизам контроле понашања запослених у односу на формалне прописе или директан надзор од стране руководилаца. Преко културе се покушава постићи не само контрола понашања, већ и мишљења и осећања запослених, што, морамо признати, није лако и не успева увек (мада је, на орвеловски начин посматрано, ипак могуће). У снажној култури контрола понашања долази изнутра и није потребна спољна контрола, која је увек скупа и неефикасна (тада можемо говорити и о самоконтроли на начин на који смо то представили у одељку о култури као исходишту безбедности). Када запослени прихвате снажну културну вредност да не треба „поткрадати“ предузеће, онда можемо бити сигурни да они то неће учинити.

Да би се развила квалитетна безбедносна култура, значајан акцент се мора ставити на дугорочну посвећеност или обавезивање, као и на стратешко управљање, а не само на контролу. Безбедносна култура је знатно више од објеката и процедура, реч је о стварању отвореног поверљивог окружења које је фокусирано и проактивно према смањењу ризика за добробит свих.

\subsection{4 Приступ заснован на примени стандарда̂}

Поверење је важно и потребно, у области безбедности посебно, али се не можемо увек ослонити на то. У области безбедности и развоја безбедносне културе установљени су стандарди као покушај да се одређени безбедносни поступци униформишу и успоставе као мерило њихове поузданости, ефикасности и доследности.

Стандарди, као што знамо, у великој мери имају позитиван утицај на већину аспеката наших живота. Они обезбеђују жељене карактеристике производа и услуга, као што су квалитет, позитивно деловање на животну средину, безбедност, поузданост, ефикасност. Стандарди се уводе у разним секторима: образовање, енергија, безбедност хране, безбедност информација, аутомобилска индустрија и слични. Посебна категорија су стандарди у области 
безбедности, везани за рад одређених структура како на унутрашњем тако и на спољашњем плану (међународни стандарди).

Стандарди, иначе, представљају договорен и поновљив начин да се нешто уради. Они подразумевају одређене техничке спецификације или друге прецизне критеријуме, с циљем да се доследно користе, као што је то по правилу смерница и дефиниција. Стандарди помажу да се живот учини једноставнијим и да се повећа поузданост и ефективност у обављању различитих послова и активности. Они се често намењују за добровољну употребу и не намећу се никаквим прописима.

Међутим, закони и прописи се могу односити на одређене стандарде и морају обавезно бити усклађени са њима. Сваки стандард је резултат колективног рада. Државне институције, истраживачке организације, одбори (произвођача и потрошача или корисника услуга) и други субјекти заједно делују на изради стандарда, који еволуирају идући у сусрет захтевима друштва и технологије. ${ }^{321}$ Стандарди су важни у свим областима живота и рада, али су посебно значајни у области безбедности, и то: безбедносним агенцијама, полицији, војсци,

${ }^{321}$ Постоји више врста стандарда и у различитим областима. Можемо издвојити једну поделу која обухвата: 1. стандарде спещификаиије (стандард који дефинише детаљне услове, да буду задовољни корисници производа, материјала, процеса и услуга или система, као и процедуре за проверу усаглашености са овим захтевима), 2. методолошке стандарде (стандард који даје комплетан извештај о начину на који се обавља делатност - и, где је то прикладно, опреме или алата потребних да се изврши - и закључци који се односе на степен прецизности који одговара наведеном циљу), 3. водиче стандарде (стандард који даје широке и опште информације о предмету, уз основне информације где је то примерено), 4. речник (стандардни попис дефиниција и термина који се користе у одређеном сектору, области или дисциплини), 5. кодове праксе (стандарди који садрже препоруке за прихваћене добре праксе, као што следи, од стране надлежних и савесних практичара, а које обједињавају резултате практичног искуства и стечених знања ради лакшег приступа и коришћења информација), 6. стандарде класификаиије (стандарди који садрже ознаке и описе различитих разреда производа и који идентификују и организују податке у хијерархијском редоследу). Видети: www.bsigroup.com/standards. 
царини, и другим секторима. ${ }^{322}$ Заправо, први стандарди везани за област безбедности сачињени су у оквиру корпоративне безбедности и царине, нарочито након почетка ширења Европске уније. Наиме, многе земље ЕУ су своју обавезу контроле граница препустиле, у складу са Шенгенским споразумом, спољним земљама Уније и због тога су хтеле да стандардизацијом безбедносних поступака, метода и средстава одрже и повећају своју безбедност.

Међу значајније, када је војска у питању наводе се НАТО-стандарди. Они уређују односе између држава чланица, али и свих других држава партнера које учествују у евро-атлантским безбедносним интеграцијама. Примена НАТОстандарда је и војни услов за учлањење неке државе у ову организацију. НАТО-стандарди представљају запис о договору између неколико држава чланица или свих, којим усвајају исту или сличну војну опрему, наоружање, муницију, системе снабдевања и складиштења, као и оперативне, логистичке и административне процедуре. ${ }^{323}$

На нивоу ОУН такође се користе стандарди, а међу новије свакако спадају Минимални оперативни безбедносни стандарди (MOSS). ${ }^{324}$ Настали су као потреба да се успоставе стандардна поља на бази минимума критеријума за безбедносне аранжмане, како би се унапредила безбедност на терену,

322 Једна од важних тема које покривају стандарди, када су у питању ове институције, може бити и безбедносна провера будућих запослених за многе положаје у владиним безбедносним структурама, која, између осталог, подразумева проверу отисака прстију и полиграфско тестирање. У сваком случају, важно је да стандарде прате и законски и подзаконски акти. Запослени у безбедносним структурама морају да добро познају закон, те, поред осталог, када је дозвољена употреба силе, знати како да правилно користе различита средства силе, укључујући и ватрено оружје. Императив у безбедносним структурама гласи да само стручњаци са високим нивоом знања о различитим законима могу постати чланови тима. Постављањем коректних и правних стандарда смањује се вероватноћа да се уради било шта незаконито.

${ }^{323}$ НАТО-агенција за стандардизацију: htpp://nsa.nato.int/

${ }^{324}$ Towards a Culture of Security and Accountability, The Report of the Independent Panel on Safety and Security of UN Personnel and Premises Worldwide, 2008. 
ублажили ризици и омогућило извођење операција. Водич за MOSS је објавио Савет безбедности УН и он описује мере које се могу применити у целини или делимично, у зависности од безбедносних потреба датог радног места.

Он је дефинисао одговорност за менаџере у седишту агенције (УН) и на терену, те као такав подлеже одговорности. MOSS је добро прихваћен и разумљив, а током година је и оплемењен уз пораст стандарда безбедности, посебно као одговор на терористичке претње. Током рада на терену уочена је важност планова за медицинску евакуацију и пружање медицинске помоћи. Показало се да је неопходно развијати хитне медицинске тимове, здравствене установе у угроженим областима, а као приоритети које је потребно обухватити стандардима наводе се медицински захтеви за болничаре, прву помоћ и спецификацију захтева̂ медикамената.

У нашој земљи се у новије време развијају стандарди у области друштвене безбедности, који покривају област континуираног управљања кризним ситуацијама помоћу техничких, људских, организационих, оперативних и управљачких приступа. Први српски стандарди утврђују захтеве за услугама приватног обезбеђења. ${ }^{325}$

Примена стандарда̂ представља саставни део рутинских послова сваке организације. Да би се ефикасно процениле безбедносне потребе (организације) и вредновали различити изабрани производи и безбедносне политике, неопходно је на систематски начин дефинисати услове за безбедност. Они морају бити усаглашени на свим нивоима деловања и рада државних и друштвених институција, организација и појединаца.

Као неки од најважнијих стандарда за сваку организацију наводе се стандарди у области безбедности информација и информационих система. ${ }^{326}$ Овим стандардима се дефинишу обим безбедносних функција и могућности, потребне политике за управљање информацијама и људским средствима, критеријуми за оцену безбедносних мера, регулисање безбедносних обавеза и

\footnotetext{
${ }^{325}$ Институт за стандардизацију Републике Србије, www.iss.rs.

${ }^{326}$ Као један од најпознатијих стандарда у овој области фигурише стандард ISO 17799.
} 
потреба, контроле на свим нивима, технике за процену безбедности и процедуре за бављење безбедносним неуспесима, као и реаговање у кризним ситуацијама. 


\section{5 ЗАКЉУЧНА РАЗМАТРАЊА}

Модерна друштва су друштва бројних промена, а време између тих промена представљено је све краћим интервалима. То су, дакле, друштва где се услови под којима делују његови припадници мењају брже него што је потребно да се начини деловања консолидују у навике и рутине, а то је оно што је Зигмунт Бауман назвао „флуидни живот“. ${ }^{327}$ Стална променљивост утиче на промену оквира социјалног, политичког или економског живота, често стварајући збуњеност и конфузију. Због немогућности да се успори овакав темпо промена, а такође изврше предвиђање или контрола смера промене, тежиште људске активности ставља се на оне моменте на које се може утицати или за које верујемо да их можемо мењати. Свакодневно се трудимо да прорачунамо и минимизујемо ризике од небројених и недефинисаних опасности које могу угрозити нас лично или наше најближе, а које носи са собом прилично неизвесна будућност.

Постоји читав спектар рањивости што лебде над нашом планетом, која је иначе чврсто обавијена мрежом људских међузависности и где не постоји ништа што други раде или могу урадити а што не утиче и на нашу будућност. Због тога се и савремена интелектуална мисао налази пред бројним изазовима при тражењу решења за излазак из лавиринта све заоштренијих противречности и евидентних проблема који су значајно нарушили безбедност и сигурност појединца, друштвене групе, друштва и државе. Озбиљан изазов свакако представља и начин на који бисмо се прилагодили променама којима обилује савремено друштво.

У теорији се развијају различити концепти, који могу бити солидна полазна основа и препорука како да се кроз политичке и практичне токове развију механизми и средства да се ти проблеми реше на најуспешнији и најефикаснији начин. Иако смо у раду више пажње обратили на могуће поставке о томе како

327 Зигмунт Бауман, Флуидни живот, Mediterran Publishing, Нови Сад, 2009. 
се конституисао и развијао концепт безбедносне културе, неопходно је, макар и у овом делу рада, више указати на потенцијал који овај концепт носи и који се може употребити да се на нов начин приступи безбедности и безбедносним проблемима. У том смислу, ово је рад који је покушао да интегрише више елемената и концепата, теоријских конструката и категорија из области културе и безбедности у једну смислену целину, која даје потпуније објашњење како је настајао и како се градио концепт безбедносне културе.

На основу различитих дефиниција и тумачења, више теоријских приступа, прво смо закључили да култура у својој сложености и слојевитости даје различите одговоре о својој природи, концептуалној развијености, о томе чему служи и како се може разумети и применити када уплови у поље безбедности.

У двадесетом веку највише је истицан значај културе и она се заправо највише проучавала кроз већи број научних дисциплина, укључујући антропологију, социологију и психологију. Култура се реализује једино унутар друштва и део је свих друштвених структура, подсистема и односа (друштвених активности), али може да постоји и у виду посебног „концентрата“ у језику, науци, уметности, етичком учењу, филозофији и сличним дисциплинама. Непрекидно се отелотворује у друштву, али исто тако и друштво непрекидно ствара културу.

Видели смо да је култура основни атрибут друштва и готово познат концепт, али га је ипак тешко дефинисати на јасан начин. Као што је и представљено у раду, она има много аспеката и експонира се на бројне начине. Култура је у сваком појединцу и утиче на све што ради: начин на који опажа и остварује интеракцију са светом, начин на који се носи са сопственим животом, начин на који решава конфликте.

У култури су кроз знање, норме и вредности утемељене разноврсне варијанте могуће активности које доприносе повезаности културе са другим феноменима, како би заједно омогућиле већу стабилност друштвеног система, друштвене структуре и друштвених односа. На тај начин култура помаже друштву да адекватно реагује на непредвиђене промене. Уколико су веће залихе културне акумулације, утолико су и друштво (сви друштвени параметри) и, нарочито, 
друштвени односи стабилнији. Наиме, култура обезбеђује неопходну оријентацију индивидуама за живот у датој друштвеној заједници и шире у свету и за успостављање односа са другима, али и према самима себи. Све то се постиже кроз развој и унапређење свих ресурса како би се достигли хумани циљеви и хуманизму прикладни ступњеви развијености.

Развој у којем је култура доминантна основа, обезбеђује равнотежу између очувања специфичности (путем ослањања на сопствене материјалне и духовне pecypсе) и освајања ново̄г, тј. обогаћење новим специфичностима (отварањем сопствене културе према другим културама, као и контактима са спољним светом). Друштвена улога и значај културе у савременом свету имају потпуни легитимитет, јер је она повезана са свим токовима друштвеног живота, интегрисана у све друштвене појаве и процесе, па, с тим у вези, све више показује доминантна својства у односу на ранија, маргинална.

Култура је важна за човека, пре свега, јер је била од кључног значаја када је настајала људска врста. Рођење и раст културе омогућили су човеку да слободу и безбедност постиже кроз освајање и култивисање природе, али и изградњу друштва и друштвеног живота. Често се и каже да је пољопривреда најбоља култура, при којој човек може да буде безбедан. Култура се може представити као збир активности, чијим извршавањем однос појединца према значајним аспектима стварности може бити стваран или замишљен, или, као што смо и назначили, са антрополошког становишта, култура је начин живота, начин размишљања и начин богослужења.

На основу приказа различитих приступа култури утврдили смо постојање више феномена и елемената који су се узимали у обзир при разматрању концепта културе. Пре свега, у појмовном одређењу смо уочили њен развојни пут од значења неговати и обрађивати, затим култивисати, преко обогаћивања људског духа, образовања, усавршавања духа и понашања кроз процес оплемењивања, до добијања специфично рационалистичке материјалне форме, која је поистовећује са појмом цивилизације. На неки начин, свако од ових значења преживело је и у употреби је у различитим аспектима тумачења, анализе и употребе културе и у савременим условима. 
Представљањем више теоријских приступа настојали смо да издвојимо елементе које су бројни теоретичари, својим двојаким деловањем - дубоким теоријским промишљањима или емпиријским истраживањима која су спроводили на терену - уочили и увели у теоријску расправу. На основу њих евидентирали смо корисне податке и чињенице које култури дају потребна својства и одлике, захваљујући којима проналази пут до безбедности и додаје јој преко потребну социо-културну и историјску димензију.

Утврдили смо да је, поред тога што је услов и средство људске егзистенције, култура важна и као чинилац култивисања и моделовања људског понашања, чиме остварује свој утицај на развој друштвених односа, али и укупан друштвени развој. Својим инструменталним карактером омогућава човеку да се избори са проблемима и подмири своје егзистенцијалне потребе. Но, ипак, посебан акцент смо ставили на значај научног истраживања хуманитета и чињенице о томе како треба разумети људску природу. Кроз један обновљен приступ људском знању (истовремено и људско знање и знање о човеку) утврдили смо важност разумевања човека у историјско-културном контексту и изучавања људске стварности са аспекта сазнања, вредновања и деловања.

Култура и стабилан систем вредности условили су стварање идентитета, као и свест о припадности групи, која историјски настаје и развија се кроз однос са другим групама, а који је најчешће заснован на разликама. Као битни фактори идентитета и разлике јављају се културни обрасци, који представљају смисаони оквир оријентације и интеграције једне заједнице. Они су испуњени вредносним системима помоћу којих појединци и групе разумеју себе, свет у којем живе и уједно су модели за акцију на основу изабраних циљева и промовисања пожељног начина живота.

Управо кроз упознавање вредности добијамо информације о томе према чему су дате културе усмерене и ради чега су организоване. Развој вредности усмерава културу ка традицији, али и сталној промени и напретку. Уколико је више оријентисана ка традиционализму, мање је спремна за изазове савременог развоја, али сваки развој и промена могу укључити део традиционалних 
вредности који представља одговарајућу меру да се постигне баланс међу друштвено пожељним активностима и понашањима.

Иако има много теоретичара који сматрају да културне разлике углавном доносе нестабилност, несклад, напетост, као и крајњи продукт - насиље - увек се могу евидентирати и примери где су оне фактор стабилности, значајан потенцијал за стваралаштво и друштвене интеграције. У теоријском, а потом и политичком и свакодневном животу већ су се укоренили бројни концепти са могућим решењима да се превазиђе могућност сукобљавања и нетрепељивости међу културно различитим групама. Оно што није успела асимилација покушао је да реши концепт мултикултурализма, а тамо где је он показао слабе тачке, наступа концепт интеркултурног дијалога.

Да бисмо разумели културу, морамо знати од чега је саткана и шта јој то даје јаснији садржај/суштину и израз. Посредством вредности, симбола, језика, ритуала и обичаја појединци и групе се идентификују са одређеном културом и остварују комуникацију кроз сложене односе и процесе социјализације, током којих се уобличавају истим тим елементима. Суштину културног идентитета чине симболи, засновани на заједничким веровањима, интересима и активностима.

Често се и разумевање културе заснива на чињеници да је то један акумулирани тоталитет симболичких система (као што су религија, идеологија, здрав разум, економија или спорт), на основу којих људи схватају сами себе и свет у којем живе, а на основу којих се представљају себи самима и другима. Припадници одређене културе користе симболе своје културе као језик кроз који читају и тумаче, односно изражавају и деле значења са другима. Пошто је главни циљ и услов људског постојања дати значење животу, то је и читање културе перманентан процес. Језик, као најзначајнији облик симболичке активности, мењао је своју форму, улогу и значај кроз историју, али би његови потенцијали требало да се користе превасходно за добро и за развој, а не за зло и позив на дестабилизацију и разарање, као што то чини ,језик рата“. Национални симболи имају своју историју, која се одвијала упоредо са развојем и конституисањем националног идентитета. 
Анализом елемената културе дошли смо и до њене форме, концептуализоване на националном нивоу и представљене као национална култура. Прихватајући чињеницу да она обухвата вредности, веровања, претпоставке, очекивања, запажања и понашања, које деле припадници одређене националне заједнице, онда се она не може нивелисати на општу културу, јер поседује одређене специфичности у односу на њу.

У сваком случају, национална култура је утемељена у одређеним цивилизацијским обрасцима, трајнијег је карактера на основу специфичних културних образаца, особеног искуства и начина живота народа/нације на одређеном простору. Оквир у којем се најчешће разматрају домети и могућности националне културе условљен је традицијом, променом и идентитетом. Традиција, као скуп вредности, идеја, норми, обичаја који су садржани у „историјском памћењу“, културном и националном идентитету, мора да буде присутна у развоју и напретку културе и неотуђиви део континуитета националне културе. Традиција није непроменљива константа, она мора прихватити нове вредности афирмисане као стваралаштво које сасвим уверљиво замењује наслеђено̄, те се самим тим успешније носи са изазовима модернизације. Превасходно хуманистички смисао стваралаштва, оног највреднијег и најпостојанијег, омогућава успостављање континуитета, који је једна од најбитнијих претпоставки за коегзистенцију целокупног стваралаштва, и оног из прошлости и оног из савремености.

Национални идентитет има своју историјску „причу“, саткан је од мноштва других идентитета, често је противречан у односу на то како себе види, а како га виде други, и у том смислу обухвата процес укључивања и искључивања. У сваком случају, извориште је националних интереса националне групе која посредством националне културе развија и често учествује у реконституисању тог националног идентитета.

Коначно, још једном смо потврдили како национална култура постаје национални и јавни интерес, било на начин да их конституише, било да их регулише. Национална култура представљена као национални интерес негује активан однос према националним вредностима, постављајући темеље за 
задовољење основних потреба свих грађана и државе у целини. Такође, кроз различите активности учешћа у културном стваралаштву, али и припадност различитим друштвеним мрежама, она развија друштвени капитал и пружа погодности за повећање нивоа добробити свих чланова заједнице. Све тешње прожимање главних питања друштвеног развоја културом појачава њену инструменталну улогу у обликовању и усмеравању тог развоја, али исто тако и помаже опажању потенцијалних и стварних угрожавања (извора̂, облика̂ и носилаца).

С друге стране, пратили смо развој мисли о безбедности и начин на који је концепт културе ушао у поље безбедности, разматрајући у том оквиру и питање идентитета (са националним обележјима) и питање националне безбедности. Попут културе, и развој појма безбедности имао је специфичне историјске конотације у разноликом поимању његове суштине. Током времена прихваћена су његова објективна и субјективна разумевања, осликана у знањима која се поседују о опасностима и могућности или способности да им се одупре и да се „влада“ ситуацијом, чувајући вредности које су изабране као пожељне и достојне очувања и заштите.

Представљањем социолошког, правног и политиколошког приступа безбедности видели смо како су различите дисциплине разумеле, тумачиле и употребљавале појам безбедности. Социолошки приступ је значајан за разумевање разноликих погледа и искустава поводом безбедности, које имају одређене друштвене групе (издвојене по полној, етничкој/националној, професионалној основи и сличним својствима). Као најважнији резултат овог приступа издвојили бисмо чињеницу да се друштвени живот у свакој заједници заснива не само на избегавању опасности и ризика, већ и на спремности да се делује у поверењу и очекивању да ће и други узвратити поверењем, као важном основом безбедне друштвене интеракције унутар група и између различитих друштвених група.

Правни и политиколошки приступ углавном се позивају на позитивноправно дефинисање безбедности, њена спољна обележја, нормативно устројство, организациону структуру и начин на који држава уређује и контролише 
друштвене односе унутар својих граница и на спољном плану, стварајући услове да се безбедност подигне на задовољавајући и пожељан ниво.

Пошто дебата између реалиста̂ и либерала̂ у другој половини XX века није задовољила у одговорима које је пружила на питање како функционише свет, јер су предност у њиховим анализама имали материјални фактори, јавила се потреба да се у оквир анализе уведу и идејни или идеацијски фактори, чија основа лежи управо у култури.

Студије националног карактера из 40-их и 50-их година XX века, које су дефинисале напоре да се укаже на везу између културе и понашања државе, засноване су углавном на антрополошком моделу. Данас је култура поново у фокусу научног интересовања у развоју студија националне безбедносне политике, где културни ефекти значајно доприносе великим стратегијама и понашању државе, али су исто тако битни и за унутардржавно устројство и безбедносне политике које се воде у оквиру различитих референтних оквира. Као што смо назначили у раду, анализирани су не само аспекти који се односе на домен државе, већ и унутрашња димензија државног и друштвеног простора, као и димензија појединца.

Да бисмо променили визуру кроз коју посматрамо и анализирамо безбедност, уважавајући културу као једну нову компоненту и фактор који даје потпунију и јаснију слику како тај појам „ради“, фокусирали смо се на истраживање у том домену. Проширењем агенде безбедносних студија шири се визија безбедности и потврђује и даље њена привлачност и моћ. Некада оспоравана рационалистичким и материјалистичким ставовима, кроз социјалну конструкцију деловања, поред питања културе, у поље анализе се уводе и питања идентитета и интереса, па самим тим дају један потпуно другачији и сложенији оквир у којем се креће безбедност.

Промене у пољу безбедности подразумевају, поред схватања безбедности као одсуства егзистенцијалних претњи држави, разматрање и нових предмета безбедности, а то су нпр. друштвене, етничке, верске или друге културне мањине (друштвена безбедност), појединци са својим потребама (људска безбедност) или читаво човечанство (глобална, или светска безбедност). Дакле, 
нови носиоци безбедносних потреба налазе се у истој равни и располажу једнаким правима као и држава.

Такође, поред физичко-политичке димензије безбедности територијалног ентитета у времену сложених међузависности, појављују се и нови аспекти у вези са безбедношћу људских живота, као што су: доступност економских pecypca, изграђеност и стабилност институција и могућности да обезбеди адекватан ниво заштите (економска сигурност), интегритет система да понуди информације о процесу од којих зависи модерно друштво (безбедност информација) и природна средина, као основа за сав живот, али и добављач ресурса на којима се развијају друштва и државе (еколошка безбедност).

Безбедносни концепт се развија тако да се све јасније уочава његова веома комплексна структура. У оквиру те структуре постоји велики број комбинација актера и врсте интеракција или ситуација (владе, оружане снаге, националне економије, економски режими, социјалне или религиозне групе, појединци), који се морају узети у обзир при разматрању бројних питања и проблема у области безбедности.

Када се наводе претње, од њих не можемо одвојити вредности које се налазе у опасности или, тачније, оно што људи вреднују и о чему брину. Тврдња да је опстанак једина важна вредност поједностављује то питање. Опстанак, за људску заједницу, не одговара увек физичком опстанку појединца. Заједница је дефинисана на вредностима или заједничком поверењу, које обликује заједничко постојање и које се може разликовати од једне заједнице до друге. Када лидери циљају на заштиту „начина живота“, то није само страх од смрти, већ и губитак аутономије (суверености) у одређивању вредности које темеље тај живот.

Уплив културе у поље безбедности одиграо се преко идентитета, а везе између ових категорија остварују се на више различитих начина. Ако се у тим разматрањима прихвати конструктивистички приступ, култура постаје део националног идентитета, она ствара вредности које опредељују конституисање интереса, а као један од најважнијих - и интерес безбедности. Постојећи систем вредности је најпродуктивнији ако подстиче стварање добробити и 
развоја, те самим тим даје добру основу за оквир националне културе која ће обликовати реакције и понашање државе у односу на безбедносну претњу, током процеса остваривања националне безбедности. Много већа добробит и могућност за развој биће постигнуте ако се развијају капацитети за сарадњу, и то најпре засновани на заједничком систему вредности. Заједничке вредности стварају повољну основу за пружање шансе дијалогу, када се траже примерена средства да се реши неспоразум или неки озбиљнији облик нетрпељивости, који лако може прерасти у сукоб.

Култура, као што смо видели, има специфичну природу, која се у стварности може испољити на два различита начина - један који води у деструкцију и други који стреми стваралаштву. Њени капацитети се морају усмеравати тако да она изврши најприкладнији избор између алтернативних решења, јер само тако друштво може бити безбедно и ићи напред.

Такође, за безбедност су од кључне важности могућности културе да буде исходиште или упориште безбедности, испољена кроз материјалне и духовне форме које се најчешће изражавају једна помоћу друге и проналазе смисао у синтези културних елемената у сложеније и богатије комплексе. Материјална форма даје темеље „тврдој“ моћи, коју (поред „меке“) култура такође може да произведе, а духовна форма изражава, између осталог, специфичан филозофски, религиозни, морални и политички поглед на свет, утемељује њене капацитете „меке“ моћи.

Културни обрасци у сфери безбедности представљају оквир размишљања и понашања којим се руководе чланови једне заједнице када је у питању виђење опасности, тога одакле она долази, како се испољава и постаје озбиљна претња, на који се начин и којим средствима супротставити, како се изграђују структурни елементи и институције у том домену.

Култура има више функција, захваљујући којима добија улогу националног безбедносног интереса, а у раду смо говорили о настанку тих функција, развоју и историјским перспективама, са посебним приказом колико су значајне за област безбедности. Пошли смо од функције опстанка, која је првобитно омогућила човеку да преживи и која данас поново мора мотивисати човека да 
се бори не само за опстанак своје врсте, већ и читаве планете Земље. Функција комуникације је значајна, јер омогућава контакт, размену информација, успостављање сарадње, узајамно поверење и, уз све то, даје смисао и значење сваком односу који се успоставља у неком процесу размене идеја и мисли.

Захваљујући култури и њеној нормативној функцији установљавају се и развијају норме и правила помоћу којих се утиче на правце корисног и сврсисходног понашања, а спречава штетно и друштвено неприхватљиво деловање. Култура ствара различита заштитна средства, а безбедноснозаштитна функција најчешће се заснива на активностима предвиђања и планирања, како би се правовремено одредило која је средства и у којем обиму неопходно употребити. Ова функција проистиче из опредељења друштва или заједнице да разликује добро од зла, да изабере шта је добро, а шта не за друштво у целини, те да се изабране вредности сачувају примењујући решења која обезбеђују опстанак, пружају заштиту, одржавају ред и мир, али и дају смисао свему што друштво и појединац производе.

Коначно, кумулативна функција је можда и најважнија, јер је омогућила акумулирање и ускладиштење резултата људског деловања и у материјалној и у духовној сфери током читаве историје одређене групе, народа или нације или пак читаве људске заједнице. Управо је потенцијал који ова функција носи изузетно значајан за развој концепта безбедносне културе, јер снага и величина материјалне културе, историјска сећања, акумулирана знања и духовно богатство једног народа, попут акумулиране енергије, готово да немају ограничења у одржавању духовног здравља и специфичног начина живота који води напретку и развоју.

Акумулираним знањима, вредностима и веровањима, потенцијалом који развија креативност и иновативност, национална култура омогућава да се лакше дође до одговора како да се заштите и сачувају виталне вредности, тј. вредности које се најбоље штите језгром савременог концепта безбедности националном безбедношћу. За разлику од традиционалних виђења безбедности, која нису укључивала културну компоненту у својим анализама, савремена тумачења и погледи на безбедност и националну безбедност посебно 
уважавају културу и не устручавају се да је уведу у оквир анализе. Као што се показало исправним, идејна основа, антрополошка сазнања, појединачна и колективна психологија, представе и значења јесу друштвени чиниоци који су из темеља преобликовали материјалну структуру и шире и продубљеније разматрали категорије попут идентитета и његове релације према култури и безбедности.

Као што је на почетку постављено, култура, а потом и њена ентитетска форма национална култура - прошла је дуг пут од тога да је играла најважнију улогу у преживљавању првобитног човека, до тога да је постала значајан ресурс и извор очувања и развоја живота људи, очување и развој друштва, заједнице и појединца у савременим условима.

Генерације научника су тражиле начин да подстакну веће разумевање за односе културе и безбедности, који су се углавном манифестовали кроз понашање државе. Стратешке културалне студије обезбедиле су богате описе специфичних култура и идентитета, а истраживачи су признали важне везе између различитих актера који одређују стратешку политику. Истраживања су такође потпомогнута богатим материјалом који је добијен из других дисциплина, као што су: антропологија, историја, социологија и психологија. Поред тога, научници су, под утицајем конструктивизма, почели са истраживањем начина на који је обликована првобитно стратешка, а сада можемо говорити и безбедносна култура, која је временом еволуирала. Као резултат тога, мимо очекивања многих, а уз признање и скептика̂, савремени рад на култури понудио је приметно више од пуког објашњења.

У овом раду је безбедносна култура представљена као концепт који се налази пред изазовом да превазиђе противречности какве прате савремени развој међународних односа, али и развој друштва и државе унутар својих граница, у околностима нових безбедносних изазова, ризика и претњи. Трудили смо се да објаснимо како су култура и безбедност, као посебни феномени, довољно распрострањени и довољно важни за развој сваког појединца, групе, државе, односно друштва у целини. Такође, они изнова заслужују пажњу истраживача̂ 
и теоретичара̂, а нарочито када се поставе у однос који производи нешто ново, што превазилази њихове појединачне вредности и значај.

Наиме, овај рад се фокусирао на продубљеније разумевање синтезе концепта културе и концепта безбедности, њихових трансферних могућности у теорији и пракси, као и развојних капацитета, како би се поставили стабилни темељи за концепт безбедносне културе. На моменте се може чинити да смо се окренули превише уназад, како бисмо се домогли општијег погледа у са̂м проблем, дакле, идентификовање неких кључних појмова и принципа за које сматрамо да треба да се користе при постављању основе за овај теоријски концепт. ${ }^{328}$

У сваком случају, у теорији је одавно познато да се концепти могу представити као једноставни или сложени, што можемо да утврдимо анализирајући их, дакле, ако се утврде делови који их сачињавају, али и одреди њихов однос са другим концептима. При том, једно је питање анализа самог концепта и елемената који га чине (што понекад могу бити и концепти сами по себи, као што су засебно посматрани култура и безбедност), а друго је питање улоге, функције концепта, дакле како или чему може послужити. Потражња и потреба за концептом безбедносне културе потиче из тотализације безбедности и

328 Зашто је важно бавити се културом и безбедношћу на једном дубљем нивоу - да се не би ширила духовна пропаст (западне) културе, о којој је Т. С. Елиот још 1922. године писао у својој књизи Пуста земља. Наиме, као што је познато, у миту о светом Гралу пуста земља је место где људи живе испразним животом, слепо сле́дећи правила свог друштва без уверења која проистичу из дубљег поимања ствари. И Елиот се пита: како стваралаштво може да пусти корен у „каменом смећу“ модерног доба, у којем су људи изгубили додир са митском потком своје културе? Разумети унутрашњи склад своје баштине и пронаћи свети Грал као симбол „знања, мудрости и светости“, који ће животу дати смисао или послужити као иницијација за болан ритуални прелазак из једне фазе живота у другу, из једног стања ума у друго стање, што је веома тежак задатак и улога. Разумети безбедност и бавити се безбедношћу на један нов начин, обогаћен и обликован културом, може бити пут који треба следити. Ништа не почиње од нас, од јуче или од данас, а културна баштина, културно наслеђе - дакле, акумулирано знање и енергија - „крију“ многе одговоре које, правовременим откривањем и разумевањем, можемо ставити у службу данашњих човекових потреба и интереса. Ти интереси и потребе се тренутно највише изражавају у сфери безбедности, а очекује се да ће тако бити и убудуће. 
енормног повећања комплексности безбедносних проблема. Тотализација значи да безбедносна питања, проблеми и аспекти постају све очигледнији у свим аспектима живота.

Концепт безбедносне културе има аналитичке и нормативне сврхе. Он истражује који фактори улазе у оквир анализе, доприносећи већој безбедности, и који друштвено-политички и економски односи највероватније генеришу максималну безбедност за појединце, групе, нације-државе и свет као целину. При том је потребно развити способност да се разумеју и поштују улога и утицај културе на политику, стратегију и безбедност, што је и кључна вештина безбедносног размишљања. Културно знање подразумева способност да се размотре историја, вредности, идеологија, политика, религија, културне и друге димензије, али и процени њихов потенцијални утицај на безбедносну политику. Нагласили бисмо да не само знање о безбедности и безбедносним феноменима (како је у неким дефиницијама наведено), већ и културно знање, макар и ако послужи само као контекст у којем се нека безбедносна појава одвија, значајни су за развој нових перспектива безбедносне културе.

Изражено је све снажније занимање од стране националних безбедносних актера и других учесника друштвеног живота за културу као важан фактор у системским опредељењима и решењима развоја институција, које ће, између осталог, бити предуслов за успешно надгледање безбедносних ризика, решавање конфликта или постати незаобилазан део безбедносне инфраструктуре.

Представљајући безбедносну културу као фактор развоја националне безбедности, размотрили смо два битна процеса; први, као трансфер националне културе у безбедносну културу, и други, као трансфер националне безбедности у безбедносну културу. Безбедносну културу смо сагледали и у светлу регионалних, интернационалних и глобалних процеса у свету, као и кроз могућност да се институционално развије у односу на друштвене интеграције, односе према држави и у оквиру међународних односа. Да би концепт могао да се развија и примењује, такође, постоји више решења и 
препоручених модела, али смо у раду указали на најбитније: образовање, обавезивање, контрола и примена стандарда̂.

Методологије и модели истраживања безбедносне културе могу се представити на основу више приступа, али издвојили смо неколико и дали само опште напомене за оквир истраживања, дакле, приказали смо: приступ организационе културе, приступ кроз супкултуре, приступ са аспекта социјалног и културног капитала те хуманолошки приступ. Сви приступи, а посебно хуманолошки, захтевају веће учешће човека, дакле не само као објекта сазнања, већ и активног субјекта који ствара, обликује и разуме стварност и сазнања о стварности.

У сваком случају, морамо указати на чињеницу да постоји отворен простор за усавршавање програма, методологија и модела истраживања. Међу областима на које треба обратити пажњу налазе се: развој заједничке дефиниције безбедносне културе за развој прогресивних теоријских модела; описивање начина на који се безбедносна култура уобличава, одржава и преноси новим генерацијама; питање универзалности безбедносне културе; као и усавршавање повезаности између различитих извора безбедносне политике.

Можемо, на крају, оценити да безбедносна култура одређује кораке и приступ безбедности и небезбедности, али и дефинише вредности као оријентире људскости који ће бити задовољени на путу остваривања националне безбедности, рефлектоване и на нивоу нације, друштва и на нивоу појединца. Безбедносна култура се може представити као једна од најбитнијих категорија савременог концепта безбедности, заснована на материјализацији замисли безбедности, а, с обзиром на то да њена пуна афирмација тек предстоји, неопходно је развијати и подржавати истраживања у тој области. Попут других, и овај концепт се може видети као мост између ума и света, битан у толикој мери да они од нас захтевају да променимо оно што сматрамо умом и шта сматрамо светом, а својом отвореношћу ће помоћи да се људи уче новим компетенцијама.

Овај рад је покренуо питања и покушао да оцрта неке од димензија које се морају узети у обзир ако се опредељујемо за озбиљније бављење безбедносном 
проблематиком. То значи да морамо имати системски приступ - правилно разликовати ствари које су важне за постизање циља (веће безбедности, развој и добробит заједнице и друштва и слично) од неважних. Системски приступ захтева темељито филозофско и логичко знање и способност примене тог знања. То запажање нас упућује и на чињеницу да је очигледно да безбедносна култура потиче из опште културе, али и да своја суштинска својства црпе из националне културе. Са методолошке стране је потребно добро размислити о томе да ли је моћ разума и науке довољна да се разуме и контролише неизвесност природних и друштвених појава или пак треба и у којој мери укључити вредносне идеје и норме, према којима се човек управља, без обзира на то што им многи стручњаци не поклањају поверење.

Други важан аспект је „свест о безбедности“, што значи да свако мора настојати да разуме и јасно види ризике својствене специфичној активности и његовом извођењу у односу на вредности које су од значаја за појединца, друштво или заједницу. Неопходно је показати спремност да се сагледа потенцијална штета настала реализацијом ових ризика и утицаја на противмере које предузимају са̂м појединац или други субјекти, како би се спречило оштећење или погоршање услова у којима се примењују. Укупна свест о безбедности углавном подразумева свесно управљање ризиком. Прелаз са свесног избегавања ризика на управљање ризицима важна је одлика безбедносне културе.

Трећу ствар на коју је потребно ставити акцент представља улога безбедносне културе у развијању способности сарадње - тачније, потреба да се учини општи и природан напор у погледу сарадње у домену безбедности. Нове форме сарадње треба да радикално прекину са старим праксама и наметну обавезу свим актерима из државне и друштвене сфере, јавним агенцијама и пословним организацијама као и појединцима, да сарађују једни са другима у циљу побољшања безбедносних правила и прописа, подстакну интерактивно деловање уместо прописивања извршења правилима и захтевима усвојеним од стране државе. Способности да се постигне консензус и да се оствари координација битни су услови сарадње. Консензус, слично као и сарадња, није само питање етичке намере - он такође захтева професионалан приступ и 
стручно знање и вештине. Обе морају да се науче и у том смислу је изузетно важна улога националног образовног система, друштвене елите и стратешких опредељења у избору начина и средстава за вођење националне безбедносне политике. 


\section{Литература}

1. Adler, Emmanuel and Michael Barnett (eds.), Security Communities, Cambridge, Cambridge University Press, 1998.

2. Adler, Emmanuel, and Beverly Crawford, Constructing a Mediterranean Region: A Cultural Approach, To be presented at the Conference on „The Convergence of Civilizations?“, Portugal, 2002.

3. Alexander, Jeffrey C., Culture and society, Cambridge, Cambridge University Press, 1994.

4. Армстронг, Карен, Кратка историја мита, Геопоетика, Београд, 2005.

5. Арон, Рејмон, Мир и рат између народа, Голден маркетинг, Загреб, 2001.

6. Асман, Алаида, Рад на националном памћењу, Библиотека XX век, Београд, 2002.

7. Асурменди, Мигел, Идентитет и насиље, Библиотека XX век, Београд, 2002.

8. Attina, Fulvio, The Building of Regional Security Partnership and the Security Culture Divide in the Mediterranean Region, Institute of European Studies, University of California, Berkeley, 2004.

9. Acharya, Amitav, A Regional Security in Southeast Asia, The Journal of Strategic Studies, 18/1995.

10. Acharya, Amitav, „How Ideas Spread: Whose Norms Matter? Norm Localization and Institutional Change in Asian Regionalism“, International Organization, 58(2), 2004.

11. Бајагић, Младен, Основи безбедности, Криминалистичко-полицијска академија, Београд, 2007. 
12. Банч, Шарлот, Поглед на хуману безбедност и феминистичка перспектива људских права, Људска безбедност, тематски број „Род и људска безбедност“, Београд, 2005.

13. Бауман, Зигмунт, Култура и друштво, Просвета, Београд, 1984.

14. Бауман, Зигмунт, Флуидни живот, Mediterran Publishing, Нови Сад, 2009.

15. Бен, Рејк, и Кристина Едкок, Вредности, ставови и промена понашаға, Нолит, Београд, 1978.

16. Бенедикт, Рут, Обрасии културе, Просвета, Београд, 1976.

17. Benedict, Jan \& E. M. Steenkamp, „The role of national culture in international marketing research“, International Marketing Review, vol. 18, iss. $1,2001$.

18. Берк, Питер, Основи културне историје, Клио, Београд, 2010.

19. Betts, Richard K., „Is Strategy an Illusion?“, International Security, 25/2 (Fall 2000).

20. Bigo, Didier, „International Political Sociology“, In Security Studies, An Introduction, ed. Paul D. Wiliams, Oxon/New York Routledge, 2008.

21. Божовић, Ратко Р., Живот културе, „Филип Вишњић“, Београд, 2009.

22. Burgess, Peter J., Security as Ethics, Policy Brief, No 6/2008, Oslo: PRIO, 2008.

23. Burgess, Peter J., „What is security culture?“, The New ethos of risk, International Peace Research Institute, PRIO, Oslo, s.a.

24. Burgess, Peter J., (ed.), The Routledge Handbook of New Security Studies, Routledge, 2010.

25. Богдановић, Марија, Методолошке студије, Институт за политичке студије, Београд, 1993.

26. Бодин, Миленко, „Хуманологија и хуманолошке науке“, Зборник радова, Факултет цивилне одбране Универзитета у Београду, 2002. 
27. Бодин, Миленко, Теоријски основи менаимента националне безбедности, докторска дисертација, Факултет безбедности Универзитета у Београду, Београд, 2007.

28. Бодин, Миленко, „Теоријске претпоставке разумевања и остваривања националне безбедности“, у: Ризик, моћ, заштита. Увођење у науке безбедности, Службени гласник и Факултет безбедности, Београд, 2010.

29. Бугарски, Ранко, Језик од рата до мира, Чигоја штампа, Београд, 1997.

30. Бугарски, Ранко, Језик и култура, Библиотека XX век, Београд, 2005.

31. Бугарски Ранко, Језик и идентитет, Библиотека XX век, Београд, 2010.

32. Booth, K., New Thinking about Strategy and International Security, HarperCollins Academic, London, 1991.

33. Вајт, Лесли, Наука о култури, Култура, Београд, 1970.

34. Wendt, Alexander, "Constructing international politics", International Security, vol. 20, No. 1, 1995.

35. Williams, Michael C., Culture and security, Routledge, London, 2006.

36. Williams, Raymond, Key Words: A Vocabulary of Culture and Society, Rev. edn., Oxford University Press, New York, 1985.

37. Вилијамс, Рејмонд, „Анализа културе“, у: Студије културе, Зборник, Службени гласник, Београд, 2008.

38. Wood, C., "Integrated Approach Includes Information Security", Security 37(2), 2000.

39. Галтунг, Јохан, Мирним средствима до мира. Мир и сукоб, развој и цивилизација, Службени гласник, Београд, 2009.

40. Galtung, Johann, There are Alternatives! Four Roads to Peace and Security, Nottingham: Spokesman, 1984.

41. Gellner, Ernest, Culture, Identity and Politics, Cambridge University Press, Cambridge, 1987.

42. Герц, Клифорд, Тумачење култура 1, Библиотека ХХ век, Београд, 1998. 
43. Гиденс, Ентони, Социологија, ЦИД, Подгорица, и Романов, Бања Лука, 2001.

44. Голубовић, Загорка, Антропологија, Службени гласник, Београд, 2007,

45. Горуновић, Гордана, Антропологија Клифорда Гериза - Културна теорија и интерпретативна анализа култура, Филозофски факултет Универзитета у Београду, Београд, 2010.

46. Грамши, Антонио, Хегемонија, интелектуалци и држава, Зборник, Службени гласник, Београд, 2008.

47. Gray, Collin, „What RAND Hath Wrought“, Foreign Policy, No. 4, Fall 1971.

48. Gray, Collin, The Geopolitics of Superpower, Lexington, Kentucky: University Press of Kentucky, 1988.

49. Guibernau, Montserrat, The Identity of Nations, Polity Press, Cambridge, UK, 2008.

50. Guldenmund, F. W., "The Nature of Safety Culture: A Review of Theory and Research”, Safety Science 34, 2000.

51. Desh, Michael C, „Culture Clash - Assessing the Importance of Ideas in Security Studies“, International Security, Vol. 1, 1998.

52. Дивјак, Слободан, Проблем идентитета - културно, етничко, нациионално и индивидуално, Службени гласник, Београд, 2006.

53. Dillon, M., Politics of Security - Towards a political philosophy of continental thought, Routledge, London, New York, 2003.

54. Dobbin, Frank R., Cultural Models of Organization: the social construction of rational organizing principles. In Sociology of Culture: Emerging Theoretical Perspectives, ed Crane Dian, Basil Blackwell, London, 1994.

55. Доло, Луј, Индивидуална и масовна култура, Клио, Београд, 2000.

56. Dover, John, War Without Mercy: Race \& Power in the Pacific War, New York: Pantheon Books, 1986.

57. Дулић, Драгана, Станаревић, Светлана, Николић Весна, Стағе и периепција људске безбедности - ка успостављағу индекса људске 
безбедности, Извештај за 2008. годину, Фонд за отворено друштво, Београд, 2010.

58. Ђорђевић, Обрен, Лексикон безбедности, Партизанска књига, Београд, 1986.

59. Ђурић, Михаило, Историја политичке филозофије, Албатрос плус, Београд, 2010.

60. Edwards, Geoffrey, "Is There a Security Culture in the Enlarged European Union", The International Spectator, 3/2006.

61. Елиот, Томас, Ка дефиницији културе, Просвета, Ниш, 1995.

62. Енщиклопедија политичке културе, Савремена администрација, Београд, 1993.

63. Иванчевић, Никола С., Друштвена самозаштита, Факултет народне одбране, Универзитет у Београду, Београд, б.г.

64. Ивић, Павле, „Књижевни и народни језик код Срба“, Историја српског народа, II књига: Доба борби за очување и обнову државе (1371-1537), СКЗ, Београд, 1982.

65. Илић, Милош, Социологија културе и уметности, седмо издање, Научна књига, Београд, 1983.

66. Инђић, Триво, Технологија и културни идентитет, Службени гласник, Београд, 2009.

67. Insitucije $i$ institucionalizam, priredili: Petar Bojanić i Ivan Mladenović, Službeni glasnik, Beograd, 2010.

68. Јовановић, Слободан, Културни образаи, Стубови културе, Београд, 2005.

69. Calvert, John, „The Mythic Foundations of Radical Islam“, Orbis, Foreign Policy Research Institute, Winter 2004.

70. Карић, Владимир, „Народни дух и осећање“, у: Карактерологија Срба, прир. Бојан Јовановић, Научна књига, Београд, 1992. 
71. Katzenstein, Peter J., ed., The Culture of National Security. Norms and Identity in World Politics, New York: Columbia University Press, 1996.

72. Кекић, Далибор, Култура националне безбедности у савременом концепту безбедности, Безбедност, Београд, 2/2004.

73. Kelman, H. C. (2006), „Interests, relationship, identities: Three central issues for individuals and groups in negotiating their social environment", in: S. T. Fiske, A. E. Kazdin \& D. L. Schaster (eds), Annual Review of Psychology (vol. 57, pp. 1-26), Palo Alto, CA Annual Reviews.

74. Кимлика, Вил, Мултикултурализам - мултикултурно грађанство, ЦИД, Подгорица, и Јесенски и Турк, Загреб, 2004.

75. Kymlicka, Will, Liberalism, Community and Culture, Oxford University Press, Oxford, 1989.

76. Kirchner, Emil J. \& James Sperling (eds), National Security Cultures Patterns of global governance, Routledge, London and New York, 2010.

77. Кјенјевич, Јан, Увод у историју цивилизащије Истока и Запада, Службени гласник, Београд, 2011.

78. Clements, Kevin, Toward a Sociology of Security, Working Paper 90-4, Department of Sociology University of Canterbury Christchurch 1, New Zealand, July, 1990.

79. Клосковска, Антоњина, Социологија културе, Чигоја, Београд, 2001.

80. Cohen, R., and Mihalka, M., Cooperative Security: New Horizons for International Order, „The Marshall Center Papers“, No. 3, 2001.

81. Коковић Драган, Жолт Лазар: Чиниоци неговања националног и културног идентитета у Војводини, Социолошки преглед, Vol. XXXVII, 2003, nо. 1-2, стр. 49-59.

82. Cox, S., Flin, R., „Safety culture: Philosopher’s stone or man of straw?“, Work \& Stress, 12 (3), 1998.

83. Connolly, William E., Identity/difference: democratic negotiations of political paradox, Cornell University Press, 1991. 
84. Колаковски Лешек, Мини предавања о макси стварима, Плато, Београд, 2001.

85. Кордић, Борис, Кованџић, Марија, Станаревић, Светлана, Локус сигурности, Факултет цивилне одбране Универзитета у Београду, Београд, 2006.

86. Kroeber, Alfred Louis, The Nature of Culture, University of Chicago Press, Chicago, 1952.

87. Crane, Dianne, ed., Sociology of Culture: Emerging Theoretical Perspectives, Basil Blackwell, London, 1994.

88. Khripunov, Igor, and James Holmes, Nuclear security culture: The Case of Russia, Center for International Trade and Security, University of Georgia, December 2004.

89. Lantis, Jeffrey S., Derryl Howlett, "Strategic Culture", in Strategy in the Contemporary World, Edited by John Baylis, James Wirtz, Colin S. Gray, and Eliot Cohen, Second Edition, Oxford University Press, 2007.

90. Lapid, Y., Yosef Kratochwil, eds., Return of Culture and Identity to IR Theory, Boulder, Colo.: Lynne Rienner, 1996.

91. Lévi-Strauss, Claude, The Structural Study of Myth, Suffolk: Basic Books, 1963.

92. Лексикон савремене културе. Теме и теорије, облици и институције од 1945. до данас, приредио Ралф Шнел, Библиотека Посебна издања, Плато Books, Београд, 2008.

93. Лечнер, Френк Џ., Џон Боли, Култура света, Клио, Београд, 2006.

94. Лукић, Радомир, Увод у право, Научна књига, Београд, 1978.

95. Mazarr, J. Michael: Culture and International Relations: A Review Essay, Washington Quarterly, 19:2 (Spring 1996).

96. Мајер, Томас, Идентитет Европе, ИП Албатрос плус, ЈП Службени гласник, Београд, 2009. 
97. Maxwell, D. Taylor, „The Legitimate Claims of National Security“, Foreign Affairs, 1974, Vol. 52,

98. Малиновски, Бронислав, Научна теорија културе, „Вук Караџић“, Београд, 1970,

99. Маркузе, Херберт, Култура и друштво, БИГЗ, Београд, 1977.

100. Mc Sweeney, Bill, Security, Identity and Interests: A Sociology of International Relations, Cambridge University Press, 1999.

101. Метју, Арнолд (прир.), Култура и анархија, Зборник, Службени гласник, Београд, 2008.

102. Милс, Рајт, Елита власти, Култура, Београд, 1964.

103. Митровић, Љубиша Р., Омладина Балкана и култура мира у контексту савремених структурних промена, у: Зборник радова Омладина Балкана између насиља и културе мира, Центар за социолошка истраживања Филозофског факултета у Нишу, Ниш, 2007.

104. Мијалковић, Саша, Нащионална безбедност, Криминалистичкополицијска академија, Београд, 2009.

105. Микецин, Вјекослав, Култура и друштво, Културно-просвјетни сабор Хрватске, Загреб, 1989.

106. Милашиновић, Радомир: Безбедносна култура као фактор превенције друштвених конфликата, Зборник радова, Факултет цивилне одбране Универзитета у Београду, Београд, 2005.

107. Müller, H., Security cooperation, in: Carlsnaes W., Risse T., Simmons B. A., eds., Handbook of International Relations, Sage Publications, London, 2002.

108. Милић, Војин, Социолошки метод, Нолит, Београд, 1978.

109. Милошевић, Новак, Милојевић, Саша: Основи методологије безбедносних наука, Полицијска академија, Београд, 2001.

110. Мојић Душан : Организација и национална култура, Социологија, Vol. XLIX (2007), $\mathrm{N}^{\mathrm{o}} 4$. 
111. Moore, Rebecca R., NATO's New Mission, Westport, CT Praeger; Howorth, Jolyon, 2007.

112. Најман, Велизар Н., Основи друштвене самозаштите, Привредна штампа, Београд, 1979.

113. Niskanen, T. (1994), „Safety climate in the road administration“, Safety Science, 17, pp. 237-255.

114. Northrup, Terrie, Personal Security, Political Security: Relationship Between Conceptions of Gender, War and Peace, paper submitted for publication, in L. Kreisberg (ed.), Research in Social Movements, Conflict and Change, Syracuse University, Vol. 12, 1990.

115. Павловић, Мирјана, Срби у Чикагу - проблеми етничког идентитета, Етнографски институт САНУ, Издавачка задруга ИДЕА, Београд, 1990.

116. Patrick, Allan D., Understanding Military Culture: A Canadian Perspective, McGill-Queen's University Press, Montreal, Canada, 2004.

117. Peace, security and conflict prevention, SIPRI UNESCO Handbook, Oxford University Press, 1998, 230 pp.

118. Петровић, Сретен, Митологија, култура, ичивилизација, Чигоја штампа и Салус, Београд, 1995.

119. Раденовић, Сандра, „Национални идентитет, етницитет, (критичка) култура сећања“, Филозофија и друштво, Београд, 3/2006.

120. Rosenau, James N., New Dimensions of Security: The Interaction of Globalization and Localizing Dinamics, Security Dialogue 25, no. 3, September, 1994.

121. Саид, Едвард, Оријентализам, Библиотека XX век, Београд, 2008.

122. Серпел, Роберт, Утииај културе на понашање, Нолит, Београд, 1978.

123. Симић, Драган, Поредак света, Завод за уџбенике и наставна средства, Београд, 1999.

124. Симић, Драган Р., Наука о безбедности, Службени лист СРЈ и ППН, Београд, 2002. 
125. Смит, Антони Д., Наџионални идентитет, Библиотека XX век, Београд, $1998,{ }^{2} 2010$.

126. Соколов, Е. В., Култура и личност, Просвета, Београд, 1976.

127. Стајић, Љубомир: Основи безбедности, Факултет цивилне одбране и Драганић, Београд, 2006.

128. Стајић, Љубомир, „Неке недоумице око схватања безбедности у XXI веку“, у: Ризик, моћ, заштита - Увођење у науке безбедности, приредио Владимир Н. Цветковић, Службени гласник и Факултет безбедности, Београд, 2010.

129. Стајић, Љубомир, Основи безбедности, Правни факултет Универзитета у Новом Саду, 2011.

130. Стајић, Љубомир, Контрола полищије и служби безбедности, Правни факултет Универзитета у Новом Саду, 2012.

131. Стајић, Љубомир, Мијалковић, Саша, Станаревић, Светлана, Безбедносна култура, Драганић, Београд, 2005.

132. Stanarević, Svetlana, Jasmina Gačić, Vladimir Jakovljević, „Integrating the concept of safety and security culture in the corporate security", Corporate security in dynamic global environment challenges and risks, ed. Denis Čaleta, Institute for Corporative Security Studies - ICS, Ljubljana, 2012.

133. Стефановић, Мирјана Д., Кратки увод у историју српске културе, Службени гласник, Београд, 2008.

134. Стојковић, Бранимир, Европски културни идентитет, Просвета, Ниш, 1993.

135. Стојковић, Бранимир, Културна политика европске интегращије, Институт за европске студије, Београд, 1995.

136. Стојковић Бранимир, Идентитет и комуникащија, Чигоја штампа, Београд, 2002. 
137. Strategic Culture in Strategy in the Contemporary World, Edited by John Baylis, James Wirtz, Colin S. Gray, and Eliot Cohen, Second Edition, Oxford University Press, 2007.

138. Shalom H. Schwartz, ,Are there universal aspects in the content and structure of values?“, Journal of Social Issues, 1994.

139. Schein, Edgar H., The Corporate Culture Survival Guide: Sense and Nonsense about Cultural Change, San Francisco: Jossey-Bass Publishers, 1999.

140. Тамир, Јоел, Либерални нащионализам, „Филип Вишњић“, Београд, 2002.

141. Таталовић, Синиша, Нащионална и међународна сигурност, Политичка култура, Загреб, 2006.

142. Theo, Farrel, Terry Terrif, The Sources of Military Change. Culture, Politics, Technology, Lynne Rienner Publishers, Colorado and London, 2002.

143. Terriff, T., Security Studies Today, Cambridge: Polity, 1999.

144. Тодорова, Марија, Имагинарни Балкан, Библиотека XX век, Београд, 2006.

145. Тоје, Асле, „Стратешка култура као амерички алат, историја, могућности, геополитика и вредности: пример ЕУ“, Безбедност западног Балкана, Стратешка култура и реформа сектора безбедности, бр. 14, 2009.

146. Towards a Culture of Security and Accountability, The Report of the Independent Panel on Safety and Security of UN Personnel and Premises Worldwide, 2008.

147. Transformation in the meaning of „security“: practical steps toward a new security culture, The Venice Papers, 1, 1996. CAB-96 WS/1, UNESCO, 125 pp.

148. Trompenaars, F., „Resolving International Conflict Culture and Business Strategy“, Business Strategy Review), Volume 7, Issue 3, 1996. 
149. Tucker R., „Political Culture and Communist Society“, Political Science Quarterly, vol. 88, No. 2, 1973,

150. Twomey, Christopher P., The Military Lens: Doctrinal Difference and Deterrence Failure in Sino-American Relations (Cornell Studies in Security Affairs), Cornell University Press, Ithaca and London, 2010.

151. UNESCO and a culture of peace. Promoting a global movement. 1996. CAB95/WS/1.UNESCO, 206 pp.

152. United Nations Development Programme, Latvia Human Development Report 2002/2003: Human Security, Riga, Latvia, 2003.

153. Фабијети, У., Малигети, Р., Матера, Винћенцо: Увод у антропологију увод од локалног до глобалног, Клио, Београд, 2002.

154. Фајгељ, Станислав, Методе истраживања понашања, Центар за примењену психологију, Београд, 2004.

155. Fierke, K. M., Critical Approaches to International Security, Polity Press, Cambridge, 2007.

156. Фолкер, Хајнц, Увод у Макса Вебера, Библиотека ХХ век, Београд, 2011.

157. Freeman, E., „E-Merging Risks: Operational Issues and Solutions in a Cyberage“, Risk Management 47(7), 2000.

158. Frosh, Stephen, Identity Crisis: Modernity, Psychoanalysis, and the Self, Routledge, London, 1991.

159. Фукујама, Френсис, Судар култура, Завод за уџбенике и наставна средства, Београд, 1997.

160. Фукујама, Френсис, Крај историје и последюи човек, Романов, Бања Лука, 2002.

161. Хантингтон, Семјуел, Сукоб циивилизација - преобликовање светског поретка, Романов, Бања Лука, 1998.

162. Хантингтон, Семјуел, и Лоренс Харисон, Култура је важна, Плато, Београд, 2004. 
163. Х Хач, Елвин, Антрополошке теорије, 1-2, БИГЗ, Београд, 1979.

164. Хебдиџ, Дик, „Поткултуре - значење стила“, у: Cmудије културе, Зборник, Службени гласник, Београд, 2008.

165. Hinde, S., „Recent Security Surveys“, Computer and Security 17 (3), 1998.

166. Х Хобс, Томас, Левијатан, Култура, Београд, 1961.

167. Хобсбом Ерик, Теренс Рејнџер (ур.), Измииљање традииије, Библиотека XX век, Београд, 2002.

168. Hotstede, Geert, „National Cultures in Four Dimensions“, International Studies of management and Organization, 1983.

169. Howlett, Darryl, „Strategic Culture: Reviewing Recent Literature“, Strategic Insights, Volume IV, 10, October 2005.

170. Hudson, Valerie M., Culture \& Foreign Policy, Lynne Rienner, Boulder, CO, 1997.

171. Zimmerman, William, Jacobson, Harold K., eds., Behavior, Culture, and Conflict in World Politics, Ann Arbor: University of Michigan Press, 1993.

172. Jepperson, R. L., Wendt, A., Katzenstein, P. J., „Norms, Identity and Culture in National Security“, y: Katzenstein, P. J. (ур.), The Culture of National Security: Norms and Identity in World Politics, Columbia University Press, New York, 1996.

173. Jones, Richard Wyn: Security, Strategy, and Critical Theory, Boulder, Co: Lynne Rienner, 1999.

174. Johnston, A. I., „Thinking about Strategic Culture“, International security, Vol. 19, No. 4, Spring 1995.

175. Шмит, Карл, „Појам политичкога“, у: Норма и одлука: Карл Шмит и његови критичари, прир. Слободан Самарџић, „Филип Вишњић“, Београд, 2001.

176. Шкорић, Марко, Валентина Соколовска и Жолт Лазар: Традиција, језик, идентитет, Филозофски факултет, Одсек за социологију, Универзитет у Новом Саду, Нови Сад, 2008. 
177. Шушњић, Ђуро, Знати и веровати, Чигоја штампа, Београд, 1995.

178. Walt, Stephen M. The Renaissance of Security Studies, International Studies Quarterly, Vol. 35, No. 2, 1991.

\section{Извори с интернета:}

1. http://europa.eu.int/institutions/cfsp/index_en.htm

2. http://www.ccc.nps.navy.mil/si

3. http://www.sonshi.com

4. www.csis.org

5. www.globalsecurity.org

6. www.unesco.org

7. www.unesco.org/cpp/uk/projects/pubs.htm

8. www.iep.utm.edu/concepts

9. www.businessdictionary.com/definition/organizational-culture.html,

10. http://www.securitygovernance.net/resources/045.pdf

11. www.stratfor.com/weekly/20101018_germany_and_failure_multiculturalism.

12. www.stratfor.com/weekly/20100719_geopolitics_nationalism_and_dual_citiz enship

13. www.normangirvan.info/tag/mervyn-claxton/

14. http//www.humansecurity.com/documents/RBF_cultureidsecurity.pdf

15. http://oxforddictionaries.com/definition/institution

16. http://www-pub.iaea.org/MTCD/publications/PDF/Pub1472_web.pdf

17. www.irchina.org

18. http://turin.sgir.eu/uploads/Williams-security_cultures\%20SGIR\%20paper $\% 20$ Sept $\% 202007 . p d f$

19. Институт за стандардизацију Републике Србије, www.iss.rs

20. НАТО-агенција за стандардизацију, htpp://nsa.nato.in 


\section{Биографија аутора}

Мр Светлана Станаревић рођена је у Ковину 28. маја 1968. Основну и средњу школу завршила је као добитник Вукове дипломе. Факултет одбране и заштите Универзитета у Београду (сада Факултет безбедности), завршила је 1992. године, чиме је стекла стручни назив професор одбране и заштите.

У априлу 2002. године изабрана је за сарадника у звању асистент-приправник на предмету Системи безбедности, на Факултету цивилне одбране у Београду (Факултет безбедности), где и сада ради у звању асистента. Магистарске студије је завршила на Факултету цивилне одбране (смер безбедности) са просечном оценом 9,00. Магистарску тезу под називом Могућности локалне заједнице у остваривању безбедности школе - случај општине Палилула одбранила је 23. 2. 2007, чиме је стекла академски назив магистра наука одбране, безбедности и заштите - смер наука безбедности. Исте године добила је од општине Палилула Значку заштите $u$ безбедности за успешно реализован пројекат истраживања стања безбедности у школама на територији градске општине Палилула током 2005/06. године.

Кандидаткиња је до сада учествовала у више пројеката који се баве истраживањем људске безбедности, безбедности у локалној заједници, безбедношћу школе и безбедносном културом. Професионално је, између осталог, била ангажована у изради Националне стратегије за младе (2007/08), Акционог плана за примену Националне стратегије за младе (2008) и Закона о младима (2012) као члан консултативне групе. Објавила је, у својству аутора или коаутора, неколико монографија, више радова у домаћим зборницима и часописима, и учествовала у раду неколико међународних конференција. 


\section{Изјава о ауторству}

Потписана: мр Светлана Станаревић

број уписа:

\section{Изјављујем}

да је докторска дисертација под насловом:

\section{Концепт безбедносне културе и претпоставке његовог развоја}

- резултат сопственог истраживачког рада,

- да предложена дисертација у целини ни у деловима није била предложена за добијање било које дипломе према студијским програмима других високошколских установа,

- д да су резултати истраживања коректно наведени и

- да нисам кршила ауторска права и користила интелектуалну својину других лица.

Потпис докторанда:

У Београду, 28. августа 2012.

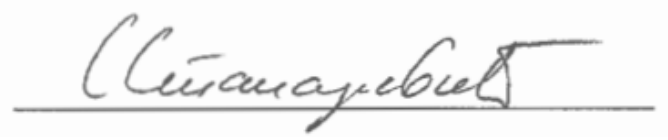




\section{Изјава о истоветности штампане \\ и електронске верзије \\ докторског рада}

Име и презиме аутора: мр Светлана Станаревић

Број уписа:

Студијски програм: науке безбедности

Наслов рада: Концепт безбедносне културе и претпоставке његовог развоја

Ментор: др Миленко Бодин, доцент

Потписани: мр Светлана Станаревић

Изјављујем да је штампана верзија мог докторског рада истоветна с електронском верзијом коју сам предала за објављивање на порталу Дигиталног репозиторијума Универзитета у Београду.

Дозвољавам да се објаве моји лични подаци везани за добијање академског звања доктора наука, као што су име и презиме, година и место рођења и датум одбране рада.

Ови лични подаци могу се објавити на мрежним страницама дигиталне библиотеке, у електронском каталогу и у публикацијама Универзитета у Београду.

У Београду, 28. августа 2012.

Потпис докторанда:

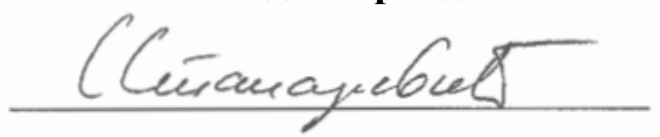




\section{Изјава о коришћењу}

Овлашћујем Универзитетску библиотеку „Светозар Марковић“ да у Дигитални репозиторијум Универзитета у Београду унесе моју докторску дисертацију под насловом:

\section{Концепт безбедносне културе и претпоставке његовог развоја,} која је моје ауторско дело.

Дисертацију са свим прилозима предала сам у електронском формату погодном за трајно архивирање.

Mojy докторску дисертацију похрањену у Дигитални репозиторијум Универзитета у Београду могу да користе сви који поштују одредбе садржане у одабраном типу лиценце Креативне заједнице (Creative Commons) за коју сам се одлучила.

1. Ауторство

2. Ауторство - некомерцијално

(3.)Ауторство - некомерцијално - без прераде

4. Ауторство - некомерцијално - делити под истим условима

5. Ауторство - без прераде

6. Ауторство - делити под истим условима

У Београду, 28. августа 2012.

Потпис докторанда

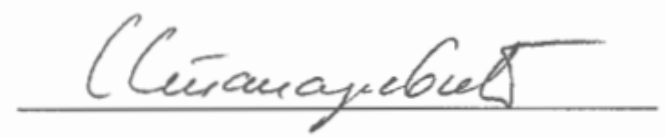

